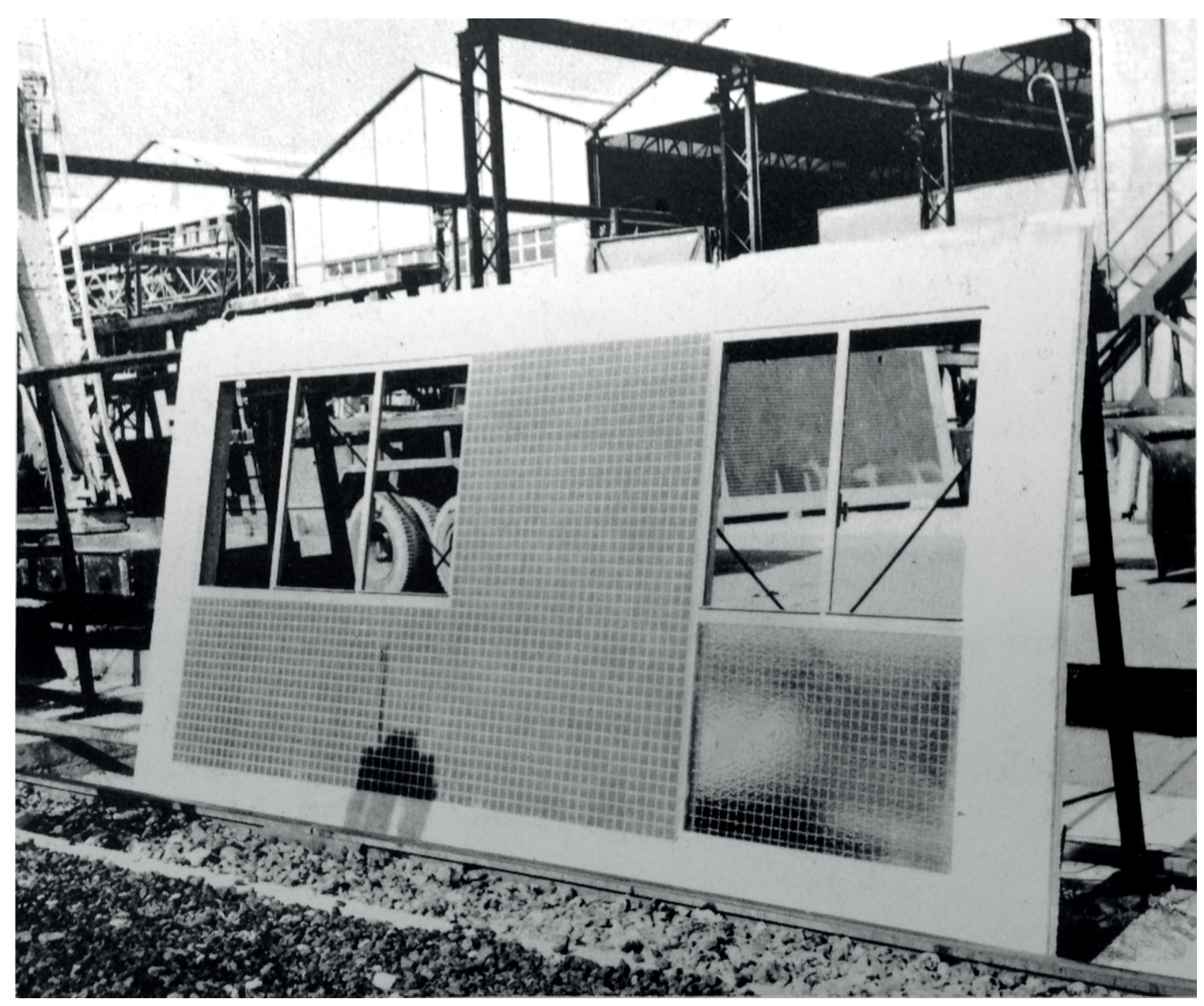

O DEBATE SOBRE A INDUSTRIALIZAÇÃ̃ DA ARQUITETURA NA FAUUSP DURANTE AS DÉCADAS DE 1950 E 1960

Natália Maria Gaspar

ORIENTADOR

Prof. Dr. Paulo Eduardo Fonseca de Campos 
Natália Maria Gaspar

\section{O DEBATE SOBRE A INDUSTRIALIZAÇÃO DA ARQUITETURA NA FAUUSP DURANTE AS DÉGADAS DE 1950 E 1960}

Dissertação apresentada à Faculdade de Arquitetura e Urbanismo da Universidade de São Paulo como requisito para a obtenção do título de mestre em Arquitetura e Urbanismo.

ÁREA DE CONGENTRAÇÃO

Design e Arquitetura

ORIENTADOR

Prof. Dr. Paulo Eduardo Fonseca de Campos

SÃo PAUlo, 2016 

Autorizo a reprodução e divulgação total ou parcial deste trabalho, por qualquer meio convencional ou eletrônico, para fins de estudo e pesquisa, desde que citada a fonte.

Email da autora: gaspar.natalia@gmail.com

\footnotetext{
Gaspar, Natália Maria

G249d O DEBATE SOBRE A INDUSTRIALIZAÇÃO DA ARQUITETURA NA FAUUSP DURANTE AS déCAdas de 1950 E 1960 / Natália Maria Gaspar. -- São PaUlo, 2016. 180 P. : IL.

Dissertação (Mestrado - Área de Concentração: Design e ArquitetuRA) - FAUUSP.

Orientador: Paulo Eduardo Fonseca de Campos

1.Arquitetura moderna 2.História da arquitetura 3.Design (Estudo E ENSINO 4.PROJETO DE ARQUiteTURA (ESTUdo E ENSINO) 5.INDUSTRIALIZAÇÃO DA CONSTRUÇÃO 6.SisTEMAS E PROCESSOS CONSTRUTIVOS 7.INDUSTRIALIZaÇão da ARquitetura 8.Faculdade de Arquitetura e Urbanismo /USP I.TÍTULO
}

CDU 72.036

Imagem da capa: painel-parede da patente Raymond-Camus.

Fonte: Procedimientos Raymond Camus. 200.000 mil alojamientos terminados en el mundo, 23 fabricas trabajando en 10 paises. S.l.: S.N.,1971. 



\section{Agradecimentos}

Antes de tudo, aos meus pais, Cida e Vagner, sem os quais eu não teria chegado aqui.

Ao Paulo Eduardo Fonseca de Campos, que aceitou me orientar mais uma vez, agradeço especialmente pela amizade e confiança.

Às professoras Cibele Haddad Taralli e Maria Lúcia Caira Gitahy, membros de minha banca de qualificação, por suas observações e sugestões para o desenvolvimento da pesquisa.

À Tatiana Sakurai, pelas conversas animadas sobre arquitetura, sobre a pós-graduação e sobre o tema da minha pesquisa.

Aos funcionários da FAUUSP que me orientaram na localização tantos documentos. Geralda e Silvia, do Departamento de História. Francisca, Falcão, Eliane, Rogério, Sadi e Luciene, do Departamento de Projeto. Iliete Maria de Franco Arruda. Magáli Cangussu, chefe da assistência acadêmica. Rejane, Lucila, Dina e Maria José, das bibliotecas da FAUUSP.

Ao meus amigos e colegas de trabalho na Escola SENAI "Orlando Laviero Ferraiuolo" pelas ótimas conversas sobre a construção civil e pelo incentivo. Carlos Eduardo Machado de Oliveira, Célia Cabrino, Aline Kemp, Alex Cardoso, Augusto Camacho e João Batista da Silva.

Aos amigos Pedro Nakamura, Higor Carvalho, Renata Siqueira, João Busko, Rodrigo Agostini, Samira Chaim, Salete Marra e Fernando Tena pela amizade e pelo incentivo na conclusão do trabalho.

Pelo carinho e, principalmente, pela cumplicidade, agradeço ao Gabriel Fernandes. 



\section{RESUMO}

\section{GASPAR, N.M. O debate sobre a industrialização da arquitetura na FAUUSP}

durante as décadas de 1950 e 1960. 2016. 180 f. Dissertação (Mestrado). Faculdade de Arquitetura e Urbanismo, Universidade de São Paulo, 2016.

Com o intuito de estudar a industrialização da arquitetura nas décadas de 1950 e 1960, definimos como objeto de estudo a FAUUSP e o que era debatido por sua comunidade, professores e estudante, sobre o tema durante os anos que vão desde sua fundação em 1948 até 1970. Por meio da Reforma Curricular de 1962, que marcou o amadurecimento da proposta do ensino de arquitetura orientado pelo movimento moderno, e estimulados pelo período desenvolvimentista por que passava o Brasil no final dos anos 1950, a comunidade docente implantou um Sequência de Disciplinas de Desenho Industrial que resultou, ainda que numa proposta legítima, na formação de profissionais da arquitetura com perfil para o trabalho na indústria de bens de consumo. Por comparação, e entendendo que a industrialização da arquitetura é um importante componente da origem da arquitetura moderna, desejamos compreender se o desenho industrial, da mesma maneira, havia penetrado também no ensino de projeto de arquitetura. Portanto, as disciplinas de projeto de arquitetura incorporaram essas ideias depois da reforma, até o final dos anos 1960? Se sim, como o desenho industrial para a produção de componentes e sistemas construtivos de arquitetura era trabalhado em sala? Havia ainda um imaginário sobre a industrialização da arquitetura, latente nas revistas e nas memórias de viagem, incentivado principalmente pelos esforços de reconstrução do pós-guerra. A imagem do grande painel de concreto, içado por grua, representando um canteiro mecanizado e avançado (ou pouco precário) era um paradigma a ser alcançado. Ao mesmo tempo, os mesmos docentes da escola debatiam nas instituições da categoria, como o IAB, nos congressos brasileiros de arquitetos e nas revistas a necessidade de industrializar a arquitetura para a produção de habitação. Parecia que a industrialização da arquitetura, a ser alcançada pela ação político-profissional do arquiteto no desenvolvimento nacional, ainda estava longe de se concretizar.

Palavras-chave: 1.Arquitetura moderna 2.História da arquitetura 3.Design (Estudo e ensino 4.Projeto de arquitetura (Estudo e ensino) 5.Industrialização da construção 6.Sistemas e processos construtivos 7.Industrialização da arquitetura 8.Faculdade de Arquitetura e Urbanismo 



\section{Abstract}

GASPAR, N. M. Debates on architecture industrialization in FAUUSP in 1950s and 60s. 2016. XX p. Thesis (Master of Science in Architecture) - Faculdade de Arquitetura e Urbanismo, Universidade de São Paulo, 2016.

Aiming at the study of architecture industrialization in 1950s and 60s decades, FAUUSP, as well as what was debated on this matter by its faculty and students since its inception in 1948 until the 1970s, was defined as our research subject. By means of 1962 curriculum reform, which strengthened the modern movement-oriented teaching proposals, and stimulated the developmentist scenario Brazil was experiencing by that time, the school's faculty implanted a sequence of Industrial Design studio courses that resulted, although based on a legitimate proposal, on the formation of architects whose professional profiles were targeted on consumer goods industry. By comparison, and knowing that architecture industrialization is a key component of modern architecture origins, we aim to understand wether industrial design penetrated or not architectural design studios as well as industrial design ones. As such, did design studio courses incorporate those ideas after curriculum reform, until the end of the 60s? If yes, how industrial design aimed at component production and building systems development were dealt with during classes? There was still an architecture industrialization imaginary, latent on magazines and trip memories, mainly encouraged by European postwar rebuilding efforts. Big crane-lifted concrete panels images, representing a mechanized and advanced building site (or else a less precarious one), was a paradigm to be reached. At the same time, the very same professors debated the need of industrializing mass housing production in class institutions (as the Brazilian Architects Institute), in professional congresses and in the magazines. It seemed that architecture industrialization, to be reached by the architects' professional-political action, was still far to be reached.

Keywords: 1.Modern architecture 2.Architectural History 3.Design (Studies and Education) 4.Architectural (Design Studies and Education) 5. Building Industrialization 6. Building Processes and Systems 7.Architecture industrialization 8. Faculdade de Arquitetura e Urbanismo/USP 



\section{SUMÁRIO}

INTRODUÇÃOO, 1

OBjeTIVOS DA PESQUiSA, TRAJETÓRIA E MÉTODOS DE TRABALHO, 6

1 Considerações iniciais sobre o desenho industrial na ArQuitetura, 11

As ideias de industrializaÇÃo nos Congressos de ArQuitetos, 25

Os Congresso Brasileiros de Arquitetos, 25

Os Congressos da União Internacional de Arquitetos, 30

O LEGAdO DA REVOLUÇÃO MENTAL DE TAYLOR NA ARQUITETURA, 33

2 A IndUStrialização No ENSINO DE PROJETO NA FAUUSP, 41

O PRIMEIRO REGULAMENTO DA FAUUSP, 45

De 1948 a 1955, 46

Lina Bo Bardi na FAUUSP, 54

De 1956 a 1962, 58

DePOIS DA REFORMA DE 1962, 70

As disciplinas do Departamento de Tecnologia, 71

As disciplinas do Departamento de Projeto, 77

3 As ReVistas de aRQUITETURA E AS REFERÊNGIAS DO PERÍODO, 85

Publicidade, vitrines E EMPRESAS BRASILEIRAS, 90

Habitat, 90

O Dirigente Construtor, 92

Acrópole, 95

Planos, HabitaÇão POPUlaR E INDUSTRIALIZAÇÃO NAS REVISTAS, 99

$\mathrm{O}$ BNH, o PNH e as críticas à produção em massa de habitação, 99

O GTH - Grupo Técnico da Habitação, 101

O CBC - Bouwcentrum, o Centro Brasileiro da Construção, 102

O CIPHAB - o Centros de Coordenação Industrial para o Plano Habitacional, 105

O Catálogo Brasileiro da Construção, do IAB, 108

REFERÊNCIAS DE ARQUITETURA NAGIONAL E INTERNACIONAL INDUSTRIALIZADAS, 113 Os catálogos de edifícios patenteados, 116

Cuba, 118

Gonclusão: As PROPOSTAS PREGÁRIAS DE INDUSTRIALIZAÇão POSSíVEL, 139

REFERÊNGIAS BIBLIOGRÁFIGAS, 153 

INTRODUÇÃO 

Em 2011, quando retornei para a FAUUSP para realizar uma disciplina de pós-graduação na condição de estudante especial, tinha vontade de conhecer mais sobre arquitetura industrializada, exemplos do que já foi feito, como desenhar peças, como resolver juntas, quais os materiais adequados e como utilizá-los. Esses assuntos, especialmente o desenho industrial de componentes e os aspectos mais pragmáticos sobre a característica e a resistência dos materiais, eram (e acredito que ainda sejam) bem pouco abordados em um curso de arquitetura, inclusive na FAUUSP.

Além disso, na disciplina que cursei, AUH-5758 História Social do Design no Brasil, do Prof. Dr. Marcos da Costa Braga, tive contato com o doutorado de Juliano Pereira $\left(2009^{1}\right.$ ), que apresenta uma discussão em torno da Reforma Curricular de 1962, da implantação da Sequência de Desenho Industrial e do ensino de desenho industrial para os arquitetos naqueles anos, e com o artigo de Renata Siqueira e Marcos Braga (2009) também sobre o mesmo tema ${ }^{2}$.

Por comparação, interessou-me entender o que se falava sobre industrialização da arquitetura naquelas disciplinas de desenho industrial, no que Marcos Braga sugeriu que eu estudasse o que se falava sobre o desenho industrial, ao contrário, nas disciplinas de projeto de arquitetura.

A partir de alguns poucos documentos localizados no Departamento de Projeto da FAUUSP à época, realizei a monografia para a disciplina, que também serviu como projeto de pesquisa para esta dissertação.

Durante a banca de qualificação, a professora Maria Lúcia Caira Gitahy nos direcionou uma

1 PEREIRA, Juliano Aparecido. Desenho industrial e arquitetura no ensino da FAU-USP (1948-1968). São Carlos: EESC-USP, 2009. Orientação de Renato Luiz Sobral Anelli.

2 SIQUEIRA, Renata Monteiro; BRAGA, Marcos da Costa. FAU-USP, 1962: a implementação do Grupo de Disciplinas de Desenho Industrial no curso de Arquitetura e Urbanismo. Anais em meio digital do 5o Congresso Internacional de Pesquisa em Design - CIPED. Bauru: UNESP, 2009. 
pergunta que, no momento, não foi propriamente respondida: por que estudar o tema da industrialização justamente no ensino de projeto?

Foi só depois da qualificação, no entanto, que conseguimos elaborar uma justificativa adequada para este estudo. A escola, a instituição como conhecida hoje, seu formato e finalidades, é um instrumento ideológico de formação e transmissão de ideias, seja para as classes dominantes, seja para as classes trabalhadoras.

Além disso, a Reforma Curricular de 1962, que incluiu uma sequência de disciplinas de desenho industrial em sua grade curricular, teve importante papel na formação dos arquitetos e na definição da profissão nos anos 1960. E, mesmo tendo investido na formação de um profissional para a indústria de bens de consumo durante os anos 1960, conforme apresentado por Pereira (2009), a escola pouco ou nada investiu na formação de um profissional para a industrialização da arquitetura na mesma época, conforme já tínhamos averiguado brevemente durante a disciplina AUH-5758 História Social do Design no Brasil, apesar da industrialização da arquitetura ser um importante componente da ideologia da arquitetura moderna (Guillén, 2009); dos temas afins, como a "coordenação modular", já fazerem parte do vocabulário daqueles arquitetos docentes à época, e da presença de um rico imaginário sobre a industrialização no dia-a-dia daquela comunidade, especialmente através das revistas especializadas.

A análise das ementas das disciplinas de projeto desde 1948 até 1970 sugerem que os docentes pouco ou nada se aproximaram de questões de projeto de componentes para a construção civil e, mesmo que os discursos e intenções a respeito da industrialização da arquitetura moderna não tenham se viabilizado na prática, naquele momento, pode-se verificar brevemente não só que os estudantes passaram também a mobilizar os temas afins da industrialização da arquitetura no final da década de 1960 e início de 1970, mas que uma outra industrialização de componentes acontecia em outras instâncias e até mesmo alimentaram a produção informal de habitações.

Portanto, como a ideia do desenho industrial foi sendo incorporada nas disciplinas da FAUUSP até culminar na reforma de 1962? E como as disciplinas de projeto de arquitetura incorporaram essas ideias depois da reforma, até o final dos anos 1960? Qual era o imaginário sobre a arquitetura industrializada que chegava até a comunidade e o que se entendia por industrialização da arquitetura naquele momento?

Essas foram algumas questões que nortearam nossa pesquisa, uma oportunidade de averiguar 
com mais cuidado a presença da a industrialização da arquitetura tanto no ensino de projeto da FAUUSP como do lado de fora, nos congressos de arquitetos e nas revistas especializadas de arquitetura, pois trata-se de um momento chave par a entender certas tendências na história da arquitetura e do design brasileiros nos nas últimas décadas.

No primeiro capítulo desta dissertação, tentamos nos aproximar da industrialização da arquitetura por meio de três episódios que, acreditamos, apresentam um panorama sobre como o tema aparecia relacionado a outros temas também importantes no período estudado (1948 a 1970): a "questão da habitação" que mobilizava os debates entre os arquitetos sobre uma certa função social destes no desenvolvimento nacional; os diálogos que os arquitetos, por meio das associações de categoria profissional travavam com órgão governamentais, especialmente o $\mathrm{BNH}$; e uma certa atitude voluntariosa em projetar componentes industriais concorrendo com um mercado de construção civil razoavelmente já estabelecido à época, cujos produtos eram fartamente veiculados pelas revistas que os mesmos arquitetos já acessavam.

Também apresentamos brevemente como nos Congressos o tema da industrialização era debatido.

Neste capítulo tentamos ainda retomar, brevemente, alguns pontos sobre como a industrialização passa a fazer parte do vocabulários dos arquitetos. Não foi nossa intenção, no entanto, um debate sobre as causas da arquitetura moderna nem sobre as teorias da administração científica que se rebateram na ideologia do movimento moderno. Esse assunto é bem desenvolvido por Guillén (2009).

No segundo capítulo apresentamos uma leitura das ementas das disciplinas da FAU, em que tentamos identificar se e como o tema da industrialização vinha sendo incluído nestas desde a 1948, passando pela Reforma Curricular de 1962 até 1970. Outras disciplinas que também se aproximavam do tema foram consideradas no texto. Era nossa intenção fazer uma comparação da vida profissional dos docentes das disciplinas elencadas com aquilo que aparentemente estavam trabalhando em sala de aula e por isso tentamos reconstruir a grade curricular da FAUUSP durante o período estudado e conseguimos localizar muitos docentes que ministraram aula nas várias disciplinas ou cadeiras.

No entanto, há um significativo vazio sobre como trabalhavam, se é que trabalhavam, com questões de industrialização em seu projetos naquelas décadas de 1950 e 1960. Os textos 
elaborados por vários daqueles docentes, ou os trabalhos acadêmicos sobre eles, pouco ou nada dizem sobre a industrialização da arquitetura. O pouco que foi encontrado, muitas vezes nas revistas especializadas, foi apontado no capítulo seguinte. Talvez Ariosto Mila e Luiz Cintra do Prado tenham contribuído decisivamente para despertar o interesse de muitos estudantes para a industrialização da arquitetura, paralelamente ao incentivo que era feito no sentido do desenho industrial de bens de consumo.

No capítulo 3, diante do vazio encontrado sobre o tema da industrialização da arquitetura entre os docentes, partimos em busca de referências sobre industrialização da arquitetura nas revistas especializadas de arquitetura e engenharia, fontes externas onde encontramos farto material sobre as empresas brasileiras que já comercializavam produtos corriqueiros da construção civil desenvolvidos aqui. Em alguns artigos, localizamos até mesmo empresas que importavam tecnologia ou se inspiravam nos referenciais internacionais.

Além disso, foi opção nossa não transformar esse capítulo em um mostruário da produção industrializada dos vários países onde a industrialização de habitação popular era realidade à época, durante a reconstrução no pós-guerra. Tentamos circunscrever nossa leitura aos artigos das revistas brasileiras selecionadas: O Dirigente Construtor, Habitat e Acrópole.

No capítulo de conclusão, antes de retomar aquilo que foi exposto ao longo da dissertação, apresentamos brevemente uma pequena produção de estudantes da FAUUSP, formados no final dos anos 1960 e início dos anos 1970, em que dialogam não só com a industrialização da arquitetura mas também com a autoconstrução. Entendemos que, dado o fracasso apontado pelas políticas habitacionais no final dos anos 1960 e a pouca ação político-profissional com que se deparavam os arquitetos na solução dos problemas urbanos e sociais, era a arquitetura possível, tanto no nível do projeto dos novos arquitetos como na realidade de quem autopromovia habitação, que mobilizava e consumia produtos industrializados disponíveis no varejo.

Por fim, foi nossa opção não relacionar a fundação da FAUUSP e a "evolução" de seu currículo com a Bauhaus, que existiu na Alemanha entre 1919 a 1933, ou com os ateliês artísticos Vkhutemas/Vkhutein, que existiram na Rússia entre 1920 a 1930.

Recusamos a ideia de que a essas experiências tenham servido como modelos para a organização do ensino na FAUUSP. A Bauhaus era um referência à época mas nunca serviu como modelo para a FAUUSP, fundada com o propósito de consolidar uma profissão autônoma da engenharia, e não de formar profissionais para a produção industrial. 
Os ateliês artísticos Vkhutemas/Vkhutein foi uma experiência que se manteve ignorada por muito tempo e nem é citada nas ementas de história da arquitetura do período estudado, ao contrário da Bauhaus que sempre representou um tópico a ser apresentado em aula. MIGUEL (2006) comenta que se a herança da Bauhaus foi cuidadosamente conservada, catalogada, classificada, analisada, publicada, a herança da Vkhutemas/Vkhutein foi por longo tempo ignorada. 


\section{Objetivos da pesquisa, trajetória e métodos de trabalho}

\section{Objeto de estudo}

O objeto de estudo definido para esta dissertação é o conjunto de discursos sobre a industrialização da arquitetura da segunda fase curricular de formação do arquiteto na FAUUSP, após a Reforma Curricular de 1962. Definimos então o período que vai desde a fundação da escola, 1948, até o final da década em questão, 1970, para entender melhor o objeto de estudo.

Apesar do pouco material encontrado nas ementas de disciplinas e na produção da maior parte dos docentes do período, acabamos por reunir um conjunto de discursos encontrados por meio das revistas na tentativa de entender se havia e quais eram as referências sobre industrialização, daí o conjunto de discursos que conseguimos reunir e estudar são tanto internos como externos à FAUUSP, mas dizem respeito ao período que vai de 1948 a 1970.

\section{Objetivos}

Os objetivos iniciais propostos para a pesquisa eram os seguintes:

(1) Estabelecer um panorama crítico e abrangente dos elementos constituintes do discurso sobre a industrialização da arquitetura presente na FAUUSP no contexto da Reforma Curricular de 1962

(2) Contribuir ao estudo do papel da industrialização e dos discursos da industrialização no desenvolvimento da arquitetura à década de 1960, considerando inclusive a prática profissional de seus principais atores, ou seja, os docentes desta FAUUSP à época.

(3) Contribuir ao estudo do papel desempenhado pelas experiências nacionais e internacionais de industrialização e pré-fabricação da arquitetura na consolidação do conjunto de discursos recorrentes na FAUUSP durante a década de 1960.

\section{Métodos de trabalho}

(1) Levantamento de bibliografia que apresente o estado da arte sobre o estudo e o discurso da industrialização da arquitetura na FAUUSP da década de 1960:

(2) Levantamento de bibliografia analítica e crítica a respeito da produção do corpo docentes e discente, à época, embalada pelo discurso da industrialização 


\section{da arquitetura.}

Infelizmente não localizamos bibliografia que trate especificamente dos objetos e objetivos definidos nesta pesquisa. A bibliografia consultada, entre mestrados e doutorados sobre a obras dos docentes e ex-alunos personagens da narrativa, apontam pouco ou nada sobre o entendimento que cada um desses personagens tinha a respeito da industrialização.

A partir daí decidiu-se iniciar a exploração de algumas dessas revistas do período a fim de identificar se havia indícios de um debate e de um imaginário a respeito do tema e o que se encontrou foi material abundante, muitas vezes com indicações indiretas ao tema da industrialização. O material coletado não aponta somente um discussão que parte dos docentes, mas também de personagens externos à FAUUSP, tanto publicidade de produtos industrializados já largamente utilizados à época, como referências à produção industrializada internacional tidas como paradigmáticas.

(3) Levantamento de programas, ementas e docentes das disciplinas de Projeto de Edifícios ministradas durante a década de 1960: este levantamento foi realizado no arquivo do Departamento de Projeto da FAUUSP, que possui poucos documentos que serviam para nossa pesquisa, e no Departamento de História, onde se encontrou uma coleção quase completa e bem preservada das ementas do período estudado. Consideramos para a pesquisa que as ementas foram razoavelmente seguidas e aplicadas pelos docentes.

O Departamento de Tecnologia somente possui documentos a partir de 1971 e por isso não havia lá material que nos interessasse para a pesquisa. Por curiosidade ainda fizemos uma busca por documentos no Instituto Lina Bo e P.M. Bardi, a fim de verificar como a Lina Bo Bardo se relacionou com a FAUUSP nos dois anos em que foi docente (1955 e 1956) e encontramos alguns documentos que indicam os docentes das várias disciplinas daqueles anos.

(4) Levantamento do corpo discente de cada disciplina de Projeto de Edifícios à época a fim de se conseguir possíveis trabalhos discentes preservados como exemplo do resultado didático obtido: Não foi possível realizar um levantamento de estudantes por disciplinas, mas tivemos autorização da escola para acessar a lista dos arquitetos formados na escola até o ano de 1975 (incluídos aí aqueles primeiranistas em 1970), fornecida pela Seção de Alunos da escola.

(5) Aplicação de entrevistas com professores e ex-professores, já aposentados, que possam contribuir com seu relato sobre as discussões da industrialização da arquitetura à data proposta; 
(6) Aplicação de entrevistas com ex-alunos das disciplinas do período que possam contribuir com lembranças a respeito daquelas discussões;

Foi possível realizar entrevista com as seguintes pessoas:

- Paulo Júlio Valentino Bruna, arquiteto formado em 1963 pela FAUUSP e docente aposentado do Departamento de História que nos concedeu entrevista em 06 de março de 2015.

- Marlene Picarelli, arquiteta formada 1957 pela FAUUSP e docente aposentada do Departamento de Projeto que nos concedeu entrevista em 13 de março de 2015.

- Anna Maria Carboncini Masini, diretora do Instituto Lina Bo e P.M. Bardi, que nos concedeu entrevista em 13 de março de 2015.

- Jon Andoni Vergareche Maitrejean, arquiteto formado em 1953 pela FAUUSP que nos concedeu entrevista em 12 de setembro de 2015.

- Lucio Grinover e Marlene Picarelli, que nos concederam entrevista em 18 de setembro de 2015. Lúcio Grinover é arquiteto formado em 1957 pela FAUUSP.

- Nestor Goulart Reis Filho, arquiteto formado em 1955 pela FAUUSP que nos concedeu entrevista em 08 de abril de 2015

- Maria Giselda Cardoso Visconti, arquiteta formada em 1958 pela FAUUSP que nos concedeu entrevista em 09 de dezembro de 2015.

Fizemos contato com outros docentes e ex-alunos do período mas que, por motivo de saúde ou de agenda, não puderam nos conceder entrevista. Ainda realizamos entrevistas exploratórias e não registradas com os docentes Antônio Carlos Sant'Anna e Cibele Haddad Taralli, sobre suas impressões na época da graduação, 1970 - 1974.

Durante as entrevistas solicitamos aos entrevistados trabalhos ou documentos daquela época, mas nenhum deles pode nos ajudar pois não possuíam mais documentos que nos diziam respeito. Por fim, as entrevistas não foram transcritas, somente fichadas para nossa utilização, e não as apresentamos ao final.

(7) Levantamento e leitura de textos produzidos à época tanto pelo corpo docente quanto pelo corpo discente a respeito do tema;

(8) Levantamento da produção arquitetônica dos docentes, a fim de averiguar a 
trajetória dos professor es de projeto de arquitetura e o fato de não terem estabelecido uma relação mais orgânica com as poucas empresas de préfabricação ou o fato de não terem sensibilizado as empresas de construção civil que, à época, produziam edifícios de habitação para a classe média;

Apesar do tema nos parecer latente no período, encontramos um vazio de textos ou documentos entre os docentes que falasse diretamente sobre a industrialização da arquitetura. Foi principalmente nas revistas onde localizamos textos em que os docentes discutem, indiretamente, o tema da industrialização da arquitetura ou da construção civil. Como se verá a seguir, artigos com depoimentos de Vilanova Artigas, Paulo Mendes da Rocha, Lúcio Grinover, Oswaldo Correia Gonçalves, ou textos assinados por Abelardo Riedy de Souza e Eduardo Corona. são apontados ao longo da nosssa narrativa.

Entre os trabalhos acadêmicos dos docentes, talvez os textos de Ariosto Mila sejam os únicos em que algum docente da FAUUSP, no período estudado, tenha escrito sobre o tema. E entre alguns mestrados e doutorados sobre a vida profissional de docentes e ex-alunos da FAUUSP há um vazio a respeito de como o sujeito em questão lidava com a industrialização. Talvez os trabalhos sobre Millan, escrito por Faggin $(1987,1994)$ e Matera (2006) sejam os únicos que conseguem entrar no mérito do entendimento do arquiteto sobre o nosso tema. 
Gapítulo 1

Considerações INIGIAIS SObRe O DESENHO INDUSTRIAL NA

Arquitetura 
Em maio de 1966, O Dirigente Construtor publicava um caderno especial intitulado "Arquitetura de Interiores" em meio a "Projetos, Obras, Técnicas, Materiais e Administração da Indústria da Construção" ${ }^{\prime 4}$, temas aos quais a revista estava dedicada. Ao contrário de parecer contrastante com os temas da revista, o próprio artigo justificava como a Arquitetura de Interiores não passava de uma nomenclatura para fácil delimitação de um campo de atuação que estava na verdade completamente inserido no entendimento de projeto total: da necessidade do projeto de uma praça, das ruas, da cidade estarem em coerência com o projeto da casa, de seus compartimentos, de seus equipamentos e objetos, de seu interior com seu exterior. O espaço interior deveria ser igualmente planejado para quem nele vai viver, não fazendo sentido a distinção entre o projeto da casa e outro para seu interior. As várias escalas da obra arquitetônica deveriam ser pensadas simultaneamente.

Segundo a revista, ainda que o termo Arquitetura de Interiores não fosse muito feliz, sua necessidade residia na contraposição da atividade à mera decoração, entendida como a composição plástica de um mosaico aleatório, de arranjos supérfluos, enquanto a Arquitetura de Interiores era a organização dos ambientes segundo uma função específica a ser desempenhada ali, conforme as necessidades dos novos tempos. $\mathrm{O}$ artigo cita, entre outros, a opinião de Paulo Mendes da Rocha e Vilanova Artigas, docentes da FAUUSP à época, sobre o papel do arquiteto nos projetos de interiores.

$\mathrm{O}$ artigo toca nas opções construtivas disponíveis à época para uma arquitetura que pretendia dar conta também do aspecto interior da edificação, como materiais usados em seu aspecto

3 Arquitetura de interiores. O Dirigente Construtor. São Paulo, v. 2, n. 7, p. 33-59, mai. 1966. Caderno Especial.

4 Esta era parte da informação contida na contracapa de todos os números da revista O Dirigente Construtor, explicando o perfil e funcionamento da publicação: "O DIRIGENTE CONSTRUTOR, revista de Projetos, Obras, Técnicas, Materiais e Administração da Indústria da Construção, é enviada aos arquitetos, engenheiros, diretores e técnicos ligados ao planejamento, execução e fiscalização de obras civis de empresas particulares, de companhias de serviços públicos e de departamentos de obras dos governos Federal, Estaduais e Municipais. Outros interessados podem adquirir exemplares avulsos a $\mathcal{N C r} \$ 2,00$, números atrasados a $\mathcal{N C r} \$ 2,50$ e assinaturas por 1 ano a $\mathcal{N C r} \$ 15,00,2$ anos a $\mathcal{N C r} \$ 23,00$ e 3 anos a $\mathcal{N C r} \$ 30,00$. Assinaturas para o Exterior: EUA: via aérea US\$20,00; via comum US\$8,00. Pagamentos somente por cheques bancários visados, pagáveis na praça de São Paulo". 
natural e bruto, como o concreto aparente, o vidro e a madeira e materiais que seriam aplicados como revestimento sobre alvenarias, como lâminas resinadas de madeira ou painéis cerâmicos. Neste ponto, o texto acusava a inexistente padronização dimensional dos elementos que, com dificuldade, eram empregados simultaneamente ou poderiam ser substituídos entre si, motivos pelos quais - apesar de citar a parceria entre o arquiteto Sérgio Bernardes e a empresa Eternit no projeto de uma telha para coberturas planas, exemplarmente apresentado sobre como o arquiteto poderia contribuir com as indústrias era urgente um maior entrosamento entre a indústria e o arquiteto que, conforme Lúcio Costa, citado no artigo, era o profissional mais indicado para "introduzir características culturais no processo industrial" e "reformular desde o objeto cotidiano até o edificio e os espaços urbanos" de um país que se modernizava. Continuava a revista dizendo que o arquiteto desempenharia seu papel, via de regra, ora na categoria de criador de sistemas construtivos pré-fabricados ora na categoria de projetista, aplicando produtos de catálogo e, para tanto, era necessária a formação de quadros preparados para intervir no campo do desenho industrial. Havia, nas entrelinhas, um tom de insatisfação dos arquitetos em relação à pouca valorização de sua possível contribuição profissional e com a pouca racionalização da construção - isso dentro de uma revista que apresentava uma construção civil com um perfil bastante organizado e avançado em comparação ao que era apresentado pelas outras revistas especializadas em arquitetura e construção civil.

Lúcio Grinover, presidente da Associação Brasileira de Desenho Industrial, prestando depoimento para a revista, no mesmo artigo, lembrava que o desenho industrial já era ensinado em várias entidades entre as quais a Escola Superior de Desenho Industrial, no Rio de Janeiro, e a Faculdade de Arquitetura e Urbanismo da Universidade de São Paulo — onde Lúcio Grinover já lecionava desde 1958 - por meio de uma sequência de disciplinas de Desenho Industrial de seu Departamento de Projeto.

Não custa lembrar que tinha sido recentemente que a FAUUSP havia reformado seu currículo, implantando disciplinas de desenho industrial e de comunicação visual. Muitos dos exercícios desenvolvidos pelos estudantes de arquitetura nestas disciplinas, inclusive, foram dispostos nas páginas da revista, ilustrando a fala de Lúcio Grinover. Numa observação mais cuidadosa, no entanto, os exercícios não tratavam de componentes industrializados de arquitetura: ainda que numa proposta legítima, tratava-se de projetos de bens de consumo, objetos comuns de uso cotidiano que não se relacionavam com algum projeto específico de arquitetura de interior. 
Capa da edição do Caderno Especial sobre Arquitetura de interiores.

O Dirigente Construtor. São Paulo, v. 2, n. 7, mai. 1966.

Caderno Especial Arquitetura de interiores, sobre o desenho industrial, em que é discutida a presença do ar- quiteto na produção industrial desde componentes construtivos do edifício até os objetos cotidianos de seu interior.

Arquitetura de interiores. O Dirigente Construtor. São Paulo, v. 2, n. 7, p. 33-59, mai. 1966. Caderno Especial.

\section{ODirigente Construtor}

arquitetura de interiores caderno especial (pág. 3з)
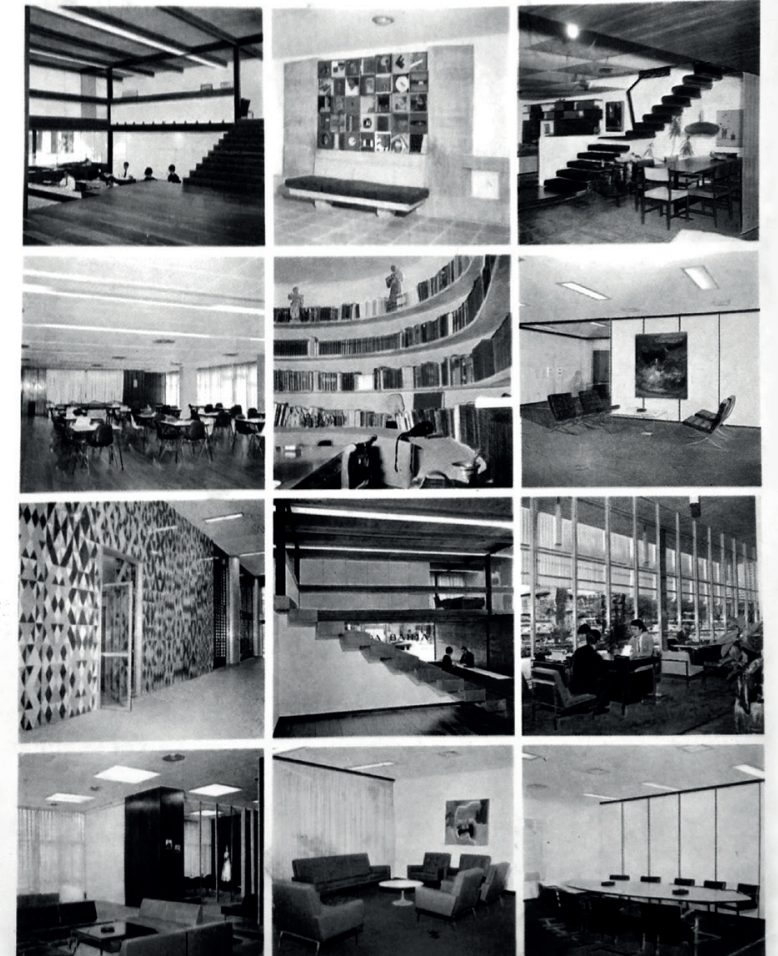

desenho

industrial:

tomada

de consciência
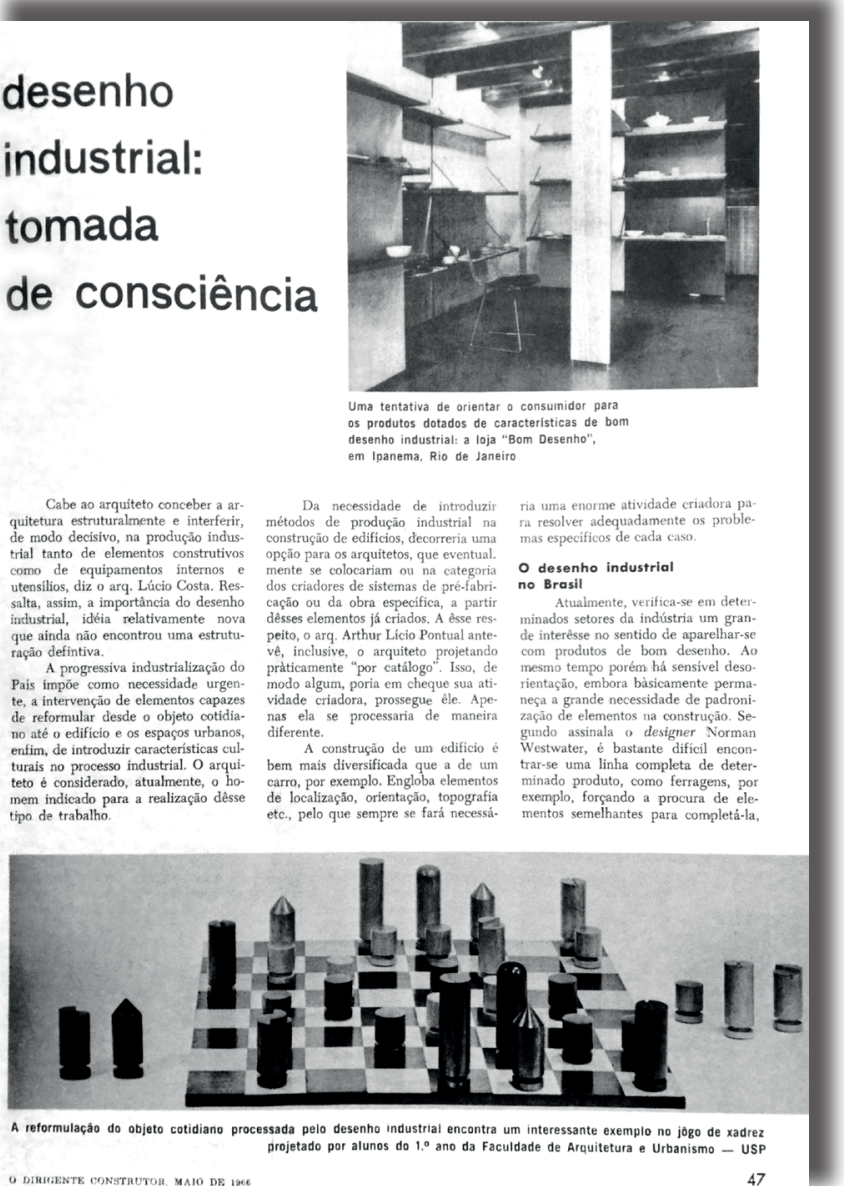
O desenho industrial estaria sendo aplicado ao ensino de projeto de arquitetura? $\mathrm{Ou}$, seria mais uma estratégia de reserva de mercado para os arquitetos? E, afinal, seria necessário que o ensino de arquitetura industrializada fosse desenvolvido propriamente sobre temas de arquitetura para o entendimento das questões de desenho industrial e de produção? E nas disciplinas de projeto de edificações? O que se estudava sobre arquitetura industrializada ou sobre o projeto total - nas disciplinas de projeto de edificação na FAUUSP pós reforma que tinha se empenhado tanto em incluir o desenho industrial em sua grade?

Não muito tempo depois, em 1967, João Batista Vilanova Artigas aceitava o convite ${ }^{5}$ de José Magalhães Prado, superintendente da CECAP - Caixa Estadual de Casas para o Povo, subordinada à Secretaria do Trabalho, Indústria e Comércio do Estado de São Paulo - para elaborar o projeto para um conjunto habitacional em terreno próximo à Base Aérea de São Paulo, em Cumbica, idealizado como o projeto que inauguraria uma nova fase de efetiva atuação da GECAP $^{6}$ — que desde sua fundação em 1949 somente tinha produzido 40 habitações populares para trabalhadores sindicalizados no interior de São $\mathrm{Paulo}^{7}$ — na produção massiva de habitações populares.

Para dividir a direção do projeto, desenvolvido dentro do Escritório Técnico da CECAP, Artigas convidou Fábio Moura Penteado que, por sua vez, convidou Paulo Mendes da Rocha. Outros arquitetos ${ }^{8}$ também compuseram a equipe, como Ruy Gama, Geraldo Vespaziano e Maria Giselda Cardoso Visconti, os primeiros a serem contratados ${ }^{9}$, e Arnaldo Martino, Renato Nunes, Alfredo Paesani e Stipan Dragutin Milic, que completaram a equipe conforme o desenrolar do projeto.

Com uma política de orientar a produção para trabalhadores sindicalizados e a proposta de inaugurar a nova fase já com a construção de um grande conjunto habitacional de 10.000 unidades numa cidade de forte perfil industrial, a CECAP, conforme Buzzar (2014, p. 404), parecia oferecer a Artigas a oportunidade de colocar em prática seu posicionamento político

5 Conforme Dias, 2013, p. 15, o convite teria sido feito por sugestão do arquiteto Ruy Gama, funcionário do Departamento de Obras Públicas e comissionado na CECAP. Ruy Gama graduou-se na FAUUSP em 1953 e portanto era ex-aluno de Artigas.

$6 \quad$ Fatos relatados por Ficher (1972) e Dias (2013).

7 Dias, 2013, p. 15.

$8 \quad$ Ficher, op. cit., c. 1972.

9 DIAS, ap. cit, explica que, conforme a CECAP era um órgão público, os primeiros arquitetos contratados para auxiliar no desenvolvimento do projeto eram já funcionários públicos, no caso Ruy Gama já estava comissionado na GECAP e Geraldo V. Puntoni e Maria Giselda Cardoso Visconti foram trazidos da Diretoria de Obras Públicas. 
sobre desenvolvimento nacional e sobre a atuação "político-profissional" do arquiteto ao elaborar um modelo que contrariasse a lógica de produção habitacional praticada nos últimos anos pelo $\mathrm{BNH}$, de conjuntos habitacionais dormitórios na franja urbana, a maior política "habitacional" implantada até então.

O "laboratório das posições nacionalistas e desenvolvimentistas" (Buzzar, 2014, p. 404) que se tornou o projeto apresentava uma complexidade de arranjos espaciais, apesar da aparente monotonia que a implantação parece sugerir, que tentava recriar uma atmosfera urbana de modo a evitar que o conjunto se transformasse em cidade dormitório. Ainda que projetado para abrigar uma população aproximada de 55.000 pessoas em 180 hectares, o conjunto foi pensado como um local que espraiaria dinâmica urbana para as regiões do entorno, atraindo de $100.000 \mathrm{a}$ 200.000 habitantes das proximidades a usufruir dos setores previstos para comércio local, escritórios e consultórios, além de uma grande área de convivência ajardinada — onde se localizariam uma igreja, um hospital e centro de saúde, um estádio para 15.000 pessoas, teatro, clube e um centro de abastecimento - que interligaria as seis freguesias, onde se localizariam os setores residenciais, que também compreenderiam centros educacionais, perfazendo um total de 192 salas para formação básica e 21 salas para formação profissional, e creches.

Cada freguesia - uma tentativa de evitar estrangeirismos ou traduções impróprias com termos como "superquadra", "neighborhood unit" ou "unidade de vizinhança" — comportava por volta de 32 edifícios de 3 pavimentos acima do piloti, deixando o térreo livre. Cada edifício era formado por duas lâminas de 10 apartamentos contíguos em cada andar e por cinco conjuntos de escadas, que conectavam as lâminas a cada 4 apartamentos em planta, permitindo ventilação cruzada dentro do apartamento e reduzindo as áreas de corredor.

Novamente: apesar da aparente monotonia que a implantação do conjunto parecia sugerir, o arranjo dos apartamentos e dos edifícios proporcionava uma riqueza espacial que tentava reproduzir a atmosfera urbana e incluir a relação da casa com a rua. Miguel Buzzar faz uma leitura bastante interessante sobre a complexidade de espaços projetados, e com a qual concordamos:

\footnotetext{
"A presença da cidade, o pensamento citadino, era novamente trabalhado no projeto. Havia uma hierarquia que auxiliava esse entendimento: o nível coletivo (público) do térreo constituído a partir dos pilotis, os "pátios virtuais" entre as caixas de escadas, a "rua" vertical construída pela caixa de escadas, cujo desenho permitia uma pequena área, uma "saleta", que servia a dois apartamentos, ou seja, um lugar intermediário, entre a circulação "pública" e os espaços privados dos apartamentos, que podia ser "conservado", ou "tratado" pelos moradores". Buzzar (2014, p. 406)
} 


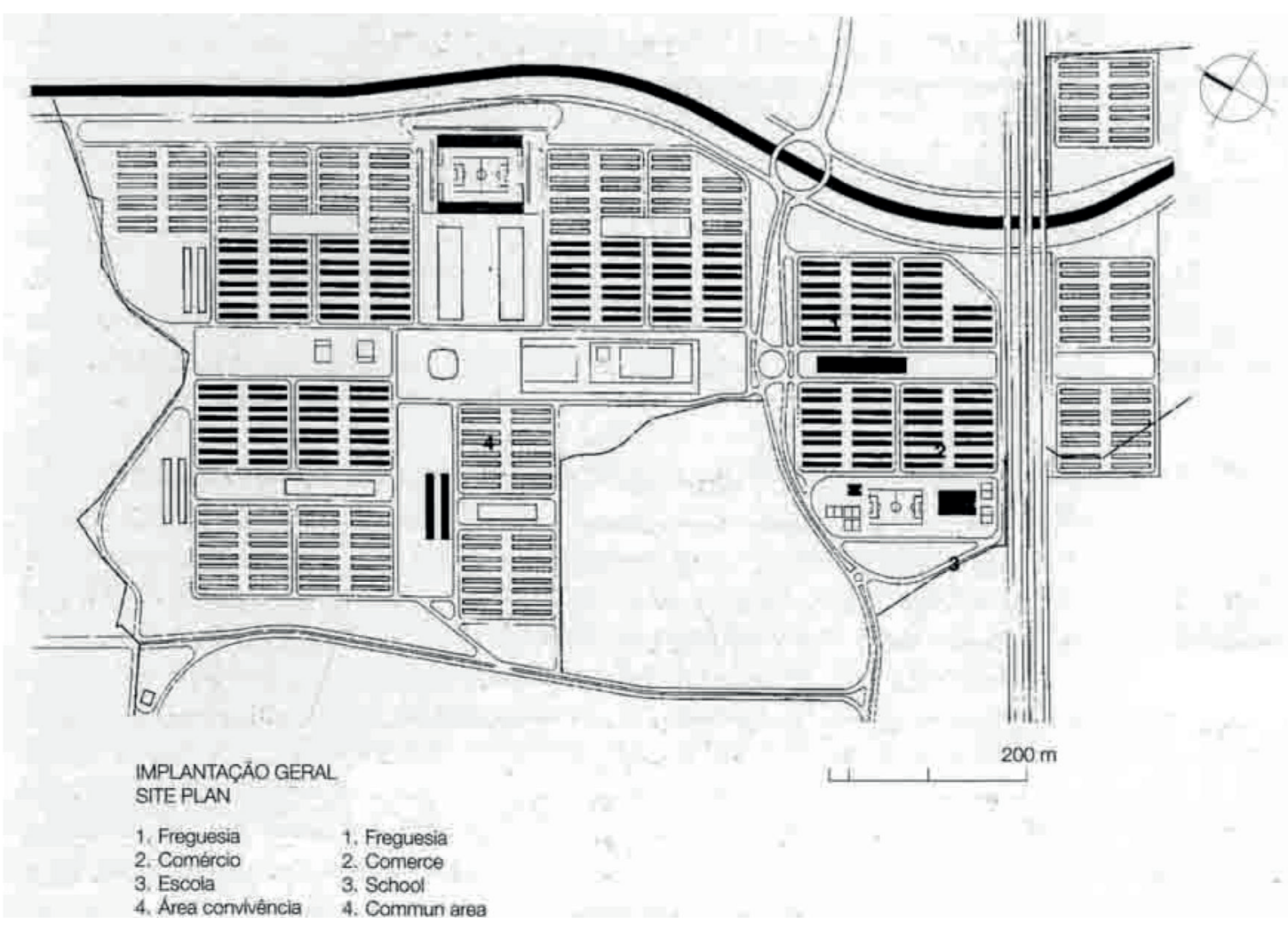

Implantação geral do Conjunto Zezinho Magalhães Prado, próximo à base aérea de Cumbica, Guarulhos. FONTE: Buzzar, 2014. 
Para viabilizar a construção, não só foram feitos exaustivos estudos de otimização da infraestrutura urbana e predial — sistemas de fornecimento de água potável, energia, gás e retirada de esgoto e dos elementos de fundação, demonstrados por Ficher (1972, p. 12-17 e 29-31 ) - como também foi feita a proposta de serem industrializados os sistemas construtivos do conjunto. A viabilidade e barateamento da construção se dariam não só pela industrialização dos sistemas, mas a própria industrialização era viabilizada pelo porte urbano e escala do conjunto. Ainda conforme Buzzar (2014, p. 413), a industrialização da construção e a modernização da produção eram parte do que o conjunto pretendia promover, juntamente com as ideias de convivência urbana: o conjunto deveria funcionar como estímulo da modernização da produção e demonstração do desenvolvimento e do progresso que dependiam da atuação político-profissional do arquiteto. Em uma das pranchas do anteprojeto, um trecho do edifício residencial aparece em perspectiva cônica demonstrando como os sistemas construtivos foram pensados, desmembrados e montados novamente. Eram painéis de laje "pi” (TT) apoiadas sobre vigas-calha, por sua vez apoiadas sobre os pilares do térreo, onde também se encaixavam os pilares do pavimento superior e os painéis que dividiam e separavam os apartamentos, além de possibilitarem a passagem das prumadas de instalação predial; e havia painéis de vedação externa em formato $\mathrm{C}$ onde poderiam ser instalados armários, encimados por janelas que tomavam toda a extensão do apartamento.

Para o habitante, houve ainda a preocupação de viabilizar o apartamento sob os aspectos do tamanho e do layout, do uso e do acesso aos equipamentos domésticos mínimos. Inicialmente, definiu-se o apartamento em planta livre com um núcleo hidráulico de circulação infinita que dividia as funções do banheiro em saleta de banho e um lavabo - permitindo-se a adaptabilidade e divisão do espaço conforme a necessidade dos habitantes. Por algum motivo que não pôde ser averiguado, uma segunda opção de arranjo acabou sendo construída, na qual haveria um só sanitário localizado na lateral do apartamento com cozinha e lavanderia à sua volta. O novo arranjo ainda permitiria que a família definisse o número de dormitórios e o espaço da sala de estar - se dois dormitórios com sala de dupla fachada ou três dormitórios e sala pequena - e mantinha a proposta de instalar armários no perímetro do apartamento, dentro de nichos desenhados nos elementos de vedação, sob as janelas, como forma de aumentar espaço útil interno. E para qualificar o apartamento para além de mero abrigo, tornando-o local de permanência, de satisfação das necessidades básicas e cotidianas - como cozinhar, lavar roupas, assear-se, estudar — foram ainda projetados equipamentos domésticos, que à época já eram indispensáveis à vida moderna, para compor os apartamentos, como fogão, geladeira, forno, máquina de lavar e enxugar roupa, armários e bancadas de trabalho. 


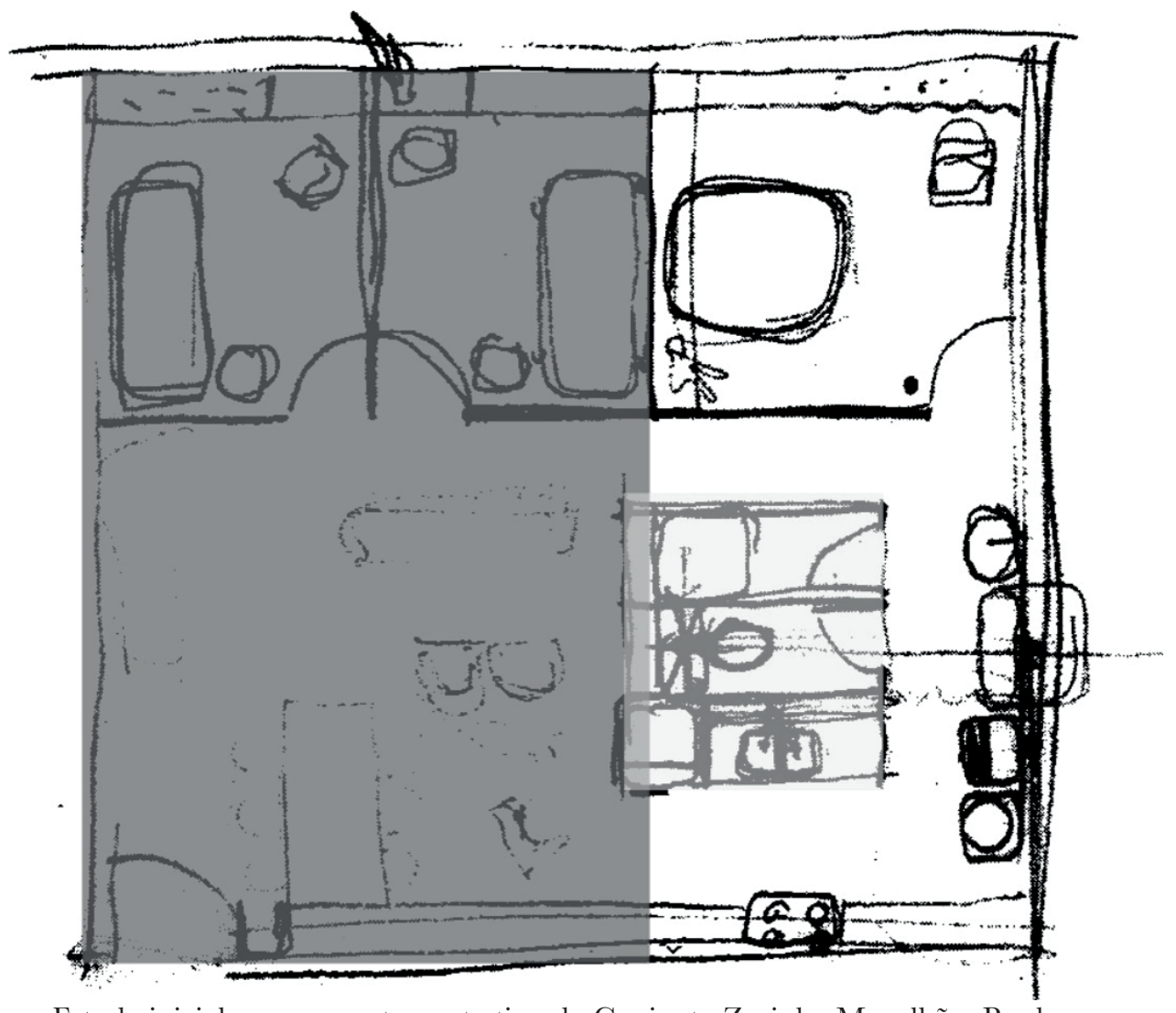

Estudo inicial para o apartamento tipo do Conjunto Zezinho Magalhães Prado FONTE: Revista Contravento n.02 (2004)
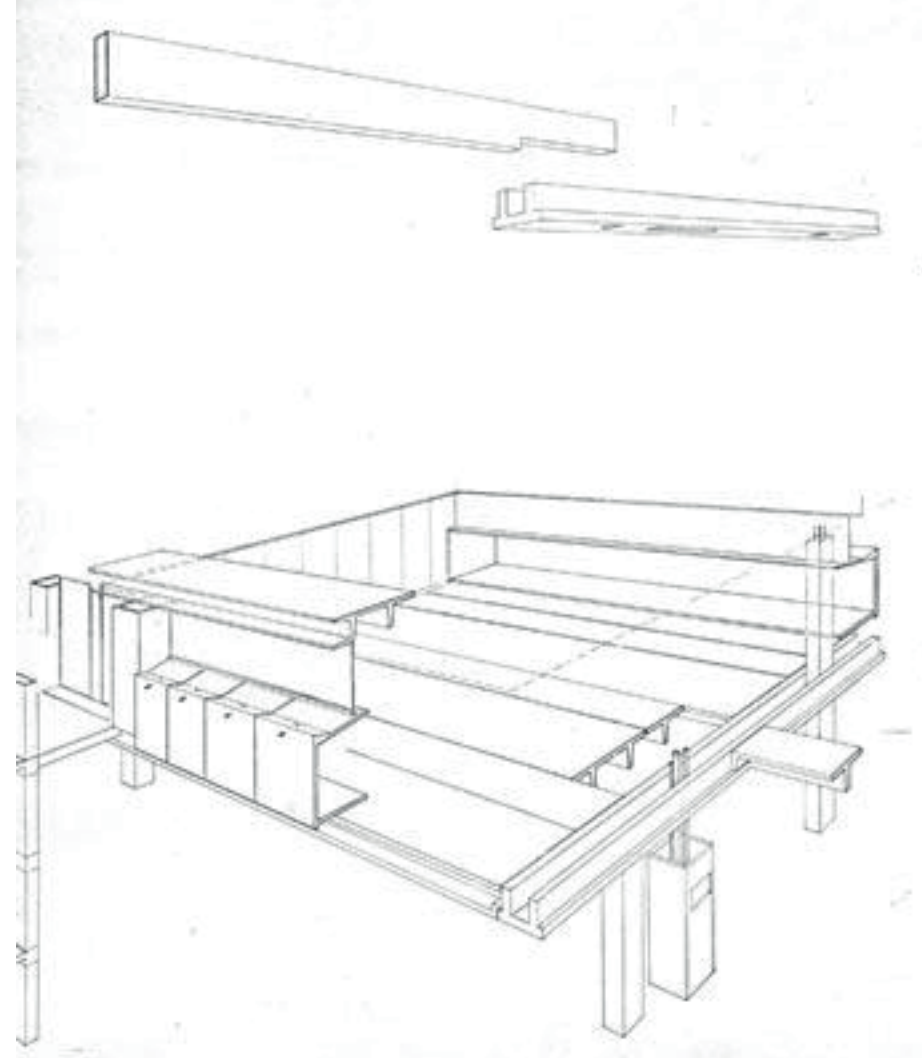

Esquema de montagem dos sistema construtivo do Conjunto Zezinho Magalhães Prado FONTE: Buzzar, 2014. 
Mesmo com o esforço projetual e as felizes perspectivas que se anunciavam, a própria CECAP não possuía recursos suficientes para a construção do conjunto, o que obrigou a equipe a procurar o financiamento da construção junto ao BNH. Conforme Sylvia Ficher, Cr\$15.000.000.000,00 (quinze bilhões de cruzeiros) era o montante estimado em 1968 de investimento necessário para a instalação de uma usina de pré-fabricação para a construção do Conjunto. Para que houvesse retorno do investimento para qualquer empresa envolvida no empreendimento, seria ainda necessária a produção de 5.000 habitações/ano. Além da recusa do BNH em industrializar a construção do conjunto - o argumento de que a industrialização da construção reduz a quantidade de trabalhadores operacionais era e ainda é muito convincente - este teria contratado a execução da obra em etapas e a longo prazo, o que inviabilizou não somente a industrialização das edificações, mas a construção dos equipamentos sociais e das áreas de vivência, comprometendo as ideias de funcionamento do conjunto.

Por um lado, a atitude de projetar os equipamentos domésticos para o conjunto nos faz pensar qual entendimento ou informação a equipe possuía sobre o público-alvo do projeto, os "trabalhadores sindicalizados" de fins dos anos 1960. Ficher (1972, p. 20) aponta que a população em questão estava numa faixa de renda que ou não possuía condições de consumo, ou somente possuía condições de acessar equipamentos de baixo padrão, enquanto Buzzar (2014, p. 411-412) aponta que a ideia era questionar e influenciar o hábito e o gosto de uma população seduzida por produtos industriais kitsch, e um esforço para influenciar o desenvolvimento de uma cultura e identidade próprias. De que maneira esperavam os autores do projeto levar à cabo a produção de eletrodomésticos próprios contra um mercado de bens de consumo que invadiam as casas da população desde o fim dos anos $1950^{10}$ ?

De qualquer modo, o anteprojeto apresentado não só se pretendia como projeto total, mas contemplava muitos componentes referenciais da arquitetura moderna, especialmente remetendo às teorias de Le Corbusier: planta livre com armários embutidos em seu perímetro, edifícios em lâmina com térreo livre com pilotis e organizados em superquadras (freguesia, neste caso), sistemas construtivos fracionados e industrializados (à maneira da casa Domino).

10 Baseamo-nos na argumentação de Mello e Novaes (1998) sobre como o Brasil, desde a década de 1950 até início da década de 1980 (falsamente) se modernizou, especialmente pelo acesso alargado ao consumo, ao mesmo tempo que preservou as antigas diferenças sociais e não permitiu a conquista de direitos históricos. No início do texto, os autores descrevem como o padrão de consumo das classes ricas, médias e pobres mudou ao longo do tempo conforme aumentava a dependência do Brasil por mercados internacionais. 
Tratava-se também de um conjunto habitacional - construído em uma cidade de perfil industrial, que se expandia econômica e populacionalmente - que representava a promessa de organizar o cotidiano urbano dos novos tempos industriais - para Artigas, a representação do potencial da nação brasileira por meio do projeto urbano - de construir uma cidade ideal e harmônica à maneira da Cidade Industrial de Tony Garnier, ou à maneira da Vila Radiosa, de Le Corbusier, de perfeição mecânica, em que cada cidadão cuidaria de seus negócios e afazeres e o meio urbano funcionaria como as engrenagens de uma máquina. O texto de Sylvia Ficher - que à época da elaboração de seu texto, apresentado como Trabalho Interdisciplinar de Graduação em arquitetura na FAUUSP, trabalhava como estagiária da equipe de projetos do Escritório Técnico da CECAP e por isso talvez tenha acompanhado com bastante proximidade as discussões havidas ali - apresenta muito dessas conjecturas que os arquitetos projetaram sobre o comportamento das pessoas no uso do conjunto (o que não é nem foi exclusividade só desse projeto).

Buzzar (2014, p. 406-407) entende que apesar da forte influência de Le Corbusier, o projeto do Conjunto Zezinho Magalhães também parecia informado pela crítica elaborada pelo CIAM do pós-guerra, pela crítica à Carta de Atenas e pelo Team X. De qualquer modo, o projeto não ia "além das propostas que o próprio movimento moderno pregava, ou que seus renovadores buscavam incrementar, com os mesmos objetivos". E apesar de se incomodarem com a assimilação de estrangeirismos, no caso da "freguesia", por acreditarem tanto na necessidade de falar linguagem própria como em relação a preservação e transformação da própria cultura, não se viam incomodados com a importação dos modelos arquitetônicos desenvolvidos no exterior.

E sobre a industrialização, Fábio Penteado - em depoimento a Miguel Buzzar e a Maria Tereza R.L. de Barros Cordido - teria dito que [a ideia de industrialização naquele momento]

"[...] não era importante. O que aconteceu era uma fantasia [...] E arquitetura de pré-fabricação era assim uma ideia. Eu
tinha pouquíssimo contato com o que é pré-fabricação [...] Eu tentei na CECAP, da mesma forma a padronização, por
exemplo, materiais de construção, equipamentos, eu me lembro de uma preocupação com o mobiliário. Um apartamento de
cinquenta e sete, não me lembro, quarenta metros, usar aqueles móveis, mobília de São Bernardo. Não só com os
mobiliários, mas com quase todos os equipamentos, eu buscava formar uma pesquisa para o futuro da industrialização quando ela chegasse ao Brasil." (Buzzar, 2014, p. 414).

Para além das condições de se poder industrializar a arquitetura de edifícios à época ou não, o que significava esse "quando a industrialização chegar ao Brasill"? Até onde iria o alcance da atuação político-profissional do arquiteto na modernização da produção ou na provisão de habitação? 
Paralelamente às tratativas com a CECAP, em 1969, o mesmo BNH firmava contrato com o Centro Brasileiro da Construção - Bouwcentrum para a elaboração de um "Plano de Implantação da Coordenação Modular”, com a intenção de avaliar as possibilidades de industrializar a construção civil no Brasil.

Esse episódio — veiculado oficialmente pelo "Noticiário da Coordenação Modular" produzido pelo Departamento Técnico do Centro Brasileiro da Construção - Bouwcentrum, São Paulo, e por revistas como Acrópole ${ }^{12}$ e o Dirigente Construtor ${ }^{13}$ — é contado pelo prof. Paulo Bruna ${ }^{14}$ que pôde acompanhar a finalização da tal pesquisa realizada pelo engenheiro Teodoro Rosso (junto a outros profissionais), um entusiasta da industrialização da arquitetura que colocou praticamente todos os seus trabalhos e pesquisas em função desse tema ${ }^{15}$.

Teodoro Rosso preparara então um extenso trabalho, com quase 800 páginas, que abrangia tópicos sobre análise de componentes modulares, desde paredes internas e externas, passando por coberturas, acabamentos até caixilhos de portas e janelas; juntas para componentes; controle de qualidade e tolerâncias; serviços para documentação, divulgação e informação; séries numéricas para a coordenação modular e projetos didáticos, provavelmente para o ensino da Coordenação Modular.

Pelos relatos ${ }^{16}$, o trabalho foi mal aceito e a coordenação modular nunca implantada, ao menos pelo $\mathrm{BNH}^{17}$. Nestor Reis, na entrevista que nos concedeu, comenta sobre como era (e ainda é) comum que órgãos públicos no Brasil fiquem à mercê das vontades de seus dirigentes, não havendo muitas vezes uma diretriz ou uma política estatal forte que caracterize os propósitos de tal órgão e, então, nos deparamos com um BNH que ora recusa projetos 11 Noticiário da Coordenação Modular. São Paulo, CBC-Bouwcentrum, ago de 1970, número 9.

12 CBC faz estudos para o BNH. Acrópole. São Paulo, n. 366, p. 11, out. 1969.

13 Um ano e meio de atividades no Centro Brasileiro da Construção. O Dirigente Construtor. São Paulo, v. 6, n. 07, p. 126, mai. 1970. Entrevista

14 Episódio contado tanto informalmente, durante suas aulas na pós-graduação da FAUUSP como em entrevista realizada em 06 de março de 2015

15 Rosso, Teodoro. Proposta o servico de teto e metodos artesanais e metodos industriais. São Paulo, FAU, 19-?.

1966. Pré-fabricação, a coordenacao modular teoria e pratica. São Paulo, Instituto de Engenharia, Teoria e pratica da coordenacao modular. São Paulo, FAU, 1976. . Racionalizacao da construção. São Paulo, FAU/USP, 1980. 300 p.

16 Pelos depoimentos de Paulo Bruna ou Nestor Reis e pelo Trabalho de Graduação Interdisciplinar de Antônio Carlos Sant'Anna (1974).

17 O próprio produto da pesquisa, o relatório entregue ao $\mathrm{BNH}$, não pode ser localizado. 
industrializados ora contrata pesquisas para industrializar a produção de habitação.

Ao longo da elaboração da pesquisa, conforme relato de Paulo Bruna, Teodoro Rosso já circulava pela FAUUSP, mas só em 1973 Teodoro seria contratado como docente do Departamento de Tecnologia da Arquitetura pelo então diretor da escola, Nestor Goulart Reis Filho ${ }^{18}$.

Esses três episódios talvez resumam bem como o tema da industrialização da arquitetura permeava os debates entre os arquitetos e outros personagens, durante os anos 1950 e 1960, sobre muitos assuntos (já que o tema da industrialização dificilmente aparece isolado) entre os quais os rumos profissionais dos arquitetos, o desempenho de uma função social definida na produção industrial, o ensino de projeto que abordasse as necessidades dos tempos atuais (de então) e, especialmente, a defesa de um certo papel político-profissional do arquiteto na produção de habitação e no desenvolvimento urbano.

Ao mesmo tempo, os episódios apontam algumas das instituições em que aconteciam ou que promoviam esses debates: as entidades de classe (categoria), com a ABDI, instituições governamentais como o BNH e órgãos associados (como o Bouwcentrum) e as revistas especializadas da época, também permeadas por anúncios de produtos industrializados para a construção civil, já largamente utilizados. E os textos apresentavam termos que não eram "naturais" do meio, mas tinham sido incorporados, por toda a sociedade ao longo do século XX, como "organização", "função" e, especialmente, "planejamento".

Outro fato ainda unia nossos personagens: eram eles docentes, ex-alunos e futuros docentes da FAU e se encontravam no centro de um debate sobre industrialização da arquitetura e da habitação popular, promovido especialmente pelo BNH durante os anos 1960.

Mas a fundação da FAU estava ligada a um debate sobre autonomia da profissão do arquiteto (em relação à formação politécnica) e ao estabelecimento de um campo de atuação do arquiteto no urbanismo que ainda não tinha reconhecido a possibilidade do arquiteto atuar também junto à produção industrial. Como contra exemplo citamos a Bauhaus, uma escola criada por arquitetos crentes nas teorias da Administração Científica, entre os quais Walter Gropius, que "desejava formular uma nova teoria sobre arquitetura e desenvolver um design útil para os bens de consumo da atualidade que pudessem ser produzidos em massa", conforme discute Guillén (2009, p. 10, tradução nossa). Gropius, seus colegas, discípulos e alunos, ainda conforme Guillén, 
colaboraram durante muito tempo com muitas indústrias alemãs no design de bens de consumo, além de terem proposto um novo método para treinar arquitetos que enfatizava o método e a utilidade. O ensino na FAUUSP demoraria para aplicar questões de método e utilidade, e praticamente não se relacionou com as empresas brasileiras.

Se o tema da industrialização da arquitetura não estava na origem da FAUUSP, como aparece entre seus docentes ou profissionais a ela ligados? Por comparação às disciplinas de Desenho Industrial - que não trabalham desenho de componentes, mas bens de consumo em geral, animados pelo período desenvolvimentista por que passa o Brasil no final dos anos 1950 durante o governo de Juscelino - o tema era trabalhado nas disciplinas de projeto de arquitetura ou já estava presente no amadurecimento do curso ao longo dos anos 1950? E mais, como a industrialização e o desenvolvimento da sociedade em geral passam a ser preocupação dos arquitetos? 


\section{As ideias de industrialização nos Congressos de Arquitetos}

O tema da industrialização aparecia também nos Congressos, quando os arquitetos trocariam informações ou tomariam contato com referências daquilo que se discutia ou produzia fora dos pequenos círculos sociais em que estavam inseridos.

Os arquitetos e outros profissionais do setor também se reuniriam em outras ocasiões, como na Jornada Nacional de Habitação (São Paulo, julho de 1962), na Mesa Redonda Pan Americana de Arquitetos (São Paulo, novembro de 1962), Seminário de Habitação e Reforma Urbana (Rio de Janeiro e São Paulo, julho de 1963) e na Mesa Redonda sobre Política Habitacional (Rio de Janeiro, julho de 1966). Mas para esta dissertação, escolhemos apontar somente algumas discussões ocorridas nos Congressos Brasileiros de Arquitetos e nos Congressos da União Internacional de Arquitetos.

\section{Os Congressos Brasileiros de Arquitetos}

O $1^{\circ}$ Congresso Brasileiro de Arquitetos, ocorrido em janeiro de 1945, em São Paulo, foi especialmente importante para a consolidação da ideia das escolas autônomas de arquitetura, discutido no âmbito do tema 2 do congresso, "assuntos de interesse imediato da profissão". No âmbito do tema 1, "função social do arquiteto", uma das discussões girou em torno do "equipamento industrial como base para a evolução arquitetônica" e a "necessidade de um maior entendimento entre o arquiteto e a indústria".

Em Porto Alegre, no $2^{\circ}$ Congresso Brasileiro de Arquitetos, de 1948, o tema 3, "A arquitetura e Indústria" retomou o debate da "indústria na evolução da arquitetura", mas também tocou em assuntos sobre "a indústria nacional de materiais de construção" e a "modulação da construção - padronização". Não muito tempo depois, em 1950, seria publicada a primeira norma de coordenação modular brasileira, a NB-25R.

No $3^{\circ}$ Congresso Nacional de Arquitetos ${ }^{19}$, julho de 1953, em Belo Horizonte, novamente abordou o tema da "racionalização e normalização". A tese n ${ }^{\circ}$ 8, "Prática Profissional racionalização e normalização", apresentada por Rino Levi e Rubens Gouvêa Carneiro Viana propôs que o III CNA recomendasse aos poderes públicos a revisão de seus Códigos de Obras com a participação das entidades de classe interessadas. Não tratou, portanto, do que talvez o título "racionalização e normalização" sugere.

19 Este foi chamado de Congresso Nacional, e não Congresso Brasileiro. 
A tese $n^{\circ}$ 9, sobre "Prática Profissional - experiência e pesquisa", no entanto, apresentada pela própria $3^{\text {a }}$ Sub-Comissão de estudos do Grupo III propôs que o $3^{\circ}$ CNA recomendasse ao IAB que por sua vez promovesse e incentivasse "pesquisas e experiências sobre os processos adotados na edificação e sobre os materiais de construção, tendo em mira os interesses e a colaboração do arquiteto, do especialista e do industrial'. A tese apresentada em 1953 apontava para uma necessidade que só em fins da década de 1960 seria enfrentada. A tese considerava que os materiais e processos construtivos obedeciam ainda normas empíricas, sem padronização (o que traria vantagens econômicas ao projeto) e que ainda não estavam disponíveis informações científicas sobre os insumos para a concepção do projeto e execução da obra.

Mas o $4^{\circ}$ e o $6^{\circ}$ CBA talvez tenham sido os mais interessantes para o nosso trabalho.

O $4^{\circ}$ Congresso Brasileiro de Arquitetos, ocorrido em 1954, contaria com a presença ilustre de Walter Gropius ${ }^{20}$ que discursaria para os arquitetos brasileiros — na plateia vários arquitetos que já eram docentes da FAUUSP ou o seriam em breve ${ }^{21}$, além da presença de representantes do Gfau - a conferência intitulada de "O Arquiteto na Sociedade Industrial”, em que tratou dos mesmos temas que os arquitetos de sua geração já tratavam desde as primeiras décadas do século XX, tais como a necessidade do arquiteto integrar a equipe do engenheiro e do industrial, mas provando seu valor como o "mestre da indústria da construção", ou sobre as "possibilidades milagrosas da máquina". Em sua fala, tentava ilustrar que o ápice dessa situação ocorreria com os arquitetos consultando catálogos de produtos industrializados, produtos esses que deveriam ser projetados pelos mesmos arquitetos e lamentava que, à época, somente os engenheiros e os homens de ciência fossem responsáveis por produzi-los.

Além da conferência de Walter Gropius tratando do papel do arquiteto na produção industrial, "Arquitetura e indústria" era uma dos temas que retornava a esse Congresso, mas curiosamente não houve propostas para serem debatidas. A própria comissão ${ }^{22}$ organizadora

20 Alvar Aalto, presente no Congresso, não mereceu o mesmo destaque que Gropius nas revistas. FONTE: IV Congresso Brasileiro de Arquitetos. Acrópole. São Paulo, n. 185, set. 1954. Boletim Mensal do IAB.

21 Tais como Eduardo Corona, Abelardo de Souza, Ariosto Mila, José Vicente Vicari, Ícaro de Castro Melo, Oswaldo Corrêa Gonçalves, Lauro Bastos Birkholz, Rino Levi, Eduardo Kneese de Melo e Zenon Lotufo entre os docentes. E Frejda Blinder, Ruy Gama e Roger Zmékhol entre os arquitetos recém-formados na FAUUSP, conforme descrito nos Anais do IV Congresso Brasileiro de Arquitetos, realizado em São Paulo em 1954.

22 A Comissão n.2, "Arquitetura e Indústria", além do Gfau, era formada pelos arquitetos Jorge Mendes de Oliveira Castro, Valentim Peres de Oliveira Neto, Jacqueline Bermann, Egon Weindorfer, Luiz Miguel Moréa, Raul Oscar Grego, Edyrceu Fontoura, Mário José Corrêa, Ary Garcia Roza, José Bina Fonyat Filho, Salomão Tandeta, Maurício Dias da Silva, Hélio Moreira, Paulo Ricardo de Aratanha, Victor Noel Saldanha Marinho, Edson Lima, Antônio Albuquerque, Horácio Mingone Aguiar, Francisco de Paula Dias de Andrade, João Augusto Calmont, Oswaldo Nery e Hector Frederico Has, que para este trabalho não têm relevância. 
do tema foi então responsável pelo texto apresentado nas conclusões do congresso, para evitar constrangimento. Em seu texto, a comissão considerou especialmente muitas das ideias trazidas por Gropius mas também examinou de modo geral os problemas relativos ao tema, observando que justamente na produção industrial (de materiais, produtos e equipamentos da construção) havia uma tendência de menor participação do arquiteto em relação a outros setores de trabalho, como o projeto, o planejamento, a direção do canteiro de obras. Consideraram então alguns dados para a análise, que:

a) a produção de materiais de construção era feita a partir dos interesses dos grupos comerciais e empresariais, e não com os objetivos da criação;

b) os esforços de padronização, estandardização e racionalização dos produtos industrializados são inúteis sem a participação dos arquitetos;

c) o desenvolvimento tecnológico da indústria da construção não está em consonância com os outros setores industriais, daí que a primeira não está sendo usada para propiciar melhores condições de vida ao homem;

d) as condições de vida dos extratos mais pobres da população não são conhecidas;

e) o desenvolvimento do conhecimento deve ser feito por meio de pesquisas executadas em canteiros experimentais;

f) é imprescindível a formação de uma consciência de trabalho em equipe para a produção arquitetônica; e

g) não são facultados nos bancos escolares os conhecimentos suficientes sobre materiais, produtos e sistemas a respeito da sua relação com a composição arquitetônica.

Depois dessas considerações, a comissão elaborou 2 recomendações que nos interessam particularmente: a primeira, que o IAB promovesse as articulações necessárias entre os vários atores $^{23}$ do meio para que fossem criados organismos de orientação material e intelectual na realização do projeto e da obra e organismos de pesquisa que considerassem os estudos dos processos de construção, equipamentos e instalações, higiene da vida do homem na habitação. A segunda recomendação consistiu em solicitar que a comissão "Ensino da Arquitetura" do $4^{\circ}$ Congresso destacasse não somente a importância das disciplinas escolares sobre os materiais de construção, métodos, técnicas construtivas e higiene das habitações e a apropriação desses

23 Entre arquitetos, entidades representativas das indústrias relacionadas à construção civil, industriais, projetistas, estabelecimentos de ensino de arquitetura e engenharia e entidades interessadas no problema da habitação, racionalização e normalização. 
conhecimentos na obra arquitetônica, mas também destacasse a necessidade de criação de cursos técnicos de desenho industrial aplicado à arquitetura.

Talvez por coincidência Ariosto Mila tinha então apresentado a tese "A Cadeira de Construções Civis no ensino de Arquitetura" sobre a Cadeira de Construções Civis ser das mais importantes no curso pois é onde o aluno realiza a concatenação dos elementos estudados em Resistência dos Materiais, Materiais de Construção, Hidráulica, Concreto, Mecânica dos Solos, Composição Arquitetônica, Desenho, Topografia. Depois de descrever sua cadeira, organizada através de aulas expositivas e execução de alguns processos construtivos pelos estudantes, Ariosto propunha que fossem criados escritórios piloto/didáticos para vivência dos alunos da prática profissional.

Apesar de se aproximar parcialmente do que a Comissão "Arquitetura e Indústria" recomendava, Ariosto à época já enxergava a construção civil, e também a pré-fabricação de componentes, como um repertório de sistemas construtivos fracionados - e não como questão de projeto. Essa visão da obra fracionada, algum tempo depois, basearia a tese que apresentou à FAUUSP para se tornar catedrático da cadeira "Construções Civis".

O $6^{\circ}$ Congresso Brasileiro de Arquitetos ${ }^{24}$, ocorrido em Salvador, em 1966, teve como tema principal "A Arquitetura e o meio ambiente", com o qual os arquitetos se preparariam para o IX Congresso da UIA a ocorrer em Praga, República Tcheca (Tchecoslováquia à época, URSS), em julho de 1967, cujo tema seria o mesmo.

O questionário enviado às nações que participariam do IX Congresso da UIA em Praga contido no material impresso do $6^{\circ} \mathrm{CBA}$ - continha uma das questões mais importantes à época, que dizia respeito à construção e reconstrução não só do território soviético, mas de todos os países que já tinham iniciado o enfrentamento do déficit habitacional: “(...) Como resolver a contradição entre a obsolescência dos edificios e as novas necessidades do homem e da sociedades?". Essas questões permeavam um momento em que as necessidades por habitação não tinham ainda sido satisfeitas, ao mesmo tempo em que as construções implantadas no pós-guerra já entravam em declínio e obsolescência. Novamente, o tema da industrialização da arquitetura voltava à pauta dos CBAs.

Mas, apesar de (1) Breno Cirino Nogueira, em sua tese ${ }^{25}$, ter discutido que o desenvolvimento

$24 \mathrm{O} 5^{\circ}$ Congresso, cuja programação foi descrita em artigo da revista Acrópole não é relevante para nosso trabalho. Também não localizamos os Anais do Congresso para análise. FONTE: $5^{\circ}$ Congresso Brasileiro de Arquitetos - Regulamento. Habitat. São Paulo, n. 42, p. 59, jun. 1957

25 Talvez a única contribuição ao debate do TEMA 4: "a indústria e o ambiente de trabalho". FONTE: NOGUEIRA, Breno Cirino. Contribuição à tese do departamento de São Paulo ao IV CBA - TEMA 4: a 
industrial brasileiro necessitava que a pré-fabricação de edificios industriais em grande escala recebesse atenção dos arquitetos; e (2) da Equipe de Planejamento Integrado da Faculdade de Arquitetura da $\mathrm{UFBA}^{26}$ ter proposto para o $7^{\circ}$ Grupo de Trabalho, sobre "Revisão e Atualização do Ensino", que as cadeiras técnicas - tendo como eixo a composição (ou o projeto) - deveriam possibilitar aos alunos a criação de elementos pré-fabricados para a industrialização da construção, e que esta industrialização fosse entendida como a aplicação de elementos pré-fabricados à composição arquitetônica, permitindo aliar qualidade à quantidade; o relatório final do $6^{\circ}$ Congresso, cujo relator era João Batista Vilanova Artigas, iria recomendar a não pré-fabricação.

Escrito pelo Grupo $3^{27}$ e consolidado pelo Relator Geral do Congresso, o arquiteto João Batista Vilanova Artigas no Relatório Final recomendou que

"A adoção dos processos de pré-fabricação não podem ser considerados como capazes de se constituírem em métodos realmente eficazes e adequados à solução da crise habitacional brasileira. Neste particular, recomenda-se antes a prática dos métodos que tendem a racionalização do processo construtivo e um maior cuidado na fase de projeto e do planejamento. Os modernos métodos construtivos - a préfabricação entre eles - devem, todavia, ser tentados, experimentados e testados em escala apropriada, pois se constituem em fatores primordiais do aperfeiçoamento da indústria da construção brasileira". ${ }^{28}$

Com a leitura desse trecho, é possível perceber que os arquitetos talvez não fizessem ideia do significado de racionalização do processo construtivo ou do que pudesse significar racionalização na fase de projeto e planejamento, uma vez que racionalizar é a própria etapa de projeto e planejamento.

No mesmo texto ainda podemos encontrá-los sugerindo a mobilização dos recursos públicos para a autoconstrução (materiais de construção e assistência técnica) em situações em que nenhuma outra solução fosse possível, quando então se deveriam garantir o mínimo de

industria e o ambiente de trabalho - algumas características fundamentais da industrialização no Brasil. In Congresso Brasileiro de Arquitetos. 6º 1966. Anais. Salvador: IAB, 1966.

26 Equipe formada por Sérgio Soares Dias, Margarida Motta, João C. Brasileiro e Marçal Fonseca.

27 Conforme o regulamento impresso, a composição do Comitê de Conclusões era a seguinte: Arq. Benito Sarno (Presidente do VI CBA); Arq. Flávio Léo Azeredo da Silveira (VP da UIA); Arq. Fábio Penteado (Presidente do IAB); Arq. Carlos Maximiliano Fayet (VP Coordenador das Divisões Nacionais de Trabalho); Arq. J.B. Vilanova Artigas (Relator Geral do VI CBA); Arq. Sabino Barroso (Secretário Geral do IAB); Arq. Acácio Gil Borsoi; Arq. GianCarlo Gasperini; Arq. Joaquim Guedes Sobrinho; Arq. João Ricardo Serran; Arq. Jorge Wilheim; Arq. Maurício Roberto; Arq. Wladimir Alves de Souza; Arq. Ary Penna Costa (Sub-diretor da DINCAI); Arq. Alberto Xavier (sub-diretor da DINCED). O Grupo de trabalho 3, Ambiente Habitável ou Ambiente Residencial, possuía como Presidente o Arq. Ícaro de Castro Melo, como relator o Arq. Joaquim Guedes Sobrinho e como secretário coordenador o Arq. Maurício Nogueira Batista. FONTE: CONGRESSO BRASILEIRO DE ARQUITETOS, 6. 1966. Anais. Salvador: IAB, 1966.

28 Relatório Final. CONGRESSO BRASILEIRO DE ARQUITETOS, 6. 1966. Anais. Salvador: IAB, 1966. 
infraestrutura (água, esgoto, energia elétrica, equipamento social básico - escola e posto). Isso resume a nossa periferia. O mais interessante de tudo, por fim, é que os arquitetos ainda se consideravam indispensáveis para o desenvolvimento industrial do país, mesmo recomendando a não pré-fabricação e a autoconstrução, assim:

"Considera-se, finalmente, a presença do Arquiteto brasileiro no processo de industrialização do país, criando melhores ambientes de trabalho o que permite afirmar que sua atuação é indispensável, desde os primeiros momentos do planejamento industrial nas equipes polivalentes que buscam objetivar o diálogo entre os profissionais e a própria solução final’"29. (Relatório Final. CONGRESSO BRASILEIRO DE ARQUITETOS, 6. 1966. Anais. Salvador: IAB, 1966.)

\section{Os Congressos da União Internacional de Arquitetos}

Apesar da UIA ter sido criada em 1948, depois que os arquitetos no Brasil começaram a se reunir - o $1^{\circ}$ Congresso Brasileiro de Arquitetos ocorreu em 1945 - muito do que se debatia nos congressos internacionais repercutia entre os arquitetos brasileiros: ou antes, quando os congressos nacionais seriam utilizados como espaço preparatório para a reunião internacional, ou depois, nas revistas, em que se reportavam as conclusões dos congressos.

A julgar pelo material localizado nas revistas de arquitetura, o primeiro congresso em que participaram os arquitetos brasileiros ${ }^{30}$ foi em Lisboa ${ }^{31}$, em abril de 1953, sob o tema da "A Arquitetura na Encruzilhada", em que se debateu "a formação do arquiteto", "a posição social do arquiteto", "relações entre arquitetos e engenheiros", "a síntese das artes plásticas", "urbanismo", "habitat", "construções escolares" e "industrialização". Sobre a industrialização havia um tom de entusiasmo com os resultados (talvez por conta da quantidade e da velocidade de produção) que se percebia na reconstrução das cidades e o Congresso enfatizava a necessidade de integrar o trabalho do arquiteto ao trabalho do industrial (produtor de componentes) e ao do construtor, pois a construção civil parecia o único setor industrial em que essas entidades ainda não trabalhavam de forma homogênea. O Congresso então faria uma recomendação à ISO (International Organization for Standardization) para que se adotasse o módulo construtivo de $10 \mathrm{~cm}$ numa base mundial, uma vez que muitos países, e

29 Relatório Final. CONGRESSO BRASILEIRO DE ARQUITETOS, 6. 1966. Anais. Salvador: IAB, 1966.

30 Possivelmente os arquitetos de São Paulo, já que foi na revista Acrópole onde se relatou tal reunião.

31 União Internacional de Arquitetos - Conclusões do Congresso de Lisboa, 1953. Acrópole. São Paulo, n. 185, set. 1953. Boletim Mensal do IAB.

Conclusões do Congresso de Lisboa - 1953 (continuação). Acrópole. São Paulo, n. 185-186, set./out. 1953. Boletim Mensal do IAB. 
muitos arquitetos, já o adotavam.

O outro congresso que tratou diretamente da industrialização da arquitetura ocorreu em Moscou, sob o sugestivo tema da "Construção e Reconstrução das Cidades, 1945 -1957". Durante o congresso, vários arquitetos brasileiros tiveram oportunidade de verificar pessoalmente o que se produzia de habitação na União Soviética. Pelos relatos, viram e não gostaram. Os arquitetos Maurício Roberto e F.A. Regis, que lá estiveram, reprovaram o resultado da arquitetura soviética do período estalinista, pois, como comenta F.A.Regis, "dispondo os soviéticos de uma indústria poderosa, a ponto de estarem realizando em massa o que até agora, noutros países, tem sido apenas ensaio - isto é, o prédio pré-fabricado - é de admirar que estejam, ainda, apegados às formas e estilos do passado, num academicismo já ultrapassado mesmo em países de organização social e técnica mais atrasadas" ${ }^{\prime 2}$, fazendo referência ao ecletismo historicista da arquitetura estalinista que, no entanto, era produzida em escala com o emprego do aço - matéria-prima consolidada na indústria de base do período estalinista - nas estruturas e alvenaria de tijolos nas vedações.

Desde 1954, com a morte de Stalin, que a produção de edifícios passou então a ser baseada na indústria do cimento. Correspondendo ao período de Nikita Krushev (1954-1964), porém, é que a construção civil na união soviética atinge seu mais alto grau de industrialização. Em 1958, 70\% dos componentes construtivos na URSS era pré-fabricada, em oposição aos 25\% de 1950 (Ockman, 1993, p. 185-188). Vale lembrar que, em 1954, o recém-empossado Secretário Geral do Partido Comunista da União Soviética, Krushev proferia o discurso "Retirem despesas no projeto, otimizem os trabalhos dos arquitetos" (KRUSHEV citado por OCKMAN, 1993, p.185-188) dirigido aos arquitetos soviéticos e pretendia antes de tudo desconstruir o legado stalinista, principal marca de seu governo, em todos os aspectos da cultura do país, arquitetura incluída, tentando firmar-se como um possível novo estadista a ficar para a história por ter iniciado uma nova era no desenvolvimento soviético. Apesar de vencido por outro grupo dentro do partido, seu discurso ficou para a história materializado, junto com a arquitetura historicista monumental do realismo estalinista, sob a forma de uma arquitetura sem graça de grandes elementos pré-fabricados em vastas e estéreis paisagens repetitivas.

Ao longo dos anos 1950 e 1960, todos os congressos debateriam temas da arquitetura moderna que também ecoavam no Brasil ${ }^{33}$. Mas deve ter sido o $7^{\circ}$ Congresso, em Havana,

32 Depoimento e peripécias em torno da arquitetura soviética. Habitat. São Paulo, n. 26, p, 45-46, jan. 1956. Seção Noticiário.

33 A lista completa dos Congressos de Arquitetos da União Internacional dos Arquitetos pode ser 
que mais marcou os arquitetos que lá estiveram. Neste, vários países desenvolvidos, como Inglaterra, Dinamarca e França levariam imagens e desenhos da sua produção de habitação mais recente, industrializados com grandes painéis de concreto, para contribuir com o debate. União Soviética e Cuba, que exporia ao vivo sua produção, davam mostra da eficiente máquina soviética de fazer casas, já que o Congresso era uma oportunidade de mostrar ao mundo os recentes resultados da revolução.

No Congresso de Havana, não somente o que os países demonstravam impressionou os brasileiros. Ocorrido em setembro de 1963, às vésperas do golpe militar de 1964, muitos arquitetos que retornaram da viagem foram ameaçados, ou até presos e torturados, conforme relato de César Dorfman (2013). Comentaremos mais sobre Cuba no capítulo 3.

E, apesar de terem se preparado para o IX Congresso da UIA, que ocorreria em Praga, durante o $6^{\circ}$ Congresso Brasileiro de Arquitetos, 1966, em Salvador, não houve delegação brasileira no encontro, conforme os anais do mesmo Congresso da UIA, em Praga. Possivelmente, uma "inoportuna" viagem a Cuba para o $7^{\circ}$ Congresso da UIA, às vésperas do golpe militar de 1964, fez muitos arquitetos reconsiderar a necessidade de participar de um congresso que aconteceria novamente num país aliado da União Soviética.

verificada aqui: http://www.uia.archi/en/s-informer/congres/tous-les-congres\#.VsoET4SMOkg, consultada em 10 de dezembro de 2015. 


\section{O legado da revolução mental de Taylor na arquitetura}

No âmbito internacional, o discurso de vários arquitetos canônicos do movimento moderno refletia a adoção das teorias da administração científica.

Em várias oportunidades, Walter Gropius (GROPIUS, 1910, 1927), que apresentou muito desse pensamento aos arquitetos brasileiros durante o $4^{\circ} \mathrm{CBA}$, demonstraria não somente sua fé na industrialização e na máquina, pela promessa de se produzir habitações e bens de consumo em massa, mas também repetiria que era o arquiteto o profissional capaz de orientar as qualidades técnicas e artísticas da produção, unindo-as às qualidades econômicas da industrialização.

Ou Ernest May (MAY, 1929) que acreditava que a casa deveria ser o produto tecnológico do trabalho de muitos profissionais especializados: engenheiros, físicos, higienistas, capazes de considerar as necessidades humanas, sejam biológicas sejam sociais. Ernest May também considerava a organização da habitação mais importante que a composição de fachadas. Essa fala já refletia a transição da prática beaux-arts de composição de fachadas para a prática moderna de composição de plantas, quando os princípios de funcionalidade e organização entre os ambientes passavam a ser mais importantes que uma fachada decorada.

Essas falas refletiam os aspectos que passavam a ser considerados na arquitetura moderna e que dialogavam com a "revolução mental" que foi a administração científica: quando transformavam a vida em dados técnicos (as "necessidades" fisiológicas que se tornavam funções e dados para o projeto da habitação), mecanizando a vida humana; quando dividiam as tarefas, obviamente defendendo a atividade de projeto e planejamento (hierarquicamente mais altas) para o arquiteto; ou o fracionamento da produção com a subdivisão de elementos construtivos e as propostas de pré-fabricação de componentes.

Outro texto que mostra como a administração científica se refletia no projeto de arquitetura foi escrito por Le Corbusier e Pierre Jeanneret, em 1929, durante o CIAM de Frankfurt.

"A "padronização" é o meio pelo qual a indústria pode viabilizar a produção de um objeto em série a baixo custo. As funções domésticas da casa têm um caráter incontestável: se realizam sobre planos horizontais que são os pisos; necessitam de fonte luminosa que, durante o dia, são obtidas através das fachadas: as fachadas são fontes de luz. As divisórias, que limitam os espaços necessários ao funcionamento doméstico, não têm relação direta com as paredes portantes; são membranas delgadas, 
isolantes ou não. A fachada fonte de luz não pode, por definição, suportar as lajes da casa. As lajes serão suportadas independentemente da fachada por pilares". (LE CORBUSIER; JEANNERET, Pierre, 1929, tradução nossa.)

Neste trecho, Le Corbusier e Pierre Jeanneret desconstroem a casa em partes inteligíveis, entendidas quase como que óbvias, para demonstrar como a mesma poderia ser industrializada.

Estrutura livre. Planta livre. Fachadas livres. Vedação com materiais leves para diminuir os custos de transporte e isolantes (térmico, acústico e impermeabilizante). Janelas (iluminação; ventilação, visibilidade). Telhados. Tetos jardim. Divisórias (móveis para esconder setores/nichos não usados durante o dia/noite; ) e interiores formados por armários industrializados instalados ao longo das paredes e também servindo de divisórias. Instalações prediais de climatização (calefação, refrigeração, ventilação).

Uma vez produzida por meio desse esquema, pela teoria dos autores, o arquiteto então teria a sua disposição uma planta livre - uma clara referência ao chão de fábrica — onde seriam distribuídas as divisórias necessárias e as lajes seriam formadas por um sistema de painéis e vigas apoiados sobre pilares concretados diretamente no solo, produzidos com materiais modernos, o concreto e o aço, que permitiam realizar com precisão a função estrutural da casa. Defendiam que a edificação construída racionalmente representa uma grande economia de espaços e de gastos com a construção, economia esta só atingida por meio da produção de elementos a serem fabricados industrialmente; mas a produção industrial, por sua vez, só pode ser viabilizada por meio da planta livre e da estrutura livre. Fazem uma breve comparação de como as habitações em série podem ter seus preços reduzidos em relação a casas artesanais na mesma proporção em que os automóveis industrializados estão para os artesanais; e acreditavam que era necessário encontrar e aplicar métodos novos e simples de construção e que fossem elaborados projetos que permitissem a estandardização, a industrialização, a taylorização.

As falas dos autores refletia a "revolução mental" de Taylor, quando considerava que a vida doméstica possui uma série de funções precisas que necessitam de espaços para acontecer; e que estas funções, que seguem uma lógica biológica (e mecanizada), se colocadas em linha, determinariam um jogo de superfícies e contiguidades resultando no projeto da habitação mínima e a organização das funções da vida doméstica resultaria num fenômeno de circulação. Novamente, a planta aparecia como a ferramenta que organiza o projeto e a vida para os arquitetos modernos. 
Quando se referiam à cidade e à necessidade de circulação, Le Corbusier e Pierre Jeanneret descreviam uma cidade que funcionava quase como uma engrenagem lubrificada, com as circulações de gente, de estradas e de meios de transporte, e instalações urbanas que funcionando como organismos mecânicos perfeitos, completada com outras pequenas partes que funcionariam como máquinas menores, holográfica da estrutura maior: a cidade e as casas conectadas como peças de uma engrenagem a um organismo maior.

Le Corbusier foi talvez o mais taylorista entre os arquitetos (Guillén, 2009), e foi bastante perspicaz em perceber como a arquitetura poderia se apropriar criativamente da engenharia para se renovar num momento em que a própria arquitetura era desvalorizada em relação à engenharia.

Guillén, em seu texto (2009) comenta como os arquitetos tinham uma preferência pela máquina, pela "lição da máquina" como metáfora para a nova teoria estética, mas que a industrialização talvez não tenha sido o fator mais importante na emergência do modernismo tendo, no entanto contribuído para tal de duas maneiras: primeiro, na provisão de novos materiais e técnicas de produção e, segundo, em possibilitar aos arquitetos experimentar novas concepções formais e espaciais, o que levou a construção de um novo estilo ou na renovação da arquitetura.

Mas o que talvez tenha impressionado mais os arquitetos entre os princípios enunciados por Taylor era a necessidade de separar a execução do trabalho da sua concepção, que deveria estar reservada a um departamento de planejamento. Até então, a concepção e a organização fabril era reservada para os profissionais da engenharia alinhados com as teorias da administração científica, enquanto para os arquitetos estava reservada uma atividade "de infeliz retrocesso" (nas palavras de Le Corbusier, s/d, citado por Guillén, 2009, p. 31).

Judith Merkle (1980) conta como, em 1910, uma questão pública sobre o aumento do valor das passagens de trens na Costa Leste dos EUA desencadeou a "mania por eficiência" que invadiu cada instância da vida nos EUA e se espraiou para o mundo ao longo do século XX.

As empresas de transporte ferroviário da Costa Leste dos EUA - que representavam o setor econômico à época que mais crescia e que também era visto como responsável pelo aumento do custo de vida da classe média - cogitavam em 1910 aumentar o preço das passagens, o que gerou um grande debate entre a população indignada, fomentado por notícias veiculadas todos os dias. No meio do debate, destacou-se Louis Brandeis, que advogava pela população e que propunha que as empresas poderiam cortar custos por meio de uma "reforma 
administrativa" ao invés de aumentar os preços. Sua estratégia tinha sido traçada junto com Frederick Winslow Taylor e equipe, que acabaram criando um nome para explicar a "profissão" que tinham desenvolvido e explicar o que seria aquela "reforma": a Administração Científica.

A disputa acabou por colocar o foco na teoria da administração científica, que passou a ser divulgada não só em revistas técnicas, mas em revistas femininas, revistas de variedades e até na imprensa sensacionalista, que não só descreviam e explicavam como a teoria funcionava, mas depois de algum tempo passaram também a especular sobre sua aplicabilidade. As teorias então passaram a ser conhecidas por todos e encontram ecos também entre os arquitetos modernos, se arrastando até os dias de hoje.

O famoso projeto de Margarete Schütte-Lihotzky para as cozinhas das habitações de Ernest May na Prefeitura de Frankfurt, que considerou um detalhado estudo sobre os movimentos necessários para a preparação de pratos, armazenamento e limpeza dos itens da cozinha em menos de $7 \mathrm{~m} 2$, mostra como os conceitos da fábrica invadiram a habitação e atravessaram o século XX. Ainda hoje, as cozinhas domésticas de qualquer área urbanizada do planeta possuem configuração espacial e organizacional aos moldes daquela, incentivadas até mesmo pelas revistas de decoração mais medíocres.

Merkle (1980) comenta que, mais do que as planilhas, os sistemas organizacionais e etc. foi na verdade a "revolução mental", o sistema geral de pensamento, o maior legado do taylorismo para a sociedade. Seus seguidores apresentaram as teorias com uma roupagem de filosofia para resolver administrativamente todos os problemas industriais mas também da vida, e possibilitar o avanço da sociedade industrial.

Os administradores científicos e seguidores, almejando uma "ordem racional para uma sociedade desestabilizada pela indústria” (Merkle, 1980, p. 81, tradução nossa) propunham na verdade uma ideia bastante instável: de que a eficiência social é análoga à eficiência da máquina e que a tão desejada ordem social imita os padrões de organização interna da máquina, sendo que um dos inevitáveis e diretos subprodutos da máquina era uma nova organização social. 


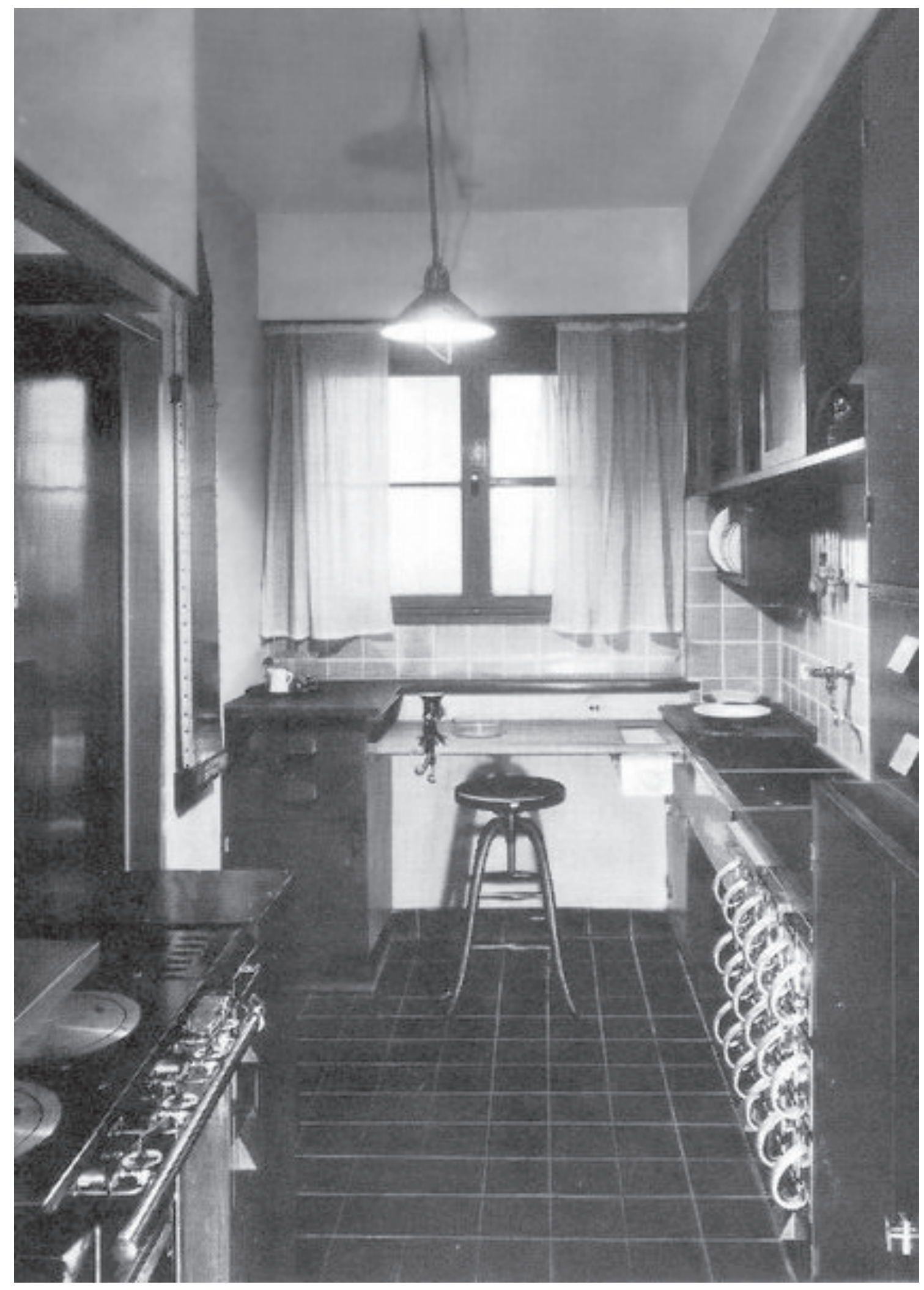

Cozinha de Frnakfurt. Projeto de Margarete Schütte-Lihotzky, em 1927. 
O ponto de Merkle na verdade é que só a ideologia da máquina, a ideologia da administração científica, não foi criada pelos administradores científicos, ou retirada da máquina somente naquele momento, mas estava latente na cultura industrial americana - muitas ideias de eficiência e organização eram antigas e nem estavam conectadas ao movimento da administração científica e o taylorismo foi a melhor oportunidade de conectar e amalgamar essas ideias e ainda transformá-las em ideologia - e que o argumento da administração científica ser um subproduto universal da máquina na verdade deriva da história dos engenheiros americanos.

Podemos lembrar que a atividade do engenheiro ou da engenharia nasceu dos estudos de resistência dos materiais, uma atividade que por princípio tentava extrair dos materiais e das formas sua melhor característica e desempenho para certas aplicações, estruturais por exemplo. Aplicar um material sob o ponto de vista de sua eficiência caracteriza muito o perfil do engenheiro. Mas o taylorismo foi mais do que essa busca por eficiência fabril, foi ideologia e sistema de controle social criada contra a influência de sindicatos, para treinar rapidamente mão-de-obra desqualificada e para criar um novo profissionalismo e mudar o perfil dos trabalhadores. Isto é, convencer e trazer a classe média para dentro da fábrica como mão-deobra - mais "favorável" ao patrão, diga-se de passagem - além de simplesmente ser um sistema organizacional para o chão de fábrica.

Foi, no entanto, com o desenvolvimento das teorias de administração científica que a fábrica se tornou local organizado, em que máquinas e humanos (autômatos da máquina) interagem quase como numa coreografia ensaiada. E foi por conta das teorias da administração científica que, entendemos, o termo "indústria" e "industrialização" adquirem um significado positivo para os arquitetos. Os problemas sociais, a "questão da habitação", o caos urbano (causados pela industrialização) poderiam igualmente ser resolvidos por meio de um projeto racional, por meio do bom desenho e por meio de ferramentas também industriais e capitalistas.

E da mesma maneira como a ideologia da administração científica teve ecos entre os cânones da arquitetura moderna, também os princípios daquela teoria teriam ecos no Brasil, trazidos ora pelos arquitetos da arquitetura internacional em suas passagens pelo Rio de Janeiro, ora por revistas e outras referências. Abelardo Riedy de Souza (1978) conta como ele próprio e os colegas tomaram conhecimento do trabalho de Le Corbusier, da Bauhaus, do trabalho de Warchavchik em São Paulo, do uso do concreto armado ou da estrutura metálica por meio de revistas trazidas pelos colegas. Aquelas novidades causaram uma insatisfação tão grande com 
o ensino na ENBA que repercutiu numa greve geral de estudantes, que não queriam mais os velhos mestres e os velhos métodos de ensino.

Abelardo relata como as atividades didáticas de sua graduação beiravam o ridículo: os docentes repetiam ano a ano o mesmos temas de pórticos, fontes, pavilhões de caça, isso quando não pediam projetos para "uma residência para uma família distinta" ou o projeto de "uma torre para residência de um filósofo numa ilha deserta" (tema proposto para a turma de Affonso Eduardo Reidy ainda estudante, conforme Abelardo).

O que significaria um projeto inútil ou fora da realidade? Se pensarmos em como as cidades em expansão e a necessidade da massa da população por habitação soavam para aqueles arquitetos, talvez seja esse o sentido de inutilidade a que o Abelardo se refere. Ou se pensarmos na indústria com suas ferramentas eficazes e seus métodos científicos, ou numa (falsa) moral (modernista) e objetividade de função e utilidade das coisas, em que o arquiteto quer ter uma função social e produzir coisas úteis para a massa da sociedade, então temos a crítica localizada de Abelardo. Mas é importante dizer que esses cacoetes modernistas repetidos por nossos personagens refletiam muito do imaginário taylorista, ainda que de maneira involuntária.

Com a nomeação de Lúcio Costa e a renovação do ensino na ENBA, os estudantes passaram então a estudar temas mais "práticos": casa mínima, posto de gasolina, grupos escolares, equipamentos de cozinha e banheiros, observado cuidadosamente o funcionamento dessas coisas, nas palavras de Abelardo.

"E esta já era uma coisa que até então desconhecíamos: a FUNÇÃO das coisas que éramos chamados a projetar. Era a função de cada cômodo; era a utilidade de uma cozinha, observando seu funcionamento e disposição de seu equipamento; era a interligação desses cômodos, mais os quartos e salas, que davam a funcionalidade da planta. Tinhamos uma planta livre, sem os cânones e a simetria até então obrigatórios" (Souza, 1978, p. 26).

Alguns dos estudantes que presenciaram a renovação do ensino da ENBA, como Hélio de Queiroz Duarte, Alcides Rocha Miranda e o próprio Abelardo de Souza, algum tempo depois, na década de 1950, se tornariam docentes na FAUUSP. 
Gapítulo 2

\section{A INDUSTRIALIZAÇÃo NO ENSINO DE PROJETO NA FAUUSP}


A introdução do relatório ${ }^{34}$ de 1963, sobre a implantação da sequência de DI na FAU, apresentava a fase de desenvolvimento em que se encontrava o país como o motivo que pressionaria a sociedade por soluções sobre novos e variados aspectos da produção. Com a reforma de 1962, a FAU se aproximava então do problema, uma vez que tanto os arquitetos tomavam para si a responsabilidade de uma resposta ao problema colocado pelo desenvolvimento industrial e, já que não era possível que a solução ficasse somente no plano profissional, era no ensino, ambiente livre das limitações da prática profissional, conforme o mesmo relatório, onde a contribuição ao desenvolvimento industrial se daria. Qual era o problema, apontado pelos arquitetos, colocado pelo desenvolvimento industrial? E qual seria a tal solução dada pelos arquitetos? E em que medida este mesmo discurso de modernização técnica e de confiança na indústria se refletia nas disciplinas de projeto de arquitetura?

Desde a criação do CREA, em 1933, os arquitetos já vinham se embrenhando numa discussão sobre a atividade profissional, defendendo que o projeto deveria ser atribuição privativa dos mesmos. E a vontade por uma Universidade de Projeto ${ }^{35}$ reforçava ainda a crença de que o desenvolvimento da sociedade passaria pelo lápis do arquiteto.

O artigo de O Dirigente Construtor ${ }^{36}$, apresentado no capítulo 1, apesar de não indicar autor, dialogava com a ideologia dos arquitetos ao apontar a necessidade de entrosamento entre a indústria e o arquiteto, o profissional mais indicado para introduzir características culturais no processo industrial e capaz de reformular desde objetos cotidianos até o edifício e os espaços urbanos, competente para o projeto total. E um depoimento posterior, de Artigas ${ }^{37}$, reforçava que as disciplinas de Desenho Industrial e de Comunicação Visual deveriam contribuir para formar o arquiteto para o "planejamento geral do meio ambiente".

\footnotetext{
$34 \quad$ FAUUSP, 1963 (a).

35 Conforme depoimento de Lucio Grinover para Juliano Pereira (2009).

36 Arquitetura de interiores. O Dirigente Construtor. São Paulo, v. 2, n. 7, p. 33-59, mai. 1966. Caderno Especial.

37 ARTIGAS, J.B.V. Depoimento: entrevista a Lívia Pedreira in XAVIER, 2003
} 
Como então o projeto total seria trabalhado pelo Departamento de Projeto? Ou, como as várias escalas de intervenção do arquiteto eram trabalhadas nas disciplinas de projeto. E, principalmente, como o desenvolvimento industrial estaria presente nas disciplinas de projeto de edificações. $\mathrm{O}$ ensino de desenho industrial não deveria ser transversal às disciplinas de projeto de edificações?

Levando em conta os outros episódios apresentados no Capítulo 1, o discurso da industrialização estaria presente nas disciplinas de projeto de arquitetura? Os docentes recorriam a métodos de desenho industrial no ensino sobre produção de arquitetura? Estaria presente em outras disciplinas que não as de projeto?

Ainda é necessário pontuar o seguinte: a industrialização da arquitetura não aparece nos autores $^{38}$ sobre a história do ensino da FAUUSP como um dos motivos que orientaram a criação desta ou de outra escola autônoma da arquitetura. Conforme Sylvia Ficher (2005, pág. 253-255), os anos 1940 foram marcados pela constituição de um novo perfil profissional de arquitetura - que se dedicava ao projeto, em detrimento da construção, e que entendia que a Arquitetura não deveria mais ser entendida como uma especialidade da Engenharia, mas uma atividade autônoma - e por uma mudança de orientação estética em direção ao modernismo. O $1^{\circ}$ Congresso Brasileiro de Arquitetos $^{39}$, em janeiro de 1945, promovido pelo IAB, "amadureceu" a consciência da necessidade de um ensino autônomo de Arquitetura, provavelmente como defesa de um ambiente próprio de exercício ideológico dos arquitetos; além disso, os debates no Congresso apontavam o urbanismo como um problema de arquitetura: deveria ser atribuição do arquiteto o projeto de espaços urbanos. Esse debate, que clamava por uma reforma do ensino de Arquitetura, culminaria com a criação das escolas autônomas de Arquitetura, entre elas a FAUUSP. E eram esses os temas que giravam em torno da criação da FAUUSP e da caracterização do novo profissional arquiteto. O tema da industrialização da arquitetura não fazia parte dos debates sobre autonomia do ensino nem estavam na gênese da fundação da FAUUSP.

Portanto, como a ideia do desenho industrial foi sendo incorporada nas disciplinas da FAUUSP até culminar na reforma de 1962? E como as disciplinas de projeto de arquitetura incorporaram essas ideias depois da reforma, até o final dos anos 1960 ?

38 Entre os autores que discutem o ensino de arquitetura no Brasil e a criação da FAUUSP, como Ficher (c.1972), Siqueira (2009) e Pereira (2009).

39 Congresso Brasileiro de Arquitetos, 1º 1945. Anais. São Paulo: IAB, 1945. 


\section{O primeiro regulamento da FAUUSP}

A aprovação do primeiro regulamento ${ }^{40}$ da FAUUSP, em outubro de 1955, incentivou que docentes e discentes iniciassem um debate, que se estendeu para os anos seguintes, sobre o cotidiano da escola e, principalmente, sobre a formação dos arquitetos.

Já em setembro de 1956, o Gfau organizava um seminário ${ }^{41}$ discutindo a expectativa dos estudantes em relação aos métodos didáticos, e pediam que "as matérias científicas devem ser ensinadas como surgiram: diante de problemas reais foram concebidas idéias que explicavam estes fenômenos". O ensino praticado até então estava limitado aos conhecimentos transmitidos nas respectivas cadeiras que, ainda que de alto padrão, na opinião dos estudantes, não considerava as "situações problemas" com que os arquitetos se deparariam em sua prática profissional. Os estudantes não só acusavam estar as cadeiras impregnadas de resquícios do ensino politécnico, mas culpavam o próprio ensino na FAUUSP como responsável pelas dificuldades que acreditavam enfrentar o arquiteto nas suas atividades profissionais. Diante disso, e não por acaso, a FAU teria encarregado em 1957 uma comissão de docentes para "examinar e propor as reformas julgadas necessárias para o aperfeiçoamento do ensino" ${ }^{\text {"42 }}$, composta por Rino Levi, J.B. Vilanova Artigas, Abelardo de Souza e Hélio Duarte. Mas os trabalhos não tiveram sucesso.

O novo regulamento estabeleceu nova organização entre as disciplinas, re-numeradas e agrupadas em cadeiras, para as quais seriam finalmente abertos concursos para a provisão de professores catedráticos. Possibilitou ${ }^{43}$ também a revisão dos horários de aula, da quantidade de aulas por disciplina e a revisão dos programas didáticos de cada disciplina, esta última a ser elaborada em conjunto pelas cadeiras afins, obrigadas pelo novo regulamento a se agruparem em departamentos., que deveriam ser seis: Departamento de Física e Matemática, Departamento de Construções, Departamento de Estruturas, Departamento de História de Arquitetura, Departamento de Arquitetura e Departamento de Economia e Matéria Legal.

Ao que tudo indica ${ }^{44}$, a criação desses departamentos ficou só no papel. E, na prática, a

40 São Paulo (Estado). Lei n. 3.233, de 27 de outubro de 1955, que dispões sobre o regulamento da Faculdade de Arquitetura e Urbanismo, da Universidade de São Paulo, criada pela Lei n. 104, de 21 de junho de 1948, e dá outras providências.

41 GFAU, 1956

42 MILLAN, 1962.

43 Conforme Documento 1.0559.03 do Arquivo Documental Lina Bo Bardi, do Instituto Lina Bo e P.M. Bardi: uma carta de 7 de dezembro de 1955, do Prof. Lysandro Mele Pereira da Silva, enviada ao corpo docente da FAUUSP reiterando o que foi deliberado durante a reunião do dia 6 de dezembro de 1955 .

44 Somente a correspondência do Prof. Lisandro faz menção à criação desses departamentos. E somente os programas de 1963 a 1966 contêm indicação sobre departamentos; não há documentos de 1955 que colabore 
reorganização de cadeiras e dos programas didáticos introduziu poucas modificações no currículo utilizado desde $1948^{45}$.

\section{De 1948 a 1955}

Nesse período, não só é rara a menção ao tema da industrialização como são bastante escassos os documentos e ementas da FAUUSP. Apesar disso, acreditamos ${ }^{46}$ que cada uma foi elaborada pelo próprio docente responsável, talvez com a colaboração dos assistentes, o que indica que cada conteúdo passado tivesse muito da personalidade e da construção profissional de cada docente.

E, ao contrário do curso de Engenheiro-Arquiteto da Escola Politécnica ${ }^{47}$ ao final de sua existência, no curso de Arquiteto havia cadeiras de composição desde o primeiro ano, além de cadeiras auxiliares sobre desenho arquitetônico, desenho artístico, plástica e história da arquitetura, ainda que a abordagem fosse fachadista e instrumental. Conforme depoimento de Jon Maitrejean ${ }^{48}$, formado em 1953, muitas aulas de plásticas se resumiam a elaborar modelos de volutas e cornijas, ou outros detalhes historicistas, em argila ou plastilina. E as aulas de história se resumiam a repertório de estilos e a uma sequência linear de períodos culturais da humanidade.

O curso possuía traços do ensino politécnico, com cadeiras de tecnologia, cálculo e geometria, mas também convivia com a presença da orientação das Belas Artes.

\section{PRIMEIRO ANO}

"Composição de Arquitetura - Pequenas Composições I. Desenho Arquitetônico" era uma disciplina introdutória à atividade de projeto e a ementa previa a iniciação a um repertório de materiais de construção, aos elementos construtivos do ponto de vista funcional e plástico e aos estudos de layout de ambientes - internos e externos de uma residência - e de implantação - situação, orientação, vizinhança.

sua existência.

45 Conforme depoimento da Arquiteta Marlene Picarelli concedido em 13 de março de 2015.

46 A Lei n. 104 de 21 de junho de 1948, que criava a FAUUSP, estava baseada no decreto-lei 7918, de 31 de agosto de 1945, que organizava a Faculdade Nacional de Arquitetura, não apontava quais seriam as cadeiras do recém criado curso de Arquitetura mas, ao invés disso, determinava que um colegiado de catedráticos definisse o regimento interno e o regime didático da escola. De modo similar, acreditamos a ementa de cada cadeira que a Lei de criação da FAU definia, fosse elaborada pelo seu docente responsável.

47 Que se pode verificar em FICHER, 2005.

48 Entrevista concedida em 12 de setembro de 2015. 


\section{Grade curricular do período 1948-1955}

\begin{tabular}{|c|c|c|c|}
\hline \multirow[t]{14}{*}{$1^{\circ}$ ano } & \multirow[t]{2}{*}{$\begin{array}{l}\text { Matemática } \\
\text { superior }\end{array}$} & 1948 & $\begin{array}{l}\text { João Augusto Breves Filho } \\
\text { Nelson da Silveira Leme }\end{array}$ \\
\hline & & $1953 / 55$ & João Octávio M. Camargo \\
\hline & \multirow[t]{2}{*}{ Nomografia } & $1948 / 53 / 55$ & Eurico Cerruti \\
\hline & & 1955 & Nelson da Silveira Leme ${ }^{\mathrm{b}}$ \\
\hline & $\begin{array}{l}\text { Geometria descritiva e } \\
\text { aplicações }\end{array}$ & $1948 / 53$ & Pedro Moacyr do Amaral Cruz \\
\hline & \multirow[t]{3}{*}{ Arquitetura analítica } & $1948 / 53$ & Bruno Simões Magro \\
\hline & & 1948 & Ariosto Mila ${ }^{\mathrm{a}}$ \\
\hline & & 1955 & Enoch de Rocha Milab \\
\hline & \multirow{2}{*}{$\begin{array}{l}\text { Composição de } \\
\text { arquitetura. } \\
\text { Pequenas composições I } \\
\text { (Desenho arquitetônico) }\end{array}$} & $1953 / 55$ & Zenon Lotufo \\
\hline & & $1950-53$ & Ícaro de Castro Mello $^{\mathrm{c}}$ \\
\hline & \multirow[t]{2}{*}{ Plástica I } & 1948 & Felisberto Ranzini \\
\hline & & $1950-55$ & Caetano Fraccaroli ${ }^{\mathrm{C}}$ \\
\hline & \multirow[t]{2}{*}{ Desenho artístico I } & 1948 & José Maria da Silva Neves \\
\hline & & $1953 / 55$ & Vera Helena Amaral $^{\mathrm{d}}$ \\
\hline \multirow[t]{16}{*}{$2^{\circ}$ ano } & \multirow[t]{2}{*}{ Mecânica racional } & $1953 / 55$ & João Augusto Breves Filho \\
\hline & & 1955 & Nelson da Silveira Leme ${ }^{\mathrm{b}}$ \\
\hline & \multirow[t]{2}{*}{ Materiais de construção } & $1953 / 55$ & Ary Frederico Torres \\
\hline & & 1955 & Vicente Chiaverini \\
\hline & \multirow{2}{*}{$\begin{array}{l}\text { Topografia. Elementos de } \\
\text { astronomia e posição }\end{array}$} & $1953 / 55$ & Henrique Jorge Guedes \\
\hline & & 1955 & Paulo Sampaio Góes ${ }^{b}$ \\
\hline & \multirow[t]{3}{*}{ Teoria da arquitetura } & 1953 & Miguel Badra Jr. \\
\hline & & 1955 & Eduardo Coronab \\
\hline & & 1955 & Carlos Alberto de Cerqueira Lemos ${ }^{b}$ \\
\hline & \multicolumn{2}{|c|}{ Composição de arquitetura. 1953} & João Baptista Vilanova Artigas \\
\hline & \multirow[t]{2}{*}{ Pequenas composições II } & 1955 & Abelardo Riedy de Souzab \\
\hline & & 1955 & Jon Andoni Vergareche Maitrejean \\
\hline & \multirow[t]{2}{*}{ Desenho artístico II } & 1953 & Archimedes Dutra \\
\hline & & 1955 & Vera Helena Amaral $^{\mathrm{b}}$ \\
\hline & \multirow[t]{2}{*}{ Plástica II } & 1953 & Vicente Larocca \\
\hline & & 1955 & Bassano Vacarini ${ }^{b}$ \\
\hline
\end{tabular}


Em Desenho Artístico, uma leitura geral da ementa aponta para uma abordagem livre da prática artística, de experimentação de materiais, técnicas e linguagens possíveis para a representação de objetos, formas e volumes e ao mesmo tempo para um uso profissional da representação artística nas apresentações de trabalhos arquitetônicos. Há uma sutil indicação de como a disciplina instrumentalizava os estudantes para a prática da composição fachadista, um compreensível reminiscência do ensino politécnico num curso recém-inaugurado.

\section{SEGUNDO ANO}

Em Materiais de Construção, para o $2^{\circ}$ ano, os materiais eram abordados do ponto de vista tecnológico de suas propriedades, produção e composição, entre os quais estavam os aglomerantes, os agregados, as argamassas, os materiais cerâmicos, as madeiras, os materiais asfálticos e os materiais metálicos. E o estudo do concreto merecia atenção especial. Como atividades práticas, eram realizados ensaios tecnológicos com aglomerantes, madeiras, metais e materiais cerâmicos, assim como com concretos. Ao menos em 1953 e 1955, conforme documentos encontrados, Ary Frederico Torres foi o docente responsável por Materiais de Construção.

Em Composição de Arquitetura - Pequenas Composições II dava-se continuidade aos estudos de projeto do $1^{\circ}$ ano, com o aprofundamento do estudo da representação dos detalhes construtivos de fundações, vedos, revestimentos e instalações prediais (água, energia, etc), esquadrias, aplicação das noções de insolação e das restrições legais municipais ${ }^{49}$. Foram responsáveis por essa cadeira não só Artigas, mas também Abelardo de Souza assistido por Jon Maitrejean.

E Plástica, ministrada para todos os anos da graduação ${ }^{50}$ nesta primeira fase, ao contrário, era uma disciplina que visava desenvolver no estudante o domínio das técnicas artísticas, um pouco mais voltada à instrumentação do que à livre criação.

49 À época, o Código de Obras Artur Sabóia de São Paulo.

50 As ementas de Plástica I, II, IV e V foram localizadas no arquivo do Departamento de História e Estética do Projeto da FAUUSP. No entanto não havia nenhuma indicação de ter existido uma disciplina Plástica III. A indicação de que essa disciplina foi ministrada para o $3^{\circ}$ ano da graduação foi encontrada na Lei de criação da FAUUSP e no documento n. 1.0559.02 do Arquivo Documental Lina Bo Bardi, do Instituto Lina Bo e P.M. Bardi. 


\section{Grade curricular do período 1948-1955}

\begin{tabular}{|c|c|c|c|}
\hline \multirow[t]{8}{*}{$3^{\circ}$ ano } & Física geral e aplicada & $\begin{array}{l}1953 / 55 \\
1955\end{array}$ & $\begin{array}{l}\text { Luiz Cintra do Prado } \\
\text { Luiz de Queirós Orsini }\end{array}$ \\
\hline & $\begin{array}{l}\text { Resistência dos materiais } \\
\text { e estabilidade das } \\
\text { construções }\end{array}$ & $\begin{array}{l}1953 / 55 \\
1950-55 \\
1955\end{array}$ & $\begin{array}{l}\text { Hyppólito de Macedo Van Langendonck } \\
\text { Augusto Carlos de Vasconcelos }{ }^{\text {e }} \\
\text { Paulo Novak Filho }\end{array}$ \\
\hline & $\begin{array}{l}\text { Geometria descritiva e } \\
\text { aplicações }\end{array}$ & $1948 / 53$ & Pedro Moacyr do Amaral Cruz \\
\hline & Construções civis & $\begin{array}{l}1953 / 55 \\
1955\end{array}$ & $\begin{array}{l}\text { Ariosto Mila } \\
\text { Guilherme do Amaral Lyrab }\end{array}$ \\
\hline & $\begin{array}{l}\text { Elementos de mecânica } \\
\text { dos solos. Fundações }\end{array}$ & $\begin{array}{l}1953 \\
1955\end{array}$ & $\begin{array}{l}\text { Odair Grillo } \\
\text { Victor Froilano Bachmann de Mellob }\end{array}$ \\
\hline & $\begin{array}{l}\text { Composição de arquitetura. } \\
\text { Grandes composições I }\end{array}$ & $\begin{array}{l}1953 \\
1955 \\
1955\end{array}$ & $\begin{array}{l}\text { Hélio de Queirós Duarte } \\
\text { Ícaro de Castro Mellob } \\
\text { Oswaldo Corrêa Gonçalves }\end{array}$ \\
\hline & Composição decorativa $I^{\mathrm{b}}$ & $1953 / 55$ & José Maria da Silva Neves \\
\hline & Plástica III ${ }^{\mathrm{b}}$ & 1955 & Caetano Fraccaroli $^{\mathrm{b}}$ \\
\hline \multirow[t]{8}{*}{$4^{\circ}$ ano } & Concreto simples e armado & $\begin{array}{l}1953 \\
1955 \\
1955\end{array}$ & $\begin{array}{l}\text { Fernando de Oliveira Escorel } \\
\text { José Carlos de Figueiredo Ferraz }^{\mathrm{b}} \\
\text { Alberto R. M. van Langendonck }\end{array}$ \\
\hline & Grandes estruturas & $\begin{array}{l}1953 / 55 \\
1955\end{array}$ & $\begin{array}{l}\text { Pedro Bento José Gravina } \\
\text { Sérgio Fraccaroli }^{\mathrm{b}}\end{array}$ \\
\hline & $\begin{array}{l}\text { Hidráulica. Hidráulica } \\
\text { urbana e saneamento }\end{array}$ & $\begin{array}{l}1953 / 55 \\
1955\end{array}$ & $\begin{array}{l}\text { Lysandro Mele Pereira da Silva } \\
\text { Paulo Sampaio Wilken }\end{array}$ \\
\hline & $\begin{array}{l}\text { Economia política. } \\
\text { Estatística aplicada. } \\
\text { Organização administrativa }\end{array}$ & $\begin{array}{l}1953 \\
1955 \\
1955\end{array}$ & $\begin{array}{l}\text { Carlos Alberto Vanzolini } \\
\text { Mário Wagner Vieira da Cunha }{ }^{\text {b }} \\
\text { Carlos Pereira de Castro }^{\text {b }}\end{array}$ \\
\hline & Legislação e contabilidade & $\begin{array}{l}1953 / 55 \\
1955\end{array}$ & $\begin{array}{l}\text { Américo Oswaldo Campliglia } \\
\text { Carlos Pereira de Castrob }\end{array}$ \\
\hline & $\begin{array}{l}\text { Composição de arquitetura. } \\
\text { Grandes composições II }\end{array}$ & $\begin{array}{l}1953 \\
1955 \\
1955\end{array}$ & $\begin{array}{l}\text { Elisário da Cunha Bahiana } \\
\text { Hélio de Queirós Duarte }^{\mathrm{b}} \\
\text { Plínio Croce }\end{array}$ \\
\hline & Plástica IV & $\begin{array}{l}1953 \\
1955\end{array}$ & $\begin{array}{l}\text { Alfredo Oliani } \\
\text { Ernest Robert de Carvalho Mange }\end{array}$ \\
\hline & Composição decorativa II $^{\mathrm{b}}$ & 1955 & Jacob Mauricio Ruchti $^{\mathrm{b}}$ \\
\hline
\end{tabular}




\section{TERCEIRO ANO}

A disciplina de Física Geral e Aplicada, ministrada por Luiz Cintra do Prado para $3^{\circ}$ ano, era dividida nas matérias de iluminação, acústica, eletricidade e termologia, estudadas tanto do ponto de vista teórico, com a resolução de problemas e exercícios numéricos, como do ponto de vista prático e instrumental, com exercícios de anteprojeto arquitetônico - de iluminação natural e artificial, acústico, de instalação elétrica, insolação, de renovação de ar, etc - e visitas a edifícios e canteiros de obra. Recomendava-se inclusive um esforço dos estudantes em entrosar as matérias desta com as outras disciplinas na elaboração do projeto. Luiz Cintra do Prado, responsável por esta cadeira, tinha um apreço pelo estudo do desempenho e característica física dos materiais de construção e teve um papel fundamental durante a década de 1960 (que apresentaremos no próximo item) em indicar estudantes para intercâmbios no Centro Científico e Tecnológico da Construção, o CSTB ${ }^{51}$, na França. Até 1962, "Física Geral e Aplicada", transformada na Cadeira 4, manteve o mesmo programa didático e exercícios práticos trabalhados durante a primeira fase curricular. Nesta cadeira, as matérias de iluminação, eletricidade, acústica e termologia ainda eram estudadas do ponto de vista da física e da sua aplicação no projeto de arquitetura.

Construções Civis era uma disciplina de repertório tanto do ponto de vista da edificação, isto é, dos elementos construtivos da edificação, como do canteiro de obras com seus processos e técnicas construtivas. Ariosto Mila, que ficou responsável pela cadeira até final da década de 1960, também apresentava um repertório sobre os equipamentos e dispositivos eletrônicos que invadiam as casas e a vida moderna e seu impacto no projeto de arquitetura e nas instalações prediais, como água, gás e energia.

Em Composição de Arquitetura - Grandes Composições I, o ano era dividido em duas partes: o primeiro semestre era dedicado a esboços ligeiros de anteprojetos de programa flexível para dar aos estudantes conceitos básicos de organização do trabalho do arquiteto, estruturação de partidos, ordenação de grandes massas, circulações coletivas, entrosamento dos elementos estruturais e as instalações gerais na composição. No segundo semestre, os estudantes elaboravam projetos de uma unidade comercial, uma unidade de saúde e uma unidade escolar.

No $3^{\circ}$ ano, a ementa de Composição Decorativa indicava que seriam estudados os conceitos (proporção, equilíbrio, contraste, harmonia), a evolução e as tendências da arte decorativa. Também eram objeto de estudo a cor, tanto do ponto de vista psicológico como do químico,

51 Centre Scientifique et Technique du Bâtiment. 
os materiais e o mobiliário empregados na decoração de interiores, do ponto de vista histórico e dos aspectos construtivos. A ementa sugere uma abordagem estilística da composição decorativa voltada principalmente para a decoração de um interior.

\section{QUARTO ANO}

O $4^{\circ}$ ano era iniciado com a disciplina de Concreto Simples e Armado, em que eram apresentados aos estudantes o material concreto, sua constituição e propriedades, e o material concreto associado solidariamente ao aço, sua composição, característica, resistência, detalhes construtivos, cálculo e dimensionamento em conformidade com as normas correntes.

Também eram apresentadas aos estudantes as "aplicações do concreto armado nas grandes composições; o partido dos arcos, das cascas e das peças de concreto pré-moldado e protendido". Subentende-se da ementa que eram ainda abordados teoricamente a "organização e instalação dos serviços" na obra e o "preparo e montagem das armaduras; preparo, transporte e lançamento do concreto; adensamento e cura".

Paralelamente, os estudantes cursavam a disciplina de Grandes Estruturas, em que provavelmente se dava continuidade aos estudos iniciados em Resistência do Materiais, no $3^{\circ}$ ano. Em Grandes Estruturas eram estudados os sistemas e as deformações elásticas; os sistemas hiperestáticos planos (treliças, pórticos, arcos e vigas) e os sistemas espaciais (cúpulas, treliças espaciais, abóbadas e cascas). Se havia uma disciplina dedicada ao estudo do concreto armado havia também uma disciplina de estudos sobre o comportamento das estruturas em geral.

Apesar de não possuir ementa, Composição Decorativa também fazia parte do currículo do $4^{\circ}$ $\mathrm{ano}^{52}$. Ao menos em 1955, o responsável pela aulas para o $4^{\circ}$ ano foi Jacob Ruchti ${ }^{53}$, arquiteto que também lecionou composição plástica no IAC, o Instituto de Arte Contemporânea do MASP, conforme Ethel Leon (2006).

Composição de Arquitetura - Grandes Composições II, no $4^{\circ}$ ano, era dividida em duas parte, no primeiro semestre seria lecionada a matéria de "projetos completos sobre temas de conjuntos de edifícios" e no segundo semestre "projetos de edifícios de grandes proporções isolados ou em conjuntos".

52 Conforme São Paulo (Estado). Lei n. 104 de 21 de junho de 1948, que cria a Faculdade de Arquitetura e Urbanismo da Universidade de São Paulo e dá outras providências.

53 Conforme Doc. n. 1.0559.02 do Arquivo Documental Lina Bo Bardi, do Instituto Lina Bo e P.M. Bardi. 


\section{Grade curricular do período 1948-1955}

\begin{tabular}{|c|c|c|c|}
\hline \multirow[t]{7}{*}{$5^{\circ}$ ano } & História da arte. Estética & $\begin{array}{l}1953 \\
1955\end{array}$ & $\begin{array}{l}\text { Lourival Gomes Machado } \\
\text { Flávio L. Motta }\end{array}$ \\
\hline & Arquitetura no Brasil & $\begin{array}{l}1953 \\
1955\end{array}$ & $\begin{array}{l}\text { Carlos Alberto Gomes Cardim Filho } \\
\text { Eduardo Augusto Kneese de Mello }\end{array}$ \\
\hline & $\begin{array}{l}\text { Composição de arquitetu } \\
\text { Grandes } \\
\text { composições } \mathrm{III}^{\mathrm{b} / \mathrm{f}}\end{array}$ & $\begin{array}{l}1953 \\
1954-55 \\
1954-55 \\
1955 \\
1955\end{array}$ & $\begin{array}{l}\text { José Vicente Vicari } \\
\text { Ícaro de Castro Mello }^{\mathrm{c}} \\
\text { Oswaldo Correa Gonçalves } \\
\text { Rino Levig }^{\mathrm{g}} \\
\text { Roberto Cerqueira Césarg }\end{array}$ \\
\hline & Plástica V & $\begin{array}{l}1953 \\
1955\end{array}$ & $\begin{array}{l}\text { José Vicente Vicari }^{\mathrm{h}} \\
\text { Ernest Robert Carvalho Mange }^{\mathrm{b}}\end{array}$ \\
\hline & Composição decorativa ${ }^{b}$ & $\begin{array}{l}1953 \\
1954 \\
1955\end{array}$ & $\begin{array}{l}\text { Antônio Paim Vieira } \\
\text { Alcides Aquila da Rocha Miranda }{ }^{\text {b }} \\
\text { Lina Bo Bardi }\end{array}$ \\
\hline & Urbanismo & $\begin{array}{l}1953 / 55 \\
1955\end{array}$ & $\begin{array}{l}\text { Luiz Ignácio Romeiro de Anhaia Mello } \\
\text { Milton Carlos Ghiraldini }\end{array}$ \\
\hline & Arquitetura paisagística & $\begin{array}{l}1953 / 55 \\
1955\end{array}$ & $\begin{array}{l}\text { Roberto Coelho Cardozo } \\
\text { Daisy Ruth Igel Hoffenberg }\end{array}$ \\
\hline
\end{tabular}


O temas propostos para os estudantes compreendiam edifícios governamentais; edifícios para a segurança nacional e pública; edifícios para educação física e intelectual; edifícios religiosos; edifícios funerários; edifícios para os meios de transporte; edifícios de comércio e serviço; edifícios para a mídia impressa e radiofônica; edifícios para saúde e assistência social; edifícios de repouso e lazer, entre outros. O foco do trabalho era muito mais a construção do programa arquitetônico e a elaboração plástica do aspecto final do edifício.

A grade do $4^{\circ}$ ano era finalizada com Plástica IV que era voltada à prática das técnicas artísticas. Eram elaboradas então maquetes em barro, gesso ou madeira dos projetos executados nas aulas de Pequenas e Grandes Composições de Arquitetura. Fazia ainda parte do programa o estudo de relevo, o relevo policromo, o baixo-relevo e o grafite e suas aplicações decorativas na arquitetura, além do gesso e outros materiais de fundição para a elaboração de estatuária.

\section{QUINTO ANO}

Composição Decorativa para o $5^{\circ}$ ano, ao menos em 1953, apresenta um repertório de elementos e objetos da composição decorativa - tapetes e tapeçarias, tecidos, vitral mosaico e vidro e materiais cerâmicos - e dos locais onde tais elementos podem ser aplicados na decoração, tais como casas comerciais, restaurantes e hotéis, edificios religiosos e educacionais e casas de diversão (teatros e cinemas, etc). A ementa ainda aponta "métodos e praxes adotados" na composição decorativa, texto bastante sugestivo de como o docente, Antonio Paim Vieira, talvez trabalhasse o conteúdo de modo estilístico e maneirista.

Em 1955 e 1956, Lina Bo Bardi seria contratada em substituição a Alcides Áquila da Rocha Miranda $^{54}$. Possivelmente, foi em Composição Decorativa com Lina Bo Bardi que os estudantes tiveram o primeiro contato com o desenho industrial. Voltaremos a esse tema no próximo sub-item.

Por fim, Composição de Arquitetura - Grandes Composições III era a disciplina final que sintetizava o curso de projeto da graduação, sendo organizada em cinco grupos de atividades. Os três primeiros consistiam de revisões, exercícios construtivos e aulas expositivas.

A quarta parte de atividades da disciplina consistia num projeto-tese completo sobre arquitetura, a ser elaborado individualmente durante o segundo semestre da disciplina, cujo tema deveria ser original e de particular interesse e importância, escolhido pelo próprio

$54 \quad$ Conforme documentos número 1.552 .5 e 1.553.1 do Arquivo Documental Lina Bo Bardi, do Instituto Lina Bo e P.M. Bardi. 
estudante com o acordo dos docentes. Ou seja, era a tese final, que deveria ser um projeto “completo como execução artística (desenhos, gráficos, aquarela, carvão, etc), como execução técnica (estruturas, instalações, eventuais cálculos, detalhes, etc), e como estudo administrativo (memorial, especificações, etc)".

A quinta parte compreendia atividades extra-classe, como visitas a edifícios em funcionamento ou em fase de execução; excursões a sítios históricos, artísticos, arquitetônicos e urbanísticos nacionais ou internacionais, durante o período de férias ${ }^{55}$, complementadas com projeções de filmes documentários e fotografias; exposição dos trabalhos discentes na Faculdade ou locais públicos; e publicação dos melhores trabalhos, relatórios e outros estudos realizados pelos estudantes.

\section{Lina Bo Bardi na FAUUSP}

Algumas anotações à mão e alguns desenhos formam talvez uma sequência de raciocínio que seria desenvolvida em sala. Para a primeira aula, "o que é composição decorativa" e "desenho industrial", com alguns tópicos sobre produção em série, restauro e ambientação e desenhos esquemáticos de modulação e tamanhos mínimos. Para a segunda aula, uma comparação entre artesanato e indústria, mais tópicos sobre ambientação, historicismo e "responsabilidade moral" do "arquiteto na sociedade". Para as próximas, aulas sobre medidas e ângulos em ergonomia e "desenho industrial e arquitetura de interiores", quando então os estudantes desenvolveriam o projeto para uma casa pequena, "uma residência do tipo mínimo" 56 e eram, ao que parece, incentivados a fazer visitas em fábricas (do quê? Quais tipos?).

Diferentemente dos "métodos e praxes adotados" na composição, do histórico da decoração e do repertório de tapeçarias, vidrarias e papéis de parede, entre outros, presentes nas ementas ora de Antonio Paim Vieira ${ }^{57}$ ora de José Maria da Silva Neves, Lina Bo Bardi trouxe para aula, em 1955 (ou seria 1956 ${ }^{58}$ ?), conceitos que destoavam do ensino praticado até então. Além de uma compreensão histórica sobre a diferença entre artesanato e produção industrial - diferentemente do que entenderiam alguns docentes, como Ariosto Mila, como exposto mais a frente - havia nas aulas de Lina ensinamentos sobre desenho direcionado para a produção, com conceitos de modulação, tamanhos mínimos e requisitos de ergonomia que só

\footnotetext{
55 Sobre as viagens dos estudantes da FAUUSP até 1962, ver SODRÉ, 2010.

56 As aspas foram transcritas de "Anotações de aula", documento de 7 páginas número 1.551.2, data entre 1955 e 1956, do Arquivo Documental Lina Bo Bardi, do Instituto Lina Bo e P.M. Bardi.

57 Docente de Composição Decorativa para o $5^{\circ}$ ano em 1953.

58 O documento número 1.551.2 não possui data. Foi escrito entre 1955 e 1956, anos em que Lina deu aula na FAUUSP.
} 
voltariam a aparecer nas aulas de projeto em 1962.

Depois da exoneração de Alcides Áquila da Rocha Miranda ${ }^{59}$, Lina seria contratada por Lysandro Mele Pereira da Silva, então diretor da FAU, possivelmente por indicação de Abelardo Riedy de Souza, arquiteto muito seu amigo que, não só a convidava para trabalhos em conjunto, conforme depoimento de Ana Carboncini ${ }^{60}$, teve muitos artigos e projetos publicados em Habitat (Constantino, 2004, pág. 70) e participou da editoria de arquitetura da revista até março de 1955 (Dedecca, 2012, pág.104). Lina iniciava em maio de 1955 suas aulas para a quarta turma de formandos da escola ${ }^{61}$ :

\author{
Akira Luiz Fukugava \\ Armando Rebollo \\ Ary Albano \\ Cláudio Celso Bruschini Ribeiro \\ Dario Imparato \\ Edoardo Rosso \\ Francisco Mariano de Moraes Rodrigues Torres \\ Gilbert Othoniel Toni \\ Hidéo Maeda \\ Innocencio Patrocinio \\ José Luiz Ferreira Fleury de Oliveira \\ Luiz Monzoni Pinheiro Santos \\ Marianilza Brasil de Oliveira \\ Miguel Feres \\ Miranda Maria Esmeralda Martinelli \\ Nestor Goulart Reis Filho \\ Oduvaldo Ferreira \\ Osmar Antonio Tosi \\ Roberto Fonseca de Carvalho \\ Rodolpho Almeida Fernandes \\ Rosa Grena Alembick \\ Rubens Salvador Trindade Magliano \\ Shioju Mukai \\ Sigfrido Martin Rieber \\ Yoshimasa Kimacei
}

Até aquele momento, vigorava na FAU o primeiro regime didático estabelecido pela lei que a

59 Conforme documento número 1.552.5 do Arquivo Documental Lina Bo Bardi, do Instituto Lina Bo e P.M. Bardi.

60 Diretora do Instituto Lina Bo e P.M. Bardi, que concedeu entrevista em 13 de março de 2015. Anna Maria Carboncini Masini não soube precisar quais trabalhos Lina Bo e Aberlardo de Souza realizaram em conjunto.

61 "FAUUSP / Relação da aulas dadas durante o primeiro semestre (18 de maio a 15 de junho) pelo Prof. Achilina Bo Bardi”. Documento número 1.557.1 
criara $^{62}$, que determinava Composição Decorativa como uma disciplina ministrada para os três últimos anos da graduação, do $3^{\circ}$ ano até o $5^{\circ}$ ano. E eram três os docentes de Composição Decorativa até 1955: José Maria da Silva Neves para o $3^{\circ}$ ano, docente que possuía vínculo com a Universidade, Jacob Maurício Ruchti para o $4^{\circ}$ ano e Lina Bo para o $5^{\circ}$ ano, contratados para exercício temporário da docência. Com a aprovação do primeiro regulamento no final de 1955, Composição Decorativa passava a ser ministrada somente para o $3^{\circ}$ e $4^{\circ}$ ano; mas o $5^{\circ}$ ano de 1956 ainda deveria ter Composição Decorativa como adaptação curricular e, em abril de $1956^{63}$, a contratação de Lina foi prorrogada por mais aquele ano.

Antes da prorrogação, ainda em dezembro de 1955, o diretor da FAUUSP Prof. Lysandro Mele Pereira da Silva solicitava ${ }^{64}$ que os docentes aproveitassem o novo regimento para uma revisão de suas cadeiras. Lina respondeu ${ }^{65}$ solicitando o acréscimo mínimo de 1 hora às horas semanais para as aulas de teoria. Nessas aulas, sua intenção era desenvolver temas como: técnica profissional de planejamento para "decoração", análise da decoração dos vários tipos de edifício, questões específicas do "desenho industrial" e breve história dos estilos decorativos. Para as aulas práticas seriam aplicados os conhecimentos num projeto completo de decoração, quando também os estudantes desenvolveriam a maquete de algum dos móveis projetados. Lina comunica que seriam programadas visitas técnicas à fábricas e oficinas para demonstração dos processos de trabalho e execução. Também era intenção de Lina organizar na sala de aula, numa parede, um mostruário dos materiais de decoração (tecidos, revestimentos, madeiras, cerâmica, metal, etc). Seria a vontade de montar um laboratório na mesma linha do Studio Palma?

A carta é escrita provavelmente depois de um balanço que Lina fez sobre sua prática docente em 1955. Lina avaliava que o desempenho dos alunos tinha sido ótimo sob qualquer ponto de vista, mas o desenvolvimento das aulas era prejudicado pelo pouco espaço da sala e pelo pouco tempo de aula. Ao fim da carta, Lina ainda solicitava a contratação de um assistente para si, para melhor atender os alunos.

62 São Paulo (Estado). Lei n. 104 de 21 de junho de 1948, que cria a Faculdade de Arquitetura e Urbanismo da Universidade de São Paulo e dá outras providências.

63 Conforme documento número 1.560.1 do Arquivo Documental Lina Bo Bardi, do Instituto Lina Bo e P.M. Bardi.

64 Conforme Documento 1.559.3 do Arquivo Documental Lina Bo Bardi, do Instituto Lina Bo e P.M. Bardi: uma carta de 7 de dezembro de 1955, do Prof. Lysandro Mele Pereira da Silva, enviada ao corpo docente da FAUUSP reiterando o que foi deliberado durante a reunião do dia 6 de dezembro de 1955.

65 Conforme documento número 1.552.1 "Cadeira: composição decorativa (v. ano) - Número de aulas teóricas e práticas recomendável para um eficiente desenvolvimento da cadeira a meu cargo”, do Arquivo Documental Lina Bo Bardi, do Instituto Lina Bo e P.M. Bardi. 
Em 1956, a última turma ${ }^{66}$ de alunos de Lina era composta por:

Aderbal Brito Arantes

Aldo Rui Zappelini

Alice Costa

Anésio Bento Cauduro

Antonio Melchor

Araken Martinho

Arnaldo Tonissi

Carol José Hernandez Pirela

Elizabeth Maria Blumberg

Fernando Augusto Senna Arantes

Fernando José Nogueira

Francisco Whitaker Ferreira

Heitor Ferreira de Souza

Ismael Victor de Campos Junior

Jair Peres

João Walter Toscano

José Leite de Carvalho e Silva

Julio R. Katinsky

Luiz Madureira Sewaybricker

Luzia Helena Carlos de Oliveira

Marcio Augusto Schmidt Alves

Mario Alfredo Reginato

Nelson Broto

Paschoal Francisco Viscardi

Richard Henry Perret-Gentil Dubs

Roberto Frioli

Selem Nelsom Bussab

Thyrso Aranha Pereira

Ubirajara Gonsalves Gilioli

Walter Fratini Doles

Wanda de Oliveira Conte Sotto

Zilah Therezinha de Lauro Castrucci

A partir de 1957, as ementas da aula de José Maria da Silva Neves, que assumia integralmente o $3^{\circ}$ e $4^{\circ}$ anos, passava a conter termos como "técnica da construção do móvel" e "industrial design”. Levando em consideração o depoimento de Lúcio Gomes Machado sobre a atuação de José Maria da Silva Neves em banca de Juliano Pereira (Pereira, 2009), é possível que a inclusão de tais termos nas ementas estivesse muito mais relacionada a uma abordagem estilística do que a uma abordagem metodológica, ou mesmo ideológica, do desenho industrial.

66 Conforme documento número 1.556.3 "FAUUSP / Total de havidas e frequentadas de "Composição Decorativa" durante os meses de março, abril e maio", do Arquivo Documental Lina Bo Bardi, do Instituto Lina Bo e P.M. Bardi. 
Mas no Arquivo Documental de Lina Bo Bardi não havia somente cópias das ementas de Composição Decorativa de $1953^{67}$ e $1956^{68}$, as mesmas e mais antigas encontradas no acervo da FAU, talvez referência para as aulas de 1955 e 1956 que preparou; foram encontradas ainda ementas de Composição Decorativa de 1961 e 1962, dadas por José Maria da Silva Neves. Será possível que José Maria da Silva Neves manteve contato com Lina, como que por pedir conselho ou aprovação sobre o conteúdo que iria dar aos estudantes?

\section{De 1956 a 1962}

Com a aprovação do primeiro regulamento ${ }^{69}$, várias disciplinas foram reorganizadas em cadeiras únicas, como "Cálculo Diferencial e Integral”, "Geometria Analítica” e "Matemática Superior e Nomografia" que se tornaram a Cadeira 1, "Cálculo Diferencial e Integral. Geometria Analítica. Nomografia"; ou, Plástica, que teve sua carga de 5 anos reduzida para 3 $\operatorname{anos}\left(\right.$ do $2^{\circ}$ ao $4^{\circ}$ ano) e foi incorporada oficialmente como uma disciplina auxiliar da composição arquitetônica.

Além disso, a FAU se estruturava administrativamente independente da Escola Politécnica com a criação de seu Conselho Técnico e Administrativo e uma Congregação, já que seriam abertos concursos para o provimento de catedráticos das Cadeiras recém criadas. Um desses concursos, o primeiro a se realizar na FAU, em 1956, teve Paulo de Camargo e Almeida, Ernest Robert de Carvalho Mange e Zenon Lotufo concorrendo a vaga de catedrático de Composição de Arquitetura I. Mas a banca composta por Demétrio Ribeiro, Lourival Gomes Machado e Diógenes Rebouças reprovou todos seus concorrentes e, nem mesmo Zenon Lotufo, responsável pela cadeira, foi promovido como esperava ${ }^{70}$, tendo ficado até 1957 como docente da FAU.

Ana Lúcia Cerávolo $\left(2000^{71}\right)$ comenta que Paulo de Camargo e Almeida estudara na ENBA de 1925 a 1929 — sendo contemporâneo de Oscar Niemeyer, Affonso Eduardo Reidy, Abelardo de Souza, Luiz Nunes e Hélio Duarte, entre outros, que participaram da consolidação da arquitetura moderna no Brasil ${ }^{72}$ - e teve a oportunidade de ver de perto o

67 "FAUUSP/ Composição Decorativa/ Prof. Contratado: Antonio Paim Vieira/ Programa proposto para 1953". Documento número 1.550.2, do Arquivo Documental Lina Bo Bardi, do Instituto Lina Bo e P.M. Bardi.

68 "FAUUSP/ Cadeira n. 22 "Composição Decorativa"/ Programa proposto para o ano de 1956". Documento número 1.550.3, do Arquivo Documental Lina Bo Bardi, do Instituto Lina Bo e P.M. Bardi.

69 São Paulo (Estado). Lei 3.233 de 27 de outubro de 1955, que regulamenta a Faculdade de Arquitetura e Urbanismo da Universidade de São Paulo, criada pela Lei n. 104, de 21 de junho de 1948, e dá outras providências.

70 Conforme relatado por Sylvia Ficher, 2005, pág. 292, sobre a vida acadêmica de Zenon Lotufo.

71 CERÁVOLO, 2000.

72 Conforme Cerávolo, s/d. 
único ano da direção de Lucio Costa a frente da Escola, enquanto preparava a documentação para uma viagem de pós-graduação que ganhara por conta da premiação de graduação, por ter sido o melhor aluno da turma. Viajou para Paris em 1931 e lá frequentou a casa de Gertrude Stein e conheceu outros intelectuais como Mies van der Rohe, Walter Gropius, Joseph Luis Sert, apesar de ter passado lá pouco tempo por conta de uma gravidez complicada da esposa e ter retornado para o Brasil. No retorno para o Brasil se filia ao PCB por influência de Luís Carlos Prestes, primo de seu pai, Carlos Ferreira de Almeida.

Para o concurso, Paulo de Camargo e Almeida apresentou a tese "A função social do

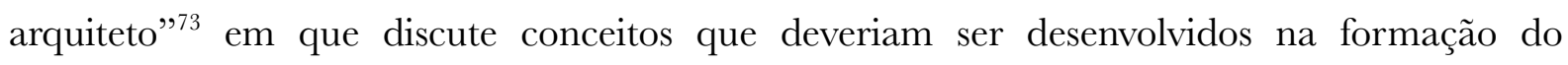
arquiteto.

$\left(1^{\circ}\right)$ a necessidade inadiável da mobilização da terra para os grandes planos urbanísticos de interesse coletivo;

$\left(2^{\circ}\right)$ a necessidade inadiável da planificação integral que, partindo dos Municípios, se irradie pelos Estados e pela Nação;

( $\left.3^{\circ}\right)$ a necessidade inadiável de serem organizados planos coletivos de habitação, programados para a execução imediata e sucessiva, como marco inicial da luta pelo levantamento do nível social do homem;

$\left(4^{\circ}\right)$ a necessidade inadiável de um maior intercâmbio entre o arquiteto e a indústria, para que se consiga ampliar ao máximo a pré-fabricação dos elementos construtivos;

(5) a necessidade inadiável que os arquitetos se orientem no sentido de que todo trabalho profissional deve ter o sentido do interesse coletivo, a fim de conseguirmos o bem estar da sociedade e o consequente aprimoramento do ser humano;

(6ํ) a necessidade inadiável que os arquitetos, orientando o seu trabalho no sentido de dar ao homem condições decentes de vida, propugnem para que o ensino efetivo da arquitetura se fixe em torno dos postulados acima, partindo de uma pesquisa inicial da vida humana e de seus reflexos na sociedade.

Os conceitos (transcritos anteriormente) dialogavam com os postulados corbusianos presentes na essência das disciplinas de composição e urbanismo da FAU e com as teses gerais da arquitetura moderna, como a centralização do planejamento e da promoção de habitação centradas na mão do Estado e a tarefa do arquiteto de se entrosar com a atividade industrial para a produção de componentes construtivos pré-fabricados. Mas foi reprovado no concurso, como já se apontou, junto com os outros concorrentes. Curiosamente, em 1957, fez parte da equipe composta também por João Batista Vilanova Artigas, Carlos Cascaldi e Mário Wagner

$73 \quad$ Almeida, 1956. 
Vieira que ficou em $5^{\circ}$ lugar no concurso para o Plano Piloto de Brasília. Mas em 1960, depois de nomeado diretor executivo do FUNDUSP (Fundo de Construção da Cidade Universidade de São Paulo), teria se recusado a "dar" o projeto do novo edifício da FAUUSP na Cidade Universitária para Artigas, que só o realizou depois que Pedro Paulo de Mello Saraiva e Paulo Mendes da Rocha lhe deram uma "prensa"74. Paulo de Camargo e Almeida, responsável pela criação do mestrado em Industrialização das Construções na EESC-USP, em 1971, e que também chegou a realizar um importante estudo sobre o estado da arte da industrialização da arquitetura $^{75}$ no Brasil, foi alguém com quem a comunidade da FAU escolheu não dialogar ${ }^{76}$.

De volta às cadeiras de composição, as ementas de Pequenas Composições I e II e de Grandes Composições I (Cadeira 16, 17 e 18, respectivamente) apontavam conceitos que seriam desenvolvidos junto aos exercícios de projeto, entre os quais "arte, indústria e máquina”, “os sistemas construtivos, sistemas elementares, estrutura e equipamento, esqueleto e membranas, aço, concreto, madeira, pré-fabricação, normalização"e "a economia, a simplicidade da máquina, a lição da máquina". Mas o que esses termos significavam para esses docentes uma vez que esses termos não estavam presentes em sua prática projetual?

Os exercícios propostos pelos docentes, respectivamente Zenon Lotufo, Abelardo de Souza e Oswaldo Corrêa Gonçalves, não se aproximavam das questões de produção da arquitetura. Muito possivelmente, não passavam de termos estilísticos sempre empregados pelos arquitetos formados pelas ideias do movimento moderno.

\section{PRIMEIRO ANO}

Em 1962, ano da Reforma Curricular, a Cadeira 16 foi usada para a implantação do Desenho Industrial para o $1^{\circ}$ ano $^{77}$. Possivelmente, as atividades de Pequenas Composições I se mantiveram, enquanto Desenho Arquitetônico, disciplina em que se trabalhava conceitos de desenho técnico aplicado ao projeto, foi transformado em Desenho Industrial I, ministrado por Hélio de Queirós Duarte assistido por Marlene Picarelli e Lúcio Grinover.

\footnotetext{
74 Saraiva, 2009.

75 ALMEIDA, 1971.

76 Depois desse episódio não foram localizados documentos ou relatos de atividade de Paulo de Camargo e Almeida com a comunidade da FAUUSP. Para uma leitura sobre a trajetória do arquiteto, ver CERÁVOLO, 2000.

$77 \quad$ FAUUSP, 1963.
} 


\section{Grade curricular do período 1956-1962}

\begin{tabular}{|c|c|c|c|}
\hline \multirow[t]{5}{*}{$1^{\circ}$ ano } & $\begin{array}{l}\text { Cadeira } 1 . \\
\text { Cálculo diferencial e } \\
\text { integral. Geometria } \\
\text { analítica. Nomografia }\end{array}$ & $\begin{array}{l}1956 \\
1957-62\end{array}$ & $\begin{array}{l}\text { docente não indicado na ementa } \\
\text { José Octávio Monteiro de Camargo }\end{array}$ \\
\hline & $\begin{array}{l}\text { Cadeira } 2 . \\
\text { Geometria descritiva e } \\
\text { aplicações }\end{array}$ & $\begin{array}{l}1956-57 \\
1958-62\end{array}$ & $\begin{array}{l}\text { docente não indicado na ementa } \\
\text { Pedro Moacyr do Amaral Cruz }\end{array}$ \\
\hline & $\begin{array}{l}\text { Cadeira } 13 . \\
\text { Arquitetura analítica }\end{array}$ & $\begin{array}{l}1956-60 \\
1961 \\
1962\end{array}$ & $\begin{array}{l}\text { Enoch de Rocha Lima } \\
\text { cadeira não indicada no programa de disciplinas } \\
\text { de } 1961 \\
\text { Joaquim Bezerra da Silva }\end{array}$ \\
\hline & $\begin{array}{l}\text { Cadeira } 16 . \\
\text { Composição de arquitetura. } \\
\text { Pequenas composições I. } \\
\text { Desenho arquitetônico }\end{array}$ & $\begin{array}{l}1956-57 \\
1958-62 \\
1961-62 \\
1961-62\end{array}$ & $\begin{array}{l}\text { Zenon Lotufo } \\
\text { Hélio de Queirós Duarte } \\
\text { Marlene Picarelli }^{\mathrm{n}} \\
\text { Lúcio Grinover }\end{array}$ \\
\hline & $\begin{array}{l}\text { Cadeira } 21 . \\
\text { Desenho artístico }\end{array}$ & $1956-62$ & Ernest Robert de Carvalho Mange \\
\hline \multirow[t]{7}{*}{$2^{\circ}$ ano } & $\begin{array}{l}\text { Cadeira } 1 . \\
\text { Cálculo diferencial e } \\
\text { integral. Geometria } \\
\text { analítica }\end{array}$ & $\begin{array}{l}1956 \\
1957-62\end{array}$ & $\begin{array}{l}\text { docente não indicado na ementa } \\
\text { José Octávio Monteiro de Camargo }\end{array}$ \\
\hline & $\begin{array}{l}\text { Cadeira } 3 . \\
\text { Mecânica racional }\end{array}$ & $\begin{array}{l}1956-57 \\
1957-62\end{array}$ & $\begin{array}{l}\text { docente não indicado na ementa } \\
\text { João Augusto Breves Filho }\end{array}$ \\
\hline & $\begin{array}{l}\text { Cadeira } 5 . \\
\text { Materiais de construção }\end{array}$ & $\begin{array}{l}1956-57 \\
1958-62 \\
1958-62\end{array}$ & $\begin{array}{l}\text { cadeira não indicada no programa de disciplinas } \\
\text { de } 1956 \text { e } 1957 \\
\text { José de Oliveira Escorel } \\
\text { Ariosto Mila }\end{array}$ \\
\hline & $\begin{array}{l}\text { Cadeira } 11 . \\
\text { Topografia. Elementos de } \\
\text { astronomia de posição }\end{array}$ & $\begin{array}{l}1956 \\
1957 \\
1958-62\end{array}$ & $\begin{array}{l}\text { docente não indicado na ementa } \\
\text { Henrique Jorge Guedes } \\
\text { Paulo Ferraz de Mesquita }\end{array}$ \\
\hline & $\begin{array}{l}\text { Cadeira } 14 . \\
\text { Teoria da arquitetura }\end{array}$ & $\begin{array}{l}1956 \\
1957 \\
1962\end{array}$ & $\begin{array}{l}\text { docente não indicado na ementa } \\
\text { Eduardo Corona } \\
\text { Carlos Lemos }\end{array}$ \\
\hline & $\begin{array}{l}\text { Cadeira } 16 . \\
\text { Composição de arquitetura. } \\
\text { Pequenas composições I. } \\
\text { Plástica I }\end{array}$ & $\begin{array}{l}1956-57 \\
1958-62 \\
1958-62 \\
1961-62 \\
1961-62 \\
1961-62\end{array}$ & $\begin{array}{l}\text { Zenon Lotufo } \\
\text { Hélio de Queirós Duarte } \\
\text { Plínio Croce }^{\mathrm{h}} \\
\text { José Roberto Goulart Tibau } \\
\text { Marlene Picarelli } \\
\text { Lúcio Grinover }\end{array}$ \\
\hline & $\begin{array}{l}\text { Cadeira } 21 . \\
\text { Desenho artístico }\end{array}$ & $\begin{array}{l}1956 \\
1957-62 \\
1962 \\
1962 \\
1960 ? \\
1960 ?\end{array}$ & $\begin{array}{l}\text { docente não indicado na ementa } \\
\text { Ernest Robert de Carvalho Mange } \\
\text { João Baptista Alves Xavier } \\
\text { Cândido Malta Campos Filho } \\
\text { Élide Monzéglio } \\
\text { Vera Helena do Amaral }^{\mathrm{h}}\end{array}$ \\
\hline
\end{tabular}




\section{SEGUNDO ANO}

Em "Materiais de Construção", 2 ano, transformada na Cadeira 5, a abordagem dos materiais de construção do ponto vista tecnológico de suas propriedades, produção e composição foi reduzida a uma parte da disciplina, que passou também a abordar os materiais do seu ponto de vista funcional na construção a partir de seu uso na vedação, na cobertura, nos revestimentos ou nas instalações prediais de água, gás, energia e ar condicionado. Em 1962, a ementa já apresenta um programa bastante focado na função arquitetônica dos materiais, tendo sido excluído todo o texto sobre o estudo tecnológico das propriedades dos materiais, característica marcante do ensino politécnico que ia sendo retirado do curso para arquitetos, conhecimentos talvez indispensáveis para o desenho industrial de componentes.

No $2^{\circ}$ ano da Cadeira 16 era ministrada a segunda parte de Pequenas Composições I e Plástica I. Em Pequenas Composições I dava-se continuidade às séries de exercícios projetuais iniciados no $1^{\circ}$ ano. Hélio Duarte, docente a partir de 1958, propunha à cada uma das turmas, tanto $1^{\circ}$ como $2^{\circ}$ anos, que o melhor projeto elaborado em Pequenas Composições fosse executado em local previamente fixado, cabendo ao autor a direção dos trabalhos técnicos para a execução, em que participaria toda a turma.

Em Desenho Artístico, Cadeira 21, até 1961 eram desenvolvidos estudos das técnicas de aplicação de cor com aquarela, guache e pastel além de continuar a representação das concepções arquitetônicas elaboradas na Cadeira de Pequenas Composições, incluídos agora exercícios referentes às atividades desenvolvidas também nas cadeiras de "Arquitetura Analítica" e "Teoria de Arquitetura". O repertório estilístico das outras cadeiras servia como base para os exercícios práticos de Desenho Artístico. Em 1962, ano da Reforma, a Cadeira 21 foi usada para que Ernest Mange ministrasse as atividades de Desenho Industrial II para o $2^{\circ}$ ano, assistido por João Baptista Alves Xavier e Cândido Malta Campos Filho.

\section{TERCEIRO ANO}

Outras disciplinas que se fundiram numa só cadeira foram "Construções Civis" e "Elementos de Mecânica dos Solos. Fundações" do $3^{\circ}$ ano da primeira fase curricular, transformadas na Cadeira 9, "Técnica das Construções. Organização dos Trabalhos e Prática Profissional. Higiene dos Edifícios. Noções de Mecânica dos Solos. Fundações”, cujo conteúdo foi estendido e ministrados tanto para o $3^{\circ}$ e como para o $4^{\circ}$ ano da graduação. A responsabilidade pela Cadeira era compartilhada entre Ariosto Mila e Victor Froilano Bachmann de Mello, este último responsável por ministrar para o $3^{\circ}$ ano o conteúdo de 
Noções de Mecânica dos Solos e Fundações. O conteúdo ministrado por Ariosto Mila, "Técnica das Construções. Organização dos Trabalhos e Prática Profissional. Higiene dos Edifícios" foi distribuído para o $3^{\circ}$ e $4^{\circ}$ anos de maneira variada ao longo do tempo. Nessa disciplina estudavam-se não somente os processos construtivos, mas também a gestão do canteiro de obra, do projeto à construção.

"Técnicas das construções" constituía um repertório de sistemas, materiais e processos construtivos disponíveis à época que era apresentado aos estudantes sobre as fundações, estruturas, instalações prediais entre outros. Em "Prática Profissional" eram apresentadas aos estudantes principalmente as questões relativas a documentação legal e trâmites em órgãos públicos para aprovação do projeto, além das modalidades e setores de atuação e a regulamentação da profissão de arquiteto no Brasil. Em "Higiene dos Edifícios" era apresentado um repertório de dispositivos e instalações prediais para arejamento, tratamento acústico, iluminação natural e artificial dos ambientes, fornecimento de água e energia elétrica e remoção de lixo e esgotamento sanitário.

Para o $4^{\circ}$ ano, ao menos em 1959 e 1960, eram previstas aulas práticas que se realizariam durante 4 dias na Escola SENAI do Tatuapé ${ }^{78}$, de construção civil, complementando as aulas teóricas. Nessas 4 aulas práticas os estudantes deveriam executar de alvenaria de blocos, alvenaria de pedra, o assentamento de azulejos e o assentamento de mosaico (sem indicar qual a técnica).

Em 1958, na Cadeira 17, “Composição de Arquitetura - Pequenas Composições II. Plástica II", os exercícios propunham o entrosamento com as cadeiras de Materiais de Construção e de Composição Decorativa"; o projeto deveria contemplar detalhamento construtivo, estudo minucioso dos materiais de construção e o equipamento mobiliário interno. Docente, assistentes e estudantes, promoveram então uma exposição permanente de materiais construtivos, elaborada em conjunto com a cadeira Materiais de Construção. Seria ainda alguma influência de Lina na elaboração de uma "materioteca", a exemplo do que tentou para Composição Decorativa?

78 À época, a escola de construção civil do SENAI funcionava à Rua São Jorge, 634, Tatuapé, cujo projeto arquitetônico é de autoria de Lúcio Grinover, em 1958. Durante os anos 1970 foi transferida para a Rua Teixeira de Melo, com o nome de Escola SENAI "Orlando Laviero Ferraiuolo". FONTE: http://construcaocivil.sp.senai.br/institucional/1578/0/historico. 


\section{Grade curricular do período 1956-1962}

\begin{tabular}{|c|c|c|c|}
\hline \multirow[t]{5}{*}{$3^{\circ}$ ano } & $\begin{array}{l}\text { Cadeira } 4 . \\
\text { Física geral e aplicada }\end{array}$ & $\begin{array}{l}1956 \\
1957-62 \\
1959-62\end{array}$ & $\begin{array}{l}\text { docente não indicado na ementa } \\
\text { Luiz Cintra do Prado } \\
\text { Léo Nishikawa }^{\text {h }}\end{array}$ \\
\hline & $\begin{array}{l}\text { Cadeira } 6 . \\
\text { Resistência dos } \\
\text { materiais e estabilidade } \\
\text { das construções }\end{array}$ & $\begin{array}{l}1956 \\
1957-62 \\
1956-57\end{array}$ & $\begin{array}{l}\text { docente não indicado na ementa } \\
\text { Telêmaco van Langendonck } \\
\text { Augusto Carlos de Vasconcelos }\end{array}$ \\
\hline & $\begin{array}{l}\text { Cadeira } 9 . \\
\text { Técnica das construções. } \\
\text { Organização dos trabalhos e } \\
\text { prática profissional. Higiene dos } \\
\text { edificios. Noções de mecânica dos } \\
\text { solos. Fundações }\end{array}$ & $\begin{array}{l}1956 \\
1957-62 \\
1956-57 \\
1956-62\end{array}$ & $\begin{array}{l}\text { docente não indicado na ementa } \\
\text { Ariosto Mila } \\
\text { Joaquim Guedes Sobrinho } \\
\text { Victor Froilano Bachmann de Mello }\end{array}$ \\
\hline & $\begin{array}{l}\text { Cadeira } 17 . \\
\text { Composição de arquitetu- } \\
\text { ra. Pequenas composições } \\
\text { II. Plástica II }\end{array}$ & $\begin{array}{l}1956 \\
1957-62 \\
1961 ? \\
1956-62\end{array}$ & $\begin{array}{l}\text { docente não indicado na ementa } \\
\text { Abelardo Riedy de Souza } \\
\text { Miranda Maria Martinelli Magnoli } \\
\text { Jon Maitrejean }\end{array}$ \\
\hline & $\begin{array}{l}\text { Cadeira } 22 . \\
\text { Composição decorativa }\end{array}$ & $\begin{array}{l}1957-62 \\
1961 ? \\
1956-62\end{array}$ & $\begin{array}{l}\text { José Maria Silva Neves } \\
\text { Abrahão Velvu Sanovicz } \\
\text { Luiz Gastão de Castro Lima }\end{array}$ \\
\hline \multirow[t]{7}{*}{$4^{\circ}$ ano } & $\begin{array}{l}\text { Cadeira } 7 . \\
\text { Estruturas correntes de } \\
\text { madeira, metálicas e de } \\
\text { concreto simples e armado }\end{array}$ & $\begin{array}{l}1956 \\
1957-62\end{array}$ & $\begin{array}{l}\text { docente não indicado na ementa } \\
\text { José Carlos de Figueiredo Ferraz }\end{array}$ \\
\hline & $\begin{array}{l}\text { Cadeira } 8 . \\
\text { Grandes estruturas }\end{array}$ & $\begin{array}{l}1956 \\
1957-62\end{array}$ & $\begin{array}{l}\text { docente não indicado na ementa } \\
\text { Pedro Bento José Gravina }\end{array}$ \\
\hline & $\begin{array}{l}\text { Cadeira } 9 . \\
\text { Técnica das construções. } \\
\text { Organização dos trabalhos } \\
\text { e prática profissional. } \\
\text { Higiene dos edifícios }\end{array}$ & $\begin{array}{l}1956 \\
1957-62\end{array}$ & $\begin{array}{l}\text { docente não indicado na ementa } \\
\text { Ariosto Mila }\end{array}$ \\
\hline & $\begin{array}{l}\text { Cadeira } 10 . \\
\text { Hidráulica: hidráulica } \\
\text { urbana e saneamento }\end{array}$ & $\begin{array}{l}1956 \\
1957 \\
1958-62\end{array}$ & $\begin{array}{l}\text { docente não indicado na ementa } \\
\text { Lysandro Mele Pereira da Silva } \\
\text { Lucas Nogueira Garcez }\end{array}$ \\
\hline & $\begin{array}{l}\text { Cadeira } 12 . \\
\text { Noções de economia } \\
\text { política. Estatística aplicada. } \\
\text { Organização administrativa. } \\
\text { Legislação e contabilidade } \\
\text { específica I }\end{array}$ & $\begin{array}{l}1956 \\
1957-60 \\
1961 \\
1962\end{array}$ & $\begin{array}{l}\text { docente não indicado na ementa } \\
\text { Mário Wagner Vieira da Cunha } \\
\text { cadeira não indicada no programa de disciplinas } \\
\text { Juarez Rubens Brandão Lopes }{ }^{\mathrm{i}}\end{array}$ \\
\hline & $\begin{array}{l}\text { Cadeira } 18 . \\
\text { Composição de arquitetura. } \\
\text { Grandes composições I. } \\
\text { Plástica III }\end{array}$ & $\begin{array}{l}1956 \\
1957 \\
1958-62\end{array}$ & $\begin{array}{l}\text { Oswaldo Corrêa Gonçalves } \\
\text { Caetano Fraccarolli }^{\mathrm{n}} \\
\text { Hélio de Queirós Duarte } \\
\text { Roberto de Cerqueira César } \\
\text { Carlos Barjas Millan } \\
\text { Luiz Roberto Carvalho Franco } \\
\text { Dario Imparato }\end{array}$ \\
\hline & $\begin{array}{l}\text { Cadeira } 18 . \\
\text { Composição decorativa }\end{array}$ & $\begin{array}{l}1956 \\
1957-61\end{array}$ & $\begin{array}{l}\text { docente não indicado na ementa } \\
\text { José Maria Silva Neves }\end{array}$ \\
\hline
\end{tabular}


Com o passar dos anos, Abelardo foi amadurecendo a ferramenta PLANEJAMENTO por meio da abordagem de conjuntos de edifícios ao articulá-los com a rua e com a situação urbanística existente, e aproximava a atividade didática das atividades externas do CPEU (Centro de Pesquisa e Estudos Urbanísticos). Em 1959, 1960 e 1961, os exercício abordam projetos urbanísticos para cidades do interior paulista, como Socorro e Leme, para as quais o CPEU já havia elaborado Planos Diretores.

Em 1962, Aberlardo e assistentes propuseram o projeto de uma "unidade de habitação para 500 operários de uma fábrica situada nos arredores de São Paulo", dialogando com a abordagem que o grande capital faria da necessidade de habitação, para operários. Mas a ementa de Plástica II para o $3^{\circ}$ ano, ministrada também por Abelardo e assistentes, é bastante genérica, indicando exercícios de expressão gráfica em superfícies planas e exercícios, em oficina, sobre o volume e o espaço.

Como curiosidade, relatamos rapidamente o depoimento de Jon Maitrejean ${ }^{79}$ : em 1960 teria elaborado um exercício para que os estudantes não só indicassem com mais detalhe os materiais construtivos, mas que criassem novos sistemas construtivos para serem montados no canteiro. Conforme o depoimento, os estudantes não entenderam exatamente o que deveria ser elaborado e o exercício não foi além dos mesmos projetos de arquitetura programática.

E em 1962, e somente para o $3^{\circ}$ ano, a ementa de Composição Decorativa vai trazer "conceito e prática do desenho industrial, generalidades, apanhado histórico sobre os problemas da arquitetura e da indústria". Neste ano é proposto aos estudantes o exercício relativo a Desenho Industrial III - o re-estudo de um jogo de xadrez e o projeto de um isqueiro a partir de um mecanismo existente dado ${ }^{80}$ — por José Maria da Silva Neves, auxiliado por Abrahão Sanovics e Luiz Gastão de Castro Lima.

\section{QUARTO ANO}

Em 1958, na Cadeira 18 "Composição de Arquitetura - Grandes Composições I. Plástica III”, Roberto de Cerqueira César, então responsável pela cadeira, propunha para as aulas téoricas um diálogo com os conhecimentos estudados nas cadeiras técnicas, sua aplicação e influência na arquitetura. Essa era uma prática característica da reforma de 1962 e que já vinha sendo ensaiada ao menos nas cadeiras de composição de desde 1957, conforme o relatório de Carlos Millan ${ }^{81}$. Nas aulas de Roberto seriam revisados os elementos técnicos,

79 Entrevista concedida em 12 de setembro de 2015.

80 FAUUSP, 1963.

81 MILLAN, 1963. 
funcionais e plásticos da arquitetura. Entre esses elementos, somente o item "Vedações" possui elencadas opções pré-fabricadas e moduladas. Não havia opções pré-fabricadas ou industrializadas para estruturas, fundações, instalações prediais, etc. Roberto Cerqueira César compreendia que toda a construção pode ser industrializada? Ou entendia pré-fabricação como elementos de vedação?

Em 1959 e 1960, juntamente com a Cadeira de Grandes Composições II, do $5^{\circ}$ ano, o $4^{\circ}$ ano trabalharia no projeto de um conjunto urbanos de edifícios para a cidade de Águas da Prata, para a qual cada equipe deveria elaborar um plano urbanístico adequado a partir de uma pesquisa realizada na base de dados do CPEU, que havia há pouco elaborado o Plano Diretor da mesma cidade.

Em 1961, o tema da “Grande Composição I” era a assistência hospitalar à uma comunidade, em que as equipes deveriam propor um conjunto de edificações necessárias ao atendimento de saúde em uma cidade (não especificada) e cada edifício seria detalhado individualmente.

A ementa de "Plástica III", melhor discriminada a partir de 1959, sugere que desde então eram trabalhados projetos de mobiliário urbano (como locais de recreio, elementos de jardim e playground, etc) relacionados ao plano urbanístico e ao conjunto arquitetônico desenvolvido em Composição. Além disso, era em Plástica que os estudantes elaboravam o projeto da exposição dos trabalhos desenvolvidos, além da "composição gráfico do volume" na eventualidade de uma publicação em papel.

Mas a ementa de 1961 sugere que em "Plástica" foram não só desenvolvidas maquetes para o projeto de arquitetura, mas também foram desenvolvidos "trabalhos no campo do Desenho Industrial em colaboração com a Cadeira de Produção Industrial da Escola Politécnica" ministrada pelo Prof. Dr. Ruy Aguiar da Silva Leme, muito provavelmente o projeto para o mobiliário dos equipamentos de saúde.

As cadeiras de Composição já trabalhavam via de regra em duas frente: em composição de arquitetura e em Plástica, auxiliando a primeira. Em 1962, com a implantação da Reforma, é possível que o conteúdo de DI do $4^{\circ}$ ano tenha sido dado nas aulas de Plástica III, sob supervisão dos professores assistentes. A ementa de Grandes Composições I é bastante genérica, mas sugere que foi proposto para os estudantes o desenvolvimento do projeto de um complexo arquitetônico que dialogava com a realidade urbana e que houve a tentativa de integração com outras cadeiras de tecnologia e de história para melhor orientar a atividade dos alunos. 


\section{Grade curricular do período 1956-1962}

\begin{tabular}{|c|c|c|c|}
\hline \multirow[t]{5}{*}{$5^{\circ}$ ano } & $\begin{array}{l}\text { Cadeira } 15 . \\
\text { História da arte. Estética }\end{array}$ & $\begin{array}{l}1956 \\
1957-62\end{array}$ & $\begin{array}{l}\text { docente não indicado na ementa } \\
\text { Flávio Motta }\end{array}$ \\
\hline & $\begin{array}{l}\text { Cadeira } 19 . \\
\text { Composição de } \\
\text { arquitetura. Grandes } \\
\text { composições II }\end{array}$ & $\begin{array}{l}1956 \\
1957 \\
1955-60 \\
1956 \\
1961-62\end{array}$ & $\begin{array}{l}\text { ementa não indicada no programa de disciplinas } \\
\text { Hélio de Queirós Duarte }{ }^{\mathrm{n}} \\
\text { Rino Levi }^{\mathrm{k}} \\
\text { Roberto Cerqueira César }^{\mathrm{k}} \\
\text { João Baptista Vilanova Artigas }\end{array}$ \\
\hline & $\begin{array}{l}\text { Cadeira } 19 . \\
\text { Arquitetura no Brasil }\end{array}$ & $\begin{array}{l}1956-62 \\
1957\end{array}$ & $\begin{array}{l}\text { Eduardo Kneese de Mello } \\
\text { Nestor Goulart Reis Filho }{ }^{n}\end{array}$ \\
\hline & $\begin{array}{l}\text { Cadeira } 23 . \\
\text { Urbanismo }\end{array}$ & $\begin{array}{l}1956 \\
1957-61 \\
1962\end{array}$ & $\begin{array}{l}\text { docente não indicado na ementa } \\
\text { Luiz Inácio de Anhaia Melo } \\
\text { Lauro Bastos Birkholz }\end{array}$ \\
\hline & $\begin{array}{l}\text { Cadeira } 28 . \\
\text { Arquitetura paisagística }\end{array}$ & $\begin{array}{l}1956 \\
1957-62 \\
19 ? ?\end{array}$ & $\begin{array}{l}\text { docente não indicado na ementa } \\
\text { Roberto Coelho Cardozo } \\
\text { Miranda Martinelli Magnoli }^{\text {n }}\end{array}$ \\
\hline & Composição decorativa $^{n}$ & 1956 & Lina Bo Bardi ${ }^{1}$ \\
\hline
\end{tabular}


Em Plástica III, engana-se quem lê a ementa de 1962, que indica o desenvolvimento de exercício ligado "ao campo do Desenho Industrial”; "o estudo e projeto de implementos e equipamentos do edifício, industrializados e industrializáveis" a que se refere a ementa não diz respeito a um exercício de desenho de componentes da edificação, completando o mote da ementa de Grandes Composições I, sobre o desenvolvimento de um conjunto arquitetônico. Seus exercícios de desenho industrial resultam em outra coisa que não arquitetura industrializada. Tratava-se, dentro de uma proposta ainda que legítima, de "propor solução para o preparo do café doméstico brasileiro"ou o "redesenho do simples bule tradicional até os sistemas mais elaborados de funcionamento a vapor ou pressão" ${ }^{\text {. }}$.

\section{QUINTO ANO}

No $5^{\circ}$ ano, a leitura das ementas de Composição mostra como Rino Levi — à frente da cadeira ao menos desde $1955^{83}$ até 1960 - mudava, ano a ano, os exercícios desenvolvidos com os estudantes, possivelmente testando os resultados que mais se aproximavam com o que entendia ser necessário ensinar sobre Grandes Composições.

Em 1955, o arquiteto propõe aos estudantes ensaios urbanísticos sobre estacionamentos de veículos para o centro de São Paulo e centro da Penha, sobre os quais foi publicado até um artigo em Habitat (fev. 1956, n. 27, p. 47). Em 1956, propôs aos estudantes tema livre, mas real e atual e que contemplasse as " 3 funções da vida humana: habitação, trabalho e recreação" numa clara referência à carta de Atenas e Le Corbusier; eram apontados alguns exemplos do que os estudantes poderiam desenvolver - como "unidade de vizinhança, centro de bairro, centro comercial, conjunto industrial com centro residencial operário, conjunto esportivo, problemas de saúde, de ensino, de abastecimento, de estacionamento etc de uma comunidade" - a partir de uma primeira etapa em que toda a turma elaboraria um plano geral para o conjunto dos edifícios (sem indicar em qual cidade) "dando oportunidade para o estudo dos problemas da circulação", noutra referência à Carta de Atenas e à Le Corbusier, e cada edifício seria detalhado individualmente.

Os projetos deveriam considerar "fatores técnicos e científicos" tais como "ambiente físico, estrutura, materiais, equipamento, técnica construtiva, racionalização, normalização, padronização, industrialização, pré-fabricação". Possivelmente, os fatores técnicos e científicos destacados não passassem dos mesmos chavões sempre usados pelos profissionais do

82 FAUUSP, 1963.

83 Conforme artigo da Revista Habitat (n. 27, p. 47, fev. 1956) e o Programa de Disciplinas de 1957 até 1960. 
meio.

A partir de 1957 não há mais referências à Carta de Atenas e a Le Corbusier. Se até 1956 a turma trabalha junta na elaboração de um plano geral urbano de serviços e depois detalha individualmente cada edificio, a partir de 1957, as equipes e cada estudante passam a estudar um só tema de rede de serviço urbano - se educação, se saúde, se transporte, se habitação, etc - e elabora só esse tema para uma cidade específica, sempre em acordo com seu Plano Diretor, via de regra desenvolvido pelo CPEU. Foi assim em 1958 para Taubaté e em 1959 e 1960 para Águas da Prata, cujos Planos Diretores já haviam sido desenvolvido pelo CPEU.

A Revista Habitat aponta como

"Rino Levi é um dos iniciadores da renovação arquitetônica no pais — sua idoneidade é reconhecida, seus esforços para uma boa adequação profissional, para a concepção racional e, enfim, para uma compreensão urbanística ligada à arquitetura" e "julga, efetivamente, que não se pode mais cuidar da composição arquitetônica isolada". (Revista Habitat, n. 27, p. 47, fev. 1956).

De fato, percebe-se como Rino Levi trabalha as questões urbanísticas nos exercícios de arquitetura, não mais entendida como fato isolado mas dentro de um contexto urbano e, assim, uma das pautas da agenda da arquitetura moderna era incluída no ensino de arquitetura.

É interessante ainda notar como a palavra "problema" era escrita, não somente nesta ementa, associada às ideias de habitação, saúde, transporte, educação, abastecimento, etc. Por que esses temas seriam um problema? Quais são os problemas associados a esses temas, para além de uma questão tão genérica? E mais: como se resolvem esses problemas? Queremos, na verdade, apontar como o projeto de um edifício (mesmo que um exercício didático) que partia de um "problema" poderia facilmente ser considerado, ou confundido, com a solução daquele problema.

Em 1961 e 1962, a Cadeira 19 Grandes Composições II está sob responsabilidade de João Batista Vilanova Artigas mas, as ementas ainda são idênticas às utilizadas por Rino Levi em 1958 e 1959. Apesar de ter participado ativamente da implantação da reforma curricular (FAGGIN, 1987.), Artigas não participa neste ano de alguma disciplina impactada pela reforma. 


\section{Depois da reforma de 1962}

Em janeiro de 1962, Carlos Millan, Jon Maitrejean, Giancarlo Gasperini e Lúcio Grinover formaram uma comissão para estudar o Ateliêr por ocasião de uma reforma no ensino que deveria viger a partir de $1962^{84}$. A comissão pretendia a implantação do que Lúcio Grinover chamou de "universidade de projeto", conhecimentos sobre o desenho dos objetos do interior da edificação, a comunicação visual, a arquitetura, o paisagismo e o planejamento. A proposta da comissão, relatada no texto de Carlos Barjas Millan, entendia o Urbanismo como a atividade maior (pela leitura do relatório, a princípio) que englobava as outras escalas de projeto: a arquitetura, o paisagismo e o desenho industrial, e daí a necessidade de um trabalho integrado em ateliê, que funcionaria como um departamento auto-suficiente, paralelo às cadeiras técnico-científicas e as de história e cultura. Didaticamente, a proposta seria desenvolvida em equipes verticais, compostas de 4 estudantes (do $2^{\circ}$ ao $5^{\circ}$ ano), cujo coordenador do projeto seria o estudante do $5^{\circ}$ ano, a quem também caberia o trabalho de urbanismo. "Horizontalmente", cada estudante desenvolveria individualmente um trabalho tirado dos trabalhos verticais do ano anterior, em que seriam mobilizadas as cadeiras seriadas nos respectivos anos.

No entanto, foi implantada a proposta de João Batista Vilanova Artigas - entre outros motivos, por seu carisma profissional (Faggin, 1993) - que estabeleceu as várias disciplinas de projeto isoladas em suas sequências (a sequência de projeto de arquitetura, sequência de desenho industrial, sequência de comunicação visual, sequência de planejamento) até o final dos anos 1960. Não à toa, o "Relatório das Atividade de 1962"86 esclarecia que a reestruturação curricular foi orientada no sentido de despertar o interesse por outros ramos da atividade profissional, e não só formar um profissional capaz de responder às solicitações do progresso industrial e às necessidades sociais, conforme já demandavam os estudantes ${ }^{87}$.

\footnotetext{
84 A Portaria n. 9, de 22 de dezembro de 1961, determinava o novo currículo da FAU que deveria viger a partir de 1962.

85 Conforme depoimento para Pereira (2009) e em entrevista concedida para esta mestranda em 18 de setembro de 2015.

$86 \quad$ FAUUSP, 1963 (c).

87 GFAU, 1963.
} 


\section{Grade curricular pós-1962}

\begin{tabular}{|c|c|c|c|}
\hline \multirow[t]{6}{*}{$1^{\circ}$ ano } & $\begin{array}{l}\text { Cadeira } 1 . \\
\text { Cálculo diferencial e } \\
\text { integral. Geometria } \\
\text { analítica }\end{array}$ & $1963-67$ & Domingos Pizaneli \\
\hline & $\begin{array}{l}\text { Cadeira } 2 . \\
\text { Geometria descritiva e } \\
\text { aplicações }\end{array}$ & $1963-67$ & Pedro Moacyr do Amaral Cruz \\
\hline & $\begin{array}{l}\text { Cadeira 12. Disciplina } 121 \\
\text { Comunicação visual }\end{array}$ & $1963-67$ & Ernest Robert de Carvalho Mange \\
\hline & $\begin{array}{l}\text { Disciplina autônoma } 131 . \\
\text { Desenho industrial I }\end{array}$ & 1966 & João Carlos Cauduro \\
\hline & $\begin{array}{l}\text { Cadeira } 14 . \\
\left.\text { Projeto I ( } 1^{\text {a }} \text { parte }\right)\end{array}$ & $\begin{array}{l}1963-1967 \\
1967 \\
1967\end{array}$ & $\begin{array}{l}\text { Hélio de Queirós Duarte } \\
\text { Roberto Goulart Tibau } \\
\text { Cândido Malta Campos Filho }\end{array}$ \\
\hline & $\begin{array}{l}\text { Cadeira } 20 . \\
\text { História da arte. Estética }\end{array}$ & $\begin{array}{l}1963-1967 \\
1963-1967\end{array}$ & $\begin{array}{l}\text { Flávio Motta } \\
\text { Sérgio Ferro }\end{array}$ \\
\hline \multirow[t]{6}{*}{$2^{\circ}$ ano } & $\begin{array}{l}\text { Cadeira } 3 . \\
\text { Mecânica }\end{array}$ & 1963-1967 & João Augusto Breves Filho \\
\hline & $\begin{array}{l}\text { Cadeira } 4 . \\
\text { Topografia. Elementos de } \\
\text { astronomia e posição }\end{array}$ & $1963-67$ & Paulo Ferraz de Mesquita \\
\hline & $\begin{array}{l}\text { Disciplina autônoma } 122 . \\
\text { Comunicação visual II }\end{array}$ & 1966 & Renina Katz Pedreira \\
\hline & $\begin{array}{l}\text { Disciplina autônoma } 132 . \\
\text { Desenho industrial II }\end{array}$ & $\begin{array}{l}1966 \\
1967 \\
1967\end{array}$ & $\begin{array}{l}\text { Lúcio Grinover } \\
\text { Marlene Picarelli } \\
\text { Manoel Kosciuszko da Silva Corrêa }\end{array}$ \\
\hline & $\begin{array}{l}\text { Cadeira } 14 . \\
\left.\text { Projeto I ( } 2^{\text {a }} \text { parte }\right)\end{array}$ & 1963-1967 & Hélio de Queirós Duarte \\
\hline & $\begin{array}{l}\text { Cadeira } 21 . \\
\text { História da arquitetura I }\end{array}$ & $1963-67$ & Joaquim Bezerra da Silva \\
\hline
\end{tabular}




\section{Grade curricular pós-1962}

\begin{tabular}{|c|c|c|c|}
\hline \multirow[t]{8}{*}{$3^{\circ}$ ano } & $\begin{array}{l}\text { Cadeira } 5 . \\
\text { Física geral e aplicada } \\
\left(1^{\mathrm{a}} \text { e } 2^{\mathrm{a}} \text { partes }\right)\end{array}$ & $\begin{array}{l}1963-66 \\
1967\end{array}$ & $\begin{array}{l}\text { Luiz Cintra Prado } \\
\text { Paulus Aulus Pompéia }\end{array}$ \\
\hline & $\begin{array}{l}\text { Cadeira } 6 . \\
\text { Construção I }\end{array}$ & $1963-66$ & Ariosto Mila \\
\hline & $\begin{array}{l}\text { Cadeira } 7 . \\
\text { Resistência dos materiais } \\
\text { e estabilidade das } \\
\text { construções }\end{array}$ & $1963-67$ & Telêmaco van Langendonck \\
\hline & $\begin{array}{l}\text { Disciplina autônoma } 123 . \\
\text { Comunicação visual III }\end{array}$ & 1966 & João Baptista Alves Xavier \\
\hline & $\begin{array}{l}\text { Cadeira } 13 . \\
\text { Desenho industrial III }\end{array}$ & $\begin{array}{l}1963-67 \\
1967 \\
1965 \\
1965-67\end{array}$ & $\begin{array}{l}\text { José Maria Silva Neves } \\
\text { Lúcio Grinover } \\
\text { Luiz Gastão de Castro Lima } \\
\text { Abrahão Sanovicz }\end{array}$ \\
\hline & $\begin{array}{l}\text { Cadeira } 15 . \\
\text { Projeto II }\end{array}$ & $\begin{array}{l}1963-67 \\
1965-67 \\
1966-67\end{array}$ & $\begin{array}{l}\text { Abelardo Riedy de Souza } \\
\text { Jon Andoni Vergareche Maitrejean } \\
\text { Miranda Maria Magnoli }\end{array}$ \\
\hline & $\begin{array}{l}\text { Cadeira } 18 . \\
\text { Planejamento I }\end{array}$ & $1963-67$ & Roberto Coelho Cardozo \\
\hline & $\begin{array}{l}\text { Cadeira } 22 . \\
\text { História da arquitetura II }\end{array}$ & $1963-67$ & Nestor Goulart Reis Filho \\
\hline \multirow[t]{8}{*}{$4^{\circ}$ ano } & $\begin{array}{l}\text { Cadeira } 8 . \\
\text { Hidráulica e saneamento }\end{array}$ & $\begin{array}{l}1963-66 \\
1967\end{array}$ & $\begin{array}{l}\text { Lucas Nogueira Garcez } \\
\text { Paulo Sampaio Wilken }\end{array}$ \\
\hline & $\begin{array}{l}\text { Cadeira } 9 . \\
\text { Construção II }\end{array}$ & $\begin{array}{l}1963-1964 \\
1965-1967\end{array}$ & $\begin{array}{l}\text { José de Oliveira Escorel } \\
\text { Renato Salmoni }\end{array}$ \\
\hline & $\begin{array}{l}\text { Cadeira } 10 . \\
\text { Estruturas correntes de } \\
\text { madeira, metálicas e de } \\
\text { concreto armado e simples }\end{array}$ & $1963-67$ & José Carlos de Figueiredo Ferraz \\
\hline & $\begin{array}{l}\text { Cadeira } 11 . \\
\text { Grandes estruturas }\end{array}$ & $1963-67$ & Pedro Bento José Gravina \\
\hline & $\begin{array}{l}\text { Disciplina autônoma } 134 . \\
\text { Desenho industrial IV }\end{array}$ & $\begin{array}{l}1966-67 \\
1967 \\
1967\end{array}$ & $\begin{array}{l}\text { Luiz Roberto Carvalho Franco } \\
\text { Luiz Roberto de Castro Lima } \\
\text { João Carlos Rodolpho Stroeter }\end{array}$ \\
\hline & $\begin{array}{l}\text { Cadeira } 16 . \\
\text { Projeto III }\end{array}$ & $1963-67$ & $\begin{array}{l}\text { Roberto Cerqueira Cesar } \\
\text { Ariaki Kato } \\
\text { Roger Zmekhol }^{\mathrm{m}}\end{array}$ \\
\hline & $\begin{array}{l}\text { Cadeira } 19 . \\
\left.\text { Planejamento II ( } 1^{\text {a }} \text { parte }\right)\end{array}$ & $1963-67$ & Lauro Bastos Birkholz \\
\hline & $\begin{array}{l}\text { Cadeira } 23 . \\
\text { História da arquitetura III }\end{array}$ & $1963-67$ & Eduardo Kneese de Mello \\
\hline
\end{tabular}




\section{As disciplinas do Departamento de Tecnologia}

Em 1964, os Departamentos de Ciência Aplicada e de Construção seriam fundidos num só Departamento de Tecnologia da Arquitetura ${ }^{88}$. Algumas cadeiras tiveram seu conteúdo condensado ou foram reagrupadas. Para nosso trabalho interessam particularmente a Cadeira de Construção I, ministrada por Ariosto Mila, sua atuação docente e a de Luiz Cintra do Prado.

A Cadeira 6, Construção I (antiga Cadeira 9 - Técnicas de construção, organização do trabalho, prática profissional e higiene dos edifícios) teve seu conteúdo condensado para ser ministrado só para o $3^{\circ}$ ano ${ }^{89}$. De 1963 até 1965, o conteúdo permanece igual ao trabalhado antes da reforma. Mas em 1966 e 1967, Aristo Mila acrescentou na ementa alguns tópicos sobre industrialização e pré-fabricação, possivelmente embalado pela novidade do DI no ensino de projeto, além de ter descrito que iria iniciar as aulas apresentando a evolução da técnica de construção, desde o artesanato, passando pelo "tradicional evoluído" até a definição do que seria "pré-fabricação parcial" e "pré-fabricação total”. Esses itens nos fazem pensar que Ariosto, talvez, não possuísse uma visão histórica do que fosse artesanato, indústria, ou uma manufatura precária, considerando o segundo a evolução óbvia do primeiro.

Nestas ementas era somente em relação à estrutura e às vedações (em concreto, não outro material) que o tema da industrialização e da pré-fabricação aparece e não há menção à possibilidade de industrialização dos equipamentos hidrosanitários, elétricos, esquadrias e outros sistemas e elementos, ou ainda ao fato de muitos destes produtos já o serem. Os exercícios propostos talvez indiquem até onde o tema era trabalhado ou até onde ia o domínio do docente - pré-fabricação de estruturas trata apenas de um relatório de visita técnica a uma obra em que existissem elementos pré-fabricados sendo instalados; para vedações seriam realizados detalhamento de tabiques pré-fabricados em madeira (exercício que nem trazia uma novidade à construção civil brasileira à época) - mas também indicam até onde ia a vontade do docente, que escreveu nos tópicos de seu plano de ensino a intenção de "criticar as técnicas de construção e especular novos processos construtivos" e propôs o projeto de um "painel hidráulico pré-fabricado" (e sabe-se lá se isso resultou no desenho de kits hidráulicos montados ao pé da obra ou se resultaram em bloco técnicos hidráulicos, tão em voga na época).

88 DEL CARLO, 2007.

89 O conteúdo de mecânica dos solos foi transformado, inicialmente, na disciplina autônoma 61 "Mecânica dos solos e fundações", que funcionou de 1963 a 1965, quando foi transformada, por meio da Portaria n.202 de 1 de dezembro de 1965, na Cadeira 26. 


\section{Grade curricular pós-1962}

\begin{tabular}{|c|c|c|c|}
\hline \multirow[t]{5}{*}{$5^{\circ}$ ano } & $\begin{array}{l}\text { Cadeira } 17 . \\
\text { Projeto IV }\end{array}$ & $\begin{array}{l}1966-67 \\
1966 \\
1966\end{array}$ & $\begin{array}{l}\text { João Baptista Vilanova Artigas } \\
\text { Paulo Mendes da Rocha } \\
\text { Pedro Paulo de Mello Saraiva }\end{array}$ \\
\hline & $\begin{array}{l}\text { Cadeira } 19 . \\
\text { Planejamento II }\left(2^{\mathrm{a}}\right. \\
\text { parte })\end{array}$ & 1956 & Lauro Bastos Birkholz \\
\hline & $\begin{array}{l}\text { Cadeira } 24 . \\
\text { História da arquitetura } \\
\text { IV }\end{array}$ & $1966-67$ & Eduardo Corona \\
\hline & $\begin{array}{l}\text { Cadeira } 25 . \\
\text { Estudos sociais e econô- } \\
\text { micos }\end{array}$ & $1963-67$ & Juarez Brandão Lopes \\
\hline & $\begin{array}{l}\text { Cadeira } 26 . \\
\text { Mecânica dos solos e } \\
\text { fundações }\end{array}$ & $1966-67$ & Vitor Froilano Bachmann de Mello \\
\hline
\end{tabular}


Desde a mais antiga ementa encontrada, de 1953, e em outros documentos ${ }^{90}$, nota-se que Ariosto Mila enxergava a disciplina de Construções Civis como um repertório de sistemas e processos construtivos e que a obra arquitetônica é o agrupamento de elementos fracionados, à maneira da casa Domino ou das teorias de Le Corbusier (apontadas no primeiro capítulo), tão citado em seus trabalhos. E porque era conhecedor dos sistemas, dos processos e das técnicas construtivas é que possuía referência do que era industrializado à época. Tanto é assim que, quando Ariosto fala em industrialização, aponta elementos existentes e utilizados àquela época, especialmente remetendo à produção de grandes painéis em concreto. Mas não fala em industrialização do ponto de vista do projeto, da elaboração de componentes ou sistemas construtivos.

Na tese que apresentou para se tornar catedrático de Construções I (MILA, 1967), em 1967 - e citanto Le Corbusier: "a habitação se define portanto como um complexo de elementos associados, tendo em vista finalidade utilitária, e que constituem órgãos em conexão mútua com um organismo natural" consolidou a "organização" dos sistemas construtivos no sentido mais literal possível, associando-os com a biologia. Associa a fisiologia da edificação com sua função, enquanto objeto utilitário, como o espaço organizado; a anatomia da edificação com os órgãos ou obras que integram o edifício; e a histologia como a conceituação do tecido construtivo ou como a técnica, os materiais necessários e sua manipulação. Essa esquematização é resumida nos diagramas (Mila, 1967, pág. 14) em que a concepção arquitetônica é sintetizada pelo binômio forma-função, e a construção pelo binômio forma-estrutura.

E, depois de apresentar a tese em que relaciona o edifício a um organismo vivo, discorre sobre as diferenças de produtividade entre a construção (dita) artesanal, a mecanizada e a préfabricada - a primeira dependente do "esforço muscular humano" cujo rendimento dependia do número de braços; a segunda como o tratamento maquinal dos materiais para uma construção limitada, cujo rendimento estava condicionado à capacidade do equipamento; e a terceira como a produção automatizada em usinas com rendimento contínuo em grande escala e montagem generalizada de habitações - baseando sua definição na experiência de produção dos grandes painéis europeus e soviéticos de concreto.

Em sua tese ainda dedica um capítulo à "tecnologia da pré-fabricação", em que apresenta questões sobre a teoria da coordenação modular, sobre os tipos de materiais que poderiam ser aplicados na industrialização (o aço, a madeira, o concreto) e faz referências à atuação de Gerard Blachére e ao papel do CSTB, na França, e do Instituto Científico e de Investigação

$90 \quad$ MILA, 1954 e MILA, 19-? 
Técnica da Construção da URSS na produção de habitações com grandes painéis. Completa seu trabalho com uma amostra do detalhamento dos principais tipos de ligação entre vigapilar, pilar-pilar, viga-laje e entre painéis parede-laje e parede-parede (painéis horizontais e verticais).

Ariosto não foi o primeiro a sistematizar os processos construtivos em órgãos ou em partes similares, de mesma função, mas foi, provavelmente, quem se aproveitou academicamente da possibilidade de sistematizar as partes constituintes do edifício. Além disso, conhecedor dos processos construtivos, foi talvez quem mais se aproximou dos conceitos da industrialização e da mecanização da construção, tendo passado esses conceitos em aula.

Na Cadeira 5 - Física geral e aplicada, a ementa sofreu pouca alteração desde o início do curso: ainda eram estudadas as matérias de iluminação, eletricidade, acústica e termologia do ponto de vista da física e da sua aplicação no projeto de arquitetura. Mas era a atuação de Luiz Cintra do Prado, responsável pela cadeira, que nos interessa. A cadeira de Física Geral e Aplicada possuía à época o papel das disciplinas de Conforto Ambiente nos currículos dos cursos de Arquitetura hoje. Seu responsável, Luiz Cintra do Prado - engenheiro eletricista formado na Escola Politécnica - tinha um apreço pelo estudo do desempenho e característica física dos materiais de construção, especialmente pela acústica, e mantinha contato com o Centro Científico e Tecnológico da Construção, na França, cujo diretor, Gerard Blachére, era também seu amigo ${ }^{91}$.

Luiz Cintra do Prado teria mandado então alguns estudantes seus, entre os quais Leo Quanji Nishikawa e Ualfrido Del Carlo, para realizar estudos no CSTB sobre desempenho de edifícios e de materiais. E alguns docentes do CSTB também teriam vindo no final dos anos 1960 para dar aulas de não só de conforto acústico e térmico na FAU, como Robert Josse em 1966 e Jean Claude Borel em 1969. Jean Lugez, engenheiro no CSTB, também viria à FAU para proferir uma palestra no seminário "A Industrialização da Construção na França" em junho de $1966^{92}$.

À época, o CSTB possuía papel fundamental na reconstrução da França: conforme BRUNA ${ }^{93}$, o Centro era responsável, entre outras atividades, por avaliar o desempenho ambiental (acústico, térmico, lumínico, entre outros itens) das patentes - edifícios industrializados a partir de um processo construtivo patenteado de montagem de painéis - em laboratório e em

$91 \quad$ Essa história é contada por DEL CARLO, 2007.

92 Sobre essa palestra há referência em BRUNA (1970) e em Problemas da pré-fabricação. O Dirigente Construtor. São Paulo, v. 2, n. 9, p. 9, jul. 1966. Editorial.

93 BRUNA, 1976. 
canteiro experimental antes de serem construídas no local final. Gerard Blachére, engenheiro civil, entusiasta da industrialização e responsável pela difusão de muitos conceitos sobre o tema, defendendo-o, foi diretor do Centro Científico e Tecnológico da Construção, o CSTB (Centre Scientifique et Technique du Bâtiment) na França, de 1957 a 1974², período de intensa atividade do Centro na reconstrução da França, principalmente, no pós-guerra. Mas o desempenho do edifício, que o CSTB abordava como qualidades que um produto industrial deveria atender, na FAUUSP seria abordado na forma de dados a serem satisfeitos só na etapa de projeto.

A atuação de Luiz Cintra do Prado e de Ariosto Mila parece ter convergido em algum momento. Durante os anos 1970, Teodoro Rosso - contratado para integrar o Departamento de Tecnologia em 1973, conforme depoimento de Nestor Goulart Reis Filho ${ }^{95}$ - Luiz Cintra do Prado e Ariosto Mila teriam organizado ao menos um "Curso de racionalização e industrialização da construção" em nível de pós-graduação, conforme documento ${ }^{96}$ localizado na biblioteca da FAUUSP.

\section{As disciplinas do Departamento de Projeto}

De 1963 a 1967, na sequência de DI, o desenho industrial é abordado de forma bastante abrangente em relação aos conceitos e ferramentas específicos da disciplina e os exercícios resultam, ainda que dentro de uma proposta legítima, em projetos de bens de consumo, conforme os exemplos apresentados em publicação de $1963^{97}$, sobre a experiência do desenho industrial na reforma de 1962. Chamamos a atenção para as opções de trabalho que os docentes fizeram em algumas disciplinas, apresentadas a seguir.

Em Desenho Industrial I - Disciplina 131, em 1966 e 1967, foram elaborados jogos e brinquedos componíveis a partir de conceitos de "geometria das formas", "simetria", "coordenação modular" e "topologia", conceitos estes que também podem ser aplicados na elaboração de componentes de construção civil.

94 Conforme sítio online do CSTB: http://www.cstb.fr/archives/webzines/editions/webzine-du-4-juillet2011 /gerard-blachere-scientifique-du-batiment.html

$95 \quad$ Entrevista concedida em 08 de abril de 2015.

96 O curso teria sido organizado por Ariosto Mila, Luiz Cintra do Prado e Teodoro Rosso com a colaboração de Paulo Bruna, Paulus Aulus Pompéia e José Luiz Junqueira e com metodologia elaborada por Suzana Pasternak Taschner. Por indicação no interior do documento acreditamos que o curso foi elaborado no início dos anos 1970. Não pudemos, no entanto verificar se o curso foi realizado. FONTE: MILA, Ariosto (et all). Projeto do curso de racionalização e industrialização da construção. São Paulo: FAUUSP, s/d. Mimeo.

97 Não foi possível localizar trabalhos didáticos que refletissem as ementas de DI e Projeto de 1963 a 1970. Somente a publicação do Departamento de Projeto com o resultado das atividades de 1962 (FAUUSP, 1963) apresenta os exercícios trabalhados em DI, ou alguns artigos de revista como O Dirigente Construtor. 
Na outra vez em que a "coordenação modular" foi abordada, em 1968, os exercícios elaborados se referiam a projeto de sistemas componíveis de móveis ou conjuntos coordenados de aparelhos de jantar e cozinha ${ }^{98}$.

Em Desenho Industrial III - Cadeira 13 os exercícios consistiam em "linhas de objetos", tema justificado e "fundamentado nas implicações do DI nos equipamentos da habitação", a partir do "estudo das zonas de habitação que compreendem as atividades da higiene, cocção e serviços gerais"99. Apesar da ementa indicar que seriam dadas "noções de elementos de préfabricação (painéis divisórios, forros, etc)", os exercícios muito provavelmente resultaram em bens domésticos ou outra coisa que não componentes de construção civil.

No entanto, não nos interessam tanto as disciplinas de Desenho Industrial como as disciplinas de Projeto de Arquitetura. Como se viu desde 1953 as ementas mais antigas, o pouco que estas se aproximavam da industrialização da arquitetura não passava de alguns cacoetes estilísticos herdados dos referenciais canônicos da arquitetura moderna internacional. E mesmo as obras dos docentes de Composição de Arquitetura - como Hélio de Queirós, Zenon Lotufo, Oswaldo Correia Gonçalves, Rino Levi, Roberto Cerqueira César, Abelardo Riedy de Souza ou mesmo João Batista Vilanova Artigas, que advogavam pela arquitetura moderna em detrimento da eclética - não passavam de concepções estilísticas na forma que dialogavam com os preceitos da arquitetura moderna ou, ainda que involuntariamente, com os princípios da eficiência da administração científica. Ou melhor, a produção arquitetônica desses docentes se aproximava da arquitetura moderna em relação ao programa arquitetônico, à funcionalidade do conjunto de ambientes e ao lay-out, principalmente, do interior. Não em relação ao projeto para uma produção mecanizada ou para um canteiro menos precário. Além disso, as disciplinas refletiam essa condição e os exercícios das disciplinas abordavam um projeto de arquitetura para edifícios com ambientes cujo arranjo funcionasse nos novos tempos.

O único docente que, no início dos anos 1960, talvez já tivesse se aproximado um pouco mais do desenho industrial no projeto de arquitetura foi Millán.

Carlos Barjas Millán, arquiteto formado Arquiteto em 1951 no Mackenzie, iniciou a docência na cadeira de Composição de Arquitetura, do quarto ano na FAUUSP em 1959 a convite do professor Roberto de Cerqueira César, depois de uma greve de estudantes que reivindicavam docentes de projeto cuja prática profissional dialogasse mais com as proposituras da 98 PICARELLI, 1968.

99 FAUUSP. Programa de Disciplinas de 1966. Sequência de Desenho Industrial. São Paulo, FAUUSP, 1966. 
arquitetura moderna e menos com a repetição de estilos. Conforme os documentos, ementas e programas de disciplinas localizados até o momento, Millán permaneceu na docência de projeto na FAUUSP até a data de sua morte, em 1964.

Em sua prática profissional Millán desenvolveu um refinado desenho de arquitetura modulada. Carlos Faggin (1987) aponta as duas fases profissionais por que passou: a primeira culminou com a Residência Fujiwara, influenciado principalmente por Richard Neutra, em que demonstra um domínio do uso da pedra e madeira no projeto; a segunda representa seu amadurecimento, quando casas-apartamento são projetadas sobre pilotis e o uso de concreto armado aparente demonstra clara influência de Le Corbusier, como a Residência Roberto Millán, de 1960. Nesta fase, passa a utilizar a pré-fabricação de alguns elementos em concreto na edificação e colabora com a empresa Eternit ${ }^{100}$, a convite desta e em caráter experimental, para realizar um protótipo de casa industrializável. Millán enfrentou com dificuldade o detalhamento dos montantes de madeira para a fixação de painéis; por outro lado, propôs o desenho de painéis sanduíche e das placas corrugadas que a empresa passou a produzir. Em Acrópole também seria publicado, em edição que homenageava o arquiteto depois de sua morte, um projeto incompleto para uma fábrica "dedicada à produção de pré-moldados de concreto" $"$.

Os estudos sobre sua obra, no entanto, abordam muito pouco os materiais e técnicas construtivas utilizadas e entram pouco no mérito sobre como o arquiteto entendia a industrialização. Millán entendia a pré-fabricação como forma de dialogar com a estética da indústria, a que preconizava o Movimento Moderno, ou como experimentação sobre as possibilidades de produção em massa? Entre as disciplinas de projeto ainda, escolhemos uma que consideramos bastante interessante para ilustrar qual era a pauta de modernidade considerada nas disciplinas de projeto. A Cadeira 15, Projeto II, apresentava na ementa de 1967 para o $3^{\circ}$ ano o "desenvolvimento de projetos de edifícios isolados e seu detalhamento". Sob coordenação do prof. Abelardo Riedy, em que participaram os professores instrutores Miranda Maria Magnoli e Jon Maitrejean, foi proposto aos alunos o estudo de uma unidade habitacional para 5.000 pessoas, operárias de uma Cia. Hidroelétrica no Paraná. A ementa trazia a curiosa nota "fica vedado, por questões didáticas, o uso de construções pré-fabricadas". Jon Maitrejean nos apontou ${ }^{102}$ que, possivelmente, Abelardo quisesse focar em outros aspectos do projeto que não a sua produção.

100 Residência Eternit. Acrópole. São Paulo, n. 332, p. 22-23, set. 1966. Planejamento industrial. Acrópole. São Paulo, n. 332, p. 38-39, set. 1966.

101 Planejamento industrial. Acrópole. São Paulo, n. 332, p. 38-39, set. 1966.

102 Em entrevista concedida em 12 de setembro de 2015. 
Ora, não é o canteiro de obras de uma Hidroelétrica um dos mais violentos com a força de trabalho? A discussão da pré-fabricação leva, invariavelmente, à discussão do canteiro de obras e das condições de trabalho, seja de um canteiro de uma habitação, de um conjunto de habitações, seja de um canteiro de hidroelétrica. A pauta da modernidade, da grande indústria e do desenvolvimentismo brasileiro entra então na discussão de Projeto de Arquitetura sob a forma do estudo de habitação para a reprodução da força-de-trabalho do grande capital. Esse parecia ser o foco e preocupação dos projetos, o grande capital, e não discutir a industrialização, mesmo que para o projeto de habitação para um cidadão, independentemente dele ser força-de-trabalho ou não.

Pensamos ainda que, pretendendo Abelardo focar em outras questões que não a produção da edificação, seria possível que os próprios estudantes estivessem trazendo essas questões a partir de referências externas? Ou, estariam os estudantes incomodando um docente que talvez não soubesse lidar com o desenho industrial?

Em 1968, já com a nova reorganização das disciplinas do Departamento de Projeto, Abelardo - responsável pela disciplina de Projeto III, do $4^{\circ}$ ano - propõe aos estudantes o projeto de um "núcleo que substituirá a sede atual do Município de Igaratá, situado na periferia do Grande São Paulo" e que seria desenvolvido em conjunto com as disciplinas de Planejamento, Comunicação Visual Alternativo e Desenho Industrial Alternativo ${ }^{103}$, o que nos faz imaginar um exercício de projeto total, em uma escala urbana que dialogasse com a do edifício e a dos objetos, talvez até mesmo a dos componentes de construção civil, já que a ementa também determinava que deveria ser feita a "proposição de um Plano de Massa para todo o núcleo urbano, acompanhado do sistema construtivo para a infra-estrutura dos edificios" ${ }^{\prime 104}$. Mas, quando se lê a ementa de Desenho Industrial Alternativo do $4^{\circ}$ ano ${ }^{105}$, a disciplina de Lúcio Grinover trabalharia o projeto da sinalização urbana de Igaratá.

103 A nova grade curricular de 1968 a 1970 definia algumas disciplinas alternativas (atualmente chamadas de optativas) que deveriam ser cursadas pelos alunos no $2^{\circ}$, no $3^{\circ}$ e no $4^{\circ}$ ano. Localizamos algumas dessas ementas, preservadas no arquivo do Departamentos de Projeto, entre as quais as citadas anteriormente.

$104 \operatorname{SOUZA}($ et. All), 1968.

105 GRINOVER, 1968 


\section{Grade curricular do período 1968-1970}

\begin{tabular}{|c|c|c|}
\hline \multirow[t]{8}{*}{$1^{\circ}$ ano } & Projeto I ( $1^{\text {a }}$ parte $)$ & $\begin{array}{l}\text { Hélio de Queirós Duarte } \\
\text { Siegbert Zanettini } \\
\text { Pedro Paulo de Melo Saraiva } \\
\text { Dario Montesano }\end{array}$ \\
\hline & Planejamento & Lauro Bastos Birkholz \\
\hline & & Roberto Coelho Cardozo \\
\hline & Desenho industrial I & João Carlos Cauduro \\
\hline & & Eduardo de Almeida \\
\hline & Comunicação visual I & João Baptista Alves Xavier \\
\hline & & Luiz Gastão de Castro Lima \\
\hline & & Élide Monzéglio \\
\hline \multirow[t]{9}{*}{$2^{\circ}$ ano } & Projeto I ( $2^{\mathrm{a}}$ parte $)$ & Paulo Mendes da Rocha \\
\hline & & Jon Maitrejean \\
\hline & & Miranda Magnoli \\
\hline & & Antônio Augusto Antunes Netto \\
\hline & & Mièton Carlos Ghiraldini \\
\hline & Desenho industrial II & Marlene Picarelli \\
\hline & & Ronaldo Duschenes \\
\hline & Comunicação visual II & Renina Katz Pedreira \\
\hline & & Flávio Império \\
\hline \multirow[t]{7}{*}{$3^{\circ}$ ano } & Projeto II & Roger Zmekhol \\
\hline & & Gian Carlo Gasperini \\
\hline & Planejamento & Brenno Cyrino Nogueira \\
\hline & & Marcos de Souza Dias \\
\hline & Desenho industrial III & João Carlos Rodolpho Stroeter \\
\hline & & Abrahão Sanovicz \\
\hline & Comunicação visual III & Ludovico Antonio Martino \\
\hline \multirow[t]{6}{*}{$4^{\circ}$ ano } & Projeto III & Abelardo Riedy de Souza \\
\hline & & Cândido Malta Campos Filho \\
\hline & & Roberto José Goulart Tibau \\
\hline & Planejamento & José Cláudio Gomes \\
\hline & Desenho industrial IV & Lúcio Grinover \\
\hline & Comunicação visual IV & consta no horário, mas não possui professor \\
\hline $5^{\circ}$ ano & Projeto IV & João Baptista Vilanova Artigas \\
\hline
\end{tabular}


Os debates sobre a reforma universitária de 1968 e a reforma curricular da FAUUSP de $1968^{106}$ eram apresentadas por Eduardo Corona em Acrópole ${ }^{107}$ e consideravam a necessidade da interdisciplinaridade na formação do arquiteto. Ainda em 1968 a escola se mobilizava para organizar o ensino em torno de uma pesquisa mais consequente sobre a arquitetura, "sobre o desenvolvimento brasileiro [...] à luz da compreensão das condições do subdesenvolvimento e das possibilidades que se abrem para ultrapassá-lo"108 e que resultou na criação do ateliê interdepartamental e das unidades alternativas de ensino (hoje disciplinas optativas) que possibilitariam uma flexibilidade na formação dos estudantes de arquitetura atendendo, de certa maneira, às exigências por interdisciplinaridade.

Em 1970 parece ter havido um salto de amadurecimento do ensino de projeto. O Departamento de Projeto teria se reunido e elaborado uma proposta ${ }^{109}$ de trabalho com temas que englobavam o desenho industrial, a comunicação visual, o projeto e o planejamentos como questões transversais a serem trabalhadas simultaneamente. Para o $1^{\circ}$ ano, o respectivo grupo de docentes do $1^{\circ}$ ano (já em formação diversa daquela apresentada na grade didática de 1968-1969) organiza uma série de palestras com a finalidade de "abordar os problemas do "meio" arquitetônico através de uma "tempestade" de informações criando um mosaico fragmentado" e que seriam, num primeiro momento, debatidas entre os estudantes. As palestras abordavam repertórios de "fixação e mobilidade", "concentração e rarefação", "sinais, signos, símbolos", "matéria, espaço, tempo", "unitário, grupo, coletivo", "elementos de estruturação formal", "produção e consumo" e "técnicas e processos".

Para os outros anos, as mesmas palestras seriam o início de atividades de pesquisa - com a finalidade de produzir "conjuntos de conhecimentos interdependentes não setorizados", ou seja, interdisciplinares - que informariam o trabalho de projeto de cada equipe. Cada equipe de estudantes lidaria com um tema de projeto específico, e todos os temas deveriam abordar as 4 linhas disciplinares do Departamento de Projeto (Desenho Industrial, Projeto da Edificação, Planejamento e Comunicação Visual). Alguns desses temas remetiam à implantação de

106 Para um entendimento sobre o contexto político por que passava a FAUUSP e sua comunidade à época, apontamos os seguintes textos para consulta:

ARTIGAS. J.B.V. Contribuição para o relatório sobre o ensino de arquitetura, UIA - UNESCO, 1974 in SINOPSES: Memória. São Paulo: FAUUSP, Edição Especial, 1993. ISSN: 0101-7225.

Fórum: o percurso do ensino na FAU. Revista Caramelo. São Paulo, Gfau - FAUUSP, outono 1993, n.6, pág. 9-22. Editorial. ISSN 0104-0251

107 Encontro Nacional de Ensino de Arquitetura 1967. Acrópole. São Paulo, n. 345, p. 14, nov. 1967.

CORONA, mai. 1968.

108 CORONA, jun. 1968.

109 ZANETTINI, Siegbert et alli. Departamento de Projeto - Proposta de programação didática e de pesquisa. São Paulo, FAUUSP, 1970. Mimeo. 
conjuntos habitacionais em localidade específica (Planejamento / Projeto da edificação), para os quais deveriam ser desenvolvidos sistemas construtivos pré-fabricados em determinado material (DI), com estudo cromático para a organização dos ambientes da casa (Comunicação Visual / Projeto da Edificação).

A intenção dos docentes, talvez, fosse extrapolar a mera formação profissional em direção à formação intelectual e, a partir das pesquisas, produzir com os estudantes material crítico ${ }^{110}$.

Os docentes informavam aos estudantes de que aquele era o "início de um processo mais consequente entre trabalhos da FAU e a comunidade, com vistas à melhoria do ensino" e que deveria "chegar à formação de um Centro de Pesquisas e Projetos do tipo CEPLAN", curiosamente no mesmo ano em que a revista Acrópole publicaria, pela primeira vez, os trabalhos do GEPLAN ${ }^{111}$ (Centro de Planejamento da Universidade de Brasília) elaborados pelos arquitetos João Filgueiras Lima e Oscar Niemeyer, desenvolvidos desde 1962.

110 O depoimento de Artigas (s/d) a Lívia Pedreira aponta que essa era intenção da reforma universitária, provavelmente em 1968, mas que não foi levada à cabo por conta da burocracia da estrutura universitária.

111 Acrópole. São Paulo, n. 369/370, jan-fev 1970. Edição especial sobre a Universidade de Brasília. 
Gapítulo 3

As ReVistas de ARQUitetura e aS REFERÊNGIAS DO PERÍODO 
Não está entre os propósitos dessa dissertação definir o significado de industrialização. No entanto, indústria ou industrialização (e outros similares) eram termos que algum significado possuíam para os personagens internos e externos à FAUUSP naquele momento. Quer dizer, se tomada a reforma curricular de 1962 como exemplo, esta foi justificada ${ }^{112}$ pela necessidade de ampliar a formação do arquiteto para prepará-lo para as novas solicitações de uma indústria nacional em desenvolvimento. Mas, o que seria essa indústria em desenvolvimento? O que seria ou deveria ser industrializado? Ecomo seria industrializado, na opinião dos arquitetos?

E ainda, como verificar se a comunidade da FAUUSP era alvo (e também agente) de um conjunto de ideias e referências sobre industrialização? Quais eram as ideias da comunidade interna da FAUUSP e de seus interlocutores externos sobre industrialização? Quais eram essas referências sobre industrialização da arquitetura? Havia referências de produção nacional e internacional? De que modo essas referências chegavam e eram percebidas pelos docentes? Quem promovia e quais eram os debates sobre industrialização no período do lado de fora da FAU?

A mídia impressa da época talvez seja a melhor fonte de respostas, principalmente as revistas especializadas. Até mesmo as viagens dos arquitetos, pelas quais muitos deles entravam em contato com a produção e com o debate internacionais, eram noticiadas pelas revistas especializadas.

E como o discurso aparece nas revistas do circuito profissional da arquitetura em São Paulo no período? Quais são os assuntos que giram em torno da industrialização? Quais são os elementos do discurso? Quem escrevia esses textos?

Ao menos vinte publicações especializadas em arquitetura, urbanismo e engenharia estavam disponíveis (ou eram editadas) no período estudado, 1948 a 1968. A biblioteca online do

112 FAUUSP, 1963 (c). 
grupo de pesquisa MOM - Morar de outras maneiras ${ }^{113}$, da UFMG, apresenta um extenso levantamento sobre o tema Habitação com 33 revistas especializadas em arquitetura e urbanismo entre todas as que foram editadas no Brasil desde a década de 1920 a 2000: desde uma das mais antigas, a revista A Casa, publicada de 1927 a 1941, passando por Acrópole, publicada de 1938 a 1971, AD - Arquitetura e Decoração, publicada de 1953 a 1958, Habitat, publicada de 1950 a 1965, a O Dirigente Construtor, publicada de 1964 a 1992, a Revista Módulo, publicada de 1955 a 1989, até a atual Revista Projeto, publicada desde 1979, entre outras. Havia, portanto, farto material em que arquitetos urbanistas, outros profissionais e empresas do setor discutiam o ambiente de trabalho, apresentavam produtos e defendiam ideias.

Para entender um pouco sobre esse meio, verificar se havia algum debate sobre industrialização da arquitetura e tentar ainda responder todas as perguntas elaboradas foram selecionadas Habitat, O Dirigente Construtor e Acrópole por terem sido contemporâneas ao período estudado e por terem existido por tempo suficiente para os debates de uma época. $\mathrm{O}$ tempo de vida das revistas indicaria inclusive o alcance que possuíam de leitores interessados em seus conteúdos ${ }^{114}$.

E, mesmo constituindo material elaborado para um setor muito específico, cada revista apresenta abordagem muito diferente dos mesmos temas. Por exemplo, a publicidade em Habitat é tratada de forma muito diferente do que é na O Dirigente Construtor, cujo enfoque dado às obras de arquitetura, sob o ponto de vista do canteiro e dos processos construtivos, é muito diferente da abordagem que Acrópole faz dos mesmo projetos, muitas vezes exaltando o projeto e o projetista.

O tema da industrialização nas revistas dificilmente aparece sozinho. É bastante associado aos debates sobre déficit habitacional, planejamento e desenvolvimentos urbano - também associados após 1964 aos debates sobre a atuação do Banco Nacional da Habitação e do Plano Nacional de Habitação - promovidos pelas entidades ou profissionais envolvidos ou entusiastas do assunto, e que expressam muito das expectativas do período. A industrialização também aparecia como sinônimo de inovação, nos artigos que relatavam obras nacionais ou estrangeiras. Muitas dessas referências seriam responsáveis por ter incentivado um imaginário sobre o tema.

113 MOM - Morar de outra maneira. Disponível em htp://www.mom.arq.ufmg.br/mom/

114 A revista Módulo também se encaixa neste perfil traçado para a seleção de material. Por tempo útil de trabalho, no entanto, não foi possível realizar a análise desse material e ficamos somente com revistas paulistas. 
Mas, sem dúvida, era na publicidade que muitos produtos ou ideias seriam divulgados sobre o tema, considerando-se que a publicidade é um evento próprio do modo industrial de produção. As revistas estavam repletas de publicidade de produtos de interiores e de construção civil, obviamente industrializados, que apresentam provavelmente com bastante fidelidade um panorama do consumo, o que era produzido e estava disponível no momento. 


\section{Publicidade, vitrines e empresas brasileiras}

\section{Habitat}

Não por acaso eram incluídos em Habitat muitas peças publicitárias e artigos sobre vitrines e lojas de móveis e eletrodomésticos. Não se tratava somente de divulgar a marca ou o autor do projeto de interior da loja, mas de civilizar o gosto da elite paulistana. Ethel Leon (2006) aponta que Bardi se sentia horrorizado com o mal gosto e provincianismo da elite paulistana, ao visitar suas residências com Assis Chateaubriand, que buscava apoio para a fundação do MASP, e se indagava em que condições esta se tornaria a mecenas do novo museu.

A revista Habitat, braço editorial do MASP naqueles primeiros anos de existência, era parte do tripé revista-acervo-escola engendrado por Pietro Bardi em informar e formar o gosto daqueles que se esperava também fossem elite intelectual de um país que se modernizava. A revista dirigida nesses primeiros anos por Lina Bo e Pietro Maria Bardi possuía um caráter especialmente elitista, que em nada se parecia com a última revista fundada e dirigida por Lina na Itália no pós-guerra, Revista A - Cultura della Vita, que tinha um caráter popular em debater o cotidiano e a cultura da modernidade ${ }^{115}$, em educar e dar conselhos sobre a casa.

Habitat não dá conselhos sobre a casa, mas anuncia a produção de "decorações e objetos de artesanato" "116 de "jovens arquitetos conhecidos por suas preferências modernas" — entre os quais Carlos Millan, Chen Y.S. Hwa, Jacob Maurício Ruchti, Miguel Forte, Plinio Croce e Roberto Aflalo - comercializados pela loja Branco e Preto - e Lina Bo Bardi, Giancarlo Panlanti, M Zanuso e H. Orro, entre outros - comercializados pela loja Ambiente, a primeira do tipo a ser aberta em São Paulo ${ }^{117}$. Qual adjetivo qualificaria uma pessoa avessa a “jovens arquitetos conhecidos por suas preferências modernas"? Ou seja, Habitat educa o gosto indiretamente por meio dos artigos e publicidades e também por meio das notas ácidas e sarcásticas da seção Alencastro, escritas por Lina e Pietro para ironizar genericamente o gosto da elite paulistana.

E, apesar da mudança de direção da revista a partir da saída do casal Bardi, em 1954, os artigos sobre o interior das lojas e seus produtos ainda são publicados até o final da década de

115 RUBINO, 2009.

116 Branco e preto. Habitat. São Paulo, n. 9, p. 89, out-dez. 1952. Seção Alencastro.

117 FONGARO, Carlo B. Ambiente. Habitat. São Paulo, n. 50, p. 30-33, set-out. 1958. 
1950 (isso quando não aparecem em formato de peça publicitária), contribuindo com "o tom de atualidade no campo da decoração" e o "progresso do gosto".

Além da formação civilizadora do gosto por meio da revista, esta também servia ao propósito de divulgar os eventos culturais ${ }^{118}$ organizados por Bardi na sede do MASP à Rua Sete de Abril, no centro da cidade de São Paulo, que contavam com a participação de empresários do setores afins como forma de aproximar o setor produtivo dos debates de modernização do país por meio da produção de bens.

Pela revista, no começo dos anos 1950, o casal Bardi advogava pela produção de bens em massa $^{119}$ ao mesmo tempo em que apontava a necessidade de uma escola nacional de formação de desenhistas industriais modernos capacitados a lidar com os novos materiais e suas possibilidades estéticas e desafiava a indústria a formar seus próprios artistas caso quisesse se fundamentar sobre alicerces apropriados. Novamente, a revista aponta a necessidade de articulação com o empresariado nacional. E na sequência dos textos em que defendiam a necessidade de criação de escolas para a formação de desenhistas industriais, Habitat anunciava as atividades educativas do Instituto de Arte Contemporânea ${ }^{120}$, discutia o ensino de arquitetura na FAUUSP ${ }^{121}$, a inauguração da ESDI ${ }^{122}$, em 1963, ou as referências internacionais consagradas da arquitetura e design modernos, como a Bauhaus e a HfG de $\mathrm{Ulm}^{123}$.

E paralelamente a esse debate, a revista também abria espaço para artigos explicativos dos produtos industrializados de empresas brasileiras de construção ${ }^{124}$, como lajes pré-fabricadas e blocos de concreto, quando se discutia inclusive a ideia de casas modulares em alvenaria com lajes produzidas a partir de vigotas pré-fabricadas em concreto, ou se veiculavam propagandas

118 Problema remoto: o da moda. Habitat. São Paulo, n. 9, p. 65, out-dez. 1952; e SAMBONET, Luiza. Uma moda brasileira. Habitat. São Paulo, n. 9, p. 66-85, out-dez. 1952.

119 Artezanato e indústria. Habitat. São Paulo, n. 9, p. 86-87, out-dez. 1952.

120 Desenho industrial. Habitat. São Paulo, n. 02, p. 94, mar. 1951. Seção Alencastro; RUCHTI, Jacob. Instituto de Arte Contemporânea. Habitat. São Paulo, n. 03, p. 62-65, 1951.

121 Sobre o período em que Lina atuou como docente de Composição Decorativa na FAUUSP (FERRAZ, Geraldo. Habitat inicia um levantamento sobre as condições do ensino universitário em exposições feitas pelos responsáveis das diversas cadeiras da FAU. Habitat. São Paulo, n. 26, p. 5, jan. 1956); e sobre a atuação de Rino Levi como docente de Grandes Composições na FAUUSP e sobre as primeiras propostas para reformulação do currículo da graduação em Arquitetura e Urbanismo (Habitat prossegue no levantamento sobre as condições de ensino universitário em exposições feitas pelos responsáveis das diversas cadeiras de FAU. Habitat. São Paulo, São Paulo, n. 27, p. 47, fev. 1956).

122 Escola de desenho industrial. Habitat. São Paulo, n. 72, p. 59-60, jun. 1963.

123 Sobre nova educação diante dos problemas da automatização. Habitat. São Paulo, n. 34, p. 60, set. 1956.

124 Vários artigos: 1) As lajes pré-fabricadas. Habitat. São Paulo, n. 29, p. 65, abr. 1956; 2) Uma indústria que acompanha o esforço criador da moderna arquitetura brasileira. Habitat. São Paulo, n. 37, p 88-90, dez. 1956; 3) LANG, Alberto. Blocos de concreto vibrado e casas modulares. Habitat. São Paulo, n. 65, set? 1961. 
de componentes industrializados, como louças cerâmicas, lajes pré-fabricadas e perfis e chapas de alumínio ${ }^{125}$.

\section{O Dirigente Gonstrutor}

Em O Dirigente Construtor a quantidade de publicidade é bem maior que em Habitat ou mesmo em Acrópole. Até mesmo nos artigos sobre projetos, novas técnicas e tecnologias havia indiretamente a divulgação de uma empresa, uma vez que se tratava de uma revista de distribuição gratuita. Publicada pela Editora Visão ${ }^{126}$, O Dirigente Construtor estava no rol de revistas estrangeiras que entraram no mercado editorial brasileiro sob pretextos meramente técnicos e imparciais ${ }^{127}$, mas com a missão de convencer principalmente o terceiro mundo a aceitar passivamente a presença e interferência norte-americana na política e economia local.

Muita era a publicidade de produtos locais, como elementos vazados cerâmicos, painéis e placas de forro e vedação pré-fabricados de vários materiais, kits hidráulicos e elétricos, metais e cerâmicas sanitários e, principalmente, produtos de concreto, como os blocos para alvenaria estrutural da REAGO ${ }^{128}$ e da BESSER, as lajes pré-fabricadas VOLTERRANA - quiçá o produto mais divulgado em todas as revistas analisadas - e as empresas de construção industrializada em concreto, como a CINASA.

Augusto Carlos de Vasconcelos (2002, pag. 34-37) conta a história da CINASA, Construção Industrializada Nacional SA, fundada em 1965 a reboque da confiança que muitas

125 A lista completa dos anunciantes da revista Habitat pode ser encontrada em LEON, 2006.

126 A Editora Visão era o braço brasileiro do grupo editorial norte-americano Vision Inc. que, além de publicar no Brasil a revista "Visão" desde 1952, passou a publicar durante os anos 1960 também O Dirigente Construtor, O Dirigente Industrial e O Dirigente Rural, série de revistas técnicas que inauguraram o sistema de circulação controlada, isto é, gratuitas mas acessíveis apenas a profissionais qualificados. Sobreviviam provavelmente da publicidade em seu interior. Conforme SEVERO (2013), a entrada da Editora Visão no mercado editorial brasileiro fez parte da política pós-guerra norte-americana de controle da informação para formar a opinião pública, dominar o comércio mundial e as principais fontes de matéria prima. Em 1972, a editora brasileira foi comprada por Said Abrahim Farhat, seu então diretor comercial, que logo em 1974 a vendeu para Henri Maksoud, proprietário da Hidroservice. Em 1990, a editora foi vendida para o grupo DCI Shopping News e, por problemas financeiros, as publicações deixaram de circular em 1993. FONTE: SEVERO, Leandro. Uma breve história da luta da grande mídia contra os interesses nacionais. Agência Carta Maior. São Paulo, 16 de junho de 2013. Disponível em http://cartamaior.com.br/?/Editoria/Politica/Uma-breve-historiada-luta-da-grande-midia-contra-os-interesses-nacionais/4/28103. Consultado em 31 ago 2014.

127 Ver SEVERO, 2013.

128 Conforme Augusto Carlos de Vasconcelos (2002, pág. 97), a REAGO, fundada em 1965 com a função de produzir pedra britada, em 1967 passou também a produzir blocos de concreto a partir do pó de pedra extraído da pedreiras da Construções e Comércio Camargo Corrêa SA, da qual era subsidiária. Para a construção da Vila Operária da Usina Hidrelétrica de Ilha Solteira, a Camargo Corrêa importou prensas da empresa norte-americana BESSER para a produção de blocos para a montagem das habitações. Com a conclusão da cidade operária, para aproveitar o potencial das prensas que ficariam em desuso, a produção de blocos foi acrescentada à produção da REAGO. http://www.camargocorrea.com.br/grupo-camargocorrea/grupo/historia/historia-1960-1969.html 
construtoras depositaram no Plano Habitacional do BNH, acreditando que a industrialização das construções seria um negócio de sucesso num país em desenvolvimento. Apesar do constante repúdio do $\mathrm{BNH}$ à produção industrializada das habitações, a situação do país em 1965 era favorável e, com o apoio da Construtora Rabello, empresa que se desenvolveu na construção de Brasília e da obras do CEPLAN ${ }^{129}$, e seu proprietário, Marco Paulo Rabello, entusiasta da pré-fabricação de casas térreas, a CINASA foi instalada em São Bernardo do Campo com capacidade, já em 1966, para produzir 4 casas térreas por dia, além de outras construções, como escolas, fábricas, hospitais e prédios de apartamento.

No pátio da empresa eram expostos três modelos de residências térreas, desenvolvidos pela própria empresa e usados como mostruário, instalação para treinamento e aprimoramento dos componentes, e que atraíam muitos interessados. No entanto, os custos de manutenção da empresa eram altos, já completamente mecanizada à época, e os acabamentos de boa qualidade aplicados no produto final inviabilizavam a venda no varejo a preços competitivos.

Em 1967 surgiu a oportunidade da empresa finalmente convencer o Governo Federal a apoiar a produção industrializada de habitações, num evento emoldurado no imaginário da época: durante a coroação da Miss Distrito Federal, no Maracanãzinho, ao ser questionada sobre os três pedidos que faria ao Presidente da República, a vencedora Anísia Gasparina da Fonseca teria pedido uma casa para sua mãe morar. Marco Paulo Rabello telefona para o evento televisionado e oferece, ao vivo, uma casa da CINASA a ser entregue dentro de 5 meses, deixando a audiência estupefata com a oferta.

Apesar do sucesso da publicidade, a CINASA não recebeu o apoio que esperava receber das autoridades, que inclusive acompanharam o desenrolar dos fatos e estiveram presentes na entrega da edificação. Não muito tempo depois, antes do final da década de 1960, a empresa desativou sua seção de unidades habitacionais, tendo se voltado para a produção de grandes peças para a montagem de estruturas fabris.

Havia ainda muitas outras empresas de construção industrializada especialmente na região sudeste, criadas já durante a década de 1950, ou durante os anos 1960 por ocasião do PNH, como é o caso das seguintes, apresentadas por Vasconcelos (2002):

- ENGEFUSA - Engenharia de Fundações SA, criada em 1951 para prestar serviços de fundação e que ao longo do tempo foi diversificando sua produção até a préfabricação de moradias, aplicada na construção de inúmeros conjuntos residenciais no

129 Como se pode verificar na ficha técnica de várias obras do CEPLAN publicada na revista ACRÓPOLE, janeiro de 1970 - ANO 31 - No 36 
Rio de Janeiro até o final da década de 1960;

- Construtora OXFORD Ltda, que se desenvolveu durante sua participação na construção de Brasília e que, com a criação do $\mathrm{BNH}$, ingressou na produção de edificações industrializadas em concreto em 1964 utilizando os processos da patente francesa Estiot-Acier-Béton;

- PRECON Industrial SA, fundada em 1962 em Pedro Leopoldo, MG, pelo Engenheiro Milton Vianna Dias;

- PREMO, fundada em 1958, em Belo Horizonte;

- PROTENSA, inaugurada em 1963, única fundada por um arquiteto, René Marie Felix Mathieu, enquanto todas as outras aqui citadas foram empreendimentos de engenheiros. Sobre isso, Augusto Carlos de Vasconcelos comenta com sarcasmo que René Mathieu conhecia a pré-fabricação apesar de ser arquiteto.

- RODRIGUES LIMA Construtora Ltda, fundada em 1967 pelo Arquiteto Octacílio Rodrigues Lima;

- PROTENDIT - Fábrica de Pré-moldados de Concreto Protendido Ltda, fundada em 1958 pelo mesmo engenheiro Augusto Carlos de Vasconcelos que conta a história de tantas outras empresas do ramo fundadas entre as décadas de 1950 e 1960.

O texto de Augusto Carlos de Vasconcelos, no entanto, não deixa claro um conflito existente entre as empresas citadas acima, produtoras de grandes elementos pré-moldados, e as empresas produtoras de artefatos de cimento para o varejo. — Sinaprocim/Sinprocim ABCIC/ABECE, estas últimas consideradas de menor "importância" para as primeiras.

Uma dessas empresas produtoras de artefatos de cimento é a NEOREX, fundada em 1939, que por solicitação de Oswaldo Bratke inicia a produção de "caixilhos sem vidro", ou elementos vazados em concreto. Em seu sítio online ${ }^{130}$, a empresa indica que produziu e comercializou artefatos projetados por J.B.Vilanova Artigas e Rino Levi, entre outros profissionais. Com o tempo, a empresa foi diversificando seu catálogo, produzindo também outros produtos pré-moldados em concreto.

Além das empresas brasileiras, a ODC também apresentava na forma de artigo as tecnologias desenvolvidas à época por muitas empresas estrangeiras, ora instaladas no Brasil ora exportadoras de sua tecnologia para o Brasil. E, diferentemente das outras revistas, ODC 130 Disponível em http://www.neorex.com.br/sobre-neorex . O sítio online, no entanto, não aponta datas. 
apresentava as obras de arquitetura do ponto de vista do canteiro e de seus processos construtivos. Em ODG, a construção civil parece completamente diferente daquilo que era apresentado pelas outras revistas ou do que era criticado pelos arquitetos à época e hoje.

\section{Acrópole}

A revista Acrópole, desde a data de sua fundação em 1938, já está repleta de anúncios, o que talvez a classificasse num primeiro período como uma revista comercial (inclusive pelo caráter de divulgação dos serviços prestados pelos arquitetos, dado o tom em que eram apresentados os projetos) até que, num segundo período, um debate sobre o meio arquitetônico aparecesse com um tom mais profissional e maduro, mas já no fim de sua existência.

Tendo também um caráter bastante comercial, Acrópole apresenta produtos e processos patenteados em muitos de seus artigos, sem contar as páginas de publicidade direta. Nestas eram veiculadas propagandas das Janelas Ideal, as chapas de fibras prensadas da Duratex, as lajes pré-fabricadas da Volterrana e da Prel, os elementos pré-moldados em concreto da Neorex, as chapas em cimento amianto da Eternit e os pisos e revestimentos da Lagrart SA. Muitas dessas marcas estariam ainda anexadas aos artigos das obras onde foram empregadas, numa simbiose de credibilidade entre os projetistas e a marca, como as marcas Eternit, Mannesmann e Ribeiro Franco que aparecem junto do projeto do Conjunto Residencial da USP, onde foram de fato empregadas.

E de modo parecido com Habitat, Acrópole também divulgava as lojas "Ambiente" e "Preto e Branco" no mesmo meio social de seus proprietários. Até mesmo as obras e os arquitetos divulgados em Acrópole (como em Habitat) estariam circunscritos a um meio social quase fechado e exclusivo de arquitetos do eixo Rio - São Paulo ou, indo um pouco mais longe, de filiados ao IAB naqueles anos 1950 e 1960.

Na segunda metade da década de 1950, coincidindo com o período desenvolvimentista de Juscelino Kubitschek, seriam vários os artigos publicados sobre "arquitetura industrial" ou sobre "arquitetura e indústria", em que se apresentavam novos edifícios fabris instalados principalmente no eixo São Paulo - Rio ou São Paulo - Campinas. Tais artigos serviam também ao propósito de divulgar empresas e seus respectivos processos construtivos patenteados, quando então a pré-fabricação era, via de regra, abordada como solução construtiva óbvia. Várias empresas brasileiras de pré-fabricação teriam seus produtos e processos de pré-fabricação divulgados em Acrópole, como a empresa Edibrás, divulgando e 
detalhando tecnicamente, já em 1958, o método italiano Toschi ${ }^{131}$ para edifícios fabris, do qual era exclusiva representante no Brasil. Ou a Sociedade Tekno Ltda, que desenvolveu tanto estruturas leves em concreto como estruturas lamelares em madeira.

Em alguns desses projetos figurava a autoria de um ou mais arquitetos, como no caso da fábrica da Orniex ${ }^{132}$, projetada por Ney Marcondes e João de Gennaro e construída pela Louzada, Cavalcanti \& Cia Ltda; ou do arrojado projeto do Arq. Paulo Antunes Ribeiro ${ }^{133}$ para a sede da Gastal S.A - representante no Brasil da Willys Overland, produtora dos Jeeps, e da Hanomag, produtora alemã de tratores - instalada na Avenida Brasil no Rio de Janeiro.

Muitas vezes, no entanto, a proprietária da patente seria a responsável pelo projeto e construção da fábrica, como no caso da fábrica da GE, em Campinas, produzida pela Edimetal $^{134}$; dos armazéns da Pirelli S.A, construídos pela Edibrás ${ }^{135}$ segundo o método italiano Toschi, desenvolvida pelo engenheiro Luis Toschi; ou do edifício da Minnesota Manufatureira e Mercantil Ltda, de Campinas, projetada e construída pela Christiani-Nielsen Engenharia e Construtora S.A.

Em 1956, Acrópole dedica o número 209 à "Pré-fabricação" na tentativa de contribuir com o setor industrial da construção. Em seu editorial ${ }^{136}$, apelava para que os arquitetos indicassem os produtos industrializados em suas obras, “cujas vantagens são incontestáveis”. Os artigos ${ }^{137}$

131 Vários artigos: 1) MAZZOCCHI, Maurizio. A prefabricação nas construções industriais. Acrópole. São Paulo, n. 241, p. 25, nov. 1958; 2) Estrutura em concreto armado pré-fabricado. Acrópole. São Paulo, n. 241, p. 26-27, nov. 1958.

132 MARGONDES, Ney; DE GENNARO, João. Arquitetura industrial. Acrópole. São Paulo, n. 212, p. 312-315, mai. 1956.

133 RIBEIRO, Paulo Antunes. Arquitetura industrial no Rio de Janeiro. Acrópole. São Paulo, n. 219, p. 8385, jan. 1957.

134 Símbolo da nova era industrial brasileira - 6 meses para levantar as estruturas da fábrica GE em Campinas. Acrópole. São Paulo, n. 280, mar. 1962.

135 É de autoria de José Vicente Vicari, ainda docente na FAUUSP, o artigo sobre uma das fábricas da Pirelli: VICARI, José Vicente. A pré-fabricação na arquitetura industrial. Acrópole. São Paulo, n. 212, p. 319323, mai. 1956. Artigo sobre a segunda instalação da Pirelli: Arquitetura industrial. Acrópole. São Paulo, n. 218, dez. 1956.

136 Editorial. Acrópole. São Paulo, n. 209, fev. 1956.

137 Vários artigos: 1) COSTA, Flávio Dionysio de Andrade. Blocos de concreto vibrado. Acrópole. São Paulo, n. 209, p. 196-197, fev. 1956; 2) ZELATI, Aldo Coti. A construção e a pré-fabricação. Acrópole. São Paulo, n. 209, p. 185, fev. 1956; 3) ZELATI, Aldo Coti. Laje dupla em concreto. Acrópole. São Paulo, n. 209, p. 198-199, fev. 1956; 4) struturas leves de concreto armado pré-fabricadas. Acrópole. São Paulo, n. 209, p. 200201, fev. 1956; 5) Os blocos de concreto em São Paulo. Acrópole. São Paulo, n. 209, p. 202-203, fev. 1956; 6) Estudo teórico de lajes pré-fabricadas. Acrópole. São Paulo, n. 209, p. 204-205, fev. 1956; 7) Elementos vazados de concreto. Acrópole. São Paulo, n. 209, p. 206-207, fev. 1956; 8) Pavimentação articulada. Acrópole. São Paulo, n. 209, p. 208-209, fev. 1956; 9) LUCULESCU, Constantino. Construções com concreto armado supervibrado. Acrópole. São Paulo, n. 209, p. 210, fev. 1956; 10) LUGULESGU, Constantino. Lajes nervuradas com elementos múltiplos. Acrópole. São Paulo, n. 209, p. 211, fev. 1956; 11) Blocos de concreto "sistema trillor". Acrópole. São Paulo, n. 209, p. 212, fev. 1956; 12) ESCOREL, Fernando J. Tubos de concreto. Acrópole. São Paulo, n. 209, p. 213-215, fev. 1956. 
apresentavam, em maioria, produtos e processos construtivos em concreto ou argamassa, justificados pelo editorial e pelo engenheiro Aldo Coti Zelati ${ }^{138}$ por serem feitos a partir do cimento, o elemento cuja evolução científica possibilitou as audaciosas concepções de engenharia e arquitetura e que se converteu em expressão construtiva do homem moderno. E a pré-fabricação à base de cimento, de acordo com A.C. Zelati e com a revista, impunha-se cada vez mais como processo vantajoso por suas qualidades de economia de materiais, espaço e tempo, bastante adequado à nossa era.

A revista apresentou as vantagens do uso de blocos de concreto, tendo dado voz às empresas Blocos de "Concreto Blocima Ltda", "Construções e Comércio Camargo Corrêa S.A" (Blocos de Concreto Reago) e a "Gregório Francisco Gomes \& Cia Ltda"; do uso de lajes préfabricadas, tendo colaborado no artigo a empresa "Laje Forro-Novo Ltda" e a "Lajes Voterrana S.A. Indústria e Comércio"; as vantagens das estruturas leves em concreto armado pré-fabricado, sobre as quais falou a empresa "Sociedade Tekno Ltda"; dos elementos vazados em concreto, sobre os quais falou a "Silita Ltda."; da pavimentação articulada em concreto, sobre os quais falou a "Blokret Pavimentação Articuladas S.A". Mas os projetos de Sérgio Bernardes, Abelardo de Souza, Oswaldo Correia Gonçalves e Luis Saia apresentados no mesmo número não apontavam muito sobre os materiais utilizados nem sobre pré-fabricação.

A edição especial 209 de Acrópole não seria a única a tratar sobre o tema da industrialização: ainda em 1956, na edição $212^{139}$ Acrópole prosseguia numa campanha pela padronização dos métodos de construção; em 1962 o número 280 retornaria com o assunto da arquitetura industrial e com Teodoro Rosso discutindo o "imperativo inadiável" que se tornara a industrialização da arquitetura; e em 1965, dez anos depois, o próprio IAB voltaria ao assunto e lançaria o número 40 da revista Arquitetura, dedicado ao tema, publicando até mesmo a experiência de pré-fabricação em taipa em Cajueiro Seco, Pernambuco, relatada pelo arquiteto Acácio Borsoi.

Em vários números, desde sua fundação, era publicada a seção "Prancheta Viva" em formato de caderno ou catálogo de anunciantes. Já no final da década de 1960, pouco antes de ser encerrada, os anúncios da seção passaram a ser em menor quantidade mas muito mais específicos, onde eram apresentados com suas respectivas características de fabricação, detalhamento e informações técnicas para aplicação.

Eram apresentados painéis de madeira — o Eucaplac, da Eucatex, uma chapa dura de fibra

138 ZELATI, Aldo Coti. A construção e a pré-fabricação. Acrópole. São Paulo, n. 209, p. 185, fev. 1956.

139 Editorial. Acrópole. São Paulo, n. 212, p. 01, mai. 1956. 
de madeira, em vários tamanhos, revestida com pintura especial que podia ser usada como revestimento, lambril sobre estrutura de madeira ou alumínio e como divisórias; Painéis de vidro - o Veneglass, um caixilho duplamente envidraçado intercalado com uma persiana que podia ser usado como janela e como divisória de ambientes; Lajes pré-fabricadas em concreto - as lajes Volterrana, produzidas com vigotas pré-fabricadas em concreto e curadas a vapor, produzidas com a resistência e a largura solicitada pelo cliente; Painéis para forro - o Forrovid, painéis em fibra de vidro combinados com perfis de alumínio para a forração de tetos; Esquadrias de alumínio — as Janelas Soliramic, produzidas em perfis extrudados de alumínio, com acabamento anodizado no tamanho solicitado pelo cliente, recomendadas pela empresa para todos os tipos de edificação e que podiam ser instaladas sem a necessidade de mão-de-obra qualificada; Peças pré-fabricadas em concreto - a CINASA, que à esta altura já tinha voltado sua produção somente para elementos de grandes dimensões, pré-fabricados protendidos em concreto leve com argila expandida.

Eram divulgados produtos suficientes para compor uma edificação inteira. 


\section{Planos, habitação popular e industrialização nas revistas}

Outro assunto muito debatido pelas revistas seria a questão da habitação. Todas as revistas apresentariam artigos assinados, entrevistas ou editoriais sobre esse tema. E o tema não aparecia isolado: outros temas transversais eram debatidos aos mesmo tempo, tais como o $\mathrm{BNH}$ e o PNH e as críticas ou elogios a estes, vindos dos arquitetos e profissionais do meio; propostas em forma de projetos de habitações modulares, processos construtivos ou tecnologias eram apresentadas como milagrosas esperanças para a questão da habitação.

Além disso, as revistas também apresentam interessantes esforços promovidos pelas entidades patronais e pelas categorias profissionais junto ao BNH para modernizar a produção em massa de habitação popular.

\section{$\mathrm{O} \mathrm{BNH}$, o PNH e as críticas à produção em massa de habitação}

Em 1965, a política habitacional do país se baseava em duas medidas: no Plano de Habitação elaborado pelo $\mathrm{BNH}$ e na nova Lei de Inquilinato. A nova Lei do inquilinato ${ }^{140}$, tendo sido bastante combatida quando ainda era projeto, introduziu desequilíbrios na relação proprietário-inquilino em favor do primeiro. Acreditava o $\mathrm{BNH}$, na figura de sua Presidente a Sra. Sandra Cavalcanti, que a nova lei do inquilinato estaria estimulando ${ }^{141}$ os investimentos na produção de imóveis para aluguel, aumentando assim a oferta em relação à demanda, fato que não ocorreu. No caso do Plano Habitacional, este se baseava em estímulos à produção imobiliária para atender as classes médias, produção esta que contribuiria na forma de taxação compulsória para a produção de habitações populares, coisa que também não aconteceu. A meta inicial do BNH era zerar o déficit habitacional no país dentro de 4 anos.

Os arquitetos, principalmente os paulistas vinculados ao IAB-SP, participavam da discussão sobre a questão habitacional e iriam se pronunciar principalmente criticando o aspecto meramente financeiro do Plano de Habitação ${ }^{142}$. Os arquitetos e os técnicos da área também se sentiam frustrados, nas palavras de Jorge Wilheim ${ }^{143}$ — Diretor da Divisão de Urbanismo

\footnotetext{
140 Lei Federal 4.4494, de 25 de novembro de 1964. Regula a locação de Prédios Urbanos.

141 Carteira de redesconto é a chave do plano. O Dirigente Construtor. São Paulo, v. 1, n. 3, p. 74, jan. 1965. Entrevista.

142 Ainda o Plano Nacional de Habitação. Habitat. São Paulo, n. 76, p. 12, mar-abr. 1964. Editorial

143 Vários artigos: 1) Construir casas não resolve o problema habitacional. O Dirigente Construtor. São Paulo, v. 1, n. 4, p. 82, fev. 1965. Entrevista; 2) CORONA, Eduardo. Acerca da habitação popular. Acrópole. São Paulo, n. 319, p. 18, jul. 1965. Editorial. Eduardo Corona, acompanhando todo o debate sobre o problema habitacional brasileiro e o PNH, já em 1965 vai criticar todo o conjunto de milagrosas propostas para a questão:
} 
do IAB e membro da Comissão de Planejamento do IAB - pois suas contribuições ${ }^{144}$ eram recusadas pelo Governo Federal na resolução da questão habitacional. O governo federal teria vetado a contribuição do IAB apresentada durante debates parlamentares da matéria. Além disso, Jorge Wilheim afirmava - e não seria o único entre os arquitetos a ter esse entendimento - que a questão da habitação ultrapassava a mera produção de "tetos" e que fazia parte do conceito de habitação a criação de novas centralidades ou a boa localização dos projetos, a oferta de serviços de transporte, educação e saúde, além de infra-estrutura urbana, a despeito das cidades dormitórios nas periferias das médias e grandes cidades ou da ausência de financiamento de planos diretores para a implantação de conjuntos habitacionais.

Ao mesmo tempo, os arquitetos elogiavam as iniciativas pois acreditavam ainda assim que a política habitacional gerida pelo Banco estimularia a industrialização, a produção de casas pré-fabricadas e o mercado de materiais de construção. Até então, 1965, acreditavam também que a política habitacional de fato possibilitaria às faixas mais pobres da população acesso a habitações dignas justamente em razão da possibilidade de financiamento. No mesmo sentido, outros profissionais ${ }^{145}$ também fariam a crítica de que a mera construção de casas não resolveria o problema habitacional caso estas não ficassem integradas à cidade e não tivessem acesso aos serviços públicos essenciais, e recomendavam que o $\mathrm{BNH}$ somente aprovasse o financiamento de conjuntos habitacionais associados a projetos de expansão urbana com previsão de transporte público, integração com o núcleo da cidade, serviços urbanos e sociais essenciais e proximidades a centros comerciais.

Com o passar do tempo, a ausência de uma política habitacional genuína se tornaria evidente ante uma política de fato financeira. Oswaldo Correia Gonçalves, além de criticar a ausência de planejamento territorial nas esferas federal, estadual e municipal e a adequação dos financiamentos a renda familiar, criticaria ${ }^{146}$ ainda o desinteresse do Banco em estimular a industrialização da construção civil como ação para baixar o custo dos materiais de construção e a produção das unidades. Em 1969, o BNH lança o programa RECON ${ }^{147}$ -

pré-fabricação, moradia mínima, produção em escala, coordenação modular, se não houvesse planejamento nas várias esferas de governo e, mais que isso, se não houvesse uma maior preocupação com a edificação, seu tamanho (criticando as ideias de habitação mínima) e espaços agradáveis para as atividades cotidianas.

144 Vários artigos: 1) Problema da habitação no Brasil. Acrópole. São Paulo, n. 278, jan. 1962. Noticiário; 2) Plano Nacional de Habitação. Acrópole. São Paulo, n. 305, p. 21, abr. 1964. Notas; 3) Plano Nacional de Habitação. Acrópole. São Paulo, n. 306, mai. 1964. Notas

145 Em vários artigos: 1) Dispersão das habitações compromete a periferia urbana. O Dirigente Construtor. São paulo, v. 1, n. 10, p. 84, ago. 1965. Entrevista. 2) A marcha do PNH. O Dirigente Construtor. São Paulo, v. 2, n. 12, p. 9, out. 1966. Editorial.

146 Casa própria: existe um tripé na base do problema. O Dirigente Construtor. São Paulo, v. 4, n. 9, p. 70, jul. 1968. Entrevista.

147 RECON: operação para financiar materiais de construção. O Dirigente Construtor. São Paulo, v. 5, n. 
Refinanciamento ou Financiamento do Consumidor de Materiais de Construção, um subprograma do BNH, operado pelo Banco Brasileiro de Descontos S.A - Bradesco, cujos objetivos seriam, principalmente, reduzir o custo da construção ao aumentar o poder de barganha do consumidor final no balcão de compra e ampliar a oferta de materiais de construção no varejo através do financiamento da compra de materiais de construção no varejo pelo consumidor final. $\mathrm{O}$ que se depreende é que, diante da impossibilidade de atender às populações de mais baixa renda e diante também das críticas à ausência de estímulos à racionalização e industrialização da produção, o BNH teria partido para uma abordagem que incentivaria a autoconstrução, supondo que o aumento da demanda por materiais de construção no varejo obrigaria a racionalização e modernização das empresas transportadoras e produtoras de materiais de construção. Estava, na verdade, abandonando de vez as populações de mais baixa renda a resolverem sozinhas o problema da moradia.

O que na verdade estava sendo criticado pelos arquitetos, nas revistas, era o modelo de financiamento das unidades que privilegiava aquelas populações que justamente percebiam melhores salários, a ausência de planejamento urbano e a ausência de estímulo à racionalização e modernização dos projetos e do canteiro de obras. E era em relação a esses temas que a industrialização aparecia nos debates sobre a produção de habitação popular e sobre déficit habitacional nas revistas analisadas.

$\mathrm{O}$ BNH era considerada à época a maior experiência no campo habitacional no planeta tendo recebido, em 1970, a visita e os elogios neste sentido do Federal Home Loan Bank (EUA) e da USAID ${ }^{148}$. Seus defensores consideravam que o BNH havia garantido a criação de novos empregos e a redução dos custos da habitação, entre outras vantagens e aspectos positivos.

\section{O GTH — Grupo Técnico da Habitação}

Não muito tempo depois da fundação do BNH, em 23 de dezembro de 1964, fundava-se em São Paulo o GTH - Grupo Técnico da Habitação, anteriormente chamado de Grupo 20, que se propunha a assessorar o BNH mediante o pagamento de uma taxa fixa ${ }^{149}$.

Foi composto pelos seguintes engenheiros, arquitetos, advogados e administradores, muitos dos quais fariam, no futuro, carreira política: Sr. Nelson Mendes Caldeira, Arq. Paulo

03, p. 79-80, jan. 1969. Administração e custos.

148 Julgamento do PNH. O Dirigente Construtor. São Paulo, v. 6, n. 11, p. 08, set. 1970. Notas.

149 Vários artigos: 1) Técnicos propõem assessoria ao BNH. O Dirigente Construtor. São Paulo, v.1, n. 6, p. 86, abr. 1965. Entrevista; 2) Grupo técnico de habitação. Acrópole. São Paulo, n. 313, p. 17, jan. 1965. Notas. 
Cipolatti, Arq. Vicente Ignatti, Arq. Garcia Pardo, Eng. Gregório Gadaian, Eng. José L.B.A Castanho, Eng. Roberto Paulo Richter, Eng. Celso Eduardo B. de Siqueira, Arq. Ney Marcondes, Arq. Arnaldo Furquim Paoliello, Eng. Nelson de Barros Camargo, Sr. Luís Eduardo Pereira Barreto, Arq. Paulo Ésper Pimenta, Eng. Augusto Cincinato de Almeida Lima, Eng. Herbert Duschenes, Sr. Antonio Ferreira Braga Filho, Eng. Adolfo Mello, Arq. João Clodomiro B. de Abreu, Sr. Oscar Machado, Eng. Kurt Rhinow.

O GTH teria as seguintes incumbências, entre outras atividades menores:

1. atender, examinar e triar as propostas encaminhas ao BNH por interessados;

2. realizar estudos específicos sobre planejamento sócio-econômico;

3. examinar projetos habitacionais;

4. analisar a qualidade de novos materiais e processos de construção; averiguar a capacidade da indústria de materiais em relação à demanda;

5. apresentar soluções técnico-jurídico-administrativa para quaisquer problemas eventuais;

6. realizar vistorias nas habitações construídas para verificar as exigências do BNH;

7. examinar e aprovar documentação imobiliária;

8. promover a atualização das posturas municipais em relação à habitação popular para facilitar seu acesso aos planos de financiamento do BNH.

\section{O GBC - Bouwcentrum, o Centro Brasileiro da Construção}

Em 1965, Sérgio Pileggi comenta durante uma entrevista ${ }^{150}$ à ODC a experiência européia ${ }^{151}$ na produção de habitação em massa no pós-guerra, obrigados a racionalizar a produção em vista do volume necessário de unidades e como essa experiência poderia servir de exemplo para os objetivos do Plano Habitacional brasileiro. O Brasil, em suas palavras, deveria empreender a análise de projetos, simplificação de detalhes, estandardização de elementos e materiais da mesma maneira como os países europeus o fizeram. Sérgio retornava então ao Brasil, depois de ter passado dois anos em Madri estudando os problemas habitacionais e também depois de ter frequentado alguns cursos oferecidos pelo Bouwcentrum da Holanda.

150 Arquiteto formado em 1962 pela Universidade Mackenzie e Pós-graduado em Low Cost Housing pelo Bouwcentrum de Rotterdam, em 1965.

151 Experiência estrangeira pode ajudar Plano de Habitação. O Dirigente Construtor. São Paulo, v. 1, n. 9, p. 74, jul. 1965. Entrevista. 
Por volta de julho de 1968, constituía-se então o CBC Bouwcentrum - Centro Brasileiro da Construção ${ }^{152}$, um organismo autônomo, de atuação nacional, resultado de um esforço conjunto entre FIESP-CIESP, BNH, IAB-SP e IE (Instituto de Engenharia de São Paulo), cujos objetivos eram o aprimoramento da indústria e do comércio da construção civil. $\mathrm{O}$ grupo de trabalho que definiu os objetivos e diretrizes do CBC teve Raphael Noschese na presidência, o Eng. Lauro de Barros Siciliano como diretor-executivo, o Eng. Roberto Paulo Richter como coordenador dos trabalhos de implantação do CBC, assessorados pelo Arq. Sérgio Pileggi, do IAB-SP, e pelo Eng. Ney Marcondes, do BNH.

Representando ainda cada instituição, a primeira composição do CBC-Bouwcentrum era a seguinte, além dos nomes já citados:

Pelo IAB-SP: Abelardo Gomes de Abreu (presidente), Arnaldo Paoliello, Alfredo Paesani, Jon Maitrejean, José Luís Fleury, Roberto Aflalo, Armando D'Arns;

Pelo BNH: Mário Trindade (presidente) Arq. Heitor Vignoli, Adv. Bartolomeu Bueno de Miranda (delegado regional em São Paulo), Luis Carlos Vieira da Fonseca e Rubens do Amaral Portela;

Pelo IE: Henry Macksoud (presidente), Teodoro Rosso, Paulo Lessa da Fonseca, Henrique Hirshfield, Luís Falcão Bauer, Isac Tecla, entre outros;

Pela FIESP-CIESP: Theobaldo de Nigris (presidente), Rubem de Mello, Lívio Meloni, José Polizoto, Carlos Hidalgo, Felipe Franceschini, Flávio Noschese, Luís Prestes Barra, Rubens Maragliano, Elion Maia e Mário de Toledo Novais.

A criação do CBC-Bouwcentrum era justificada pela atuação das instituições similares na Alemanha, na França e na Holanda, com importante atuação na reconstrução do pós-guerra. E funcionaria como fonte normativa para a indústria da construção civil, desde a produção de materiais até a tecnologia da construção. Eram objetivos do $\mathrm{CBC}^{153}$ :

1. promover a divulgação e aplicação de medidas e processos destinados a racionalizar a construção;

2. estimular o aprimoramento da indústria e comércio da construção; - organizar um centro de documentação da construção e habitação;

3. organizar amplo sistema de divulgação informação assessoramento e intercâmbio de 152 "Bouwcentrum": esforço para aprimorar a construção. O Dirigente Construtor. São Paulo, v. 4, n. 9, p. 49-52, jul. 1968. Administração e Custos.

153 Centro Brasileiro de Construção - Bouwcentrum. Acrópole. São Paulo, n. 350, p. 19, mai. 1968. 
informações relativas à construção;

4. estimular o aprimoramento da mão-de-obra e dos conhecimentos técnicos e profissionais vinculados à construção;

5. realizar estudos e pesquisas sobre a construção em geral, as edificações para fins específicos e, principalmente, as habitações.

O CBC se organizaria em três departamentos: Departamento de informação, divulgação e documentação; Departamento de economia e produtividade e um Departamento Técnico. Este último estava encarregado de realizar estudos sobre racionalização de métodos e industrialização, além de coordenar ensaios e convênios com laboratórios, expedir certificados de qualidade a materiais, implantar canteiros experimentais e promover cursos e seminários. A manutenção do $\mathrm{CBC}$-Bouwcentrum seria feita através de recursos provenientes do $\mathrm{BNH}$, durante o prazo de seus primeiros 60 meses de existência e a verba para a manutenção de despesas variáveis deveria provir das próprias atividades do CBC junto a terceiros, ou da captação de recursos junto a outras entidades visando sua autosuficiência.

Com um ano e meio de existência ${ }^{154}$, o CBC promovia um estudo detalhado sobre implantação da coordenação modular contratado pelo BNH em $19699^{155}$ — o "Plano de Implantação da Coordenação Modular" no Brasil - com a finalidade de baratear os custos da construção civil mediante a racionalização e padronização de produtos.

De 1946 até o fim da década de 1960, vários países desenvolvidos elaboraram e adotaram normas de coordenação modular.

No Brasil, apesar da primeira norma de Coordenação Modular, a NB-25R, ter sido publicada já em 1950, muitos profissionais ainda chamavam atenção para a falta de coordenação dimensional dos produtos disponíveis no mercado durante as décadas de 1950 e 1960. Seria só com a divulgação dos trabalhos elaborados dentro do Centro CIPHAB de São Paulo pelas revistas especializadas que as teorias sobre Coordenação Modular e outras ferramentas para o projeto racionalizado atingiriam um público maior. E já era maio de 1968 quando uma publicação com o peso de Acrópole divulgaria a teoria da modulação para o projeto arquitetônico $^{156}$.

Além disso, o CBC participava de eventos contribuindo com o debate sobre a necessidade de

154 Um ano e meio de atividades no Centro Brasileiro da Construção. O Dirigente Construtor. São Paulo, v. 6, n. 07, p. 126, mai. 1970. Entrevista.

155 CBC faz estudos para o BNH. Acrópole. São Paulo, n. 366, p. 11, out. 1969.

156 Teoria modular. Acrópole. São Paulo, n. 350, p. 22-23, mai. 1968. 
industrialização, como no $8^{\circ}$ Congresso Brasileiro de Arquitetos, cujo tema foi "As potencialidades do arquiteto frente ao desenvolvimento da sociedade atual", em que apresentou a tese "A Industrialização da Construção"no painel sobre "Indústria e Arquitetura" $" 157$.

Depois disso, talvez sua principal realização tenha sido o "Plano de Implantação da Coordenação Modular no Brasil" empreendido por Teodoro Rosso, entre outros profissionais, por solicitação do BNH, que o recusou quando foi entregue ${ }^{158}$, conforme Sant'Anna (1974).

Não foi possível, ainda, averiguar a data em que o CBC foi desativado, provavelmente por volta de 1977, último ano de publicação sua disponível na biblioteca da EESC-USP.

\section{Os GIPHAB - os Centros de Coordenação Industrial para o Plano Habitacional}

Antes da constituição do GBC-Bouwcentrum e da elaboração do "Plano de Implantação da Coordenação Modular", a FIESP-CIESP já teria um Centro de Coordenação Industrial para o Plano Habitacional - o CIPHAB, criado em $1966^{159}$, por meio do qual faria chamamentos públicos para estudos e pesquisas sobre temas ligados ao desenvolvimento da construção civil, numa provável tentativa de colaborar com as construtoras que atendiam o PNH, já que este seria o grande financiador de projetos para o mercado construtor à época. O centro teria a função de investigar os potenciais da indústria paulista e, entre outros assuntos, a coordenação modular, a capacidade produtiva no setor de materiais de construção, política de preços, planejamento de novas indústrias, estudo e pesquisa de novos materiais e novas técnicas de construção, planejamento para uma política nacional de fretes e transportes.

A criação dos Centros de Coordenação Industrial para o Plano Habitacional - CIPHAB foi incentivada pelo BNH junto às Federações das Indústrias de vários estados ${ }^{160}$. Até 1968, havia Centros CIPHAB em funcionamento nos estados de São Paulo, Rio Grande do Sul e Guanabara.

Em São Paulo, o Centro CIPHAB foi instituído em agosto de 1966 e, em dezembro do mesmo ano, firmou convênio com o BNH. Era composto por 15 representantes das áreas industriais relacionadas a construção civil, mais os presidentes de 22 sindicatos de indústrias do mesmo

157 Indústria e Arquitetura IN: Congresso Brasileiro de Arquitetos, 8º 1969. Anais. Porto Alegre: IAB, 1969.

158 SANT'ANNA Jr, Antonio Carlos. Subdesenvolvimento: urbanização e industrialização da construção. TGI FAUUSP. São Paulo, 1974. Orientação de Paulo J.V. Bruna.

159 A Federação das Indústrias do Estado de São Paulo pretende constituir um centro de coordenação. O Dirigente Construtor. São Paulo, v. 2, n. 11, p. 61, set. 1966. Entidades e dirigentes.

160 Indústria e o Plano Habitacional. Acrópole. São Paulo, n. 350, p. 18, mai. 1968. 
setor, resultando na seguinte composição à época de sua fundação:

Presidente: Raphael Noschese. Coordenador: Roberto Paulo Richter. Membros: Luiz Prestes Barra, João Soares Amaral Netto, Lívio Melone, Victor Geraldo Simonsen, José Ermírio de Moraes Filho, Gildo Paretti, José Polizotto, Ruben de Mello, Sérgio Roberto Ugolini, Flávio Antonio Noschese, Álvaro Bovolenta e Atílio Tinucci. E sua função era:

1. Assessorar a Presidência da FIESP-CIESP sobre os problemas ligados aos Plano Habitacional;

2. Coordenar as pesquisas e trabalhos técnicos para efeito de subsistir a política habitacional do Governo Federal;

3. Desenvolver o Projeto-Empresa do Banco Nacional da Habitação;

4. Coordenar as atividades necessárias à ampliação das atuais indústrias, e fomentar a instalação de novas empresas relacionadas com o Plano Habitacional;

5. Orientar, de um modo geral, as indústrias, nas relações com o BNH e demais órgãos governamentais.

Em 1966, seria lançado um edital ${ }^{161}$ para habilitação de firmas interessadas em trabalhos técnicos profissionais, cuja concorrência foi vencida em 1967 pelo GTH (Grupo Técnico da Habitação). O resultado do trabalho foi o Estudo $\mathrm{n}^{\circ} 10^{162}$, sobre os seguintes temas de pesquisa:

1. Coordenação Modular;

2. Pesquisa de Materiais de Construção;

3. Nova Política de transportes aplicável no Plano Habitacional;

4. Serviços Relacionados com as instalações elétricas e hidráulicas aplicadas às construções industrializadas;

5. Produção e consumo do cimento.

Cada um dos temas, elaborado por uma equipe técnica, é descrito brevemente abaixo. O mais interessante é notar como os mesmos profissionais apontados abaixo circulavam no meio de GTH, CIPHAB, Bouwcentrum, Instituto de Engenharia e IAB-SP.

161 Plano habitacional. Acrópole. São Paulo, n. 335, p. 19, dez. 1966. Notas.

162 Estudo n.10. Relatório da coordenação industrial para o plano habitacional (GIPHAB). Sem local: GTH-BNH, 1967. 
Tema 1 - Coordenação modular, elaborado pelos arquitetos João Clodomiro B. de Abreu, Luiz Garcia Pardo, Ney de Carvalho Macondes, Sérgio Ferraz Gontijo de Carvalho, Sérgio Suñe Pileggi, e Vicente Ignati. Dentro desse tema e dos objetivos que, via de regra, se estabelecem para a normatização de um setor produtivo, o estudo foi elaborado a partir do levantamento das principais indústrias de materiais de construção de São Paulo e do país; depois, o estudo organizou os estudos normativos realizados e implantados já no setor; e em seguida, foram propostos sistemas de coordenação modular adequado à realidade brasileira, como a coordenação modular aplicada à construção de alvenarias com blocos padronizados.

Tema 2 - Nova política de transportes aplicável ao Plano Habitacional, elaborado pelos engenheiros Cássio Penteado Serra, Frederico de Assis Pacheco Borba, J.M. Kornbluh e Lauro de Barros Siciliano. Dentro de uma perspectiva de facilitar e baratear o transporte dos materiais de construção e averiguar novas possibilidade de transporte, o trabalho apresenta um estudo comparativo de custos entre as várias modalidades de transporte existentes no Brasil. E depois de estimar as demandas por materiais nos projetos residenciais e verificar a localização dos centros produtores de materiais, a equipe técnica elaborou uma recomendação sobre os meios de transportes mais adequados a cada um dos centros tendo em vista a redução de custos.

Tema 3 - Serviços relacionados com as instalações elétrica e hidráulicas aplicadas às construções industrializadas, elaborado pelos engenheiros Oscar Guimarães Machado e Homero Vieira de Mello Lopes. Tendo como perspectiva a industrialização das construções, o estudo tinha por objetivo a racionalização, o barateamento e a facilidade de execução das instalações industrializadas. Foram elaborados estudos de instalações prediais pré-fabricados para casas tanto também pré-fabricadas como moduladas convencionais, quando se constatou que as instalações convencionais podem ser até 36\% mais caras e demoradas que as préfabricadas.

Tema 4 - Produção e consumo de cimento - subsídios preliminares para uma nova política para o cimento no Brasil, elaborado pelos engenheiros João Soares do Amaral Neto, Luiz Alfredo Falcão Bauer e Nelson de Barros Camargo. O estudo buscou estimar a necessidade intensiva do material nas diversas fases da construção para então estimar também as demanda atual e futura de cimento. $\mathrm{O}$ estudo ainda especulou outros tipos de materiais aglomerantes que pudessem substituir o cimento e apresentou recomendações de ordem produtiva, logística e tributária para o setor cimenteiro. À época, o Brasil estimava passar por uma escassez de 
cimento o que obrigaria importação do produto, e o trabalho chamava atenção para esse ponto, já que o Brasil possui as matéria-prima do cimento em abundância.

Tema 5 - Pesquisa de Materiais de Construção, elaborado pelos engenheiros Augusto Cincinato de Almeida Lima, Gregório Gadaian, Teodoro Rosso e pelo economista Enio Squassoni. O estudo considerou tanto a produção de materiais para a construção convencional de habitações quanto a produção pré-fabricada. No primeiro, realizou um levantamento amostral das principais empresas produtoras de materiais de construção no Brasil para então (1) analisar as condições gerais de funcionamento do parque produtivo, destacando seus principais problemas, (2) levantar dados sobre a capacidade produtiva e a existência de capacidade ociosa para dar conta das necessidade do PNH e (3) levantar detalhes da fabricação sobre produtos, normas atendidas e a existência de linhas populares de produtos. No segundo estudo, analisou os 3 tipos de pré-fabricação (total, de série aberta e a parcial) a partir do levantamento amostral dos principais fabricantes de (1) blocos de concreto, (2) estruturas de concreto industrializadas, (3) lajes pré-fabricadas, (4) painéis de vedação de tipos diversos, (5) processos de industrialização total e parcial e (6) forros. No mesmo trabalho, a equipe cita os tipos de construção de habitação existentes no país à época: casas de alvenaria, casa-pacote e casas pré-fabricadas. Cita o preconceito que se tem no Brasil contra as casas pré-fabricadas, que têm aspecto mal acabado, pouco resistente e de rápida depreciação; mas em seguida aponta como isso é infundado, citando a aplicação da pré-

fabricação de residências nos EUA e Europa. E aponta a 3 empresas que produzem casas pré-fabricadas no Brasil: Planesa - Companhia de Planejamento da Habitação, em SBC; CINASA - Construção Industrializada Nacional SA, SBC; USITEC - Usina Técnica de Concretagem Ltda, São Paulo.

Uma das conclusões do trabalho apontou o desconhecimento das empresas em relação à coordenação modular. O Estudo n ${ }^{\circ} 10$ tecia então a recomendação de ser incluída no currículo dos cursos de Materiais para Construção o ensino da Coordenação Modular, entre outras. Ao final, o documento sugere a definitiva instalação do CBC-Bouwcentrum - que talvez já estivesse em gestação - e que poderia trazer benefícios ao andamento do PNH.

\section{O Catálogo Brasileiro da Construção, do IAB}

CBC era também a sigla do Catálogo Brasileiro da Construção, lançado pelo IAB em 1961 com o nome inicial de Catálogo Geral da Indústria de Construção e que, a partir de 1962, 
assume o nome de CBC. Conforme depoimento, Jon A.V. Maitrejean ${ }^{163}$ acessava já no fim dos anos 1950 o Sweet's Catalog ${ }^{164}$ — um catálogo norte americano de produtos de arquitetura, interiores e construção civil distribuído para os profissionais da área desde $1906^{165}$ — de onde tirou a ideia sugerida a Teodoro Rosso, que aceitou com entusiasmo: produzir uma publicação que condensasse o maior número de fabricantes brasileiros possíveis para facilitar a vida dos projetistas.

E o que era o Sweet's Catalog? A produção de "catálogos de venda" é um fenômeno que surgiu com a Revolução Industrial (Frank Matero in ROSS ${ }^{166}$, 1989). Conforme cresceu a atividade industrial nos EUA principalmente após a Guerra Civil, várias empresas de construção civil, entre outras, passaram a produzir catálogos cada vez mais sofisticados, incentivados também pela crescente atividade de expansão de cidades e construção de edifícios altos, que foram despejados aos milhares para os arquitetos e construtores à época. Clinton W. Sweet (1842 - 1917), empresário da construção civil, jornalista de arquitetura e de mercado imobiliário, resolveu organizar e sistematizar a literatura comercial da construção civil através de uma só publicação, como um dicionário. Em 1906, sua editora Architectural Record Company reuniu os catálogos de todas as empresas atuantes nos EUA no Sweet's Catalog. Em 1912, os direitos de publicação foram vendidos para a F.W. Dodge Company. Desde então, passou por várias editoras e teve seu nome alterado várias vezes.

Já a primeira edição do Sweet's Catalog era composta por aproximadamente 840 páginas, com uma coleção bastante abrangente dos produtos e fabricantes existentes à época. Com o tempo, foi sendo aprimorado não somente em relação aos produtos que eram acrescentados, mas também em relação ao seu projeto gráfico. Em meados da década de 1930, Knud Lönberg-Holm - um arquiteto dinamarquês que se formou entre os construtivistas e o movimento De Stijl, emigrado para os Estados Unidos em 1924 - tornou-se diretor do Departamento de Pesquisa da F.W. Dodge Company e promoveu uma revolução silenciosa (ou uma segunda revolução comparada com a primeira, a própria publicação do Sweet's Catalog) com a introdução de recursos gráficos para melhorar a legibilidade e a síntese das informações contidas em cada catálogo de produto e fabricante ${ }^{167}$, incluindo as teorias e os sistemas

163 Entrevista concedida em 12 de setembro de 2015.

164 A história do Sweet's Catalog desde sua inauguração em 1906 até 1947 é contada por SHANKEN (2005). Hoje, o Sweet's Catalog pode ser encontrado no sítio online: http://sweets.construction.com

165 SWEET'S, 1906.

166 ROSS, Norman (org). Guide to Architectural Trade Catalogues from Avery Library, Columbia University. Introduction by Frank Matero. Frederick: UPA Academic Editions, 1989. Acessado em 09 de outubro de 2015. Disponível em http:/ / cisupa.proquest.com/ksc assets/catalog/846.pdf.

167 SHANKEN, 2005, pág. 12. 
gráficos de pictogramas ${ }^{168}$, combinados a estratégias de publicidade. Cada página era projetada uma a uma pela própria editora, por uma equipe de arquitetos e designers coordenados por Holm, que transformou um compilado de catálogos de aparência vulgar em uma publicação com páginas de publicidade icônica. Shanken (2005) comenta sobre como o Sweet's Catalog cuidou da ideia da eficiência, tão em voga no começo do século XX e representou uma experiência de taylorizar a informação para taylorizar a construção.

Já o CBC, aqui no Brasil, foi publicado pela Editora e Consultoria Industrial CINC Ltda e organizado e orientado pelo IAB - Departamento de São Paulo, onde circulava Jon Maitrejean, com o apoio do Instituto de Engenharia, por sua vez onde circulava Teodoro Rosso. Era distribuído gratuita e anualmente para todos os arquitetos do Brasil, provavelmente às custas dos anunciantes.

$\mathrm{Na}$ abertura do segundo volume ${ }^{169}$, o IAB apresentava seu entendimento sobre o CBC ser a possibilidade do entrosamento com a indústria tão procurado pelos arquitetos, e incentivava um debate em que os arquitetos, por um lado, devessem expor as necessidades existentes sobre os materiais de construção e sobre as possibilidades de pré-fabricação e, na outra mão, os industriais devessem expor os problemas específicos sobre como atender a enorme demanda da construção civil. Parecia ser intenção do organizador que os arquitetos entrassem em contato com os fabricantes ao menos para tirar dúvida técnica sobre os produtos, já que a publicação trazia não só um encarte de cartões postais, mas apontava os vários endereços de contato disponíveis de todas as empresas anunciantes - fábrica, escritório, showroom, etc.

O catálogo era organizado em dezoito secções, que apresentavam desde equipamentos de escritório, produtos para serviços preliminares e equipamentos de obra passando pelos vários sistemas construtivos até elevadores, equipamentos especiais, decoração e produtos para jardins e piscinas. E cada empresa e o tipo de produto anunciados eram organizados em índices remissivos. Na secção "Decoração" eram anunciados produtos residenciais da loja Ambiente, Mobilínea, da L'Atelier e da Oca, além de móveis para escritórios, tapetes, móveis planejados para cozinha e armários embutidos.

Desde sua publicação inaugural já incluía tabelas de honorários de serviços de arquitetura para consulta. A partir de 1965, o CBC passou a incluir "tabelas, ábacos e gráficos de normas

168 Na verdade, isotypes - International System of Typographic Picture Education — desenvolvidos pelo filósofo da Escola de Vienna, Otto Neurath.

169 CATÁLOGO Brasileiro da Construção. São Paulo: IAB-SP/ Editora e Consultoria Industrial CINC, 1962. 
técnicas" ${ }^{170}$ para facilitar a consulta pelos seus assinantes, além de projetos de normas para que os mesmos arquitetos que consultavam o catálogo pudessem participar da elaboração das mesmas.

Numa breve análise visual, parece que a publicação é o simples agrupamento de catálogos produzidos por seus respectivos fabricantes, sugerindo a inexistência de um projeto gráfico elaborado pela editora ou pelo IAB à maneira dos projetos gráficos elaborados para o Sweet's Catalog.

À época do lançamento da publicação, a formação do Departamento de São Paulo do IAB era a seguinte ${ }^{171}$ :

Presidente: Oswaldo Corrêa Gonçalves; Vice-Presidente: Fábio Moura Penteado; $1^{\circ}$ Secretário: Brenno Cyrino Nogueira; $2^{\circ}$ Secretário: Jorge Wilheim; $1^{\circ}$ Tesoureiro: Carlos Barjas Millan; $2^{\circ}$ Tesoureiro: Paulo Mendes da Rocha; Diretores: Alfredo S. Paesani, Joaquim Guedes, Léo Ribeiro de Moraes, Bernardo Castelo Branco, Guaracy Moreira Pimentel e Marlene Picarelli.

Na Assembléia Nacional, o Departamento de São Paulo do IAB era representado pelos seguintes delegados: Rino Levi, Rubens Carneiro Viana, Alberto Rubens Botti, Luis Saia, Mauricio Tuck Schneider e Heitor Ferreira de Souza; e pelos seguintes suplentes: José maria Gandolfi, Telesforo Cristofani, Umberto Aveniente, Paulo Bastos, João Cacciola e João Batista Alves Xavier.

No Conselho Superior, o Departamento de São Paulo do IAB era representado pelos seguintes delegados: Oswaldo Corrêa Gonçalves, Ícaro de Castro Mello, João Batista Vilanova Artigas, Eduardo Kneese de Mello; e pelos suplentes: Eduardo Corona, Pedro Paulo de Mello Saraiva e Anibal Martins Glemente.

Vários desses representantes já eram docentes da FAUUSP à época ou o seriam em breve. E parece incrível que o próprio IAB tivesse organizado uma publicação como aquela, recheada de produtos industrializados aparentemente corriqueiros da atividade de construção.

Ao que tudo indica, o CBC foi publicado somente durante a década de 1960 no Brasil. Mesmo assim, o CBC deve ter tido tal importância que mereceu até um selo postal comemorativo. E na revista Acrópole, o IAB anunciava aos arquitetos que renovassem o

170 CATÁlOGO Brasileiro da Construção. São Paulo: IAB-SP/ Editora e Consultoria Industrial GINC, 1965.

171 Composição do IAB apresentado no CATÁLOGO Brasileiro da Construção. São Paulo: IAB-SP/ Editora e Consultoria Industrial CINC, 1962. 
catálogo anualmente ${ }^{172}$, devolvendo a edição anterior.

Ainda fazemos uma última observação sobre os catálogos: Shanken (2005) comenta sobre como a cultura do consumo poderia parecer estarrecedora para os arquitetos do final do século XIX que, ainda resistindo na tradição das Belas-Artes, tentavam conciliar bravamente a necessidade de fazer negócio com suas aspirações à alta cultura. Shanken argumenta que a ética das profissões liberais, que proíbe ou não costuma ver com bons olhos a prática da autopromoção de serviços, pode ainda ter influenciado muitos arquitetos a olhar com antipatia qualquer tipo de publicidade. Há também o fato do arquiteto, tendo conhecimento técnico superior, não se deixar levar pelas palavras animadas do publicitário ou do vendedor. Para Shanken o arquiteto é um tipo muito particular de "homem de negócios" pois, mesmo lidando com atividades artísticas e de criação, também exerce papel de gerente da obra que produz, administrando um montante de dinheiro relativamente alto para concretizar a obra, e compara os arquitetos aos médicos em relação ao conflito ético de receitar remédios: o arquiteto, da mesma maneira, lidaria com um conflito ético em indicar produtos industrializados. 


\section{Referências de arquitetura nacional e internacional industrializadas}

Além dos temas apontados anteriormente, as revistas veiculavam muitas referências de obras produzidas no período - tanto nacionais quanto internacionais - cuja solução industrializada ou mecanizada possibilitou ora uma produção de unidades em larga escala ora uma produção em curto espaço de tempo, ora ambos.

Ainda que sutilmente, as obras eram apresentadas com um tom de milagrosas esperanças para a solução do déficit habitacional brasileiro. Esse era um dos jeitos como a industrialização, a mecanização e a produção em massa eram abordadas ou formavam o repertório do imaginário da época.

Até algumas empresas que importavam patentes européias desenvolvidas para a reconstrução e profissionais ligados a estas iriam escrever nas revistas relatando sua experiência e trazendo tais referências para cá. Maurício Mazzocchi, que em 1958 iria divulgar na revista Acrópole ${ }^{173}$ os produtos da patente italiana Toschi para a Edibrás, já em 1956 escrevia para Habitat sobre a reconstrução europeia ${ }^{174}$ e como essas experiências poderiam servir de exemplo para a produção de habitação em locais atingidos ou não pela guerra. Em seu artigo, Mazzocchi discute as especificidades da produção escandinava e suiça, os projetos para unidades sanitárias até questões técnicas de produção industrializada, trazendo imagens da montagem de edifícios e de blocos técnicos hidráulicos.

Habitat também faria referência às obras norte-americanas de Mies van der Rohe para o Illinois Institute of Technologies (ITT) ${ }^{175}$, entre outras, cujos edifícios produzidos em aço e vidro são fortes imagens de progresso técnico e fazem alusão à canteiros de obra avançados e mecanizados.

Nacionalmente, no final dos anos 1960, as revistas já estariam repletas de obras que ou importavam tecnologia estrangeira ou tentavam reproduzir as referências estrangeiras, como a Comprector - Construtora e Industrial Ltda, onde também atuava o arquiteto Otacílio

173 Sobre isso fizemos um comentário sobre a publicidade de produtos brasileiros no item "Acrópole", neste capítulo. MAZZOCGHI, Maurizio. A prefabricação nas construções industriais. Acrópole. São Paulo, n. 241, p. 25, nov. 1958

174 MAZZOCGHI, Maurício. A casa, sua construção e sua industrialização. Habitat. São Paulo, n. 29, p. 33-36, abr. 1956

175 KULTERMANN, Udo. O clássico L. Mies van der Rohe e os "miesianos". Habitat. São Paulo, n. 43, p. 17-26, jul-ago. 1957 
Rodrigues Lima, proprietário da Rodrigues Lima Ltda — que produzia painéis ${ }^{176}$ similares aos "grand paineis" da reconstrução européia e os aplicava na construção de escola ou a Lopes da Costa Engenharia S.A, que desenvolveu processo para moldagem de grandes painéis de concreto ao pé da obra ${ }^{177}$. E havia artigos que mencionavam o projeto para a nova sede da Secretaria de Agricultura ${ }^{178}$ do Estado de São Paulo ou para escolas públicas ${ }^{179}$ da cidade de São Paulo.

Mas, talvez a mais significativa dessas obras apresentadas pelas revistas, cujo projeto data ainda de 1961, é o Conjunto Residencial da Universidade de São Paulo (CRUSP) — de autoria de Eduardo Kneese de Melo e Sidney de Oliveira, premiado com a Grande Medalha de Ouro no $12^{\circ}$ Salão Paulista de Arte Moderna ${ }^{180}$ — apresentado já no número inaugural de $\mathrm{ODC}^{181}$ e que inclusive dialogava com a produção estrangeira e com o imaginário sobre a industrialização para docentes da FAUUSP. O artigo trazia detalhes sobre seu canteiro de obras - onde se utilizou uma grua apoiada em trilhos que corriam também em duas direções horizontais para transportar os painéis e os elementos pré-fabricados - e análise da Ribeiro Franco S.A, responsável pela execução da obra, sobre a viabilidade econômica da préfabricação naquela obra que, mesmo não tendo sido atingida pela baixa repetição de componentes e de formas, funcionou como um ensaio para a aplicação da técnica.

Ainda na revista ODG eram comuns os artigos sobre novas tecnologias para construção de habitação em tempo recorde:

- ECEL - Escritório de Engenharia e Construções, de São Paulo — testava em 1965 casas de 70m2 montadas em 10 dias com perfis metálicos leves e chapas de fibrocimento ${ }^{182}$

176 Pré-moldagem atende a uma nova arquitetura do ensino. O Dirigente Construtor. São Paulo, v. 5, n. 04, p. 23-27, fev. 1969. Técnicas e materiais.

177 Pré-fabricação de canteiro: cada qual com seu sistema. O Dirigente Construtor. São Paulo, v. 4, n. 10, p. 37-42, ago. 1968. Técnicas e materiais.

178 MARTinO, A.A; BERGAmin, A; CASTRO, J.G.S; BRUNA, P; BUENO Filho, J; BIASI, A.M; TAALAT, A; TAYATA, M.A. Acrópole. Concurso para secretaria de Agricultura — lo prêmio. São Paulo, n. 357, p. 18-21, dez. 1968.

179 XAVIER, J.B.A; COSTA, L.C; GRESTANA, F.V. Pré-fabricação para edifícios escolares. Acrópole. São Paulo, n. 360, p. 30-33, abr. 1969.

LOTUFO, Z; PINI, U; SGANZERLA, G; LOTUFO, V. Escola técnica federal de São Paulo. Acrópole. São Paulo, n. 363, p. 38-41, jul. 1969.

180 Setor residencial da Cidade Universitária. Acrópole. São Paulo, n. 303, p. 93-101, fev. 1964

181 Pré-moldados de concreto compensam para estruturas em série. O dirigente construtor. São Paulo, v. 1, n.1, p. 46-52, nov. 1964. Técnicas e Materiais.

182 Casa de fibrocimento pode ser montada em 10 dias. O Dirigente Construtor. São Paulo, v. 1, n. 7, mai. 1965. Técnicas e Materiais. 
- a empresa USITEG - Usina Técnica de Concretagem Ltda, de São Paulo - que patenteou, também em 1965, painéis nervurados de concreto para montagem de casas de $45 \mathrm{~m} 2$ em 8 horas $^{183}$;

- a Lely do Brasil S.A. Indústria e Comércio que estudava introduzir no Brasil a produção dos blocos técnicos ${ }^{184}$ desenvolvidos por sua matriz - a C. van der Lely N.V, da Holanda - para a produção de habitação popular no padrão exigido pelo BNH e que podiam ser montadas no terreno final em apenas 3 horas por 6 operários;

- a CINASA, dessa vez com um artigo técnico ${ }^{185}$ que descrevia seu processo de produção de 10 casas por dia em grandes painéis de concreto com argila expandida.

- a TIGRE ${ }^{186}$ — à época, da Companhia Hansen Industrial, de Joinville, Santa Catarina - com publicidade sobre painéis hidráulicos e elétricos

Em 1966, a Engefusa (do antigo Estado da Guanabara) adotaria a patente Barets (patente que consistia basicamente de grandes painéis de concreto para laje e vedação moldados em fábrica e montados no canteiro com o auxílio de gruas) para a construção do Conjunto Padre José de Anchieta $^{187}$ (promovido e projetado pela Cooperativa Habitacional da Guanabara Ltda).

Em janeiro de 1968, ODC apresentava imagens do projeto Habitat 67 de Moshe Safdie para a Expo'67, em Cité du Havre, Montreal, Canadá, anunciado pelo governo canadense como uma construção industrializada experimental que representasse a busca por soluções para o problema habitacional dos grandes centros $\operatorname{urbanos}^{188}$. Contemporâneo da arquitetura metabolista japonesa e da ideia da habitação cápsula, o edifício era composto pelo agrupamento de módulos prismáticos de concreto de 90toneladas - que formavam apartamentos de 1 dormitório, com 54m2, até 4 dormitórios, com 154m2, e terraços ajardinados de até $100 \mathrm{~m} 2$, entremeados por ruas de pedestres e acessos verticais produzidos em usina implantada ao pé da obra e içados, já prontos e revestidos, por gruas até

183 Painéis leves de concreto permitem montar uma casa em 8 horas. O Dirigente Construtor. São Paulo, v. 1, n. 10, p. 47-50, ago. 1965. Técnicas e Materiais.

184 Casa mínima sai pronta da fábrica. O Dirigente Construtor. São Paulo, v. 1, n. 12, p. 47-53, out. 1965. Técnicas e Materiais.

185 Pré-fabricação pesada dá casa montada em cinco horas. O Dirigente Construtor. São Paulo, v. 3, n. 3, p. 22-26, jan. 1967. Técnicas e Materiais

186 Painel TIGRE hidráulico e elétrico (publicidade) em O Dirigente Construtor. São Paulo, v. 1, n. 12, p. 46 , out. 1965 .

187 Pré-fabricação total transforma conjunto Padre Anchieta em grande jogo de armar. O Dirigente Construtor. São Paulo, v. 2, n. 6, p. 12-19, abr. 1966. Projetos e Obras.

188 Habitat '67: engenho, diversifcação e custo elevado. O Dirigente Construtor. São Paulo, v. 4, n. 3, p. 16 20, jan. 1968. Projetos e Obras. 
a posição final. Até mesmo as cozinhas - produzidas pela empresa Frigidaire, que desenvolveu o sistema de manutenção e limpeza dos eletrodomésticos do módulo - e os banheiros, produzidos em cápsulas de resina com fibra de vidro, eram içados já inteiramente prontos.

Mas seria só em 1970 que os trabalhos de Frederico Schiel e Dante Martinelli ${ }^{189}$ — docentes de Resistência dos Materiais na Escola de Engenharia de São Carlos — sobre a argamassa armada ou os trabalhos do CEPLAN ${ }^{190}$ - cujos projetos foram elaborado por Oscar Niemeyer e João Filgueiras Lima, para a implantação da Universidade de Brasília (os Galpões para Serviços Gerais, o Alojamento de Professores e o Instituto Central de Ciências) iniciados ainda em 1962 (ano também da reforma curricular da FAUUSP), seriam apresentados em São Paulo.

\section{Os catálogos de edifícios patenteados}

As várias patentes para edifícios, desenvolvidas principalmente por empresas européias, eram veiculadas não só pelas revistas — desde o início dos anos 1960, como se mostrou anteriormente, com artigos das empresas brasileiras que importavam ou copiavam aqueles projetos - mas também por livros-catálogos ou enciclopédias que invadiram, no final da década de 1960 e início dos anos 1970, países que iniciaram tardiamente suas políticas para produção de habitação, como Espanha, conforme Fernandez Ordoñez ${ }^{191}$, e Brasil onde, conforme a $\mathrm{ODC}^{192}$, já em 1964 ao menos 10 processos patenteados aplicados na França já eram conhecidos.

Dessas enciclopédias algumas foram elaborada por Ernest Neufert ${ }^{193}$ — uma das referências desse período que perdura até hoje, usado acriticamente - arquiteto alemão expoente no estudo da padronização de dimensões, modulação e coordenação modular, cuja obra já tinha penetrado o Brasil desde os anos 1940.

Uma das características desses catálogos ${ }^{194}$, traduzidos para o espanhol, era a veiculação de processos patenteados na França na Inglaterra, na Alemanha, na Dinamarca e na Holanda,

189 Argamassa armada: amplas possibilidades de uso. O Dirigente Construtor. São Paulo, v. 6, n. 04, p. 3340, fev. 1970. Técnicas e materiais.

190 Acrópole. São Paulo, n. 369/370, jan-fev 1970. Edição especial sobre a Universidade de Brasília.

191 FERNÁNDEZ ORDÓÑEZ, 1974.

192 Nota sobre processos de pré-fabricação patenteados. O dirigente construtor. São Paulo, v. 1, n.1, p. 67, nov. 1964. Atualidades Mundiais.

193 NEUFERT,1945; 1965; 1970.

194 BARETS, 1965; COLLINS, 1963; 1965; 1967; DIAMANT, 1964; KONCZ, 1968; MOKK, 1964. 
países onde houve grande esforço na industrialização dos canteiros para a reconstrução no pós-guerra. Via de regra, as patentes eram elaboradas em grandes peças em concreto que, a depender do projeto, possuíam as mais diversas soluções para o encaixe entre si e diferentes graus de estaticidade. Quando painéis simplesmente encaixados, o conjunto constituía um sistema isostático, modelos adotados pelas patentes do norte da Europa, como a dinamarquesa Larsen-Nielsen. Quando, além de encaixados, os painéis eram solidarizados com capeamento de concreto, o conjunto constituía um sistema hiperestático, modelos adotados principalmente pelas patentes francesas, como as patentes Raymond-Camus, Tracoba, Estiot e Barets.

Além dos sistemas em painéis, também eram produzidos blocos técnicos em concreto que, empilhados, formariam um edifício. E havia também blocos técnicos para compor as instalações hidráulicas, banheiros e cozinhas prontos para serem içados e instalados dentro dos apartamentos, um dos desafios que também marcou o imaginário sobre a industrialização à época. As referências encontradas em Mário Oliveri $\left(1968^{195}\right)$ apresentam algumas fascinantes soluções em forma e materiais para essas cozinhas e banheiros.

Outra característica desses livros-catálogos eram os glossários de termos daquela produção. Não só tentavam diferenciar "pré-fabricado" de "industrializado", como apresentavam os diferentes tipos de produção: pré-fabricação leve, pré-fabricação pesada, sistema aberto, sistema fechado, industrialização total, industrialização parcial, pré-fabricação de fábrica, préfabricação de canteiro. Muitos desses termos não possuíam sentido para o Brasil, para os países periféricos ou mesmo para a Espanha, países onde a produção de habitação social ainda estava em estágio relativamente atrasado. Os países onde esses processos se desenvolveram viram sua aplicação e entendiam a diferença relativa a cada um. Por exemplo, por processos fechados de produção entende-se um sistema de componentes que possuem interfaces de montagem somente com o componentes da mesma patente, ao contrário de processos abertos, em que componentes diferentes, ou de diferentes empresas, possuem interface para serem usados também com produtos de outras empresas, ou substituir produtos similares.

Numa economia capitalista, os processos fechados começaram a se mostrar inviáveis ao longo dos anos 1960. A manutenção das edificações ou a necessidade de incorporar componentes produzidos por outras empresas já eram enfrentadas pelas discussões sobre coordenação modular, que ganharam impulso com o final da $2^{\circ}$ Guerra. Mas, mesmo com a coordenação modular, os processos fechados, ou as patentes, se tornaram em pouco tempo tecnologia 
obsoleta em face do desenvolvimento de componentes mais leves, que obviamente consumiam menos material, e com a incorporação de novos materiais.

Os catálogos justificavam que a divulgação das técnicas em evolução nos países vizinhos era fundamental para cristalizar tais processos. Em cada país, a discussão e a implantação das políticas habitacionais (inclusive de reconstrução de cidades no pós-guerra) se deu de maneira diferente mas, de maneira aproximada, essas patentes eram desenvolvidas por empresas que ganhavam concorrências públicas para produzir os conjuntos. Antes de ganhar a concorrência, no entanto, cada empresa investiu recursos e levou por volta de 5 a 10 anos para desenvolver e testar seus produtos habitacionais. Ou seja, depois de tempo e recursos investidos, as empresas tentavam desovar tecnologia obsoleta nos países que no final dos anos 1960 começavam a discutir política habitacional.

Ao citar as várias "modalidades" de produção estavam, na verdade justificando as patentes baseadas na pré-fabricação pesada como mais uma opção disponível entre outras.

Essa tentativa de definir os termos relacionados à arquitetura industrializada impregnou de tal modos os debates que até hoje nos vemos às voltas em tentar definir ou classificar os mesmos termos. Não só o trabalho de Paulo Bruna $\left(1976^{196}\right)$ usa o recurso do glossário para explicar o que é industrialização, como também o doutorado de Ana Paula Koury (2005) recorreu ao glossário 3 décadas depois.

\section{Cuba}

No início do ano de 1963, era grande a expectativa dos arquitetos brasileiros com o VII Congresso da UIA que seria realizado em Havana, Cuba, entre os dias 29 de setembro e 3 de outubro. O tom era percebido na fala de Eduardo Corona ${ }^{197}$, em Acrópole, sobre o tema escolhido para o encontro "A arquitetura nos países subdesenvolvidos", em que os arquitetos acreditavam que teriam a oportunidade de verificar experiências internacionais ao mesmo tempo em que debateriam e estudariam como enfrentar e solucionar as necessidades sociais, culturais e políticas para o desenvolvimento de seus respectivos países. Os subtemas propostos para o congresso eram: "Planejamento Regional", "Habitação", "Técnicas construtivas" e "Unidade de Vizinhança".

Vários países desenvolvidos, como Inglaterra, Suécia, Dinamarca, Japão, Áustria, Holanda,

196 BRUNA, 1976.

KOURY, 2005.

197 CORONA, Eduardo. VII Congresso da União Internacional de Arquitetos. Acrópole. São Paulo, n. 291, fev. 1963. Editorial. 
Bulgária e França levariam imagens e desenhos da sua produção de habitação mais recente, industrializadas com grandes painéis de concreto, para contribuir com o debate. Polônia, República Árabe Unida, República Democrática da Alemanha (antiga Alemanha Oriental), Romênia, Uruguai, Israel, Hungria, antiga Tchecoslováquia, e Chile também levaram imagens de sua produção. Os anais ${ }^{198}$ do congresso estão repletos de fotografias da melhor produção desses países.

E União Soviética e Cuba apresentariam ao mundo sua produção e davam mostra da eficiente máquina soviética de fazer casas, já que o Congresso era uma oportunidade de mostrar ao mundo os recentes resultados da revolução.

O Brasil também esteve presente no congresso, e foi representado pelos arquitetos do IAB de São Paulo, que assinaram o relatório brasileiro: Abelardo Gomes de Abreu, Alberto Botti, Alessandro Ventura, Arnaldo Furquim Paoliello, Bernardo Castelo Branco, Brenno Cyrino Nogueira, Joaquim Guedes, Jorge Wilheim, Juarez Brandão Lopes, Lauro Bastos Birkholz, Paulo de Mello Bastos, Paulo de Mello Zimbres, Raphael Gendler, Rubens Mattos Pereira e Sérgio Ferraz Pereira ${ }^{199}$. Outros arquitetos, como Ruy Ohtake, Paulo Mendes da Rocha, Pedro Paulo de Melo Saraiva ${ }^{200}$ e Vilanova Artigas $^{201}$ também estiveram no encontro.

O relatório brasileiro não levava a questão do subdesenvolvimento para ser debatida a partir dos subtemas propostos. O texto era iniciado com uma descrição do meio geográfico brasileiro (com descrição da população brasileira e suas características socio-culturais, além do meio físico e regiões climáticas) e apresentava um panorama histórico da ocupação do território dividido em 3 etapas: de 1500 a 1808, de 1808 a 1930 e de 1930 até então (1963), com cada etapa contendo a descrição da estrutura sócio-econômica, da arquitetura e das técnicas de construção utilizadas então. O relatório é revestido de certa arrogância pois, ao contrário de todos os outros países que se expuseram para um debate apresentando seus projetos urbanos e de habitação, com desenhos e imagens, o único exemplo do que se produzia no Brasil que os relatores levaram para o congresso foi Brasília e sua unidade de vizinhança, além das resoluções que os arquitetos tinham tomado no Seminário de Habitação e Reforma Urbana ocorrido em julho do mesmo ano.

Para a FAUUSP, no entanto, a viagem para Cuba deve ter tido um significado maior do que o

198 Congresso da União Internacional de Arquitetos, 7º 1963. A arquitetura nos países em via de desenvolvimento. Anais. Havana, Cuba, setembro de 1963. Volumes 1 e 2.

199 Acreditamos que Sérgio Ferraz Pereira é a grafia incorreta para Sérgio Ferro Pereira. Mas não pudemos verificar essa informação.

200 Conforme PEREIRA; GUERRA, 2011.

201 Conforme Dorfman, 2013. 
silêncio da comunidade da escola nesses 53 anos, desde 1963 até hoje, nos faz supor. No $6^{\circ}$ Congresso Internacional da UIA, de Londres, Buckminster Fuller sugeriu que o país a sediar o próximo encontro também sediasse um Encontro Internacional de Estudantes e Professores de Arquitetura, a primeira vez em que um evento desse tipo aconteceria.

César Dorfman, arquiteto gaúcho que participou do evento conta, em livro recém-lançado ${ }^{202}$, a experiência de aproximadamente 400 estudantes que viajaram para Cuba, para participar do encontro estudantil. No começo de 1963 alguns estudantes cubanos de arquitetura viajaram pela América Latina para promover o encontro. Ficou acertada que a viagem para Cuba iniciaria no início de setembro: a URSS enviou o navio Nadezhda Krupskaya pelo Oceano Pacífico para recolher os estudantes chilenos, argentinos, uruguaios e brasileiros. No Brasil, o navio recolheu estudantes nos portos de Santos e do Recife, seguindo pelo Atlântico até Havana. O encontro aconteceria entre 21 e 24 de setembro de 1963, seguido pelo VII Congresso da UIA.

Entre as aventuras juvenis que César Dorfman relata, as delegações estudantis de cada país, e também de cada região do Brasil, se reuniam no navio para elaborar as propostas que seriam apresentadas e debatidas no Encontro. Curiosamente, César Dorfman relata que os estudantes paulistas "tratavam de teses ligadas ao desenvolvimento da arquitetura, em particular da industrialização e dos sistemas de pré-fabricação" (2013, pág. 67). Paulo Bruna, conforme relato do próprio $^{203}$ e de Nestor Goulart Reis ${ }^{204}$, foi um dos estudantes a bordo do navio em direção a Havana.

Depois de uma viagem inesquecível - que Carlos Dorfman conta com nostalgia e que deve ter impactado para bem na vida de muitos estudantes — o retorno e o que se seguiu não foi tão feliz para vários daqueles estudantes. No retorno para a FAUUSP, pelo relato de Paulo Bruna, Artigas teria reunido seus estudantes quintanistas e recomendado fortemente para que desaparecessem; que o TGI poderia ser entregue discretamente em fevereiro de 1964. Afinal de contas, eles tinham ido para Cuba depois que o país assumiu o caráter socialista da revolução e estariam todos, provavelmente, fichados na polícia.

Paulo Bruna comenta que nunca teve qualquer problema por causa da viagem. Carlos Dorfman, envolvido com o PCB à época na ilegalidade, ao contrário, conta que, no final de abril de 1964, algumas semanas depois do Golpe Militar Brasileiro, foi preso, entre outros

202 Dorfman, 2013.

203 Entrevista concedida em 06 de março de 2015.

204 Entrevista concedida em 08 de abril de 2015. 
motivos, por causa da viagem e assim permaneceu por um mês com outros colegas.

Apesar de não haver indicação em local algum, nem nas revistas e menos ainda nos documentos da FAUUSP, parece óbvio porque a arquitetura Cubana da revolução e a aventura da viagem de navio para Havana ficaram esquecidas por tanto tempo. 


\section{BRANCO E PRETO}

DECORACOES E ARTESANATO
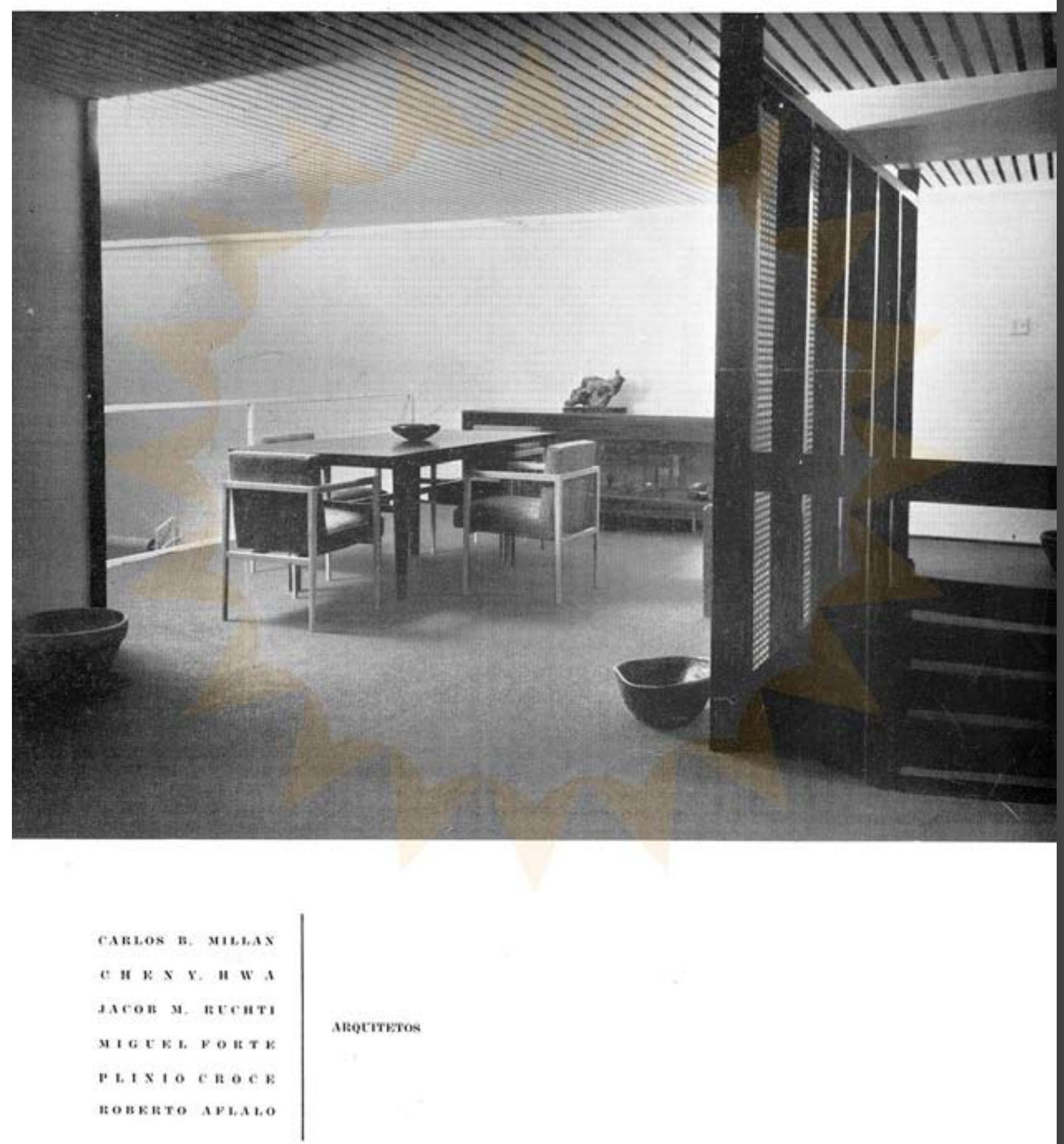

Publicidade da loja Preto e Branco, que comercializava móveis e objetos de artesanatos projetados porl Carlos Millan, Chen Y. Hwa, Jacob M. Ruchti, Miguel Forte, Plínio Croce e roberto Aflalo.

Acrópole. São Paulo, n. 177, p. XX, jan. 1953. 


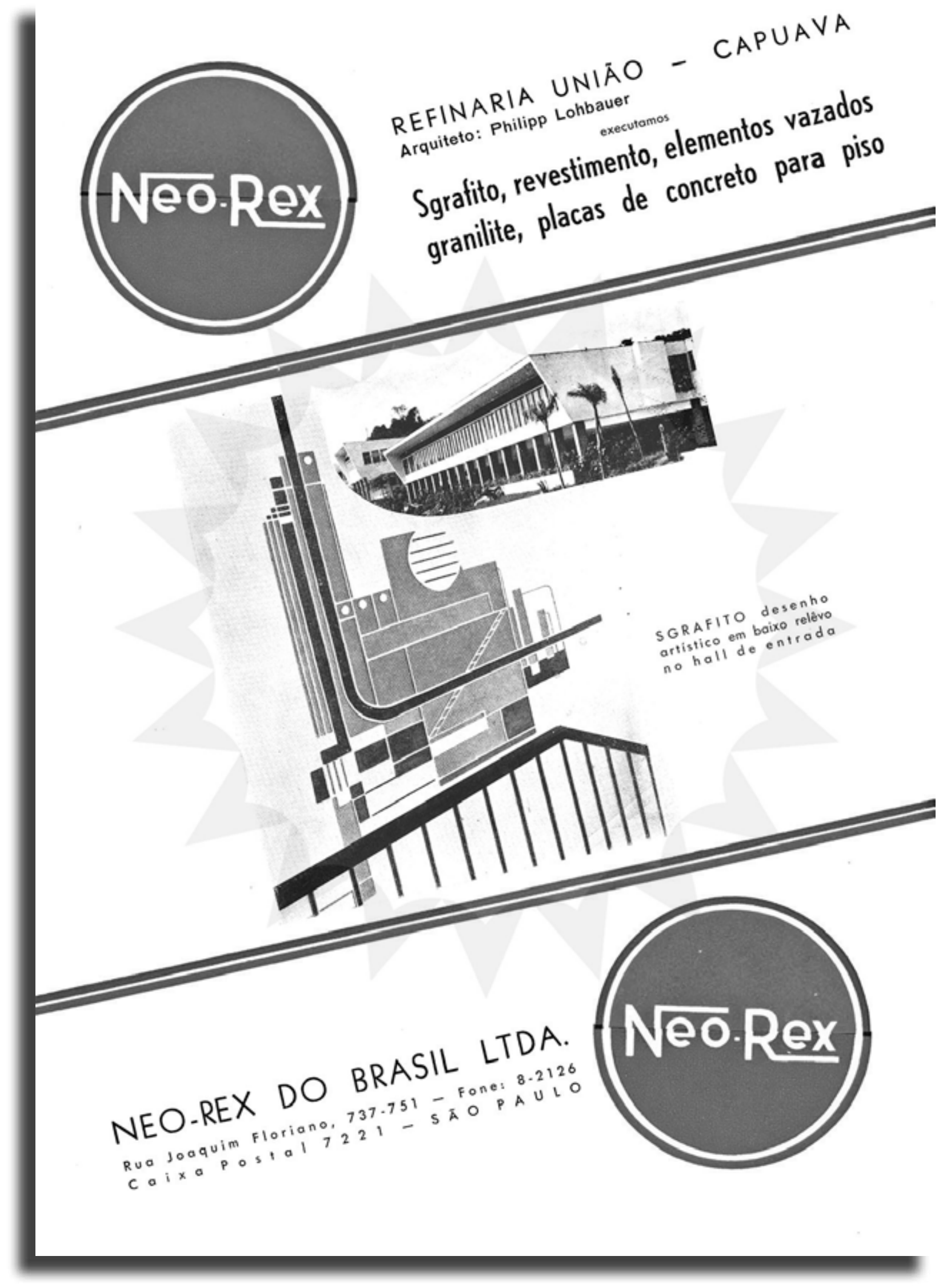



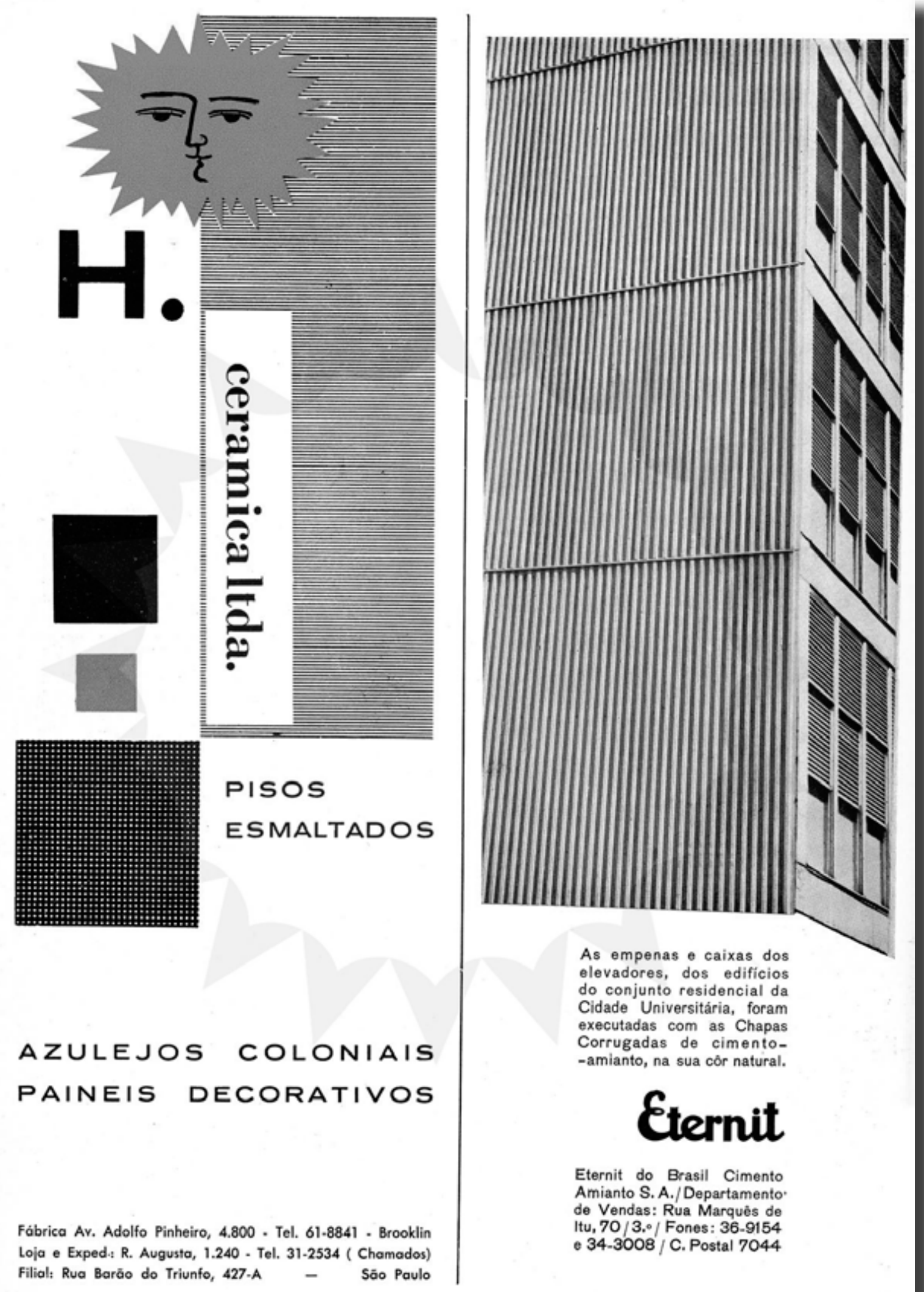

Eternit do Brasil Cimento Amianto S. A./ Departamento. de Vendas: Rua Marquês de Itu, 70/3.०/Fones: $36-9154$ e 34-3008 / C. Postal 7044

Publicidade dos painéis de cimento amianto da empresa ETERNIT, utilizados na construção do Conjunto Residencial da USP. Acrópole. São Paulo, n. 303, fev. 1964. 


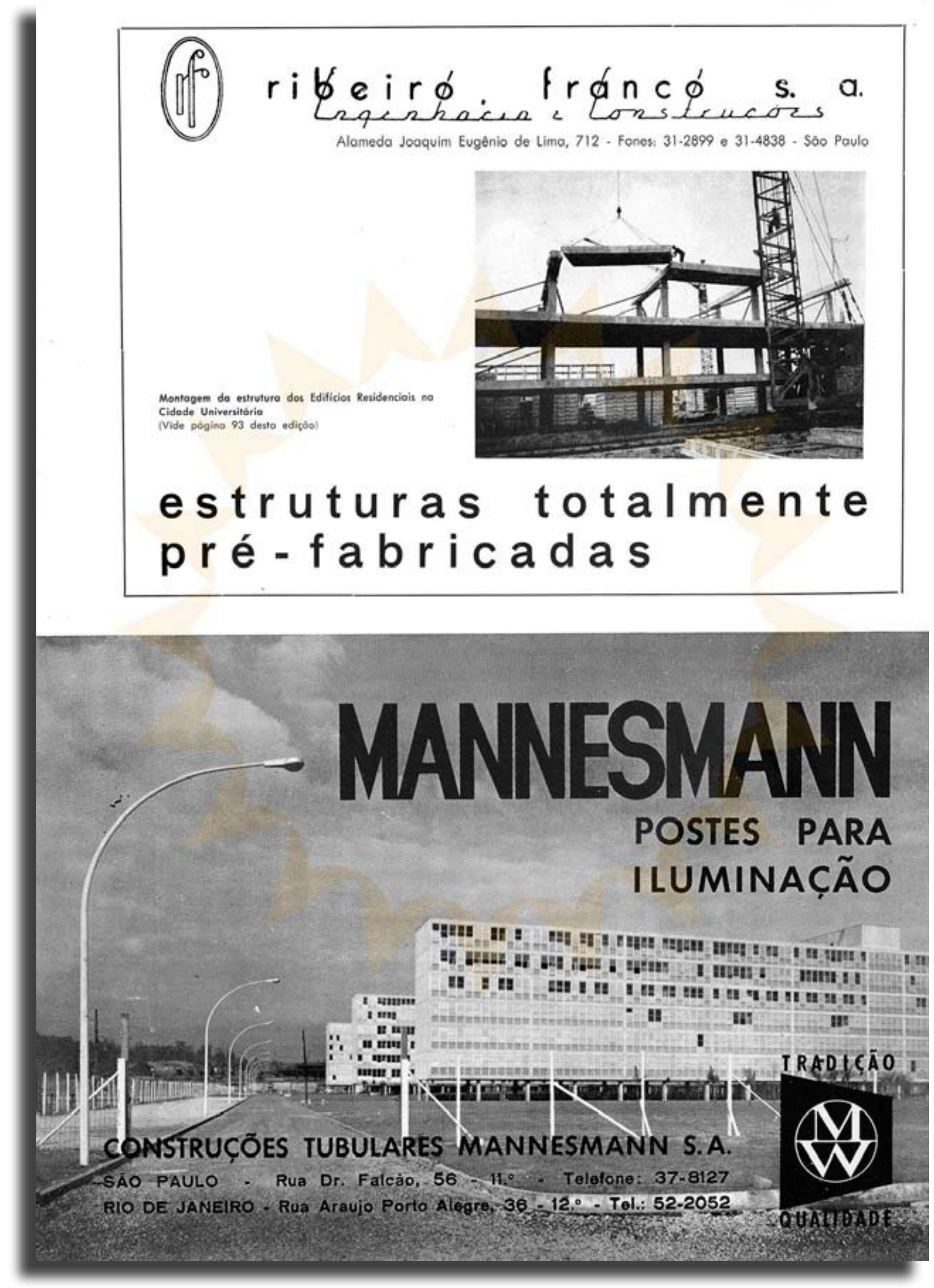

Publicidade da empresa Rlbeiro Franco — Engenharia e Construções, responsável pela construção de parte do Conjunto Residencial da USP. Acrópole. São Paulo, n. 303, fev. 1964 


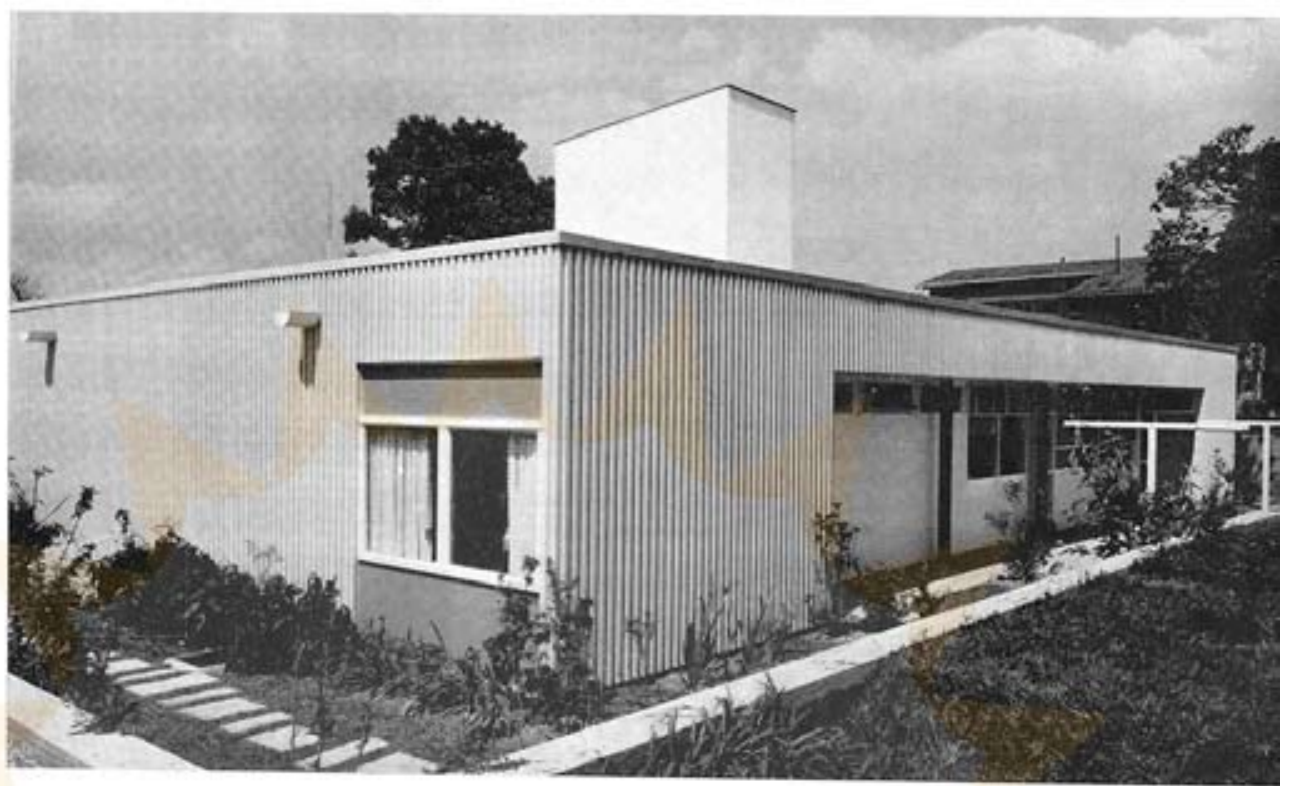

Esta residência foi proposta ao arquiteto pela própric fábriç, visando, em caráter experimontal, um protótipo de hobitoçôo industrializável. A precisőo requerido no produçáo dos montantes de modeira que servem à fixoçôo dos poinéis, dificultou no extremo a execuşōo da obra. Dela surgiram parém, por proposta do arquiteto, os atuais painéis "sanduiche" da Etornit, além da já fomosa ploco corrugada (como mostram os detalhes:

Artigo apresenta a casa ETERNIT, proposta à Carlos Millan pela empresa Eternit com caráter experimental. 0 trabalho conjunto resultou na produção dos painéis sanduiche de vedação por sugestão do arquiteto.

Residência Eternit. Acrópole. São Paulo, n. 332, p. 22-23, set. 1966. 


\section{VOLTERRANA ABÓBADAS}
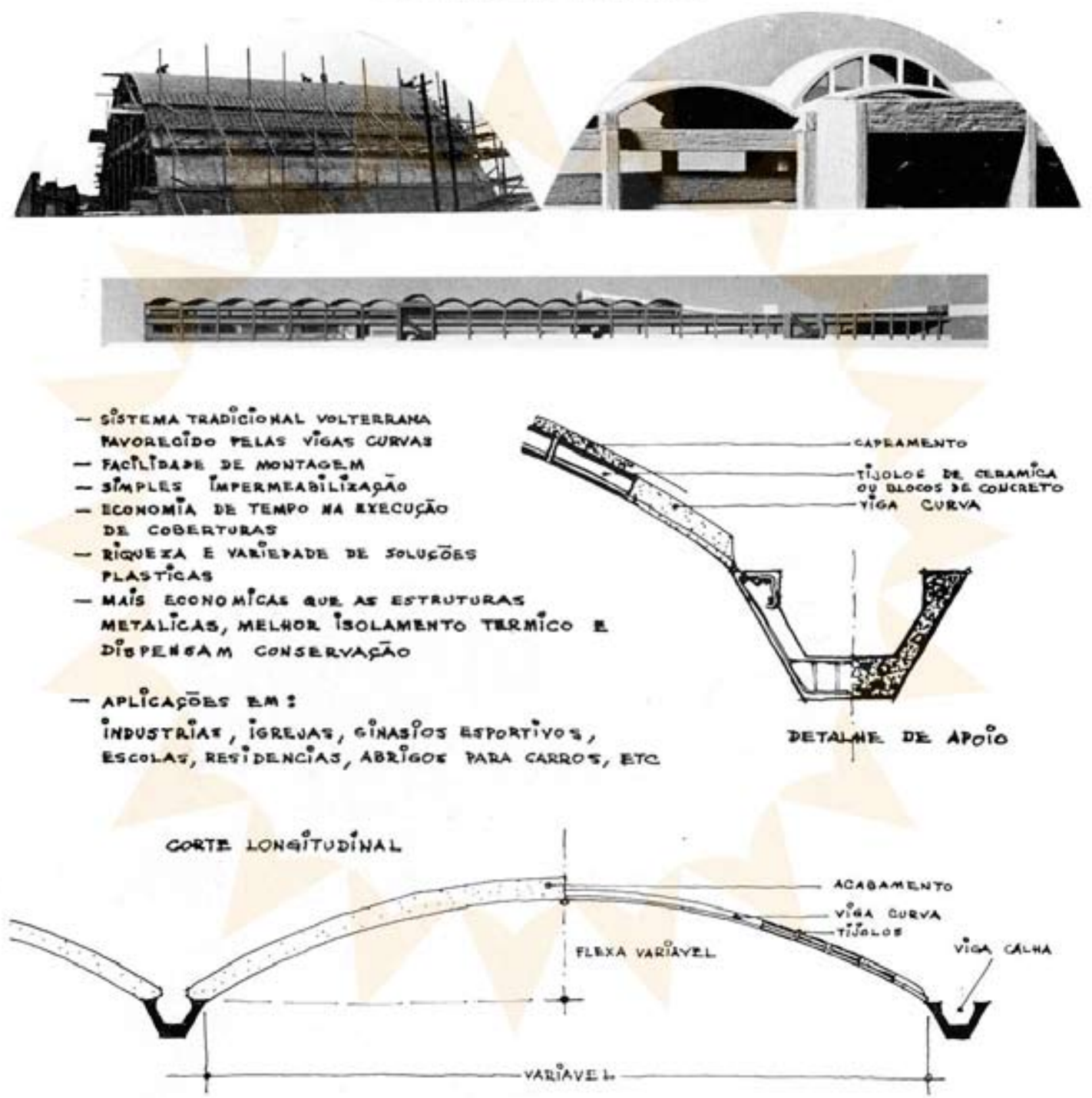

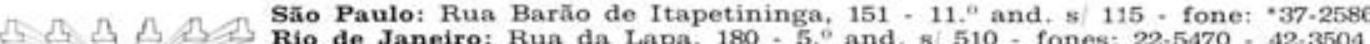
LAJES VOLTERRANA Belo Horizonte: Rua Silo Paulo, 893 - c 807 - telefone: 4-1326

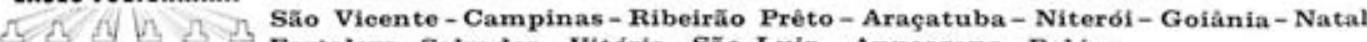
Fortaleza - Salvador - Vitória - São Luiz - Apuearana - Belém
}

Publicidade das lajes pré-fabricadas VOLTERRANA.

Acrópole. São Paulo, n. 348, mar. 1968. 

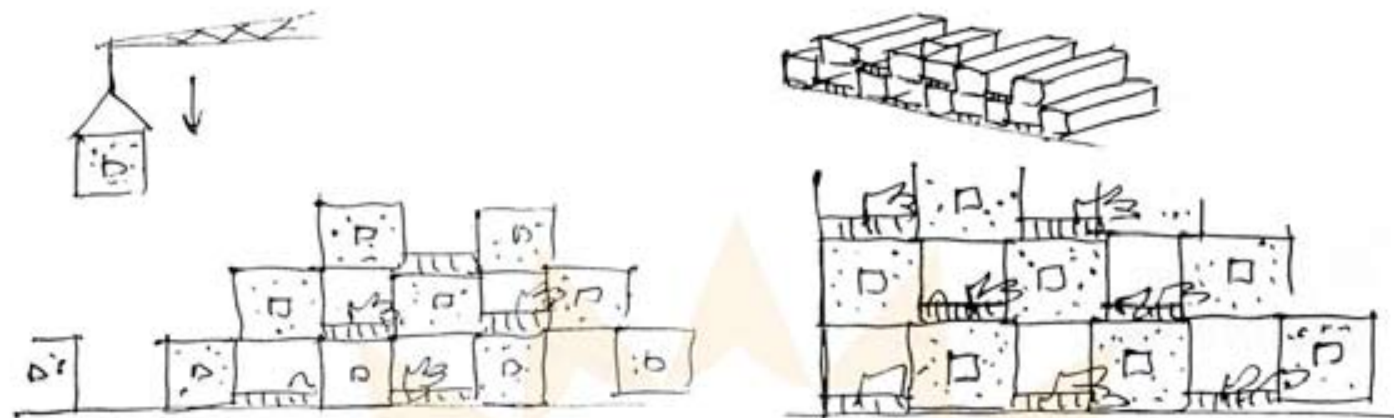

Com o objetivo de entrentar, em gronde escala, o problema habitocional de Brasilia, o orquiteto projetou em 1962 uma unidade pé́-fabricada.

Sua utilizaçâo permitio, desde a habitoçōo individual, distribuida no sentido horizontal, até a habitoçbo coletivo, com 2, 3 ou 4 pavimentos, através do superposiçảo alternado das unidades, de formo a criar, para cada cellula, uin jordim privativo.

Estas unidodes, igualmente pensados para resolver o problemo de aloiamento de estudantes, seriam localizados próximas ás Residências de Professôres, para o que se construiu um protótipo, com área própria de $45 \mathrm{~m}^{2}$ e pèso de 42 toneladas.

Doda a complexidade do transporte destas unidades, ficou a montagem do conjunto dependendo da construscóo do Usino de Pré-moldodos, previsto nos broximidades e ntio executado.

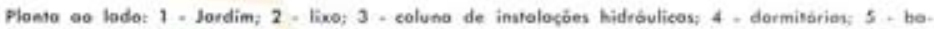

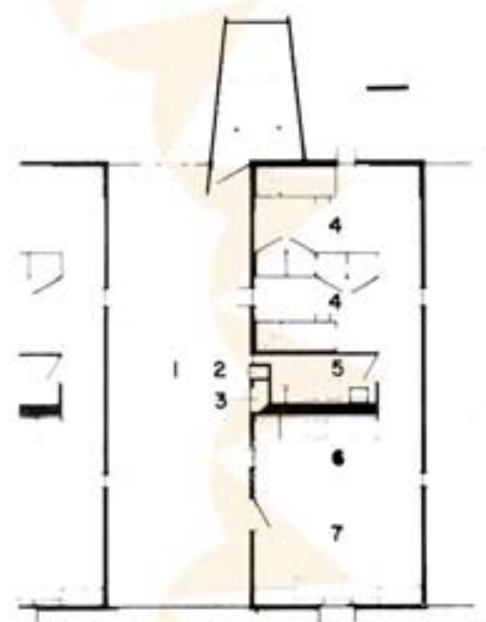

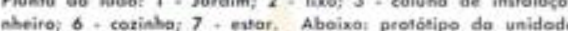

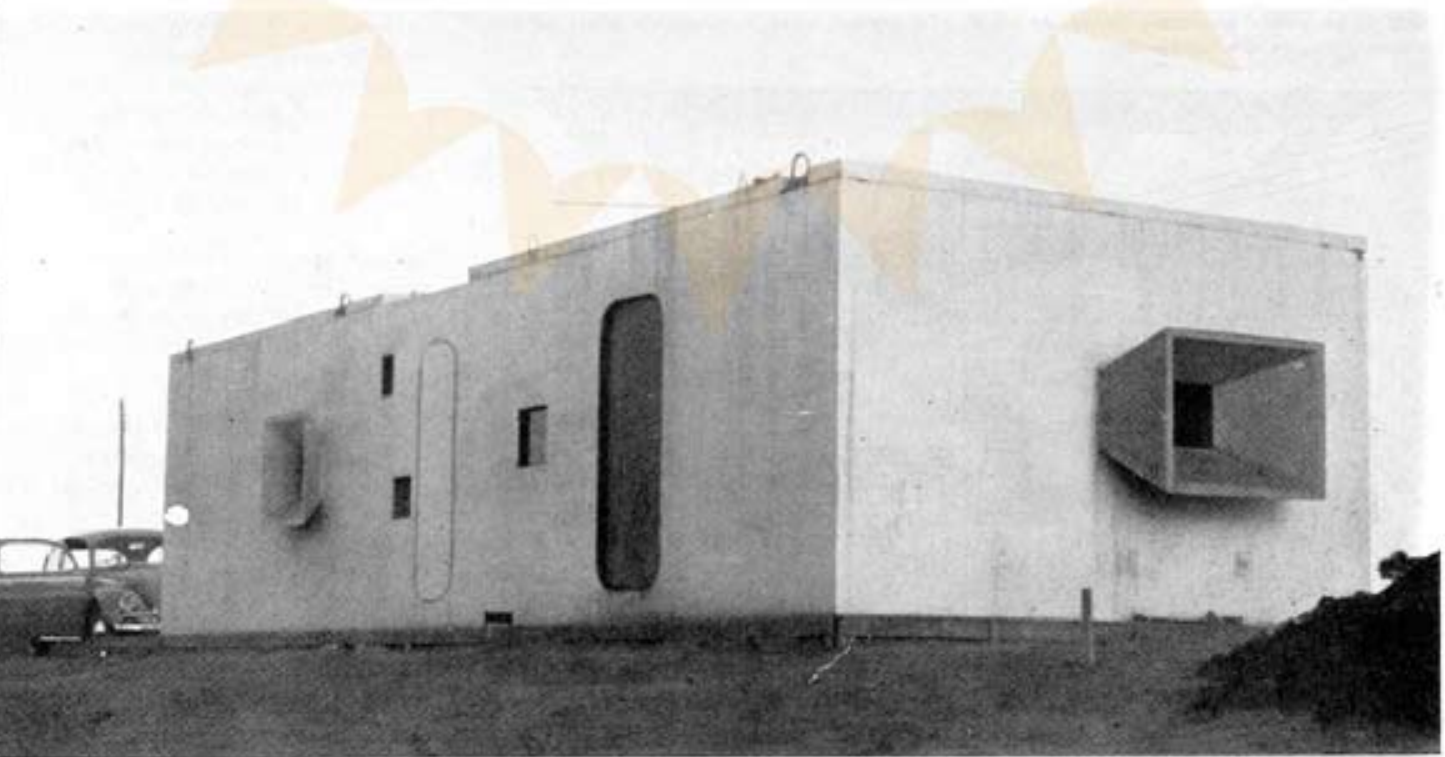

Artigo sobre proposta para habitação estudantil ou multifamiliar (mediante a sobreposição de unidades, conforme esquema da foto), desenvolvido por Oscar Niemeyer, para solucionar o problema habitacional em Brasília. Somente o protótipo foi executado.

NIEMEYER, Oscar. Habitações coletivas. Acrópole. São Paulo, n. 369, p. 29, jan. 1970. 


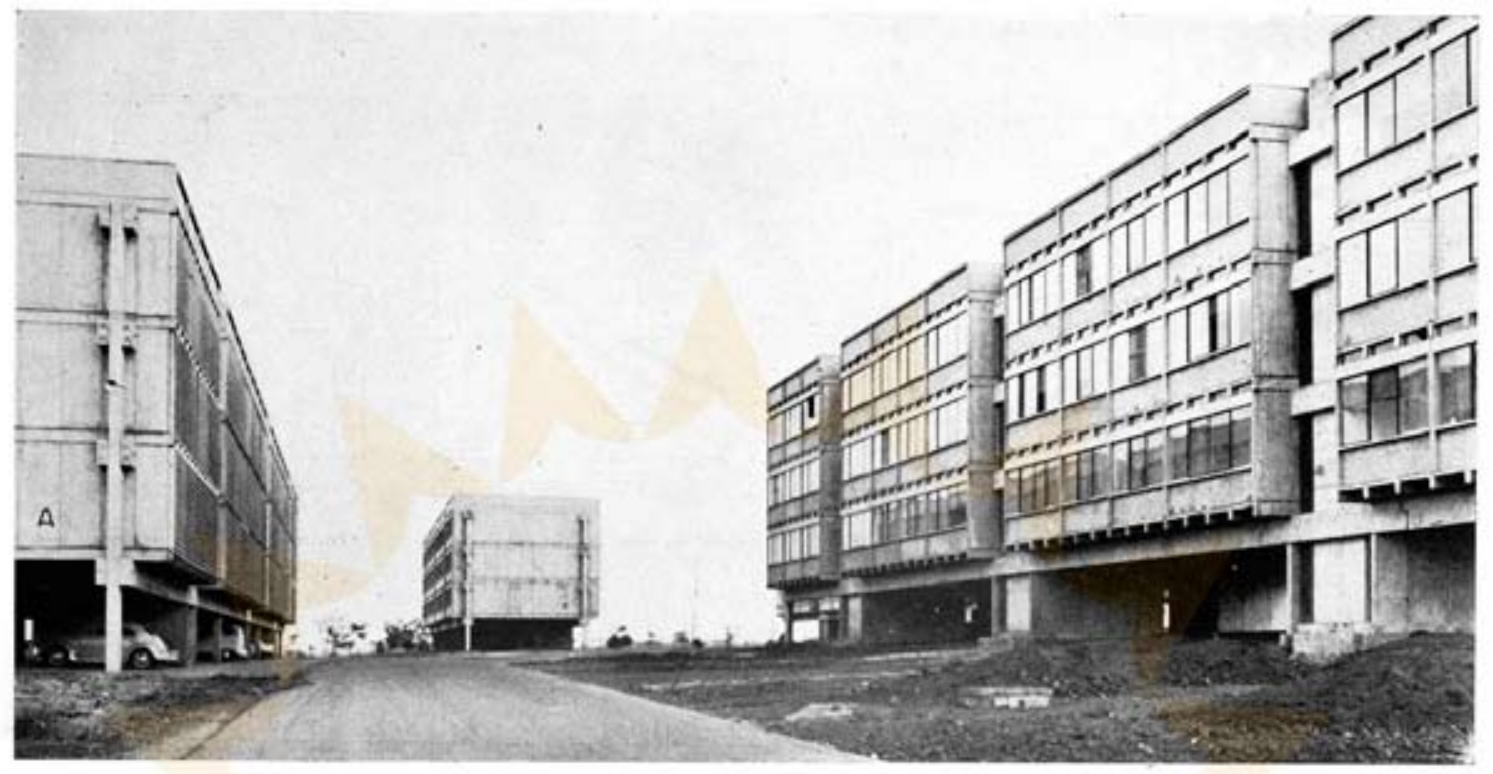

projeto: Joáo Filgueiras Lima, arquiteto construçào: Christiani Nielsen S.A.

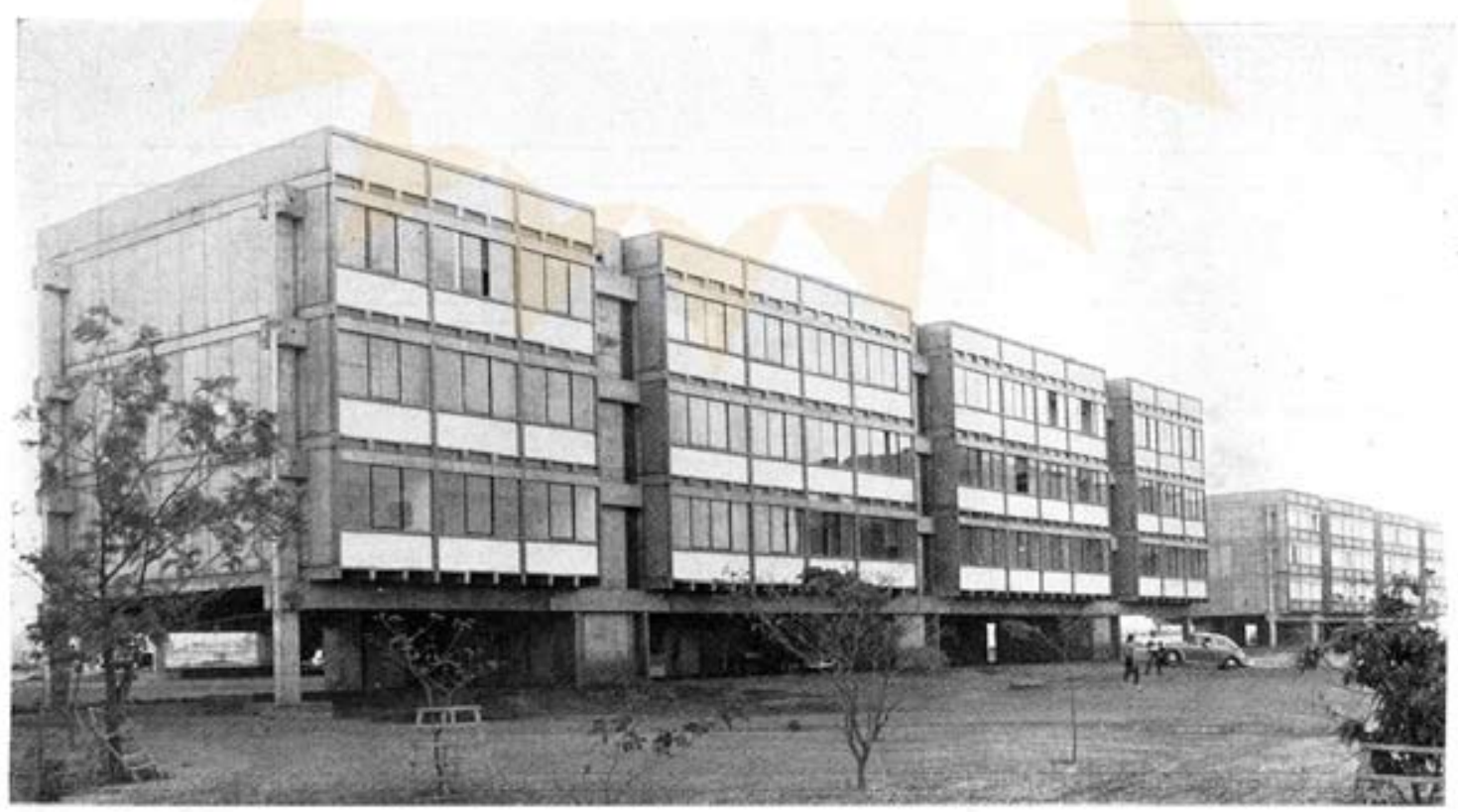

Artigo sobre os Alojamentos de Professores, da Universidade de Brasília, construídos em elementos pré-fabricados de concreto.

LIMA, João Filgueiras. Alojamento de professores. Acrópole. São Paulo, n. 369, p. 32-34, jan. 1970. 


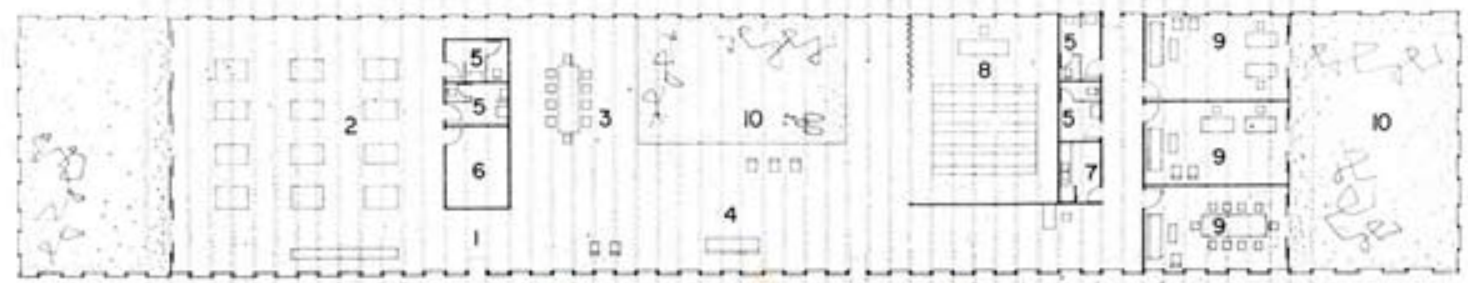

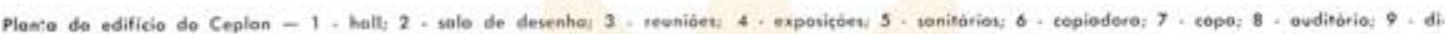
rę̧áo; 10 - jardim
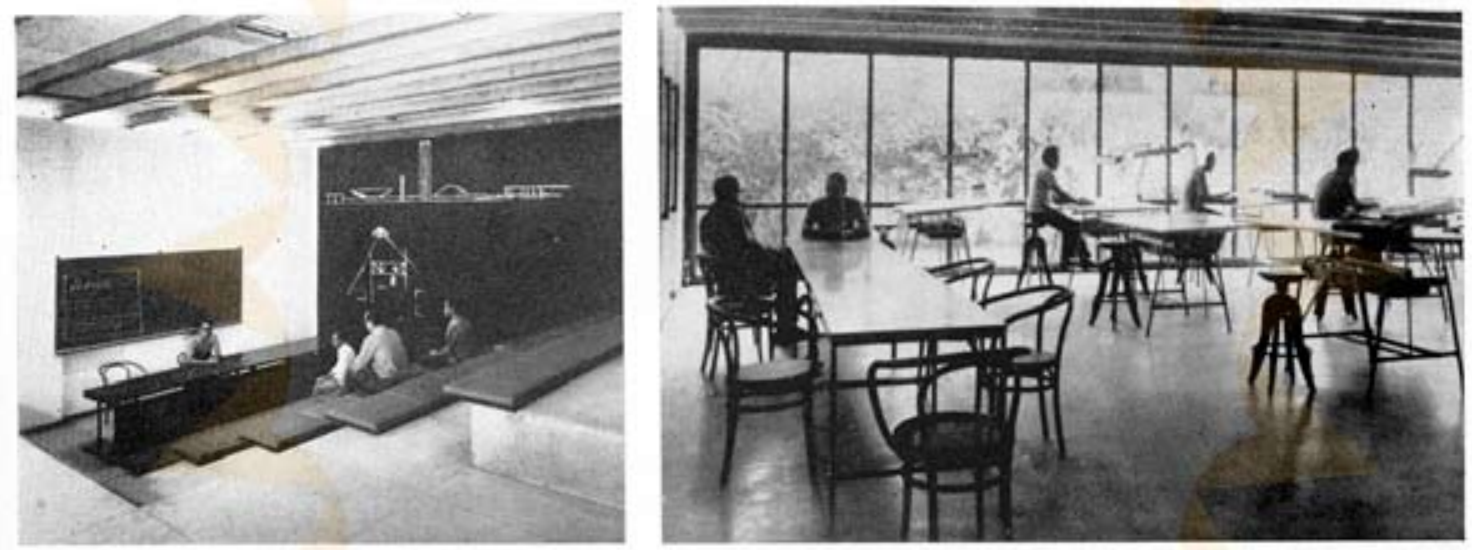

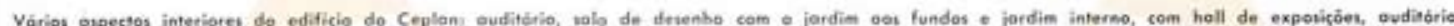
a salos do Diresóo

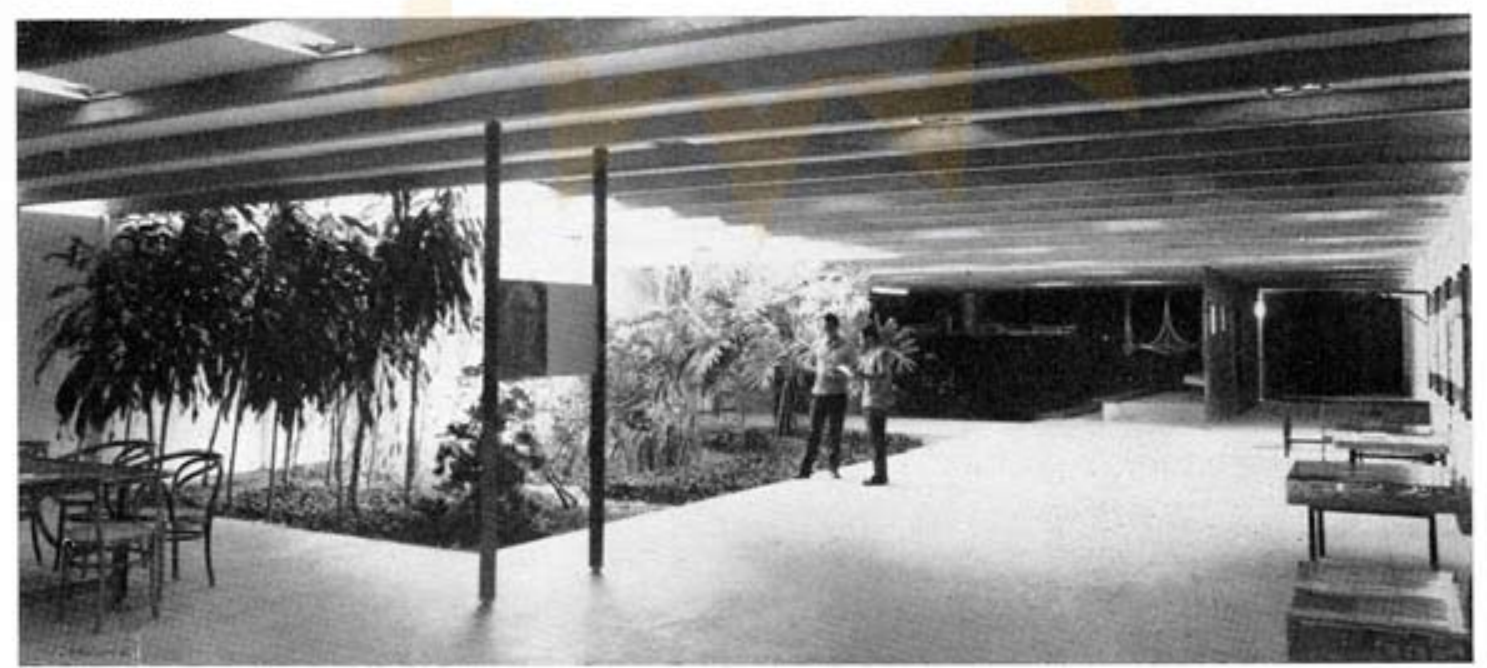

Artigo sobre edifícios projetados por Oscar Niemeyer e desenvolvidos por João Filgueiras Lima para as instalações da Universidade de Brasília.

LIMA, João Filgueiras. Galpão para serviços gerais. Acrópole. São Paulo, n. 369, p. 40-41, jan. 1970. 

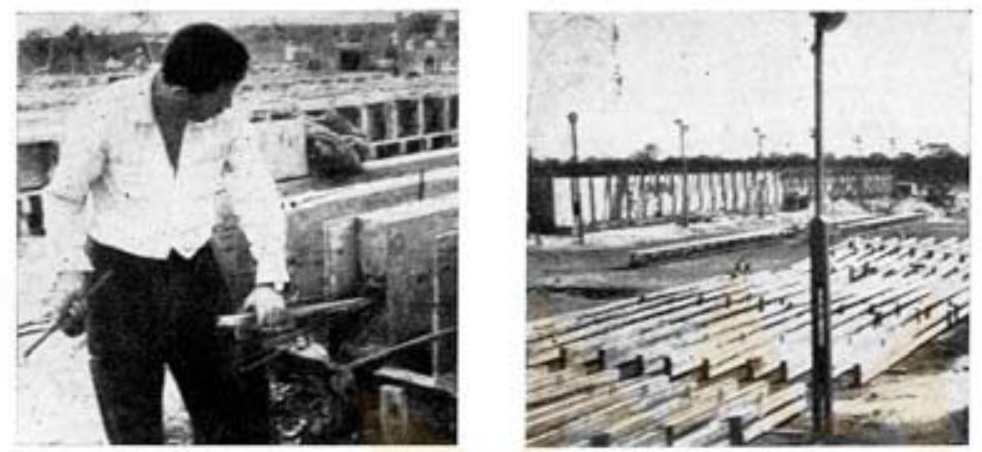

1,2 Protensáo das vigas de cobertura

Vigamento da soberture jo monted

4 Visto inserne de um des bleces

5,6 fitorogem e tromsporte dos elementes pert. moldodos dos porectos

Detalhe da amorrosáo dos éementos pré-

moldodos dos pored

- Cortines des edificios, jú montador
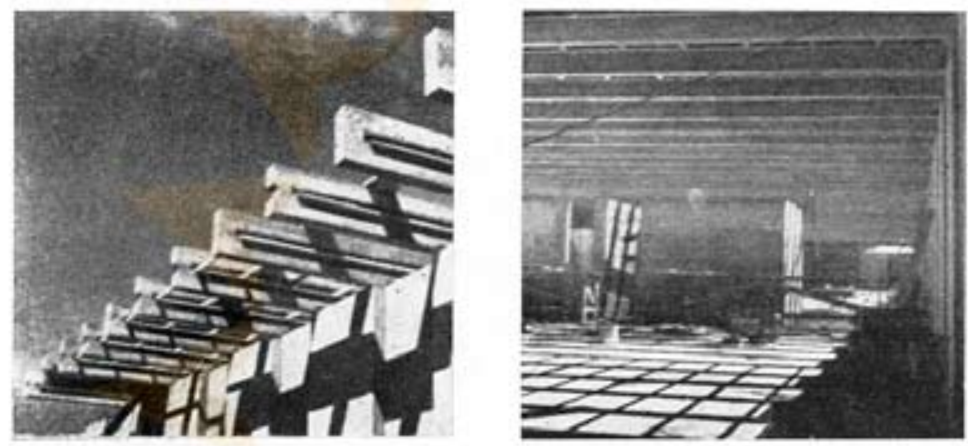

Crequits de prindipio canasivivo
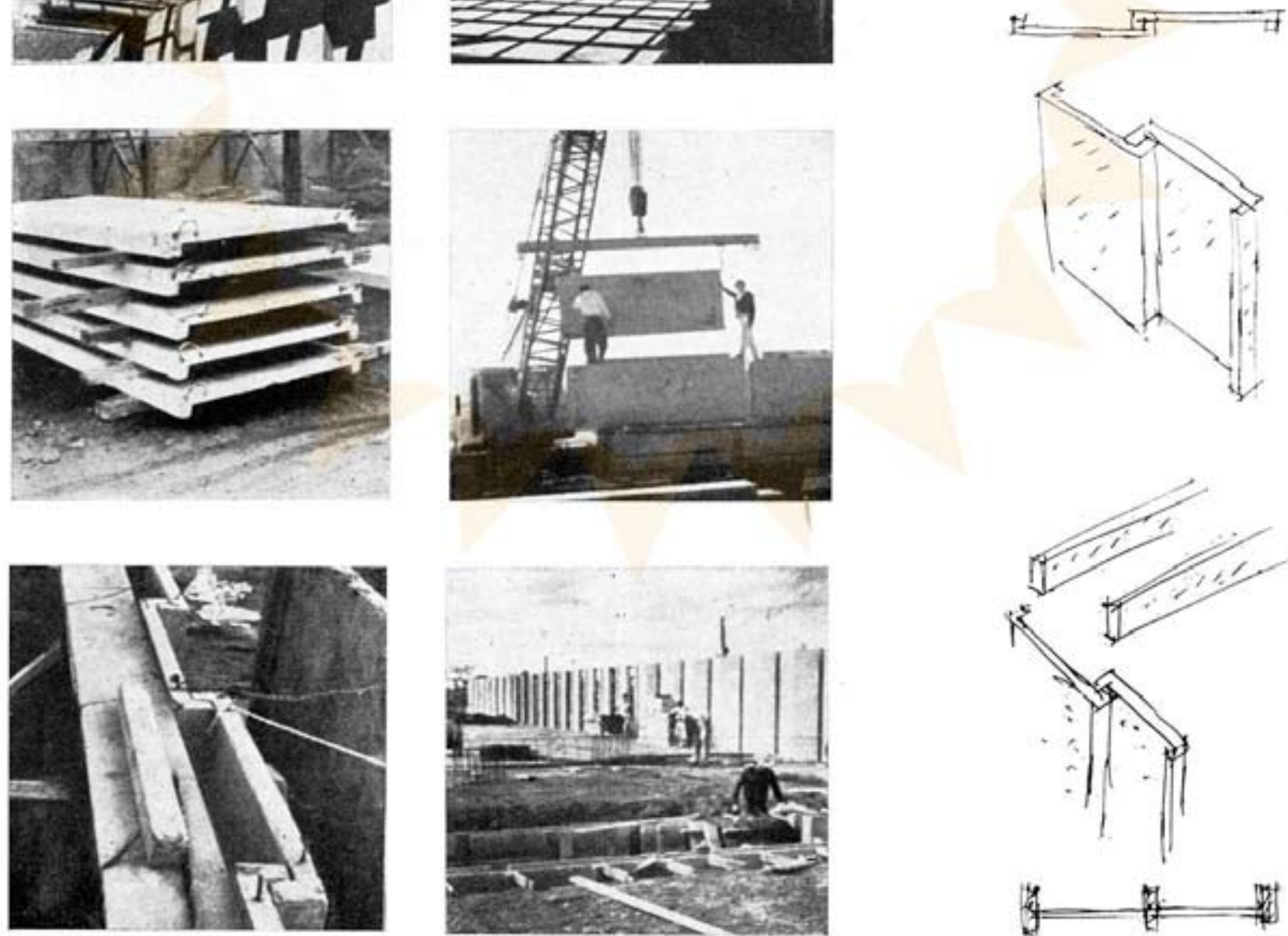

Artigo sobre edifícios projetados por Oscar Niemeyer e desenvolvidos por João Filgueiras Lima para as instalações da Universidade de Brasília.

LIMA, João Filgueiras. Galpão para serviços gerais. Acrópole. São Paulo, n. 369, p. 40-41, jan. 1970. 


\section{Lajes Volterrana}

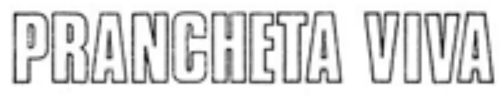

Fabricodas pela tojes Volterrana S.A. Ind. - Com

Rua Bardo do Itopatiningo, 151, 11, Säo Paulo
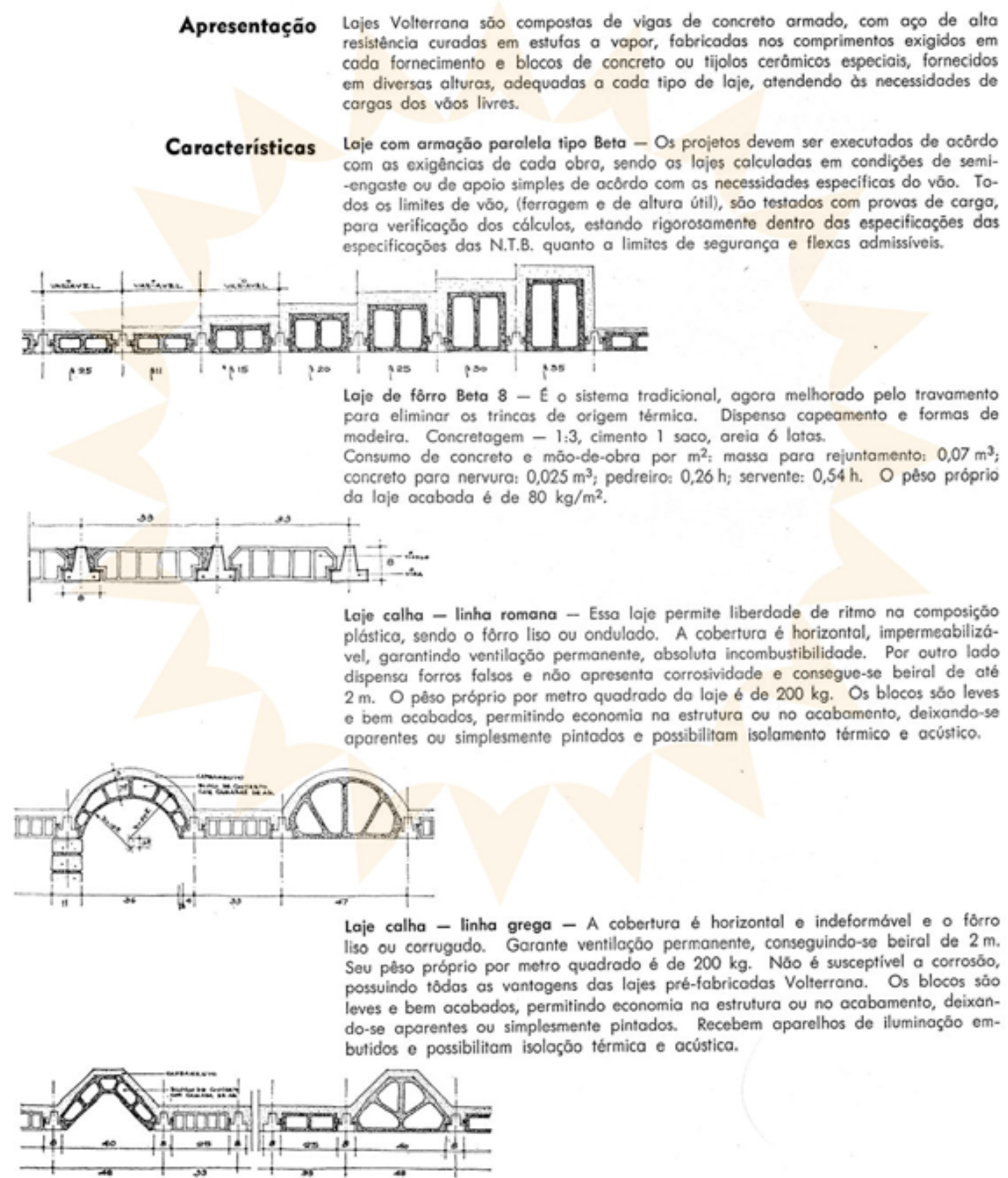


\section{PRÉ-MOLDADOS DE CONCRETO}

\section{compensam para estruturas em série}



Os lances da escada tambèm săo pré-moldados e parafusados na estrutura do prédio 46
Várias iniciaticas em curso de. monstram que a pré-fabricaçẫo, tanto de elementos estruturais, quanto de painétis de vedaçâo, começa a ganhar adeptos. A firma Ribeiro Franco S.A. de São Paulo, SP, desenvolveu um sistema próprio de pré-moldados de concreto $e$ efetuou uma experiéncia em edificios da Cidade Unicersitária. Fi. caram patentes as vantagens gerais oferecidas pelo sistema da pré-fabrica. cáo em série, apesar de terem ocorrido alguns percalças.

Com um guindaste e sete homens é possivel montar, em 28 horas, a estrutura de todo um pavimento de edificio de dimensões regulares em peças pré-fabricadas.

Esse foi o resultado akcançado pela Ribeiro Franco S.A. - Engenharia e Construçóes, de Sĩo Paulo, sp. na construçio das estruturas de seis dos doze prédios que compóem o con. unto residencial da Cidade Universitária de São Paulo, onde foram utilizadas pecas de concreto pré-moldadas.

A iniciativa foi de caráter experimental, tendo em vista o possivel emprègo posterior. em escala mais ampla, de pesas estruturais de concreto pré-moldado

Por se tratar de uma primeira experiência, surgiu, segundo a própria firma construtora, uma série de con. tratempos e imprevistos, que se refletiram nos resultacios econômicos do empreendimento, embora não chegassem a invalidar as conclusões obtidas.

Ficou demonstrado, por outro lado, que o sistema apresenta uma série de vantagens em relaçẩ a processo tradicional e que, desenvolvido em larga escala, resultará em economia e rapidez nas construçōes.

Moldagem, cura, transporte e montagem sẫo as operaçōes fundamentais enfrentadas peios construtores que, embora nåo tenham criado un

Artigo sobre a construção do Conjunto Residencial da Cidade Universitária, projetado pelo Arquiteto Eduardo Kneese, em que se aplicou o sistema de elementos pré-moldados de concreto desenvolvidos pela construtora Ribeiro Franco S.A. - Engenharia e Construções em seis dos doze edifícios totais.

Pré-moldados de concreto compensam para estruturas em série. O dirigente construtor. São Paulo, v. 1, n.1, p. 46-52, nov. 1964. Técnicas e Materiais. 


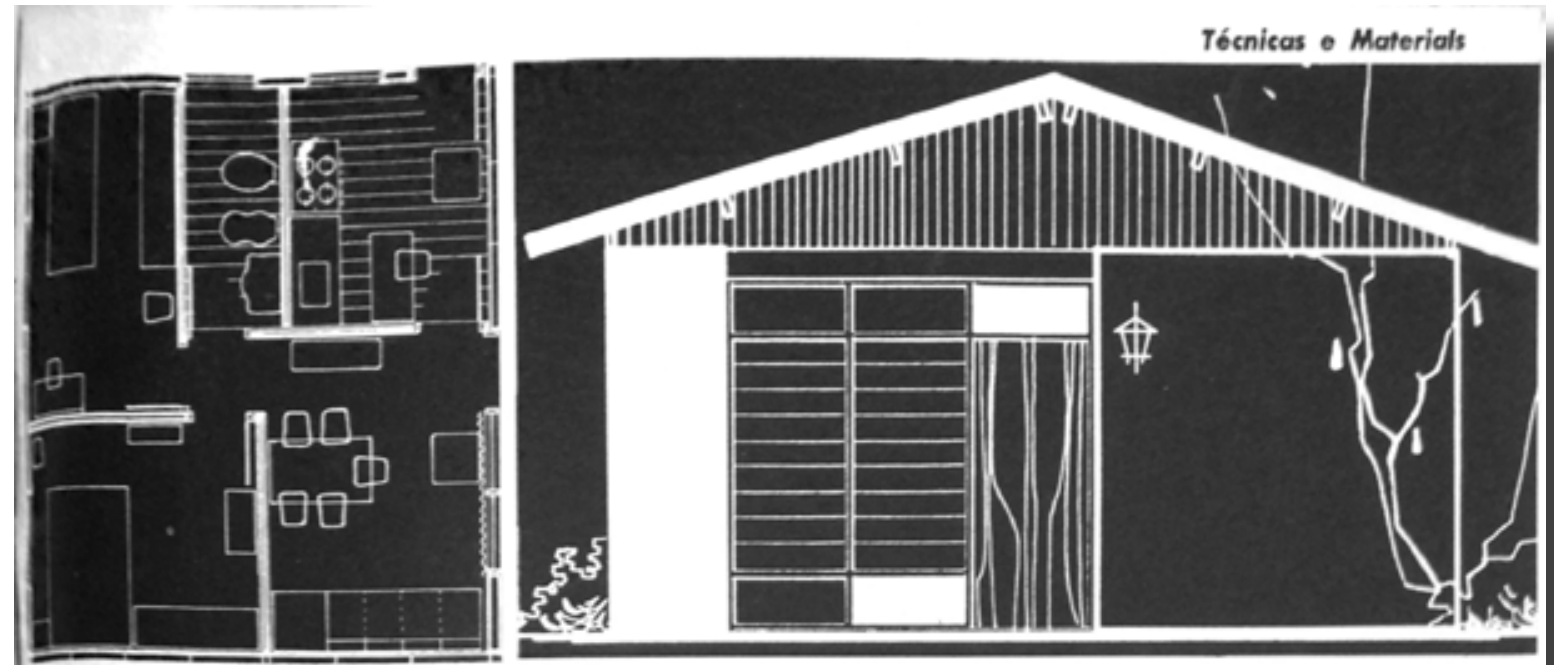

A casa-modtlo, que ocupa área de 44,50 metros quadrados, com p6 direito de 2,70 metros, recebeu acabamento especial

painéis leves de concreto

permitem montar

\section{UMA CASA EM 8 HORAS}

Yeion rendimento do material $e$ mäode-obrs foram alguns dos objetivos viwolos no planejamento de casas consthidar de painéts de concreto pré. moldodos e justopostos, montados com arilio de equipomento mecdnico em poucts honas. A estrufura monolitice der cavar oferece novas possibilidades so ietor de casas préfabricadas. $O$ ziterna teria por base uma rêde de sinarplibo para moldagem dos paistit e eficiente servico de distribuiçlo.

O ponto de partida foi a adequaçî́o do material ao método de cons. trogia. Como resultado dessa premis. s. em equipamento mecânico, espeduloente projetado, justapöe com faelldade painéis nervurados de concre. hy, dois a dois, num sistema idealizado por una firma paulista com o objetivo de reduzir tempo e custos de construfilo de grandes conjuntos residenciais.

Pequenas modificaçues na linha de produção permitem obter painéis qe servem para paredes estruturais, civićrias, forros e lajes. A racionali. aclo alcancada enseja, segundo os

O DECETE CONSTRUTOR, AGOSTO DE 1965 fabricantes, que uma casa com área de $37 \mathrm{~m}^{2}$ possa ser montada em apenas 8 horas, se a mão-de-obra utilizada estiver convenientemente treinads.

\section{Vanfagens alcançadas}

O sistema foi patenteado pela firma Usitec - Usina Técnica de Concretagem Ltda., de São Paulo, SP, que já montou e apresentou a sua primeira residência. Bàsicamente, o processo em. prega painéis nervurados de concreto. dotados de armadura interna, que ao se justaporem deixam vazios no miolo da peça montada.

Esses painéis são fixados nos baldrames, as juntas entre cada par de elementos sấo preenchidas com arga. massa e o fôrro, também de placas, com as nervuras voltadas para cima, completa o travamento. Os elementos săo dimensionados para atender a um determinado número de funçōes na estru. tura, principalmente nas casas tipo po. pular, embora possam ser aproveitados em estrutura de maior porte. O resultado final obtido é um todo monolítico.

Os fabricantes apontam as seguintes vantagens do sistema:
- Adapta-se a qualquer tipo de projeto arquitetônico;

- Abrevia o tempo de construçio:

- Possibilita excepcional rendi. mento da mấ-de-obra;

- Reduz o desperdicio de material a taxa insignificante;

- Resiste bem a intempéries;

- E durável;

- Pesa pouco;

- Dispensa cortes, rasgos e tu. bos, tanto para instalaçōes elétricas co. mo hidráulicas;

- Resulta em maior espaço útil, devido a pouca espessura das paredes.

\section{Usinas-pilôto}

O projeto do sistema adotado pela Usitec fol elaborado pelo arq. José Alberto Marialva Marques e tem por base a utilizaçäo de usinas-piloto, que fabricam os elementos estruturais em quantidade suficiente para alimentar as obras em ritmo acelerado. Prevê-se, inclusive, que essas unidades estejam capacitadas a operar económicamente num raio de até $100 \mathrm{~km}$.

A primeira usina montada pela emprêsa na Capital Paulista possui

Artigo sobre o processo construtivo para habitações, baseado em paineis leves pré-fabricadas em concreto desenvolvido pela USITEC — Usina Técnica de Concretagem Ltda. Painéis leves de concreto permitem montar uma casa em 8 horas. O Dirigente Construtor. São Paulo, v. 1, n. 10, p. 47-50, ago. 1965. Técnicas e Materiais. 

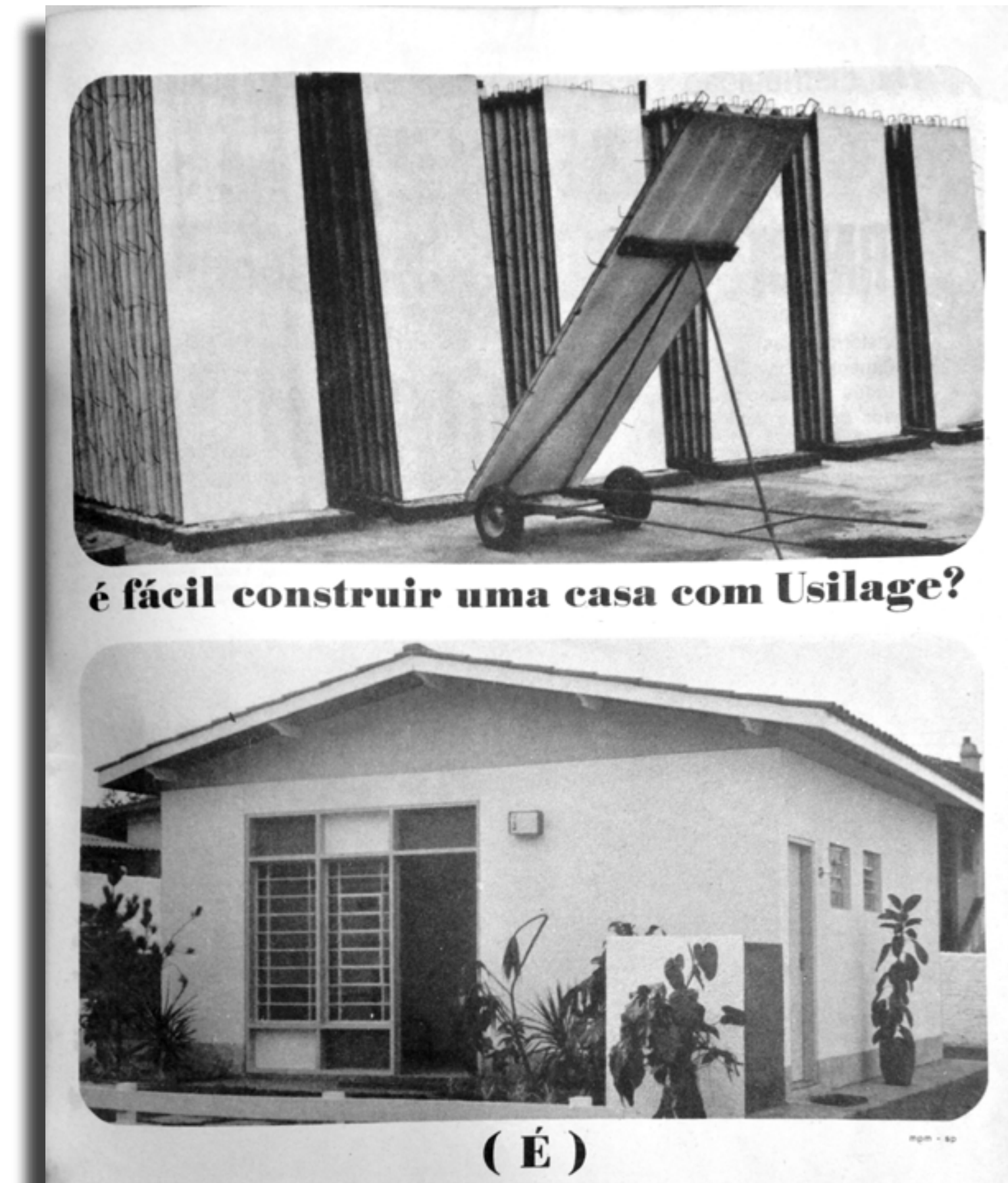

O Sistema de Construção Usilage é um processo industrial de modulação de painéis e placas (nervurados), executados em concreto armado vibrado e submetido a tratamento térmico.

Pode ser empregado em qualquer projeto arquitetônico, economizando argamassa de assentamento e revestimento (já vêm recobertos com massa fina), tempo de trabalho e mão-de-obra (preço

de custo mais baixo). Viu como é fácil construir uma casa com Usilage?

painéis e placas: 노피르르 produtos da

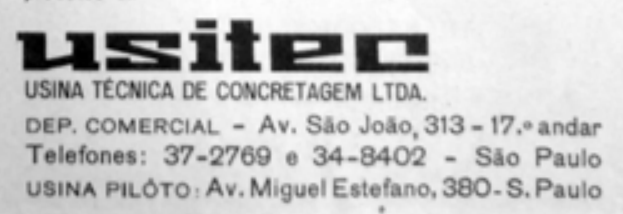

Publicidade do sistema Usilage, de painéis leves pré-fabricados em concreto da USITEC — Usina Técnica de Concretagem Ltda. O Dirigente Construtor. São Paulo, v. 1, n. 11, p. 01, set. 1965. 


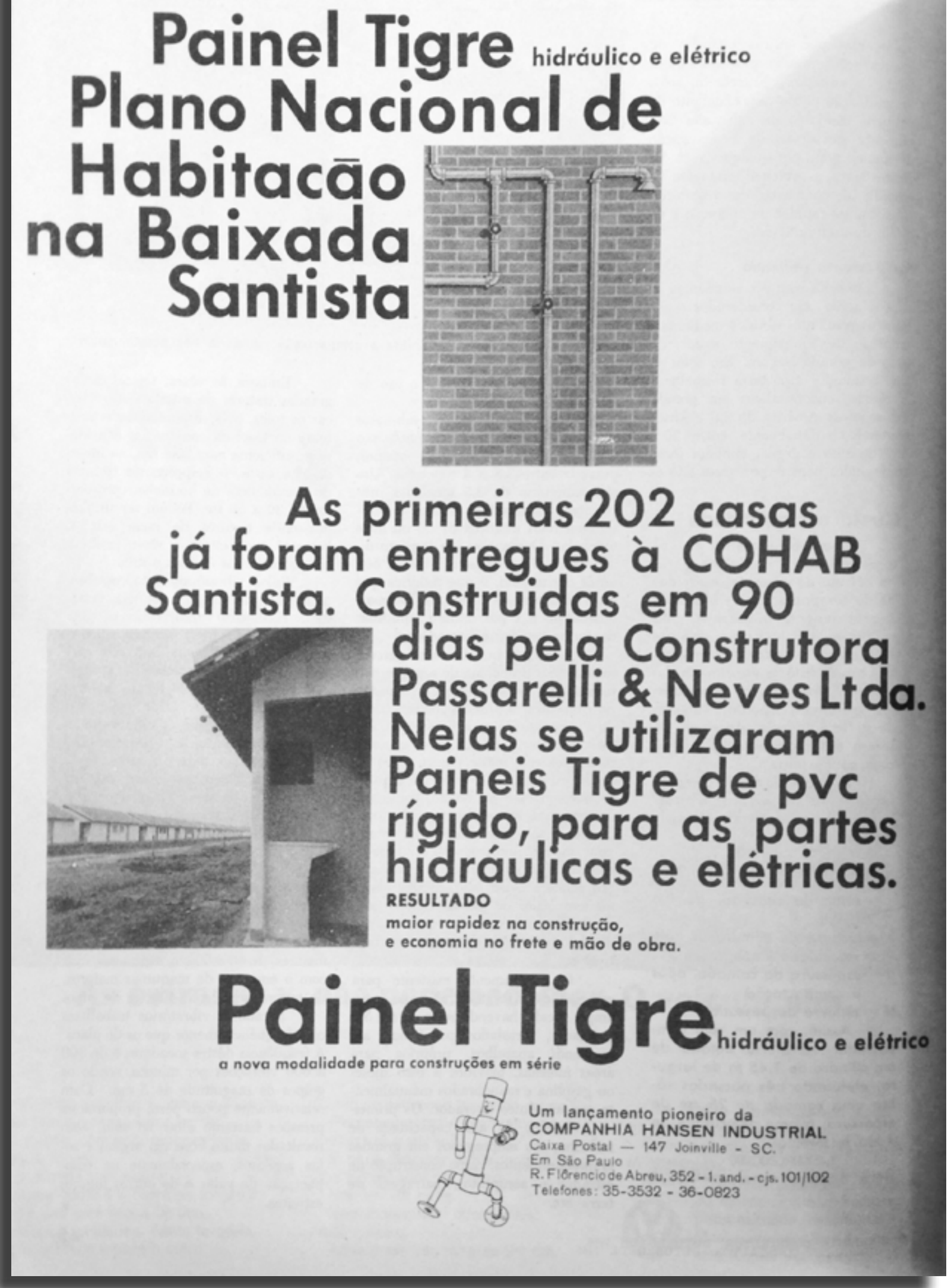

Publicidade dos painéis prontos da Tigre para instalações elétricas e hidráulicas.

O Dirigente Construtor. São Paulo, v. 1, n. 12, p. 46, out. 1965. 
NOVA ERA

PARA A

CONSTRUÇAO CIVIL

BRASILEIRA

CONSTRUÇÃo INDUSTRIALIZADA NACIONAL S. A.

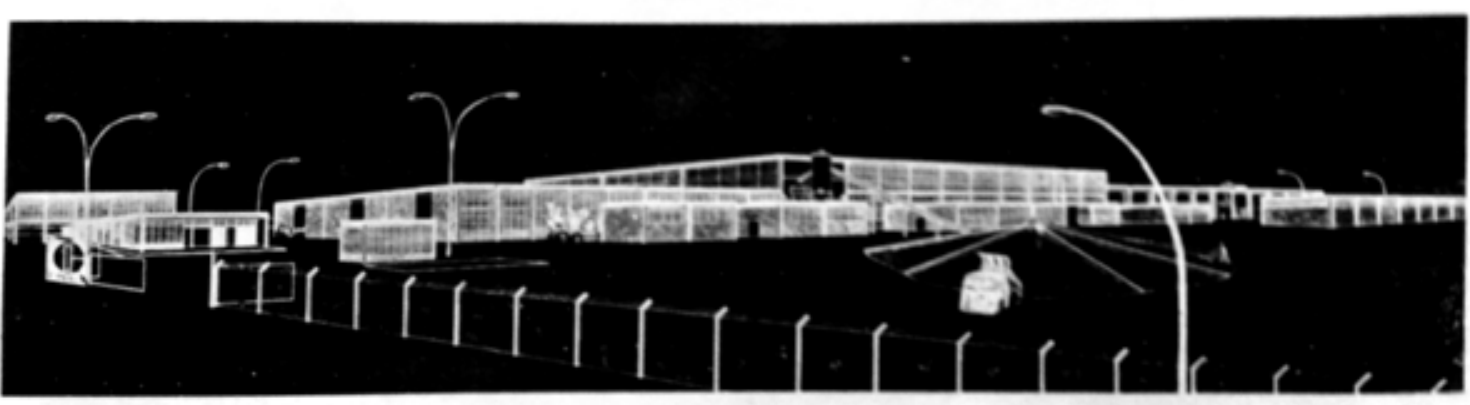

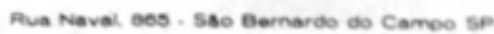

a primeira grande usina de pré-fabricaçāo total no Brasil, com início de operaçăo previsto para dezembro de 1965 


\section{para curisucugues}

rápidas, duráveis e econômicas

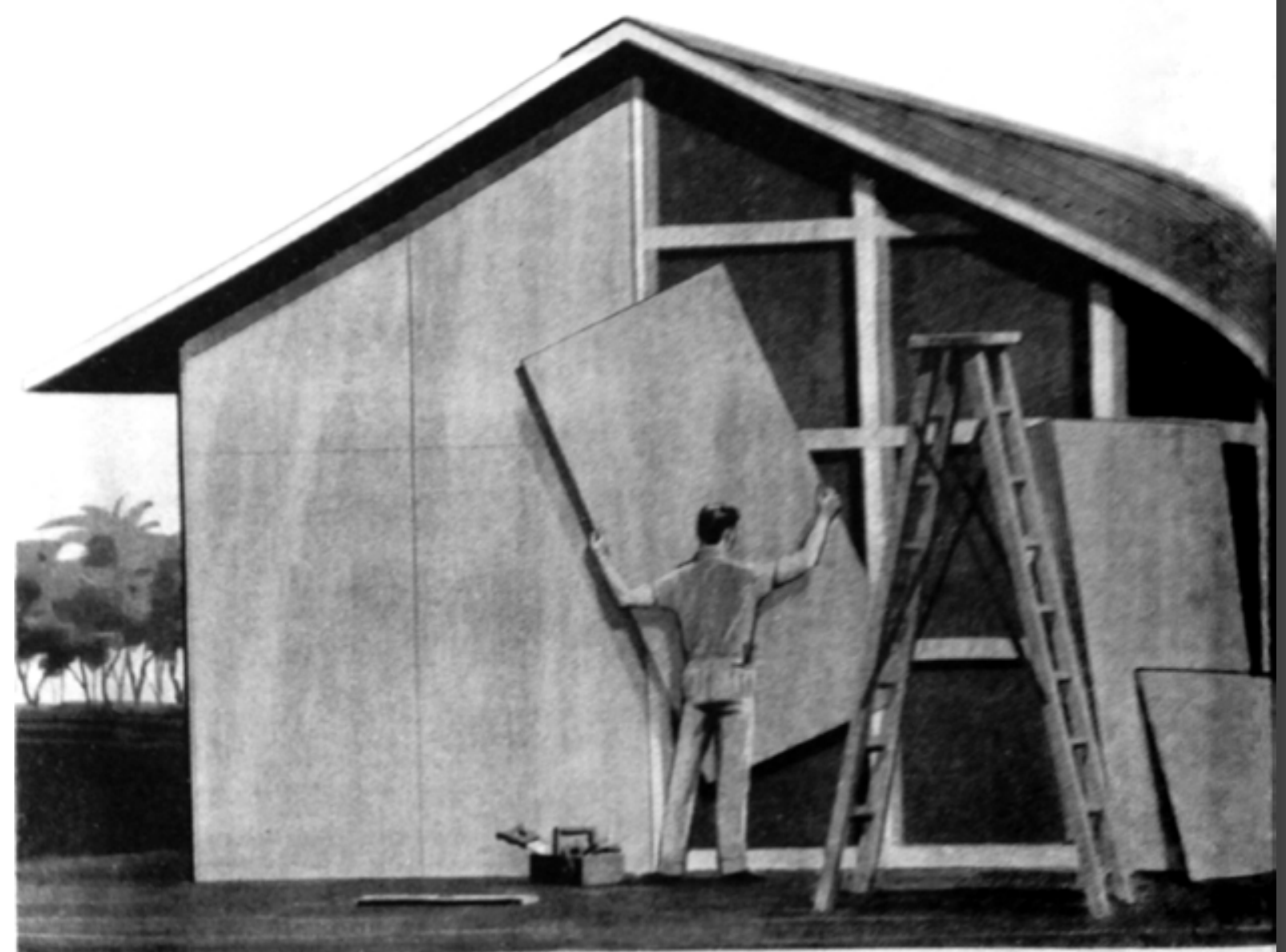

TELHA E COMPENSADO

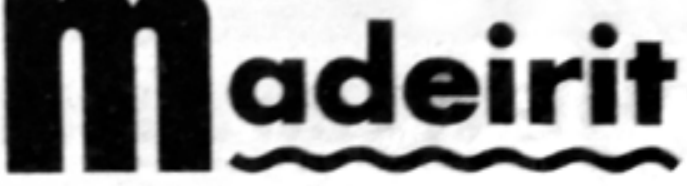

Produzidos por técnicos especializados, o Compensado e a Telha Madeirit sáo o que há de mais aperfeiçoado no campo de madeiras tratadas. Säo foitos com madeira escolhida e imunizada por impregnaçlo a vácuo e a pressalo, contra cupins, fungos e com retardantes de combustăo. Na ponta do lápis, nlio existe material mais económico: colocaçlo rápida e fácil (economiza tempo, milo de obra e madeiramento do telhado), grande durabilidade, maximo reaproveitamento.

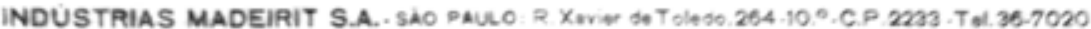

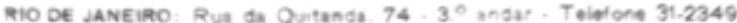

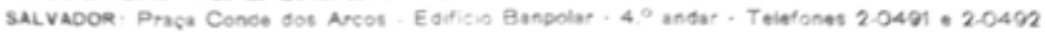

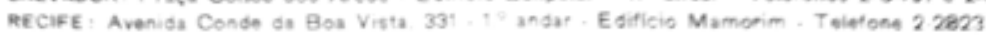

Publicidade de telhas e painéis em madeira compensada Madeirit.

O Dirigente Construtor. São Paulo, v. 2, n. 2, p. 50, dez. 1965. 


\section{Conclusão: as propostas PREGÁRIAS DE INDUSTRIALIZAÇÃO POSSÍVEL}


Ainda que através dos documentos oficiais, das ementas, existam somente menções bastante sutis ao modo como os docentes traziam a questão da industrialização da arquitetura para a sala de aula, encontramos ecos de algum debate que passou ao largo desses documentos oficiais. De algum modo, as referências que vimos do lado de fora reverberaram dentro da escola e chegamos ao final da década de 1960 e início da década de 1970 com alguns trabalhos discentes que talvez apontem isso.

O trabalho que acreditamos melhor exemplificar como a industrialização chegou na FAUUSP no final dos anos 1960 e como permeava as questões mais preocupantes para os arquitetos à época é o Trabalho de Graduação Inderdisciplinar de Gyorgy Troyko, de 1969. Em seu projeto "O problema da Habitação Popular em São Paulo" ${ }^{205}$, em que constata os dados de crescimento demográfico da cidade de São Paulo e a urgente necessidade de produção de habitação, Gyorgy Troyko propunha uma contraditória usina de pré-fabricados para a autoconstrução em mutirão de casas para trabalhadores que recebessem até 2 salários mínimos. Mesmo reconhecendo que a política habitacional da época não alcançava o segmento mais pobre da população - que não podia acessar o mercado formal de habitação, e por isso a proposta da autoconstrução - Gyorgy Troyko propunha que o acesso aos préfabricados fosse financiado pelo BNH e pelo FGTS, ainda que com taxas de juros revisadas e menores.

Consideramos o projeto de Gyorgy o reflexo dos discursos sobre as promessas da industrialização da arquitetura, a necessidade de se industrializar a produção de habitação, a única forma possível das camadas mais pobres da população acessar moradia e o único exemplo de financiamento de habitação que a nação conhecia. No entanto, é significativo que Gyorgy Troyko em sua vida profissional tenha sido o responsável por trazer instalar a empresa MUNTE, alemã de grandes peças industrializadas em concreto, no Brasil.

205 TROYKO, Gyorgy. O problema da Habitação Popular em São Paulo. TGI FAUUSP. São Paulo, 1969. Orientação não indicada. 
A partir dos anos 1970, outros formandos da FAUUSP também abordaram a industrialização em seus trabalhos de graduação, ora apresentando um repertório do que estava disponível, ora especulando como a industrialização poderia ser parte de uma política nacional para desenvolvimento tecnológico, ora na forma de propostas contraditórias que consideravam projetos para autoconstrução.

Entre outros exemplos, citamos o TGI de Sérgio Monteiro de Souza, "A posição do arquiteto na industrialização da construção civil’"206, de 1972, em que apresenta as definições do vocabulário básico da industrialização da construção civil (pré-fabricação leve, pesada, aberta, fechada, parcial), as vantagens de cada tipo de pré-fabricação e seu rebatimento em relação aos materiais e técnicas construtivas a que correspondem cada um. Apresenta a produção das empresa existentes à época, Engefusa, Oxford, Montreal, Cinasa, Rodrigues Lima, e conclui que a formação dos arquitetos deveria enfrentar o problema da industrialização da arquitetura, sem no entanto detalhar mais do que isso.

A partir do entendimento do que seria subdesenvolvimento (se um atraso no desenvolvimento ou se um produto do desenvolvimento), de como se dá processo de produção social do meio urbano na América Latina e das características da política habitacional do BNH à época, Antônio Carlos Santanna, em seu trabalho "Subdesenvolvimento: urbanização e industrialização da construção" ${ }^{207}$, de 1974, propõe que a construção civil seja industrializada através de uma política nacional de desenvolvimento tecnológico, acreditando que tal política se rebateria na melhor qualidade das edificações produzidas e na melhoria das condições de trabalho da mão-de-obra da construção civil - que portanto não teriam redução do seu custo de vida por conta da autopromoção de moradia. Apesar da proposta ingênua, Sant'Anna já entendia as implicações perversas da autoconstrução e não confundia seu papel inevitável com as possibilidades milagrosas da industrialização.

Por outro lado, o TGI de Cibele Bottin, "Autoconstrução" 208 , de 1976, propõe um contraditório projeto para um mutirão autoconstruido numa gleba de Taboão da Serra. Depois de explanar sobre as características da urbanização em São Paulo, sua específica concentração industrial e a expansão urbana periférica, justifica a necessidade daquele projeto pelo fato da autoconstrução ser tanto o processo predominante de construção das periferias

206 SOUZA, Sérgio Renato Monteiro de. A posição do arquiteto na industrialização da construção civil. TGI FAUUSP. São Paulo, 1972. Orientação de Abelardo Gomes de Abreu.

207 SANT'ANNA Jr, Antonio Carlos. Subdesenvolvimento: urbanização e industrialização da construção. TGI FAUUSP. São Paulo, 1974. Orientação de Paulo J.V. Bruna.

208 BOTTIN, Cibele. Autoconstrução. TGI FAUUSP. São Paulo, 1976. Orientador não indicado. 
como por ser um processo que só resulta em edificações precárias, e daí a necessidade de intervenção do arquiteto. Mesmo não fazendo sentido, o projeto prevê o uso de produtos industrializados, como laje pré-fabricada tipo "Prel"209, impermeabilizantes industrializados, comprados em qualquer loja de materiais de construção da periferia, e blocos de concreto. Apesar da contradição entre o projeto e uma edificação autoconstruida, o desenho estava adequado às forças produtivas disponíveis para a realização de um produto que seria consumido por uma população de baixa renda.

Os trabalhos dos estudantes sobre uma industrialização que dialogava com a autoconstrução, inclusive pela negação, como no trabalho de Sant'Anna, não seriam os únicos. Alguns trabalhos de arquitetos paulistas renomados à época, publicados nas revistas, também tentavam dar conta da questão da habitação por meio de projetos-modelo que consideravam a autoconstrução.

Um desses projetos é a proposta de Oswaldo Bratke para o problema habitacional de regiões mais pobres publicado na revista Acrópole ${ }^{210}$ em 1966 e que já tinha sido apresentada em 1962 à Comissão da Casa Popular, sob a Presidência de Franco Montoro, então Ministro do Trabalho. De maneira bastante ingênua, Bratke propunha a construção de pequenas casas (precárias) pré-fabricadas a serem construídas em etapas pelos próprios moradores por meio de ajuda mútua. A proposta ainda considerava que a própria mão-de-obra da população "beneficiária" do conjunto deveria ser contrapartida no pagamento da edificação. Ainda que involuntariamente, a proposta considerava a precarização da mão-de-obra daquela população que já era aviltada e que dificilmente poderia adquirir casa no mercado habitacional, como solução para a questão habitacional.

E, mesmo com projeto elaborado por um dos principais e mais celebrados arquitetos de São Paulo à época, a casa possui um aspecto externo e interno bastante pobre e medíocre: na primeira etapa de construção, a casa deveria se configurar nas paredes exteriores com cobertura, sem acabamentos ou divisórias internas, com a cozinha reduzida ao equipamento mínimo e um banheiro definitivo acessado por fora. A conclusão da casa, com divisórias e acabamentos, demoraria ainda ao menos duas etapas; enquanto isso, a família moraria numa edificação que mais se parecia com um barraco. Esse modelo parece que foi adotado como regra por nossas periferias.

\footnotetext{
209 Sigla da empresa "Prática, Resistente, Econômica e Leve", produtora de artefatos em concreto.

210 BRATKE, Oswaldo Arthur. Habitações populares. Acrópole. São Paulo, n. 335, p. 24-27, dez. 1966.
} 
Outro projeto foi elaborado por Paulo Mendes da Rocha e publicado também em Acrópole ${ }^{211}$, em 1967, em que se propunha a montagem a seco de elementos pré-fabricados, existentes e usuais à época, na produção de habitação popular, com uma tipologia mínima e com leiaute de ambientes muito parecido com a planta original do Conjunto Zezinho Magalhães. Este projeto também nos impressiona pelo aspecto e resultado final ser tão ordinário.

Conforme havia um imaginário sobre a industrialização da arquitetura que, no Brasil, parecia não se concretizar, especialmente em relação à solução do déficit habitacional, e conforme não encontravam um ambiente aberto para suas propostas, muitos arquitetos voltaram-se para o meio informal, para um "mercado" de autoconstrução, para lançar suas ideias.

Mas o projeto que, em nossa opinião, melhor traduz a concepção de industrialização para os docentes ${ }^{212}$ da FAUUSP naquele momento ainda é o que se empreendeu para a realização do Conjunto Zezinho Magalhães. Em Acrópole, Eduardo Corona defendiaa ${ }^{213}$ a industrialização da construção civil de forma estatal, único meio em sua opinião de sanar o déficit habitacional e, ao elogiar o projeto de Artigas e equipe, talvez estivesse traduzindo um sentimento que as pessoas do meio nutrissem em relação ao projeto: esperava-se que um projeto de tantas virtudes - que havia considerado não somente os aspectos técnicos e econômicos do construir, mas que tinha levado em conta os aspectos sociais da vida em conjunto no habitat e no meio urbano, considerando a proximidade de transporte, de escolas, de comércio, de equipamentos de lazer — se transformasse no paradigma de solução ao problema da habitação.

De fato se transformou no paradigma. Por um lado, o projeto original desconsiderou as questões de produção quando os arquitetos resolveram desenhar os componentes de concreto sem orientação do setor que já possuía expertise no assunto. Ao menos a historiografia do conjunto não aponta nenhuma referência nesse sentido. Quando perguntada sobre as opções de produtos industrializados disponíveis à época e que poderiam ter sido usados na construção, Maria Giselda Cardoso Visconti, uma das projetistas do conjunto, conta $^{214}$ que a

211 ROCHA, P.A.M. Unidade de habitação pré-fabricada 1967. Acrópole. São Paulo, n. 343, p. 43-45, set. 1967.

212 E por consequência para a comunidade da FAUUSP. O projeto foi elaborado por Vilanova Artigas e Paulo Mendes da Rocha, docentes da escola à época, com a colaboração de ex-alunos como Maria Giselda Visconti, Geraldo Puntoni, Arnaldo Martino e Ruy Gama. Fonte: ARTIGAS, J.B.V; PENTEADO, F; ROCHA, P.A.M; MARTINO, A.A; VISCONTI, M.G.C; NUNES, R; GAMA, R. Conjunto habitacional em Cumbica. Acrópole. São Paulo, n. 372, p. 32-37, abr. 1970.

213 CORONA, Eduardo. O conjunto habitacional de Cumbica. Acrópole. São Paulo, n. 348, p. 12, mar. 1968.

214 Em entrevista concedida em 09 de dezembro de 2015. 
equipe não estava interessada nas esquadrias ou nas instalações prediais, já disponíveis no mercado. O que interessava para a equipe era desenvolver os painéis em concreto, que não existiam ainda no Brasil à época (apesar de termos demonstrado o contrário no capítulo anterior).

Por outro lado, o conjunto se tornou o paradigma da política habitacional do governo estadual pois seu projeto não somente teve de ser adaptado para ser construído com processos convencionais no terreno em Guarulhos (Ficher, 1972), como foi adaptado para considerar a autoconstrução.

Ao mesmo tempo, e contraditoriamente, já havia um amplo mercado de produtos industrializados que contribuíam para a autoconstrução, e que foram por essa modalidade de provisão habitacional amplamente consumidos.

Se num momento anterior a industrialização parecia um conjunto de ferramentas e técnicas que possibilitariam a produção em massa de habitação para nos salvar do caos urbano e da falta de habitações, agora ela voltava a tomar a sua forma monstruosa de âmbito de exploração e precarização do trabalho alheio. Exatamente porque havia a industrialização de componentes de construção é que a autopromoção de habitação foi possível desde meados do século XX nas áreas urbanas do Brasil, uma vez que qualquer pessoa sem treinamento específico é capaz de utilizá-lo.

Ao contrário do que aponta Maricato (1976), materiais como a laje pré-fabricada - talvez o produto mais veiculado nas revistas durante o período estudado - não penetraram a autoconstrução pelo fato da madeira ter tido seu preço aumentado mas pelo fato da própria laje pré-fabricada ser uma opção tecnológica mais viável e disponível para a mão-de-obra não qualificada da auto-construção. O telhado de madeira pressupõe um conhecimento de carpintaria para ser executado e, a depender das condições de execução, o madeiramento pode ficar com aspecto precário e acumular sujeira e vetores de doença, como pombos e ratos; ao passo que a laje pré-fabricada, era conhecida da população de baixa-renda empregada em canteiros formais que já as utilizavam ao menos desde a década de 40. As lajes pré-fabricadas oferecem a possibilidade de ampliação da casa, tanto na horizontal quanto na vertical, enquanto o telhado de madeira necessita de intervenção para ser estendido. Além de estar disponível no varejo, a laje pré-fabricada possui o aspecto de modernidade do concreto e das casas da classe média, projetadas por arquitetos e veiculadas nas revistas, que também as utilizavam. 
No primeiro capítulo, apresentamos alguns episódios em que os arquitetos e profissionais que se relacionavam com a FAUUSP discutiam a industrialização da arquitetura como sendo um componente da perspectiva do desenvolvimento nacional. Nessa perspectiva, o arquiteto teria um papel social, político-profissional a desempenhar: ele seria o agente que, mobilizando seus conhecimentos sobre as necessidades da sociedade e sobre o bom desenho, integraria o conjunto formado pelo empresariado industrial (a indústria) e os construtores (o operário) na condição de mestre.

Algumas vezes, os arquitetos até mesmo se arriscavam a ensaiar a pré-fabricação de alguns elementos em seus pequenos canteiros para habitação da classe média - a exemplo da prática profissional de Carlos Millán - ou se debruçavam em criar e detalhar componentes, numa atitude voluntariosa, para a economia de uma obra de habitação popular.

Motivada tanto pela insatisfação de sua comunidade com a presença do ensino politécnico como pela oportunidade de consolidar a proposta de ensino da arquitetura moderna, a FAUUSP realiza a Reforma Curricular de 1962 em implanta a Sequência de Disciplinas de Desenho Industrial, também no embalo que se seguiu ao entusiasmo com o desenvolvimentismo brasileiro do final dos anos 1950. Os registros da reforma curricular e das atividades de desenho industrial desenvolvidas, pela primeira vez, pelos estudantes apontam que a reforma seria uma contribuição ao problema colocado pelo desenvolvimento nacional.

Conforme apresentado no segundo capítulo, aquelas atividades de desenho industrial estavam circunscritas, ainda que numa proposta legítima, a elaboração de projetos para bens de consumo. A FAUUSP passava a formar um profissional que possuía perfil para o trabalho na indústria de bens. Mas as disciplinas de projeto de arquitetura, por outro lado, não só não consideravam o desenho industrial como um aspecto importante na formação de um profissional projetista de arquitetura, como muitas vezes proibiram que os estudantes considerassem a industrialização do projeto. Seria possível que essa proibição refletisse um entusiasmo dos estudantes com o tema - inclusive levado espontaneamente na forma de tese para um Encontro Internacional de Professores e Estudantes de Arquitetura que aconteceu em Cuba - por um lado e um docente com pouco traquejo para o ensino de desenho industrial do outro?

Ao mesmo tempo em que nota-se um vazio sobre o tema da industrialização da arquitetura na vida profissional dos docentes de projeto e em suas aulas, o tema da industrialização estava 
latente na escola. Ao menos Ariosto Mila mobilizava o tema da industrialização da arquitetura, ainda que do ponto de vista de repertório e não de projeto, já nos anos 1960.

Se Ariosto Mila e os estudantes já mobilizavam um repertório de produtos e possibilidades de industrialização, que repertório era esse?

No terceiro capítulo apresentamos um debate que já acontecia do lado de fora das salas de aula, promovido por muitos daqueles arquitetos que ainda desejavam que a industrialização da arquitetura fosse um componente da produção de habitação social e do desenvolvimento nacional. Enquanto isso, esse debate era intercalado ora por farta publicidade de produtos industrializados para a construção civil, ora pelas viagens e pelos congressos, pelos quais os nossos personagens tomavam contato com a produção industrializada estrangeira.

Até esse momento, parecia que a industrialização da arquitetura demoraria para se concretizar. Com o fracasso das políticas habitacionais oficiais, a industrialização é mobilizada também junto do tema da autoconstrução, inclusive pelos arquitetos. Era a autoconstrução a única modalidade de provisão habitacional das populações mais pobres.

E aquela arquitetura possível era possível exatamente por que a industrialização cumpriu o destino traçado pelos arquitetos modernos: ela já estava disponível em catálogos, em mostruários e nas lojas em cada esquina das nossas periferias. Balaústres de argamassa, lajotas cerâmicas, sacos de cimento, blocos para alvenaria e lajes pré-fabricadas disponíveis no varejo para que qualquer pessoa com pouco ou nenhuma qualificação como construtor pudesse construir sua casa. 
Diante do exposto, sentimos que o empreendimento năo deve ser encarado como operaçóo lu. crativo, executado por contraton. tes especializados, pois o lucro almejado está no baratecmento da obro e nos beneficios indire. tos que elo produzir.

A participaçōo díreta do interes. sado, dentro de suas possibilidades, na execuçăo dos trabalhos, cuja tônica é a ajuda mútua, abre a êle compo de conhecimentos no contato com instrutores moni. torss e os raros operários qualifi. cados necessários, despertando co mesmo tempo o interêsse pelo prática de cooperativismo.

O terreno destinado ao conjunto deve sar à distáncia tal que nōo invalide o principio exposto, que \& de oproveitamento do mố-de. obra de todos os usuórios em suas horas de folga. O valor dessse terreno deve ser opreciado em funçăo de transporte, preço ini. cial, facilidade de serviços públi. $\cos$ e topografia.

Năo devem entrar em cogitaçác terrenos formados por aterros. turfa ou cuja toxa de carga sejo inferior a $500 \mathrm{~g} / \mathrm{cm}^{2}$, e nem aquêles com nivel freático superior o $1,20 \mathrm{~m}$ abaixo do piso das casas (piso $0,15 \mathrm{~m}$ acima do solo). E considercada boa a topografia de perfil inferior a $5 \%$ para as zonos edificande.

E necsssário um capital inicial de financiamento, o qual bbviamen. te será tanto menor, quanto mais rópido fôr o ciclo das constru. şóes. Esse capital deve corresponder ao valor do construçōo da infraestrutura do conjunto, golpóo para oficina-escola artesanal e sua aparelhagem indispensável, a qual no futuro abrigará tam. bèm uma cooperativa e a cons. trução dos carcassas, e o minimo admissivel para constituiç̧ōo de uma caixa de empréstimos para obras de conclusáo que serỗo feitas a longo prazo.

- conjunto deve ser operado como um condominio, havendo apenas cessóo de direitos de uso para os lotes residenciais, e como condominio todas as despesas com as obras comuns, inclusive as de seguro coletivo das unidades. As despescos de manutençōo serāo divididas proporcionalmente.

O sindico deve ser, de preferên. cia, o chefe da cooperativa-escola artesonal.

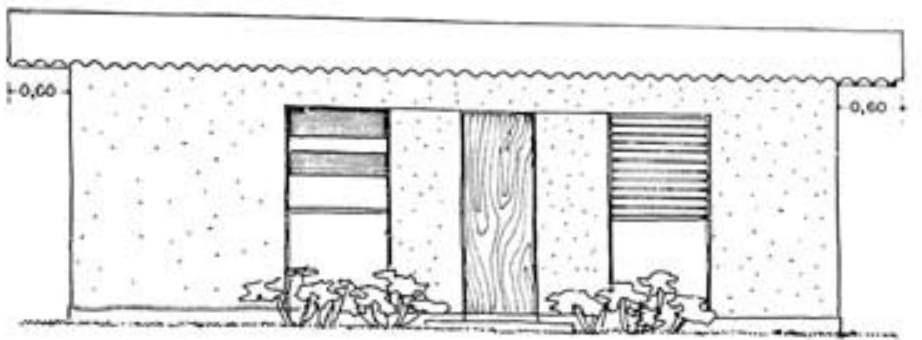

Elevoşăo principal
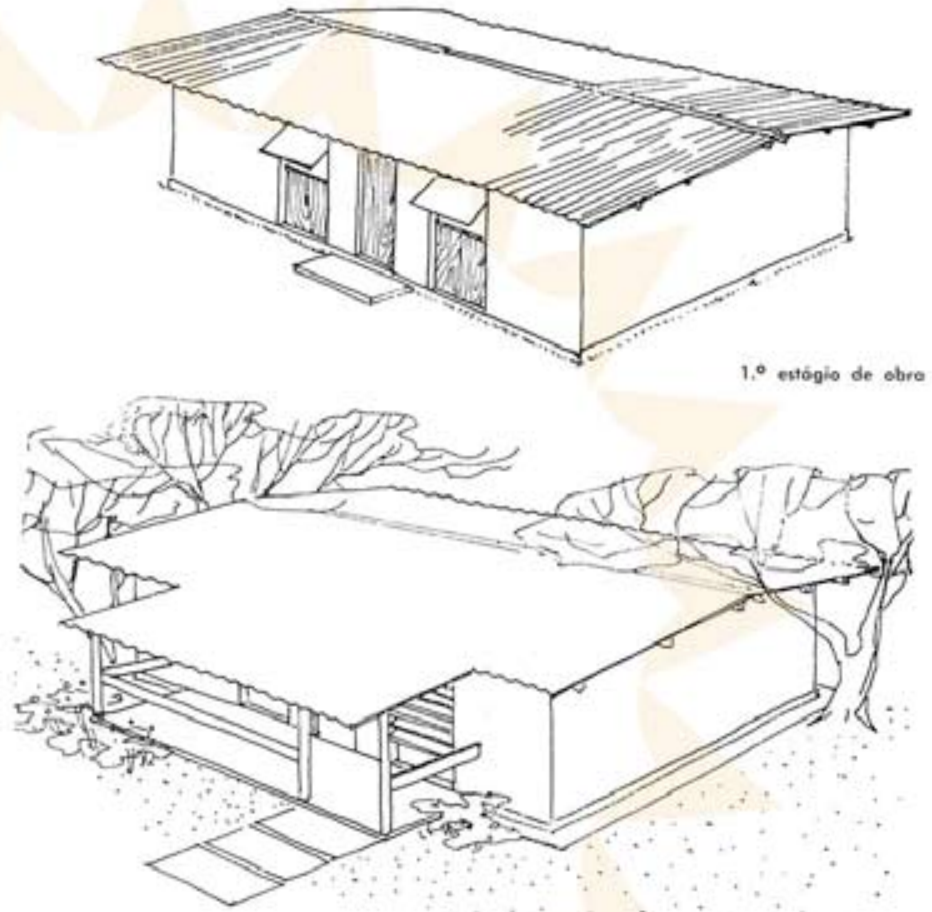

Enógio final de obra

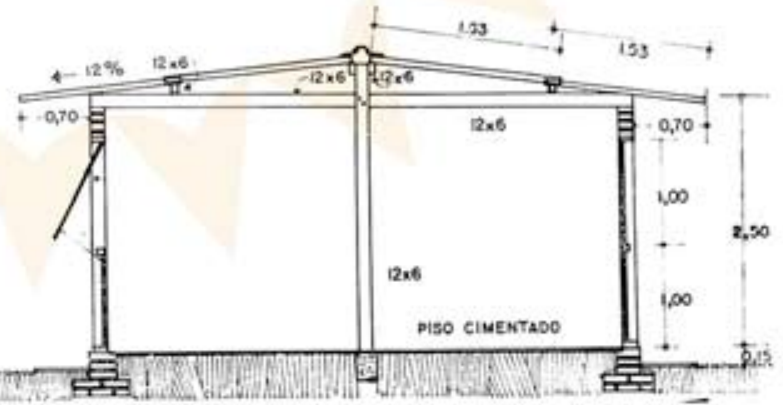

Corte

Artigo sobre proposta do arquiteto Oswaldo Bratke para produção de habitação popular: industrialização de componentes para autoconstrução em etapas.

BRATKE, Oswaldo Arthur. Habitações populares. Acrópole. São Paulo, n. 335, p. 24-27, dez. 1966. 

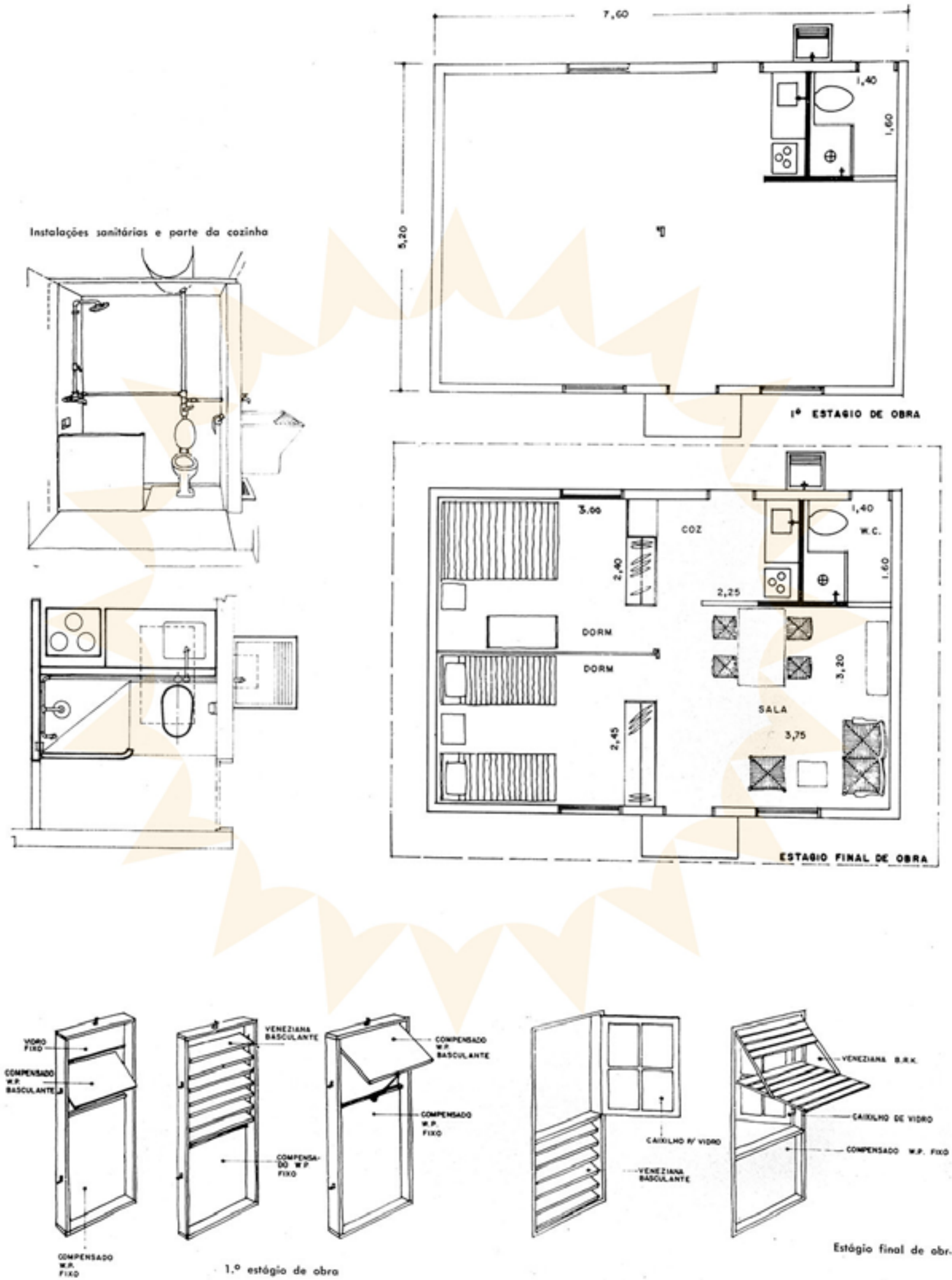

1,0 estbgio de obro 


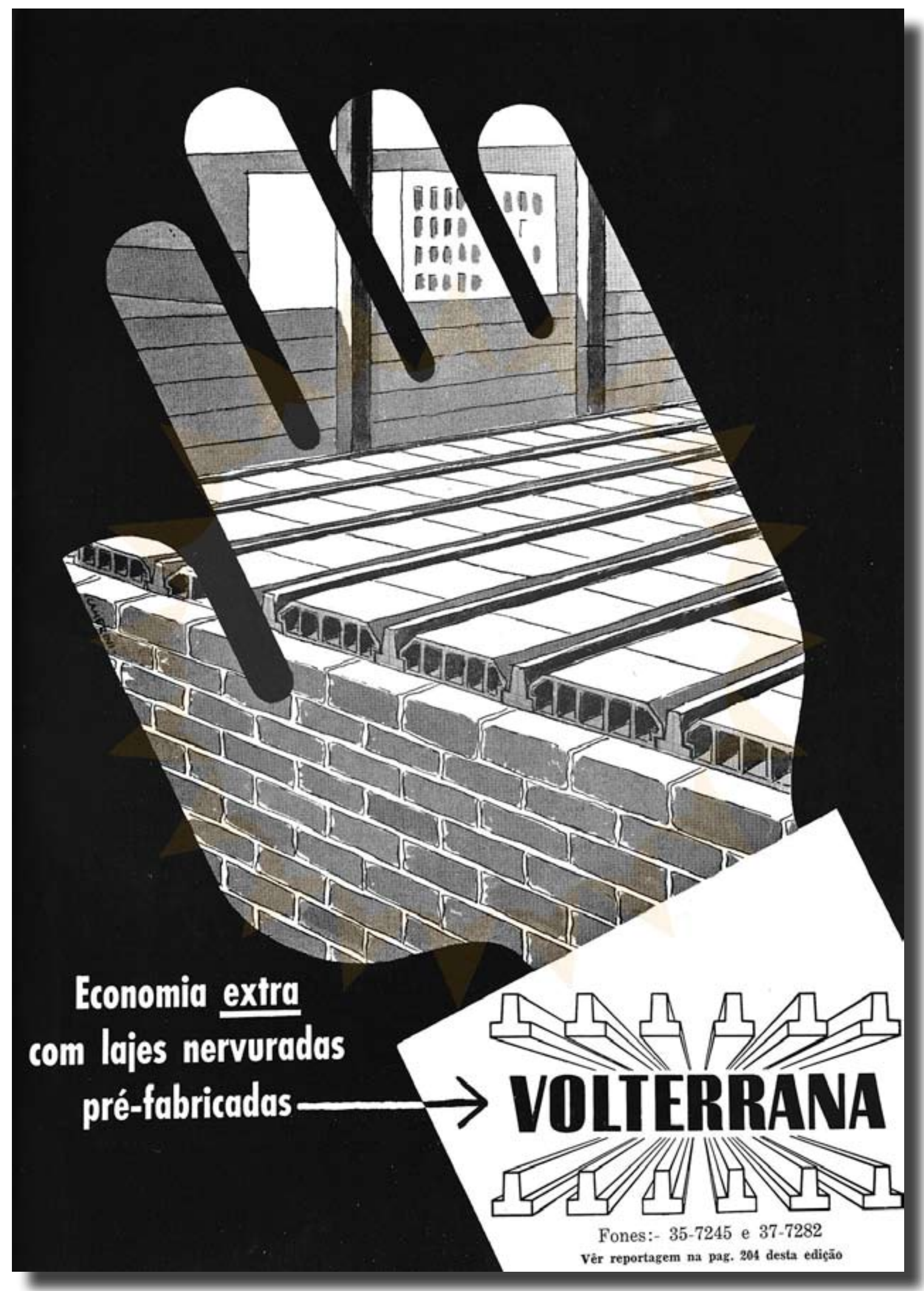

Publicidade das lajes nervuradas pré-fabricadas pela empresa VOLTERRANA.

Acrópole. São Paulo, n. 209, fev. 1956. 


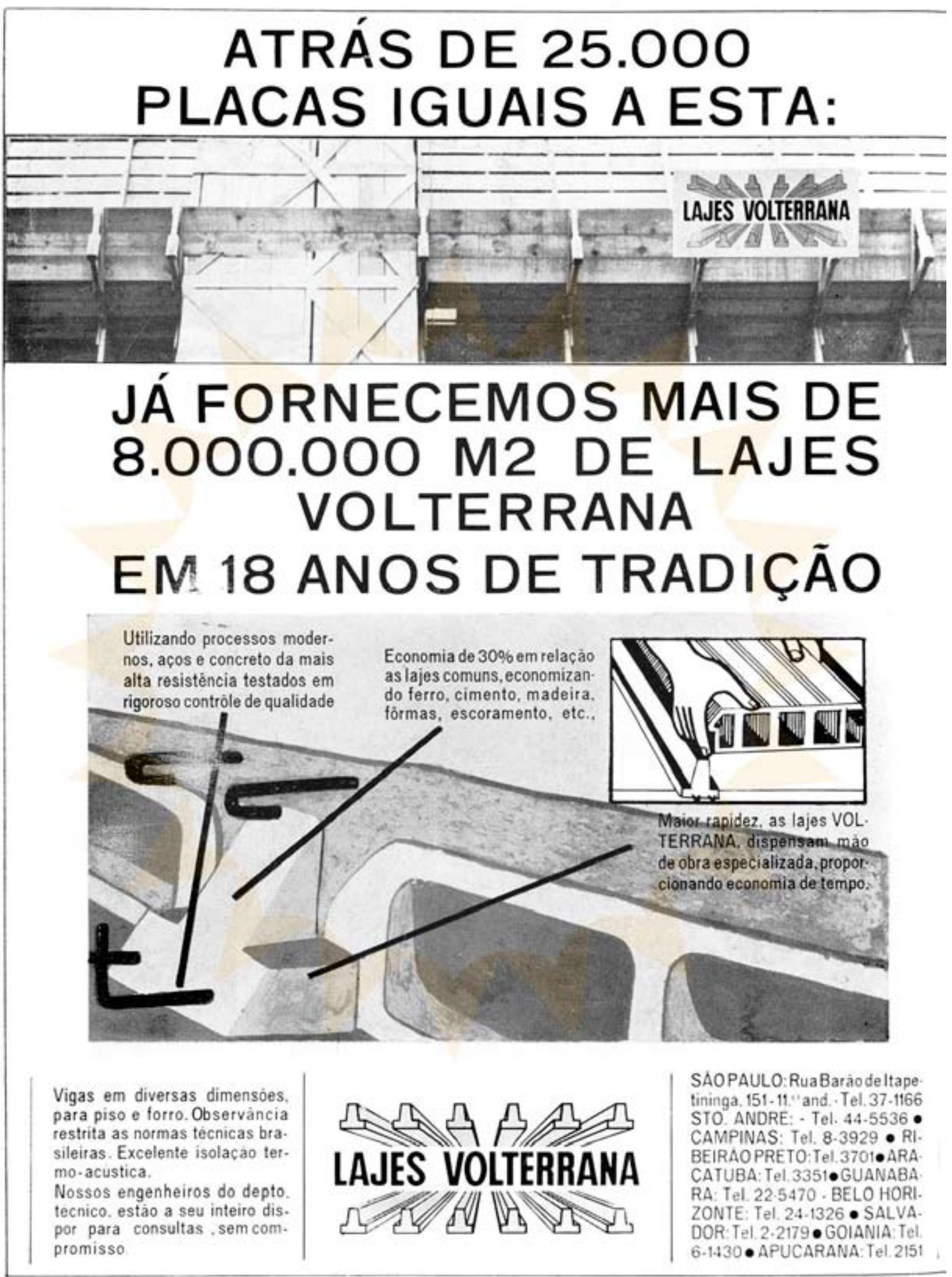

Publicidade das Lajes VOLTERRANA.

Acrópole. São Paulo, n. 360, abr. 1969. 


\section{sact \\ LAJES VOLTERRANA \\ representam economia múltipla}

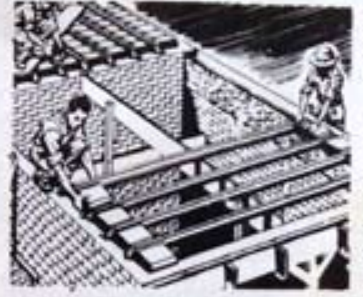

CUSTAM MENOS DO QUE AS LAJES COMUNS madeira (tormas e caibrow) que entram na preparaçào dsa lajes de ooncreto maeico. Lajes VOt. diminuem sensivel mente o custo do lajeamento.

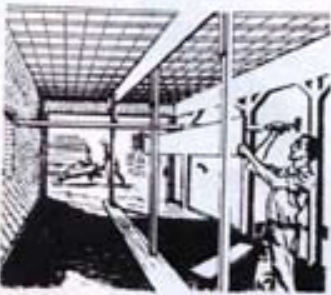

REDUZYM O ESCORAMENTO $x$ FORMAs

Uma diniea escora - dividindo o vio em duan partes - tecoora. mento suficiente para as Lajes VOLTERTLANA. N3e sto necesed. rias tôrman te madeirs, pois. proprio material serve de forma.

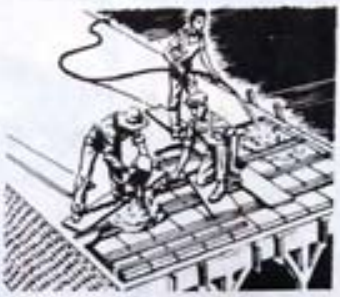

DCONOMIZAM 70\% NA MX̃o $\mathrm{DE}$ OBม⿵冂卄

Laje VOLTERTANA nato exigem mato do obra cojpotaliesdat nem terem trabalhado nems tar e capear cetrca de $100 \mathrm{~m}$, por alo da confusden.

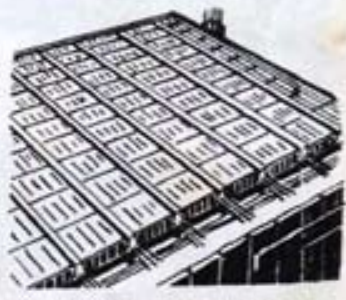

- serviço de ansaç̃o $x$ ABOLIDO

Pois o parte constituinte dn vi gota As construcbes com Lajes VOLTERRANA sho desafogada: Tudo fica mais thell.

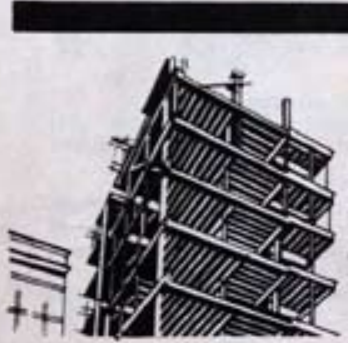

APRESSAM A ENTREOA DAS

De theil colocaçato, Lajes voL TERRANA encurtam o prazo de conclualo do lajeamento, posai. bilitando obras prontas em tem po muite menor

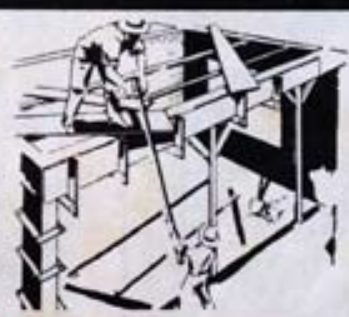

sio MAIs LEVEs: $100 \mathrm{~K}$ MENOB POR M

Lajes VOLTERRANA têm quase a metade do peét das lajes co. muns de concreto macigo, o que racilta en trature aliviando peso da eetrutura, aliviando

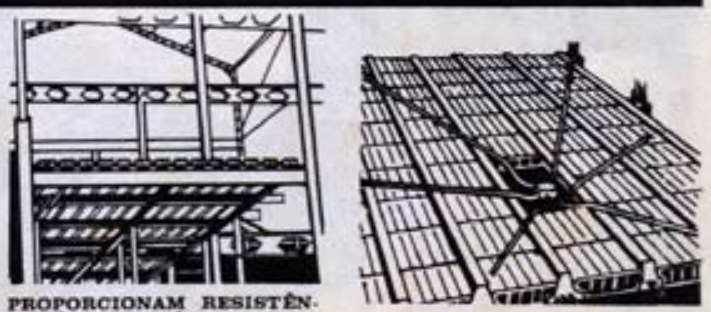

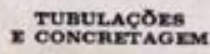
MAN OTIMA ATE $2.000 \mathrm{Kg}$ PON ÇO TERMO-ACUBTICA

Apenar do sua levezs natural. an Laje VOLTERRANA oferncem a mesma resiatencia que as peaa. Grapas ao colchso de ar contis. nas Laje VOLTERTANA, estat asseguram excelente isolagia
termo-acdatica entre of pisom.
Nac ha problemas para a insta. VOLTERRANA suas dimenode to pas lajes comuns $\mathrm{B}$ ta jel quat. TERRANA Niznificam cambetm grande coonomia de concreto jos trankportado e aplicad

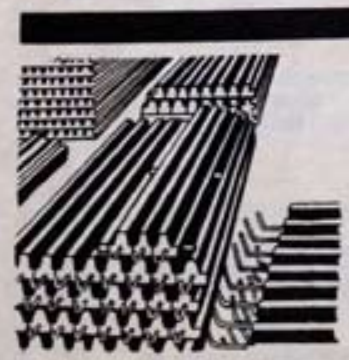

GRANDE ESTOQUE: NTRECAS RAPIDA
E PONTUAIS

Entoque permanente, en medi. das variaveis de $10 \mathrm{em} 10 \mathrm{em}$, as. necuram entregs imediata. Bi. tamos apareithadou a wuprit as trutores de quelener porte do pain.

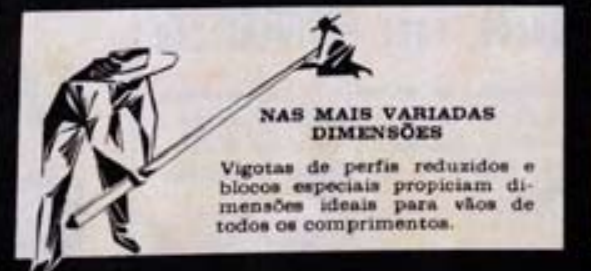

O CUSTO EMPATA COM A PREvisXo

E hoje em dia laso e lucro extra. Pelas vantageas que apreseatam.

Lajes VOLTERTANA proporoionam real oconomia de $30 \%$ ne cuato total. do lajeamento

ת ת. Paulo: rua Barăo de Itapetininga, 151 - $11 \%$. - fones: IAES VOLTEPRAMA 22.5470 e 42.3504 - B. Horizonte: rua slo Paulo, 893 LAJES V0 IERhAAA - 8." - fone: 4-1326 - Reelfe: rua Floriano Peixoto, 780 - 2, - fone: $43-785$ - Niteról: av. Amaral Peixoto, 370

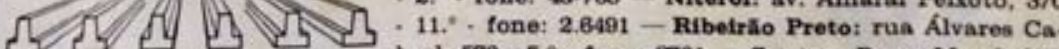
bral, 576 - 5." - fone: 3701 - Santos: Praca Maus, 29 3." - fone: 2-7007 - Camplnas: rua Campos Salles, 890

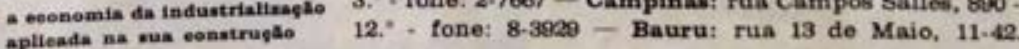

Publicidade das lajes pré-fabricadas Volterrana.

O dirigente construtor. São Paulo, v. 1, n.1, p. 03, nov. 1964. 
REFERÊNGIAS BIBLIOGRÁFICAS 
ACRÓPOLE. São Paulo: Max Gruenwald \& Cia, 1938-1971. Acesso em: 08 ago. 2014. Disponível em: htp://www.acropole.fau.usp.br/

ALMEIDA, Paulo de Camargo e. A função social do arquiteto. Tese apresentada a FAUUSP para o concurso de provimento de catedrático da Cadeira 16 - Composição de Arquitetura - Pequenas Composições em maio de 1956. São Paulo, 1956. Mimeo

ALMEIDA, Paulo de Camargo e. Industrialização da construção. São Carlos: EESC-USP, 1971.

ARTIGAS, J.B.V. Depoimento: entrevista a Lívia Pedreira, s/d. in XAVIER, Alberto. Depoimento de uma geração: arquitetura moderna brasileira. Organizado por Alberto Fernando Melchiades Xavier. Prefácio de Julio Katinsky. São Paulo : Cosac \& Naify, 2003.

ARTIGAS. J.B.V. Contribuição para o relatório sobre o ensino de arquitetura, UIA - UNESCO, 1974 in SINOPSES: Memória. São Paulo: FAUUSP, Edição Especial, 1993. ISSN: 0101-7225.

AYMONINO, Carlo. La vivienda racional. Barcelona: Gustavo Gili, 1973.

BARETS, JEAN. Industrialization du Batiment. Téchniques \& Architecture. Paris, n. 4, mai-juin 1965. Edição especial para o $8^{\circ}$ Congresso da UIA. Tradução Paulo J.V. Bruna.

BOTTIN, Gibele. Autoconstrução. TGI FAUUSP. São Paulo, 1976. Orientador não indicado.

BRASIL. Decreto-lei n. 7918, de 31 de agosto de 1945, Dispõe sobre a organização da Faculdade Nacional de Arquitetura da Universidade do Brasil.

BRASIL. Lei Federal 4.4494, de 25 de novembro de 1964. Regula a locação de Prédios Urbanos.

BRUNA, Paulo Júlio Valentino. Arquitetura, industrialização e desenvolvimento. São Paulo: Edusp: Perspectiva, 1976.

BUZZAR, Miguel Antonio. Foão Batista Vilanova Artigas: elementos para a compreensão de um caminho da arquitetura brasileira, 1938-1967. São Paulo: Unesp:Senac São Paulo, 2014.

CARAMELO. São Paulo, Gfau - FAUUSP, outono 1993, n.6, pág. 9-22. Editorial. ISSN 0104-0251

CATÁLOGO Brasileiro da Construção. São Paulo: IAB-SP/ Editora e Consultoria Industrial CING, 1962.

CATÁLOGO Brasileiro da Construção. São Paulo: IAB-SP/ Editora e Consultoria Industrial CINC, 1965.

CERÁVOLO, Ana Lúcia. Paulo de Camargo e Almeida: arquitetura total na trajetória de um arquiteto brasileiro. Orientador Prof. Dr. Carlos Roberto Monteiro de Andrade. Dissertação de mestrado. São Carlos: EESC-USP, 2000. 
GERÁvOLO, Ana Lúcia. Projeto para o Morro Santo Antônio - 1938: as concepções urbanísticas de Paulo de Camargo e Almeida In ANAIS do $5^{\circ}$ Seminário de História da Cidade e do Urbanismo “Cidades:

temporalidades em confronto" Uma perspectiva comparada da história da cidade, do projeto urbanístico e da forma urbana. Campinas: FAU-PUC, s/d. Acessado em 11 de outubro de 2015. Disponível em <http://unuhospedagem.com.br/revista/rbeur/index.php/shcu/article/download/591/567>.

COLLINS, F Thomas. Building with tilt-up. Berkeley: S.N., 1967.

. Design of tilt-up buildings. Eugene: S.N., 1963.

. Manual of tilt up construction. Berkeley: S.N., 1965.

Congres de L'union Internationale des Architectes, $7^{\circ}$, 1963. L'Architecture dans les pays en voie de développement. $7^{\text {oo }}$

Congres de L'union Internationale des Architectes. Habana : UIA, 1969.

Congres de L'union Internationale des Architectes, 9, 1967. Rapport principal: rapports partiels; resume de

l'enquete. $9^{\circ}$ Congres de L'union Internationale des Architectes. Prague : UIA, 1967.

Congresso Brasileiro de Arquitetos, 1º 1945. Anais. São Paulo: IAB, 1945.

Congresso Brasileiro de Arquitetos, 4, 1954. Anais. São Paulo: IAB, 1954.

Congresso Brasileiro de Arquitetos, 6. 1966. Anais. Salvador: IAB, 1966.

Congresso da União Internacional de Arquitetos, $7^{\circ}, 1963$. A arquitetura nos países em via de desenvolvimento. Anais. Havana, Cuba, setembro de 1963. Volumes 1 e 2.

Congresso Nacional de Arquitetos, 3º 1953. Anais. Belo Horizonte: IAB, 1953.

COnStantinO, Regina Adorno. A obra de Abelardo de Souza. Dissertação de mestrado. São Paulo, FAUUSP, 2004. Orientação de Lúcio Gomes Machado.

DEDECGA, Paula Gorenstein. Sociabilidade, crítica e posição: o meio arquitetônico, as revistas especializadas e o debate do moderno em São Paulo (1945-1965). Dissertação de mestrado. São Paulo, FAUUSP, 2012. Orientação de José Tavares Correa de Lira.

DEL GARLO, Ualfrido. Desempenho de edifícios, ensino de tecnologia da arquitetura, certificação ambiental de edifícios. Entrevista concedida a D. Duarte, J.G.S. Gonçalves e R.C. Kronka Mülfarth In PÓS - Revista do Programa de Pós-Graduação da Faculdade de Arquitetura e Urbanismo, São Paulo, n. 22, p. 10-24, dez. 2007.

DIAMANT, R.M.E. Industrialised building: 50 international methods. London: Iliffe, 1964.

DIAS, Michele Aparecida Siqueira. Dimensões do morar moderno em Guarulhos: a trajetória do Conjunto Habitacional Zezinho Magalhães Prado, CECAP (1966-1972). Relatório de Iniciação Científca. Guarulhos:

EFLCH/UNIFESP, 2013. Orientação de Fernando Atique.

DORFMAN, César. Havana 63. Porto Alegre: Movimento, 2013.

ESTUDO n.10. Relatório da coordenação industrial para o plano habitacional (CIPHAB). Sem local: GTH-BNH, 1967.

FAGGIN, Carlos Augusto Mattei. Carlos Millán: uma leitura de alguns projetos escolhidos in Revista Sinopses. São 
Paulo: FAUUSP, n.10, 1987.

Carlos Millan: itinerário profissional de um arquiteto paulista. Tese de Doutorado. São Paulo: FAUUSP, 1992. Orientação de Marlene Yurgel.

FAUUSP. Desenho industrial 1962. São Paulo: FAUUSP, 1963 (a).

FAUUSP. Programa proposto para 1953. São Paulo: FAUUSP, Serviço de Publicações, 1953.

FAUUSP. Programa proposto para 1956. São Paulo: FAUUSP, Serviço de Publicações, 1956.

FAUUSP. Programa proposto para 1957. São Paulo: FAUUSP, Serviço de Publicações, 1957.

FAUUSP. Programa proposto para 1959. São Paulo: FAUUSP, Serviço de Publicações, 1959.

FAUUSP. Programa proposto para 1961. São Paulo: FAUUSP, Serviço de Publicações, 1961.

FAUUSP. Programa proposto para 1962. São Paulo: FAUUSP, Serviço de Publicações, 1962.

FAUUSP. Programa proposto para 1963. São Paulo: FAUUSP, Serviço de Publicações, 1963 (b).

FAUUSP. Programa proposto para 1964. São Paulo: FAUUSP, Serviço de Publicações, 1964.

FAUUSP. Programa proposto para 1965. São Paulo: FAUUSP, Serviço de Publicações, 1965.

FAUUSP. Programa proposto para 1966. São Paulo: FAUUSP, Serviço de Publicações, 1966.

FAUUSP. Programa proposto para 1967. São Paulo: FAUUSP, Serviço de Publicações, 1967.

FAUUSP. Programa proposto para 1968. São Paulo: FAUUSP, Serviço de Publicações, 1968.

FAUUSP. Relatório das Atividades de 1962. São Paulo: FAUUSP, 1963 (c). Setor de Publicações

FERNÁNDEZ ORDÓÑEZ, Jose A . Prefabricacion: teoria y pratica. Seminario de prefabricacion. Barcelona: Ed Tecnicos, 1974. Volumes 1 e 2.

FICHER, Sylvia. Os arquitetos da Poli: ensino e profissão em São Paulo. São Paulo: EDUSP, 2005.

FICHER, Sylvia. Subsídios para um estudo do Conjunto Habitacional Zezinho Magalhães Prado. Trabalho de graduação interdisciplinar. São Paulo: FAUUSP, 19?? (c.1972). Mimeo.

FIZ, Simón Marchan (org). La architectura del Siglo XX: textos. Madrid: Alberto Corazon, 1974.

Fórum: o percurso do ensino na FAU. Revista Caramelo. São Paulo, Gfau - FAUUSP, outono 1993, n.6, pág. 9-22. Editorial.

GFAU. Corredor das humanas. São Paulo: Gfau - FAUUSP, 2009.

GFAU. Textos sobre o ensino de arquitetura. Textos de Mário Wagner Vieira da Cunha; Luís Saia; João Batista Vilanova Artigas; Lina Bo Bardi. São Paulo: Gfau - FAUUSP, 1956. Mimeo.

GFAU. Universidade de São Paulo Faculdade de arquitetura e urbanismo. São Paulo: Gfau-FAUUSP, set. 1963.

GRINOVER, Lúcio. Sequência de Desenho Industrial: unidade de ensino alternativo do $4^{\circ}$ ano, $2^{\circ}$ semestre de 1968. São Paulo, FAUUSP, 1968. Mimeo. 
GROPIUS, Walter. Industrialização da construção. In FIZ, Simón Marchan (org). La architectura del Siglo XX: textos. Madrid: Alberto Corazon, 1974, p. 34-36.

Trabalho prévio sistemático para a construção racional. In FIZ, Simón Marchan (org). La architectura del Siglo XX: textos. Madrid: Alberto Corazon. p. 162-164.

GUILLÉN, Mauro F. The Taylorized Beauty of the Mechanical: Scientific Management and the Rise of the Modernist Architecture. New Jersey: Princeton University Press, 2009.

Indústria e Arquitetura IN: Congresso Brasileiro de Arquitetos, 8, 1969. Anais. Porto Alegre: IAB, 1969.

KONCZ, Tihamer. Manual de la construccion prefabricada: con elementos de hormigon armado y de hormigon pretensado, construccion. Madrid: Blume, 1968.

KOURY, Ana Paula. Arquitetura construtiva: proposições para a produção material da arquitetura contemporânea no Brasil. Tese de doutorado. São Paulo: FAUUSP, 2005. Orientação de Nestor Goulart Reis Filho.

KRUSHEV, Nikita. Remove Shortcomings in Design, Improve Work of Architects IN OCKMAN, Joan (org.). Architecture Culture 1943-1968. A documentary anthology. Nova Iorque: Rizzoli, 1993. p. 185-188.

LE CORBUSIER; JEANNERET, Pierre. Análisis de los elementos fundamentais en el problema de la "vivienda mínima”, 1929. In AYMONINO, Carlo. La vivienda racional. Barcelona: Gustavo Gili, 1973, p. 126-138.

LEON, Ethel. IAC Instituto de Arte Contemporânea: Escola de Desenho Industrial do MASP (1951-1953), primeiros estudos. Dissertação de mestrado. São Paulo, FAUUSP, 2006.

MARICATO, Ermínia T.M. Autoconstrução, a arquitetura possível.

MATERA, Sérgio. Carlos Millan: um estudo sobre a produção em arquitetura. Dissertação de Mestrado. São Paulo: FAUUSP, 2005. 440 p. Orientação de José Eduardo de Assis Lefévre.

MAY, Ernst. A habitação mínima para a existência. In FIZ, Simón Marchan (org). La architectura del Siglo XX: textos. Madrid: Alberto Corazon, 1974, p. 195-199.

MELLO, João Manuel Cardoso de; NOVAIS, Fernando A. Capitalismo tardio e sociabilidade moderna In NOVAIS, F. A.; SCHWARCZ, L. M. (org). História da vida privada no Brasil. São Paulo, Cia das Letras, 1998.

Volume 4: Contrastes da intimidade contemporânea; organizado por Lilia Moritz Schwarcz.

MERKLE, Judith A. Management and Ideology: the Legacy of the Internacional Scientific Management Movement. Berkeley: University of California Press Ltd, 1980.

MIGUEL, Jair Diniz. Arte, ensino, utopia e revolução. Os ateliês artísticos Vkhutemas/Vkhutein (Rússia/ URSS, 1920-1930). Tese de doutorado. São Paulo: FFLCH-USP, 2006. Orientação do Prof. Dr. Marcos Silva.

MILA, Ariosto (et all). Projeto do curso de racionalização e industrialização da construção. São Paulo: FAUUSP, s/d. Mimeo.

MILA, Ariosto. A Cadeira de Construções Civis no ensino de Arquitetura In: Congresso Brasileiro de Arquitetos, 4º, 1954. Anais. São Paulo: IAB, 1954, p. 225.

MILA, Ariosto. A técnica de construção no problema da habitação. Tese apresentada para o Concurso da Cátedra 6 - 
Construções I. São Paulo: FAUUSP, 1967.

MILA, Ariosto. Edificio. São Paulo: FAUUSP, 19?? Mimeo.

MILLAN, Carlos Barjas. O ateliê na formação do Arquiteto. 1963. in Revista Sinopses - Memória. São Paulo:

FAUUSP, 1993. Pág. 166-176. Edição Especial.

MOKK, László. Prefabricated Concrete for Industrial and Public Structures. Budapest: Akadémiai Kiadó, 1964.

MOM - Morar de outra maneira. A história da habitação brasileira contada nas revistas especializadas. Projeto de pesquisa do Departamento de Projetos da Escola de Arquitetura da UFMG. Disponível em

http://www.mom.arq.ufmg.br/mom/. Acesso em 02 de novembro de 2014.

NEUFERT, Ernest. Arte de proyectar en arquitectura: fundamentos normas y prescripciones sobre construccion. Barcelona: Gili, 1945.

Industrializacion de las construcciones: manual de la construccion racional con medidas normalizadas.

Barcelona: Gili, 1965.

. Manual del styropor: aislamiento en los edificios desde el p unto de vista de los arquitectos descrito como ejemplo / Ernst Neufert ; [Adapt] Buenaventura Bassegoda. Barcelona : Herder, 1970.

NOGUEIRA, Breno Cirino. Contribuição à tese do departamento de São Paulo ao IV CBA — TEMA 4: a industria e o ambiente de trabalho - algumas características fundamentais da industrialização no Brasil. In Congresso Brasileiro de Arquitetos. 6º 1966. Anais. Salvador: IAB, 1966.

Noticiário da Coordenação Modular. São Paulo, CBC-Bouwcentrum, ago de 1970, número 9.

NOVAIS, F. A.; SCHWARCZ, L. M. (org). História da vida privada no Brasil. São Paulo, Cia das Letras, 1998.

Volume 4: Contrastes da intimidade contemporânea; organizado por Lilia Moritz Schwarcz.

OCKMAN, Joan (org.). Architecture Culture 1943-1968. A documentary anthology. Nova Iorque: Rizzoli, 1993.

OLIVERI, G. Mário. Prefabbricazione o metaprogetto edilizio. Milano: Etas Kompass, 1968.

PEREIRA, Juliano Aparecido. Desenho Industrial e Arquitetura no ensino da FAUUSP (1948-1968). Tese de doutorado. São Carlos: EESG - USP, 2009.

PEREIRA, Sabrina Souza Bom; GUERRA, Abilio. Rodolpho Ortenblad Filho. A arquitetura moderna paulista olhando para Wright e Neutra. Entrevista, São Paulo, ano 12, n. 048.01, Vitruvius, out. 2011. ISSN 2175-6708. Disponível em <http://www.vitruvius.com.br/revistas/read/entrevista/11.048/4083>. Acesso em 10 de agosto de 2015 .

PICARELLI, Marlene. Sequência de Desenho Industrial. Coordenação Modular T4, $2^{\circ}$ ano de 1968. São Paulo, FAUUSP, 1968. Mimeo.

Procedimientos Raymond Camus. 200.000 mil alojamientos terminados en el mundo, 23 fabricas trabajando en 10 paises. S.l.: S.N.,1971.

ROSS, Norman (org). Guide to Architectural Trade Catalogues from Avery Library, Columbia University. Introduction by Frank Matero. Frederick: UPA Academic Editions, 1989. Acessado em 09 de outubro de 2015. Disponível em 
http://cisupa.proquest.com/ksc_assets/catalog/846.pdf).

ROSSO, Teodoro. Pré-fabricação, a coordenação modular teoria e prática. São Paulo, Instituto de Engenharia, 1966. Proposta o serviço de teto e métodos artesanais e métodos industriais. São Paulo, FAU, 19-?. Racionalização da construção. São Paulo, FAU/USP, 1980. 300 f. Teoria e prática da coordenação modular. São Paulo, FAU, 1976.

RUBINO, Silvana; GRINOVER, Marina (orgs). Lina por escrito: textos escolhidos de Lina Bo Bardi. São Paulo, Cosac\&Naif, 2009.

RUBINO, Silvana. A escrita de uma arquiteta. IN RUBINO, Silvana; GRINOVER, Marina (orgs). Lina por escrito. Textos escolhidos de Lina Bo Bardi. São Paulo, Cosac\&Naif, 2009.

SANT'ANNA Jr, Antonio Carlos. Subdesenvolvimento: urbanização e industrialização da construção. TGI FAUUSP. São Paulo, 1974. Orientação de Paulo J.V. Bruna.

SÃO PAULO (Estado) Lei n. 104, de 21 de junho de 1948. Cria a Faculdade de Arquitetura e Urbanismo, da Universidade de São Paulo, e dá outras providências.

SÃO PAULO (Estado). Lei n. 3.233, de 27 de outubro de 1955, que dispões sobre o regulamento da Faculdade de Arquitetura e Urbanismo, da Universidade de São Paulo, criada pela Lei n. 104, de 21 de junho de 1948, e dá outras providências.

SARAIVA, Pedro Paulo de Mello. Entrevista de Pedro Paulo de Mello Saraiva In GFAU. Corredor das humanas. São Paulo: GFAU/FAUUSP, 2009.

SEVERO, Leandro. Uma breve história da luta da grande mídia contra os interesses nacionais. Agência Carta Maior. São Paulo, 16 de junho de 2013. Consultado em 31 ago 2014. Disponível em http://cartamaior.com.br/?/Editoria/Politica/Uma-breve-historia-da-luta-da-grande-midia-contra-osinteresses-nacionais/4/28103

SHANKEN, Andrew M. From the Gospel of Efficiency to Modernism: A History of Sweet's Catalogue, 19061947. Design Issues: Volume 21, n.02 pág. 28 - 47. Spring 2005. MIT. Acessado em 09 de outubro de 2015. Disponível em http://www.ced.berkeley.edu/downloads/pubs/faculty/shanken 2005 gospel-of-efficiency.pdf. SINOPSES: Memória. São Paulo: FAUUSP, Edição Especial, 1993. ISSN: 0101-7225.

SINOPSES. São Paulo: FAUUSP, 1987. ISSN: 0101-7225.

SIQUEIRA, Renata Monteiro de. A inserção da FAUUSP no campo de arquitetura e urbanismo em São Paulo: as contribuições de Anhaia Mello e Vilanova Artigas. Dissertação de mestrado. São Paulo: FAUUSP, 2015. Orientação de Ana Cláudia Castilho Barone.

SIQUEIRA, Renata Monteiro; BRAGA, Marcos da Costa. FAU-USP, 1962: a implementação do Grupo de Disciplinas de Desenho Industrial no curso de Arquitetura e Urbanismo. In Congresso Internacional de Pesquisa em Design - CIPED, 5o. Anais em meio digital do 5o Congresso Internacional de Pesquisa em Design - CIPED. Bauru: UNESP, 2009 . 
SODRÉ, João Clark de Abreu. Arquitetura e viagens de formação pelo Brasil, 1938-1962. Dissertação de Mestrado. São Paulo, FAUUSP, 2010. Orientação Júlio Roberto Katinsky.

SOUZA, Abelardo Riedy de; TIBAU, Roberto José Goulart; CAMPOS FILHO, Cândido Malta. Sequência de Projeto: unidade de ensino alternativo do $4^{\circ}$ ano, $2^{\circ}$ semestre de 1968. São Paulo, FAUUSP, 1968. Mimeo.

SOUZA, Abelardo Riedy. Arquitetura no Brasil - depoimentos. São Paulo: Diadorim/Edusp, 1978.

SOUZA, Sérgio Renato Monteiro de. A posição do arquiteto na industrialização da construção civil. TGI FAUUSP. São Paulo, 1972. Orientação de Abelardo Gomes de Abreu.

SWEET'S indexed catalogue of building construction for the year 1906. New York City: The Architectural Record Co, 1906. With an introduction by Thomas Nolan, F.A.I.A - University of Pennsylvania. Disponível em https://ia800304.us.archive.org/10/items/architecturalcat1906swee/architecturalcat1906swee.pdf

TROYKO, Gyorgy. O problema da Habitação Popular em São Paulo. TGI FAUUSP. São Paulo, 1969. Orientação não indicada.

VASCONCELOS, Augusto Carlos de. O concreto no Brasil. São Paulo: Studio Nobel, 2002.

XAVIER, Alberto. Depoimento de uma geração: arquitetura moderna brasileira. Organizado por Alberto Fernando Melchiades Xavier. Prefácio de Julio Katinsky. São Paulo : Cosac \& Naify, 2003.

ZANETTINI, Siegbert et alli. Departamento de Projeto — Proposta de programação didática e de pesquisa. São Paulo, FAUUSP, 1970. Mimeo.

\section{Revista Acrópole}

$5^{\circ}$ Congresso Brasileiro de Arquitetos — Regulamento. Habitat. São Paulo, n. 42, p. 59, jun. 1957

Acrópole. São Paulo, n. 369/370, jan-fev 1970. Edição especial sobre a Universidade de Brasília.

Arquitetura industrial. Acrópole. São Paulo, n. 218, dez. 1956.

ARTIGAS, J.B.V; PENTEADO, F; ROCHA, P.A.M; MARTINO, A.A; VISCONTI, M.G.G; NUNES, R;

GAMA, R. Conjunto habitacional em Cumbica. Acrópole. São Paulo, n. 372, p. 32-37, abr. 1970.

Blocos de concreto "sistema trillor”. Acrópole. São Paulo, n. 209, p. 212, fev. 1956

BRATKE, Oswaldo Arthur. Habitações populares. Acrópole. São Paulo, n. 335, p. 24-27, dez. 1966.

BRUNA, PauloJ.V. Subsídios para uma política de industrialização da construção no Brasil. Acrópole. São Paulo, n. 380, p. 32-37, dez. 1970.

Catálogo Brasileiro da Construção. Acrópole. São Paulo, n. 306, mai. 1964. Notas

CBC faz estudos para o BNH. Acrópole. São Paulo, n. 366, p. 11, out. 1969.

CBC faz estudos para o BNH. Acrópole. São Paulo, n. 366, p. 11, out. 1969.

Centro Brasileiro de Construção - Bouwcentrum. Acrópole. São Paulo, n. 350, p. 19, mai. 1968. 
Conclusões do Congresso de Lisboa - 1953 (continuação). Acrópole. São Paulo, n. 185-186, set./out. 1953. Boletim Mensal do IAB.

CORONA, Eduardo. Acerca da habitação popular. Acrópole. São Paulo, n. 319, p. 18, jul. 1965. Editorial.

CORONA, Eduardo. O conjunto habitacional de Cumbica. Acrópole. São Paulo, n. 348, p. 12, mar. 1968.

CORONA, Eduardo. Renovação do ensino de arquitetura. Acrópole. São Paulo, n. 350, p. 14, mai. 1968.

GORONA, Eduardo. Resultados do Fórum da FAU. Acrópole. São Paulo, n. 351, p. 10, jun. 1968.

CORONA, Eduardo. VII Congresso da União Internacional de Arquitetos. Acrópole. São Paulo, n. 291, fev. 1963.

COSTA, Flávio Dionysio de Andrade. Blocos de concreto vibrado. Acrópole. São Paulo, n. 209, p. 196-197, fev. 1956 ;

Editorial. Acrópole. São Paulo, n. 209, fev. 1956.

Editorial. Acrópole. São Paulo, n. 212, p. 01, mai. 1956.

Elementos vazados de concreto. Acrópole. São Paulo, n. 209, p. 206-207, fev. 1956;

Encontro Nacional de Ensino de Arquitetura 1967. Acrópole. São Paulo, n. 345, p. 14, nov. 1967.

ESCOREL, Fernando J. Tubos de concreto. Acrópole. São Paulo, n. 209, p. 213-215, fev. 1956.

Estrutura em concreto armado pré-fabricado. Acrópole. São Paulo, n. 241, p. 26-27, nov. 1958.

Estruturas leves de concreto armado pré-fabricadas. Acrópole. São Paulo, n. 209, p. 200-201, fev. 1956;

Estudo teórico de lajes pré-fabricadas. Acrópole. São Paulo, n. 209, p. 204-205, fev. 1956;

Grupo técnico de habitação. Acrópole. São Paulo, n. 313, p. 17, jan. 1965. Notas.

Indústria e o Plano Habitacional. Acrópole. São Paulo, n. 350, p. 18, mai. 1968.

LOTUFO, Z; PINI, U; SGANZERLA, G; LOTUFO, V. Escola técnica federal de São Paulo. Acrópole. São Paulo, n. 363, p. 38-41, jul. 1969.

LUCULESGU, Constantino. Construções com concreto armado super-vibrado. Acrópole. São Paulo, n. 209, p. 210, fev. 1956

LUCULESCU, Constantino. Lajes nervuradas com elementos múltiplos. Acrópole. São Paulo, n. 209, p. 211, fev. 1956

MARCONDES, Ney; DE GENNARO, João. Arquitetura industrial. Acrópole. São Paulo, n. 212, p. 312-315, mai. 1956.

MARTINO, A.A; BERGAMIN, A; CASTRO, J.G.S; BRUNA, P; BUENO Filho, J; BIASI, A.M; TAALAT, A;

TAYATA, M.A. Acrópole. Concurso para secretaria de Agricultura - lo prêmio. São Paulo, n. 357, p. 18-21, dez. 1968.

MAZZOCCHI, Maurizio. A pré-fabricação nas construções industriais. Acrópole. São Paulo, n. 241, p. 25, nov. 
1958.

MAZZOCGHI, Maurizio. A prefabricação nas construções industriais. Acrópole. São Paulo, n. 241, p. 25, nov. 1958

Os blocos de concreto em São Paulo. Acrópole. São Paulo, n. 209, p. 202-203, fev. 1956;

Pavimentação articulada. Acrópole. São Paulo, n. 209, p. 208-209, fev. 1956;

Planejamento industrial. Acrópole. São Paulo, n. 332, p. 38-39, set. 1966.

Plano habitacional. Acrópole. São Paulo, n. 335, p. 19, dez. 1966. Notas.

Plano Nacional de Habitação. Acrópole. São Paulo, n. 305, p. 21, abr. 1964. Notas.

Plano Nacional de Habitação. Acrópole. São Paulo, n. 306, mai. 1964. Notas.

Problema da habitação no Brasil. Acrópole. São Paulo, n. 278, jan. 1962. Noticiário.

Residência Eternit. Acrópole. São Paulo, n. 332, p. 22-23, set. 1966. Planejamento industrial. Acrópole. São Paulo, n. 332, p. 38-39, set. 1966.

RIBEIRO, Paulo Antunes. Arquitetura industrial no Rio de Janeiro. Acrópole. São Paulo, n. 219, p. 83-85, jan. 1957.

ROCHA, Paulo Mendes da. Unidade de habitação pré-fabricada 1967. Acrópole. São Paulo, n. 343, p. 43-45, set. 1967.

Setor residencial da Cidade Universitária. Acrópole. São Paulo, n. 303, p. 93-101, fev. 1964

Símbolo da nova era industrial brasileira - 6 meses para levantar as estruturas da fábrica GE em Campinas. Acrópole. São Paulo, n. 280, mar. 1962.

Teoria modular. Acrópole. São Paulo, n. 350, p. 22-23, mai. 1968.

União Internacional de Arquitetos - Conclusões do Congresso de Lisboa, 1953. Acrópole. São Paulo, n. 185, set. 1953. Boletim Mensal do IAB.

VICARI, José Vicente. A pré-fabricação na arquitetura industrial. Acrópole. São Paulo, n. 212, p. 319-323, mai. 1956.

XAVIER, J.B.A; COSTA, L.C; CRESTANA, F.V. Pré-fabricação para edifícios escolares. Acrópole. São Paulo, n. 360, p. 30-33, abr. 1969.

ZELATI, Aldo Coti. A construção e a pré-fabricação. Acrópole. São Paulo, n. 209, p. 185, fev. 1956;

ZELATI, Aldo Coti. A construção e a pré-fabricação. Acrópole. São Paulo, n. 209, p. 185, fev. 1956.

ZELATI, Aldo Coti. Laje dupla em concreto. Acrópole. São Paulo, n. 209, p. 198-199, fev. 1956;

\section{Revista Habitat}

Ainda o Plano Nacional de Habitação. Habitat. São Paulo, n. 76, p. 12, mar-abr. 1964. Editorial 
Artezanato e indústria. Habitat. São Paulo, n. 9, p. 86-87, out-dez. 1952.

As lajes pré-fabricadas. Habitat. São Paulo, n. 29, p. 65, abr. 1956.

Branco e preto. Habitat. São Paulo, n. 9, p. 89, out-dez. 1952. Seção Alencastro.

Depoimento e peripécias em torno da arquitetura soviética. Habitat. São Paulo, n. 26, p, 45-46, jan. 1956. Seção Noticiário.

Desenho industrial. Habitat. São Paulo, n. 02, p. 94, mar. 1951. Seção Alencastro;

Escola de desenho industrial. Habitat. São Paulo, n. 72, p. 59-60, jun. 1963.

FERRAZ, Geraldo. Habitat inicia um levantamento sobre as condições do ensino universitário em exposições feitas pelos responsáveis das diversas cadeiras da FAU. Habitat. São Paulo, n. 26, p. 5, jan. 1956.

FONGARO, Carlo B. Ambiente. Habitat. São Paulo, n. 50, p. 30-33, set-out. 1958.

Habitat prossegue no levantamento sobre as condições de ensino universitário em exposições feitas pelos responsáveis das diversas cadeiras de FAU. Habitat. São Paulo, São Paulo, n. 27, p. 47, fev. 1956.

KULTERMANN, Udo. O clássico L. Mies van der Rohe e os “miesianos”. Habitat. São Paulo, n. 43, p. 17-26, jul-ago. 1957

LANG, Alberto. Blocos de concreto vibrado e casas modulares. Habitat. São Paulo, n. 65, set. 1961.

MAZZOCCHI, Maurício. A casa, sua construção e sua industrialização. Habitat. São Paulo, n. 29, p. 33-36, abr. 1956

Problema remoto: o da moda. Habitat. São Paulo, n. 9, p. 65, out-dez. 1952.

RUCHTI, Jacob. Instituto de Arte Contemporânea. Habitat. São Paulo, n. 03, p. 62-65, 1951.

SAMBONET, Luiza. Uma moda brasileira. Habitat. São Paulo, n. 9, p. 66-85, out-dez. 1952.

Sobre nova educação diante dos problemas da automatização. Habitat. São Paulo, n. 34, p. 60, set. 1956.

Uma indústria que acompanha o esforço criador da moderna arquitetura brasileira. Habitat. São Paulo, n. 37, p 88-90, dez. 1956.

\section{Revista O Dirigente Construtor}

"Bouwcentrum": esforço para aprimorar a construção. O Dirigente Construtor. São Paulo, v. 4, n. 9, p. 49-52, jul. 1968. Administração e Custos.

A Federação das Indústrias do Estado de São Paulo pretende constituir um centro de coordenação. O Dirigente Construtor. São Paulo, v. 2, n. 11, p. 61, set. 1966. Entidades e dirigentes.

A marcha do PNH. O Dirigente Construtor. São Paulo, v. 2, n. 12, p. 9, out. 1966. Editorial.

Argamassa armada: amplas possibilidades de uso. O Dirigente Construtor. São Paulo, v. 6, n. 04, p. 33-40, fev. 1970.

Técnicas e materiais. 
Arquitetura de interiores. O Dirigente Construtor. São Paulo, v. 2, n. 7, p. 33-59, mai. 1966. Caderno Especial.

Carteira de redesconto é a chave do plano. O Dirigente Construtor. São Paulo, v. 1, n. 3, p. 74, jan. 1965. Entrevista.

Casa de fibrocimento pode ser montada em 10 dias. O Dirigente Construtor. São Paulo, v. 1, n. 7, mai. 1965.

Técnicas e Materiais.

Casa mínima sai pronta da fábrica. O Dirigente Construtor. São Paulo, v. 1, n. 12, p. 47-53, out. 1965. Técnicas e Materiais.

Casa própria: existe um tripé na base do problema. O Dirigente Construtor. São Paulo, v. 4, n. 9, p. 70, jul. 1968. Entrevista.

Construir casas não resolve o problema habitacional. O Dirigente Construtor. São Paulo, v. 1, n. 4, p. 82, fev. 1965. Entrevista;

Dispersão das habitações compromete a periferia urbana. O Dirigente Construtor. São paulo, v. 1, n. 10, p. 84, ago. 1965. Entrevista.

Experiência estrangeira pode ajudar Plano de Habitação. O Dirigente Construtor. São Paulo, v. 1, n. 9, p. 74, jul. 1965. Entrevista.

Habitat '67: engenho, diversificação e custo elevado. O Dirigente Construtor. São Paulo, v. 4, n. 3, p. 16-20, jan. 1968. Projetos e Obras.

Julgamento do PNH. O Dirigente Construtor. São Paulo, v. 6, n. 11, p. 08, set. 1970. Notas.

Nota sobre processos de pré-fabricação patenteados. O dirigente construtor. São Paulo, v. 1, n.1, p. 67, nov. 1964. Atualidades Mundiais.

Painéis leves de concreto permitem montar uma casa em 8 horas. O Dirigente Construtor. São Paulo, v. 1, n. 10, p. 47-50, ago. 1965. Técnicas e Materiais.

Painel TIGRE hidráulico e elétrico (publicidade) em O Dirigente Construtor. São Paulo, v. 1, n. 12, p. 46, out. 1965. Pré-fabricação de canteiro: cada qual com seu sistema. O Dirigente Construtor. São Paulo, v. 4, n. 10, p. 37-42, ago. 1968. Técnicas e materiais.

Pré-fabricação pesada dá casa montada em cinco horas. O Dirigente Construtor. São Paulo, v. 3, n. 3, p. 22-26, jan. 1967. Técnicas e Materiais

Pré-fabricação total transforma conjunto Padre Anchieta em grande jogo de armar. O Dirigente Construtor. São Paulo, v. 2, n. 6, p. 12-19, abr. 1966. Projetos e Obras.

Pré-moldados de concreto compensam para estruturas em série. O dirigente construtor. São Paulo, v. 1, n.1, p. 46-52, nov. 1964. Técnicas e Materiais.

Pré-moldagem atende a uma nova arquitetura do ensino. O Dirigente Construtor. São Paulo, v. 5, n. 04, p. 23-27, fev. 1969. Técnicas e materiais.

Problemas da pré-fabricação. O Dirigente Construtor. São Paulo, v. 2, n. 9, p. 9, jul. 1966. Editorial. 
RECON: operação para financiar materiais de construção. O Dirigente Construtor. São Paulo, v. 5, n. 03, p. 79-80, jan. 1969. Administração e custos.

Técnicos propõem assessoria ao BNH. O Dirigente Construtor. São Paulo, v.1, n. 6, p. 86, abr. 1965. Entrevista Um ano e meio de atividades no Centro Brasileiro da Construção. O Dirigente Construtor. São Paulo, v. 6, n. 07, p. 126, mai. 1970. Entrevista

Um ano e meio de atividades no Centro Brasileiro da Construção. O Dirigente Construtor. São Paulo, v. 6, n. 07, p. 126, mai. 1970. Entrevista.

\section{Sítios online}

1. Sítio online da União Internacional dos Arquitetos. Seção com a listagem dos Congressos Internacionais havidos desde 1948: http://www.uia.archi/en/s-informer/congres/tous-lescongres\#.VsoET4SMQkg

2. Sítio online da Escola SENAI Orlando Laviero Ferraiuolo: http://construcaocivil.sp.senai.br/institucional/1578/0/historico.

3. Sítio online do CSTB. Currículo de Gerard Blachére. http://www.cstb.fr/archives/webzines/editions/webzine-du-4-juillet-2011 / gerard-blacherescientifique-du-batiment.html

4. Disponível em http://www.neorex.com.br/sobre-neorex . O sítio online, no entanto, não aponta datas.

5. Síto da Camargo Corrêa. História da REAGO: http://www.camargocorrea.com.br/grupo-camargocorrea/grupo/historia/historia-1960-1969.html

6. Sítio online do Sweet's Catalog http://sweets.construction.com

\section{Arquivo Documental Lina Bo Bardi, do Instituto Lina Bo e P.M. Bardi}

Documento 1.550.2: "FAUUSP/ Composição Decorativa/ Prof. Contratado: Antonio Paim Vieira/ Programa proposto para 1953"

Documento 1.550.3: "FAUUSP/ Cadeira n. 22 "Composição Decorativa"/ Programa proposto para o ano de $1956 "$

Documento 1.551.2: Anotações de aula

Documento 1.552.1: "Cadeira Composição Decorativa (5ªno)"

Documento 1.552.5: Fragmento do Diário Oficial de 12 de maio de 1955 sobre a contratação de Lina Bo Bardi na FAUUSP

Documento 1.553.1: Documento da Reitoria da Universidade de São Paulo sobre a contratação de Lina Bo Bardi na FAUUSP 
Documento 1.556.3: "FAUUSP / Total de havidas e frequentadas de 'Composiçao Decorativa' durante os meses de março, abril e maio"

Documento 1.557.1: "FAUUSP / Relação da aulas dadas durante o primeiro semestre (18 de maio a 15 de junho) pelo Prof. Achilina Bo Bardi”.

Documento 1.559.2: "FAUUSP / Constituição das bancas examinadoras / exames finais - 1955"

Documento 1.559.3: uma carta de 7 de dezembro de 1955, do Prof. Lysandro Mele Pereira da Silva ao corpo docente da FAUUSP.

Documento 1.560.1: Termo de contratação de Lina Bo pela USP, de abril de 1956. 
Gaspar, Natália Maria. O debate sobre a industrialização da arquitetura na FAUUSP durante as décadas de 1950 e 1960. São Paulo, 2016. 180 p. : il.

\section{ERRATA}

$\begin{array}{llll}\text { Pág. } & \text { Linha } & \text { Onde se lê } & \text { Leia-se } \\ 52 & 09 & \text { José Vicente Vicari } & \text { Bassano Vacarini }\end{array}$

\section{GOMPLEMENTO}

\section{Deixamos de apresentar a legenda para as tabelas apresentadas no Capítulo 2. Segue legenda abaixo:}

a) Indicação de João Augusto Breves Filho, conforme documentação localizada no Arquivo Histórico da Escola Politécnica.

b) Conforme documento n. 1.559.2 do Arquivo Documental Lina Bo Bardi, do Instituto Lina Bo e P.M. Bardi.

c) Conforme Sylvia Ficher, 2005.

d) Conforme Sítio Online do Itaú Cultural, a professora Vera Helena Amaral lecionou também Composição Decorativa até 1961. Disponível em http://www.itaucultural.org.br/aplicexternas/ enciclopedia IC/index.cfm?

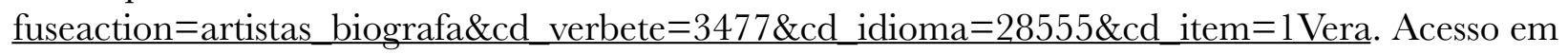
fevereiro de 2015.

e) Conforme currículo de Augusto Carlos de Vasconcelos. Disponível em http:// acvasconcelos.com.br/content/pdf/Augusto $\% 20$ Carlos $\% 20$ Vasconcelos $\% 20-\% 20 \mathrm{Curr}$ \%C3\%ADculo\%20Completo.pdf. Acesso em 26 de novembro de 2015.

f) Conforme Documento n. 1.559.1 do Arquivo Documental Lina Bo Bardi, do Instituto Lina Bo e P.M. Bardi; e conforme a lei de criação da FAUUSP. FONTE: SÃO PAULO (Estado) Lei n. 104, de 21 de junho de 1948. Cria a Faculdade de Arquitetura e Urbanismo, da Universidade de São Paulo, e dá outras providências.

g) Conforme o artigo da revista Habitat, Rino Levi e Roberto Cerqueira César, como assistente do primeiro, ministraram em 1955 a disciplina "Composições de Arquitetura — Grandes Composições”. FONTE: Habitat prossegue no levantamento sobre as condições de ensino universitário em exposições feitas pelos responsáveis das diversas cadeiras da FAU. Habitat. São Paulo, São Paulo, n. 27, p. 47, fev. 1956

h) Conforme depoimento de Paulo Bruna, o docente de 1956 a 1957 teria sido Pedro Moacyr do Amaral Cruz.

i) O nome do Professor Contratado Juarez Lopes Brandão estava escrito a mão no Programa de Disciplinas de 1962. 
j) Conforme Sérgio Matera (2006, p. 94), Carlos Millan lecionou na FAUUSP nos anos de 1959, até a data de seu falecimento. Conforme seu nome não é indicado ofcialmente na ementa da Cadeira 18, somente a do professor contratado, considerou-se que tivesse lecionado na FAUUSP na condição de assistente.

k) Conforme o artigo da revista Habitat, Rino Levi e Roberto Cerqueira César, como assistente do primeiro, ministraram em 1955 a disciplina "Composições de Arquitetura — Grandes

Composições". FONTE: Habitat prossegue no levantamento sobre as condições de ensino universitário em exposições feitas pelos responsáveis das diversas cadeiras da FAU. Habitat. São Paulo, São Paulo, n. 27, p. 47, fev. 1956

l) Para adaptação curricular, conforme aprovado no primeiro regimento da FAUUSP. FONTE: SÃO PAULO (Estado). Lei n. 3.233, de 27 de outubro de 1955, que dispões sobre o regulamento da Faculdade de Arquitetura e Urbanismo, da Universidade de São Paulo, criada pela Lei n. 104, de 21 de junho de 1948, e dá outras providências.

m) Os arquitetos Ariaki Kato e Roger Zmekhol estão indicados em ementa de disciplina (não transcrita) como instrutores da Cadeira 23. Não há indicação do ano em que assistiram o Prof. Roberto Cerqueira Cesar.

n) As notas " $n$ " foram dispostas de forma errada. Verificar a correção a seguir:

Pág. $61 \quad 1^{a}$ nota: Sobre M. Picarelli, conforme depoimento de Marlene Picarelli. $2^{\text {a }}$ nota: Possivelmente Eduardo Corona, conforme Souza, 1972. $3^{\text {a }}$ nota: Sobre J.R.G. Tibau, conforme depoimento de Marlene Picarelli.

Pág. $64 \quad 1^{a}$ nota: Sobre C. Fracarolli, conforme depoimento de Marlene Picarelli.

Pág. $67 \quad 1^{\text {a }}$ nota: Sobre Hélio Duarte, conforme depoimento de Marlene Picarelli. $2^{\text {a }}$ nota: Sobre Nestor Goulart R. Filho, conforme sua Livre Docência em 1964. $3^{\text {a }}$ nota: Sobre Miranda M.M. Magnoli, conforme depoimento de Paulo Bruna. $4^{a}$ nota: Sobre Composição Decorativa III, conforme documento 1.559.1 do Arquivo Documental Lina Bo Bardi, do Instituto Lina Bo e P.M. Bardi.

\section{Por erro de impressão, o seguinte trecho foi suprimido da página 64:}

Cadeira 18.

Composição decorativa
1956

$1957-61$ docente não indicado na ementa

José Maria Silva Neves 